\title{
Influenza bij ouderen : een onderzoek naar huisartsgeneeskundig belangrijke parameters voor de diagnostiek van en het vaccinatiebeleid bij influenza
}

Citation for published version (APA):

Govaert, T. M. E. (1994). Influenza bij ouderen : een onderzoek naar huisartsgeneeskundig belangrijke parameters voor de diagnostiek van en het vaccinatiebeleid bij influenza. [Doctoral Thesis, Maastricht University]. Rijksuniversiteit Limburg. https://doi.org/10.26481/dis.19940408tg

Document status and date:

Published: 01/01/1994

DOI:

10.26481/dis.19940408tg

Document Version:

Publisher's PDF, also known as Version of record

Please check the document version of this publication:

- A submitted manuscript is the version of the article upon submission and before peer-review. There can be important differences between the submitted version and the official published version of record.

People interested in the research are advised to contact the author for the final version of the publication, or visit the DOI to the publisher's website.

- The final author version and the galley proof are versions of the publication after peer review.

- The final published version features the final layout of the paper including the volume, issue and page numbers.

Link to publication

\footnotetext{
General rights rights.

- You may freely distribute the URL identifying the publication in the public portal. please follow below link for the End User Agreement:

www.umlib.nl/taverne-license

Take down policy

If you believe that this document breaches copyright please contact us at:

repository@maastrichtuniversity.nl

providing details and we will investigate your claim.
}

Copyright and moral rights for the publications made accessible in the public portal are retained by the authors and/or other copyright owners and it is a condition of accessing publications that users recognise and abide by the legal requirements associated with these

- Users may download and print one copy of any publication from the public portal for the purpose of private study or research.

- You may not further distribute the material or use it for any profit-making activity or commercial gain

If the publication is distributed under the terms of Article 25fa of the Dutch Copyright Act, indicated by the "Taverne" license above, 


\section{Influenza bij ouderen}




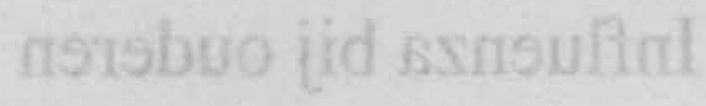




\section{Influenza bij ouderen}

Een onderzoek naar huisartsgeneeskundig belangrijke parameters voor de diagnostiek van en het vaccinatiebeleid bij influenza

\section{Proefschrift}

ter verkrijging van de graad van doctor aan de Rijksuniversiteit Limburg te Maastricht, op gezag van de Rector Magnificus, Prof. dr H. Philipsen, volgens het besluit van het college van Dekanen, in het openbaar te verdedigen op vrijdag 8 april 1994 om 16.00 uur

door

Theophile Maria Eduard Govaert 
Promotores:

Prof. dr J.A. Knottnerus

Prof. dr N. Masurel

Co-promotor:

Dr G.J. Dinant

Beoordelingscommissie:

Prof. dr E.F.M. Wouters (voorzitter)

Dr C.A.M.V.A. Bruggeman

Prof. dr E. van der Does

Prof. dr P.G. Knipschild

Prof. dr J.W. van Ree

Dit ondersoek werd mogelijk gemaakt door financiële steun van:

- het Praeventiefonds, projectmummer 28-2127

- Pharmachemic B.V. Haarlem

- de Limburgse Assurantie Service (LIASS)

- de Commissie veldintensief onderzoek van de Rijksuniversiteit Limburg (FdG, FdGW). 


\author{
"Volgens mij \\ is griep een zeer ernstige \\ ziekte, \\ maar de volksmond \\ pleegt dat te ontkennen \\ en spreekt van \\ 'een griepje'. \\ Ik kan niet begrijpen. \\ hoe zulk radbrakend gevaar. \\ dat het lichaam \\ van boven tot onder teistert, \\ met een verkleinw'oord \\ kan worden aangeduid"
}

Van Gennep

theoloog/ethicus

Aan Hanneke, voor jouw hulp

Voor mijn kinderen en kleinkind, als voorbeeld 


\section{Paranymfen:}

Drs H.J.L.M. Pieters

Drs M.J.P.M. Govaert 


\section{VOORWOORD}

Volgens het academisch statuut behoort een universitaire studie afgesloten te worden met een dissertatie. Na enkele eerdere pogingen werd mij in 1991 de mogelijkheid geboden een onderzoek te verrichten naar de effectiviteit van griepvaccinatie. Een onderzoek dat steeds boeiender werd naarmate ik mij er meer in kon verdiepen. De bevruchtende invloed van de samenwerking met de Rijksuniversiteit Limburg in de personen van Prof. dr J.A. Knottnerus, dr G.J. Dinant en dr C.T.M.C.N. Thijs, de hulp en ervaring van het Nationaal Influenza Centrum te Rotterdam in de personen van Prof. dr N. Masurel en dr M.J.W. Sprenger, het feit dat er meer tijd voor een dergelijk onderzoek beschikbaar kwam doordat alle kinderen "de deur uit waren", dat wil zeggen ingeschreven waren als student aan een universiteit, maar vooral het feit dat mijn vrouw even enthousiast was als ik en bereid was haar steentje dubbel en dwars bij te dragen, zorgden ervoor dat ik een ideale uitgangspositie had. 


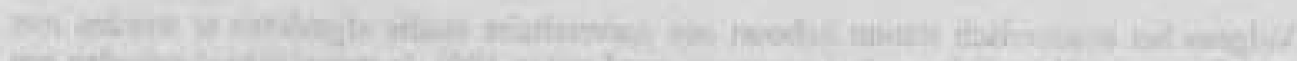

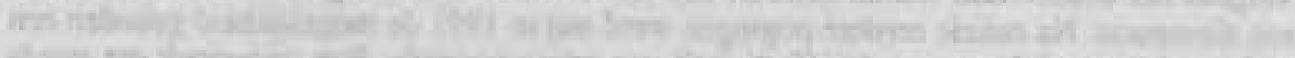

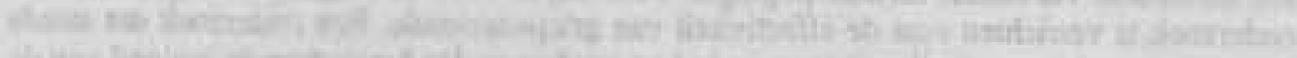

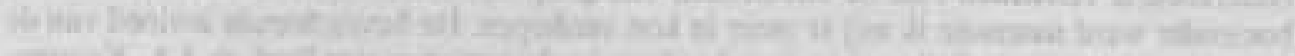

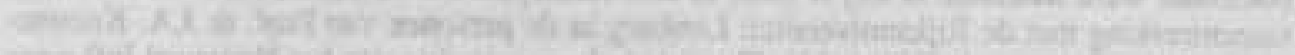

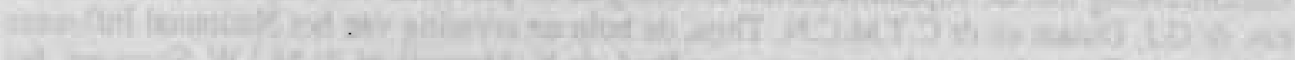

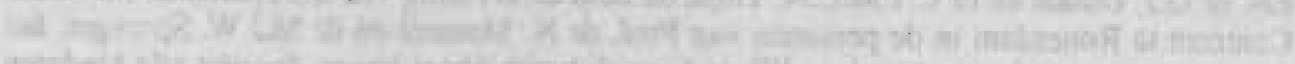

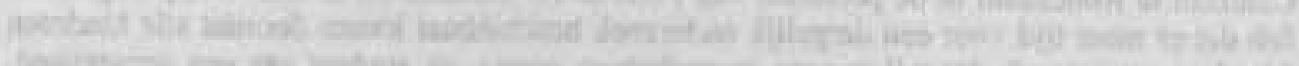

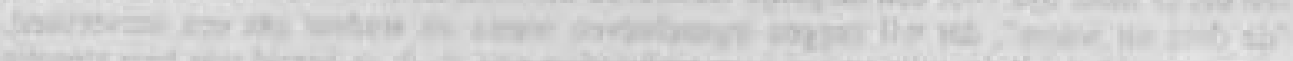

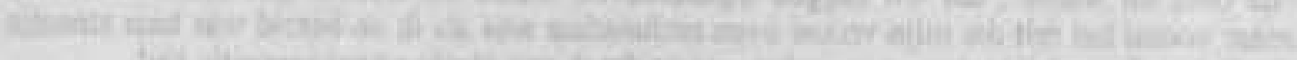

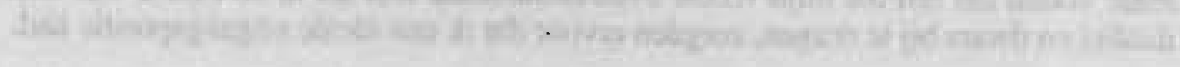




\section{INHOUD}

I ALGEMENE INTRODUCTIE

1 Inleiding 13

2 Historisch overzicht 17

II EXPLOREREND ONDERZOEK IN EIGEN PRAKTIJK 23

3 Incidentie van griep in een huisartspraktijk 25

4 Vaccinatie tegen influenza in een huisartspraktijk 33

III MULTI-CENTER ONDERZOEK

5 Algemene methodologie $\quad 45$

6 Algemene gegevens studiepopulatie $\quad 55$

7 De voorspellende waarde van de symptomatologie van influenza 63

8 De duur van influenza-achtige ziekten bij ouderen $\quad 73$

9 Bijwerkingen van influenzavaccinatie bij ouderen $\quad 83$

10 Immuunrespons op influenzavaccinatie bij ouderen 95

11 De effectiviteit van influenzavaccinatie bij ouderen 105

IV BESCHOUWING EN SAMENVATTING 121

12 Beschouwing 123

13 Samenvatting 127

14 Summary 131

15 Alfabetische literatuurlijst 135

BIJLAGEN 145

DANKWOORD 163

$\begin{array}{ll}\text { CURRICULUM VITAE } & 167\end{array}$ 
whingin

1

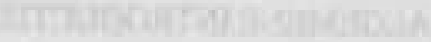

andiat at at

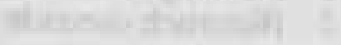

$+1$

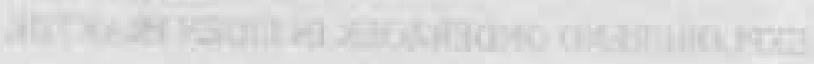

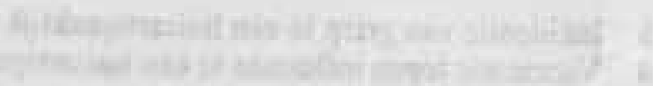

Ira

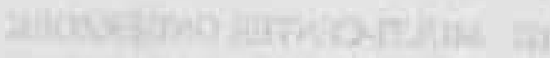

$+1$

W:

Fin

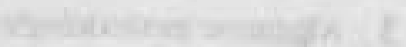

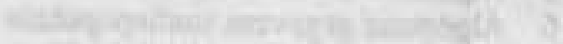

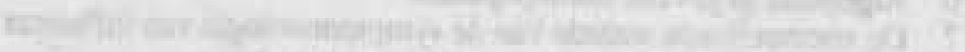

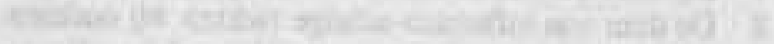

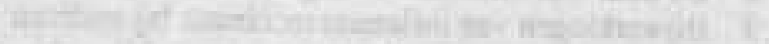

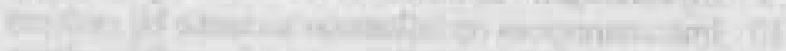

(1.)

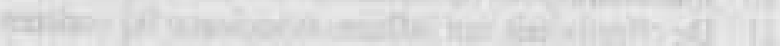

(4)

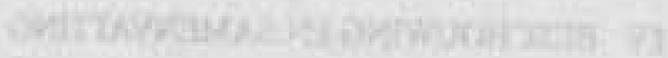

atis

and

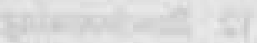

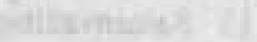

17:

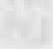

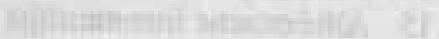

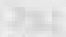

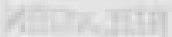

tat

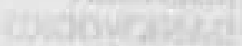

211

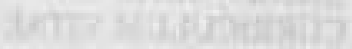




\section{DEEL I}

\section{ALGEMENE INTRODUCTIE}

1 Inleiding

2 Historisch overzicht 


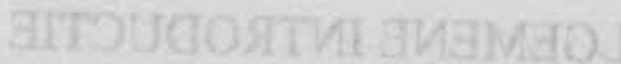

ginubistal Mfaists 20 ibsomaits 


\section{HOOFDSTUK 1}

\section{INLEIDING}

Jaarlijks sterven in Nederland direct of indirect tengevolge van influenza of influenzaachtige ziekten 2000 mensen (1). In de Verenigde Staten werden in totaal ongeveer 200.000 extra sterfgevallen toegeschreven aan influenza gedurende de 6 epidemieën in de jaren 1972-1981; in Engeland en Wales waren er dit ongeveer 120.000 gedurende de 10 winters van 1978-1988 (2-4). Vijfennegentig procent van deze sterfte valt in de leeftijdscategorie van 60 jaar en ouder (1-4). Een van de mogelijkheden om influenza en de gevolgen daarvan te voorkomen is vaccinatie. Er wordt echter getwijfeld aan het nuttig rendement van influenzavaccinatie. Hoewel de huisarts het meest geconfronteerd wordt met de directe gevolgen van influenza, is geschikte literatuur voor de dagelijkse praktijk van de huisarts weinig voorhanden. Verslagen bevatten veelal (te) gespecialiseerde informatie.

Daarnaast zijn studies naar de effectiviteit van influenzavaccinatie bij ouderen moeilijk uitvoerbaar, bijvoorbeeld omdat veel ouderen al gevaccineerd zijn en een wetenschappelijk gezien optimale studie op ethische bezwaren kan stuiten.

Dit proefschrift beschrijft een onderzoek naar de volgende vraagstellingen:

1 Wat is de incidentie van influenza?

2 Wat is de vaccinatiegraad met betrekking tot influenza in de huisartspraktijk?

3 Wat is de voorspellende waarde van het symptomencomplex waarop de diagnose influenza wordt gesteld?

4 Hoe lang is in het algemeen de ziekteduur ten gevolge van influenza?

5 Wat zijn de bijwerkingen van influenzavaccinatie?

6 Wat is de relatie tussen het niveau van antilichamen tegen influenza en het manifest worden van de ziekte?

7 Wat is het rendement van influenzavaccinatie in termen van immuunrespons en preventie van de ziekte?

Aangezien oudere mensen een hoger risico lopen op het krijgen van complicaties ten gevolge van influenza werd het onderzoek uitgevoerd in de doelgroep 60-jarigen en ouder. De reeds langer bestaande relatie met de vakgroep Huisartsgeneeskunde van de Rijksuniversiteit Limburg te Maastricht, de samenwerking met het Nationaal Influenza Centrum te Rotterdam en de bekendheid van de auteur, door zijn 31 jarige ervaring als huisarts, met vele praktijken in Zuid-Limburg, boden de mogelijkheid een onderzoek, waarin de genoemde vraagstellingen bestudeerd konden worden, uit te voeren. 
Er is getracht om huisartsen in Nederland een wetenschappelijk verantwoorde studie in een leesbare vorm aan te bieden. Dit heeft geleid tot de huidige vorm: een proefschrift samengesteld uit Nederlandstalige artikelen. Een voordeel van deze keuze is dat ieder hoofdstuk gelezen kan worden zonder de inhoud van de andere hoofdstukken bestudeerd te hebben. Het merendeel der artikelen is aangeboden, deels geaccepteerd en inmiddels gepubliceerd door Nederlandstalige en Engelstalige vakbladen.

Het proefschrift bestaat uit 3 delen.

Deel I omvat een algemene introductie waarin zijn opgenomen de inleiding (hoofdstuk 1) en een historisch overzicht (hoofdstuk 2). In het historisch overzicht worden de belangrijkste feiten inzake de geschiedenis van influenza-onderzoek chronologisch weergegeven.

Deel II omvat explorerend observationeel onderzoek verricht in de praktijk van de auteur. In het hoofdstuk "Incidentie van influenza en influenza-achtige ziekten (IAZ) in een huisartspraktijk" (hoofdstuk 3) wordt de incidentie van IAZ in deze praktijk vergeleken met de incidentie van IAZ zoals geregistreerd door de peilstations in Nederland. In het hoofdstuk "Opkomst en vaccinatiegraad van risicopatiënten" (hoofdstuk 4) wordt beschreven met welke benadering in de huisartspraktijk een hoge vaccinatiegraad van risicopatiënten bereikt kan worden.

Deel III omvat een multi-center onderzoek naar diagnostiek en ziekteduur van influenza, de effectiviteit van de vaccinatie en de bijwerkingen daarvan. Er vond, met medewerking van 34 huisartsen, een gerandomiseerd, dubbelblind, placebo-gecontroleerd onderzoek plaats. In de hoofdstukken 5 en 6 zijn de algemene methoden en de algemene gegevens van de studiepopulatie uitvoerig beschreven. Het is door de gekozen opbouw van het proefschrift niet te voorkomen dat delen hiervan in de volgende hoofdstukken terugkomen.

In hoofdstuk 7 wordt beschreven welk symptomencomplex de grootste voorspellende waarde heeft voor het stellen van de diagnose influenza. Daarbij wordt het in de dagelijkse praktijk moeilijk toepasbare serologisch onderzoek als "gouden standaard" gebruikt. In hoofdstuk 8 wordt nagegaan hoelang de ziekteduur is en of deze tengevolge van influenza of influenza-achtige ziekten bij ouderen anders is dan beschreven is voor de doorsnee bevolking. Tevens wordt nagegaan of bepaalde determinanten zoals vaccinatie- en risicostatus, alsmede geslacht en leeftijd van invloed zijn op de ziekteduur.

Een van de redenen waarom de vaccinatiegraad bij risicopatiënten nog steeds niet optimaal is betreft de vrees voor de injectie zelf en haar bijwerkingen. In hoofdstuk 9 wordt beschreven welke bijwerkingen in welke mate optreden bij vaccinatie. De hoofstukken 10 (Immuunrespons op influenzavaccinatie bij ouderen) en 11 (Effectiviteit van influenzavaccinatie bij ouderen) vullen elkaar aan. In deze hoofdstukken wordt een antwoord gegeven op de vraag in welke mate vaccinatie het optreden van influenza voorkomt. Men gaat gewoonlijk uit van de veronderstelling dat een goede immuunrespons op vaccinatie in een adequate afweer tegen influenza resulteert. Het optreden van klinische griepverschijnselen alsmede de in hoofdstuk 10 beschreven immunologische respons worden in hoofdstuk 11 gebruikt om het effect van vaccinatie tegen influenza in kaart te brengen.

Deel IV bevat de slotbeschouwing. Hierin worden de bevindingen uit de verschillende deelstudies in onderlinge samenhang nader bekeken. Daarnaast wordt ingegaan op de praktische problemen die zich bij een onderzoek als verricht kunnen voordoen. Tot slot volgen een Nederlandse en een Engelstalige samenvatting en een naar auteur gerangschikte lijst van de geraadpleegde literatuur. 


\section{LITERATUUR}

1 Sprenger MJW. The impact of influenza: an epidemiological study of morbidity, direct mortality and related mortality [Thesis]. Rotterdam: Erasmus Universiteit Rotterdam, 1990

2 Alling DW, Blackwelder WC, Stuart-Harris CH. A study of excess mortality during influenza epidemics in the United- States, 1968-1976. Am J Epidemiol 1981; 113: 30-43

3 Lui KJ, Kendal AP. Impact of influenza epidemics on mortality in the United States from October 1972 to May 1985. Am J Public Health 1987; 77: 712-16

4 Nicholson KG. Influenza vaccination and the elderly. $\mathrm{Br}$ med J 1990; 301: 617-18 


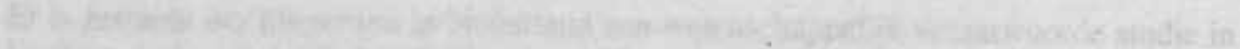

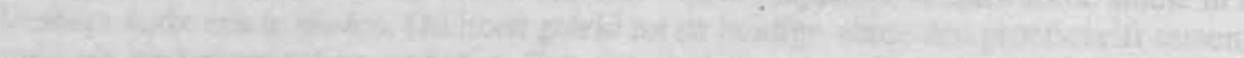

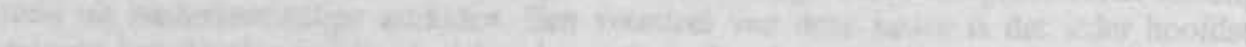

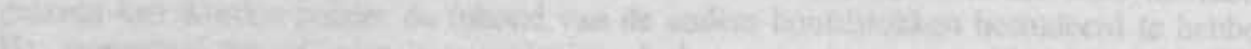

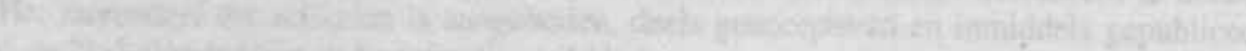

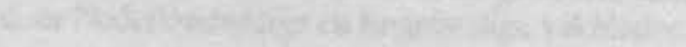

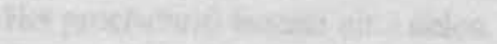

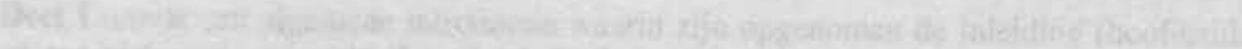

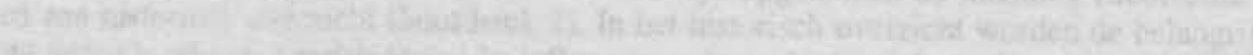

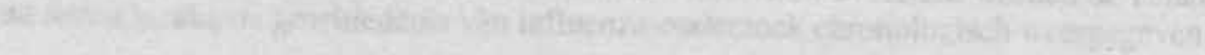

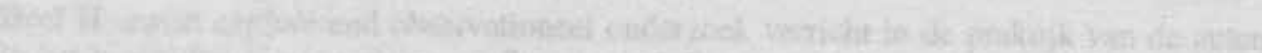

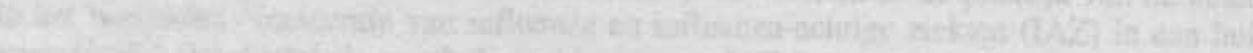

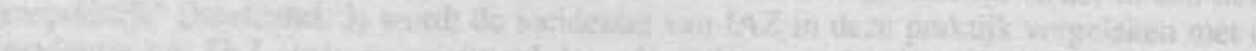

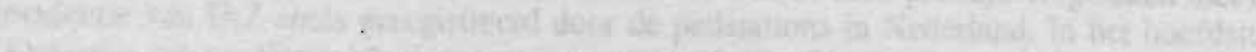
(3)

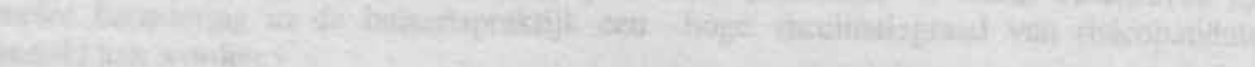

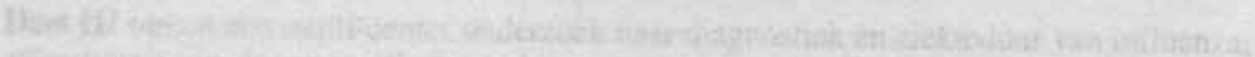

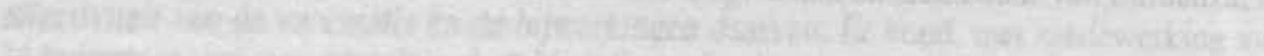

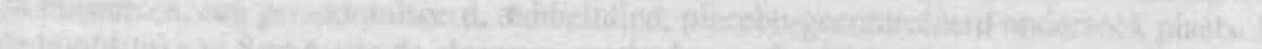

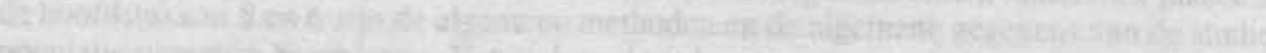

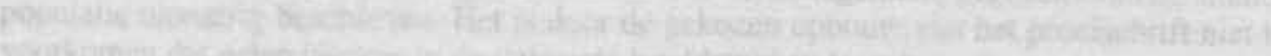

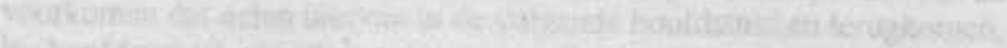

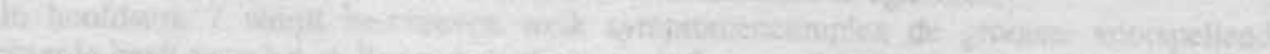

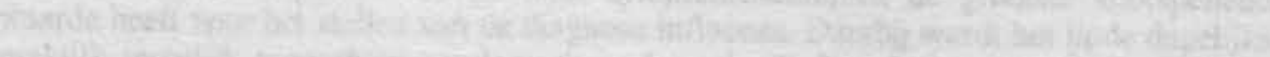

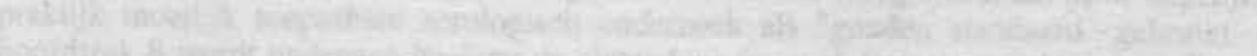

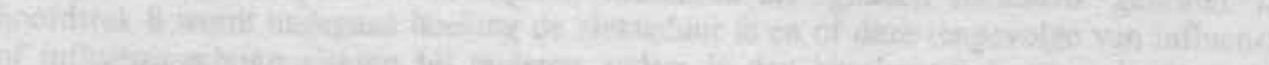

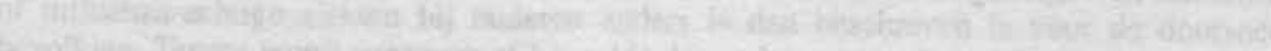

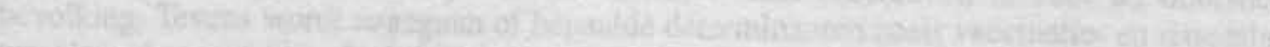

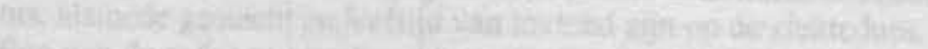

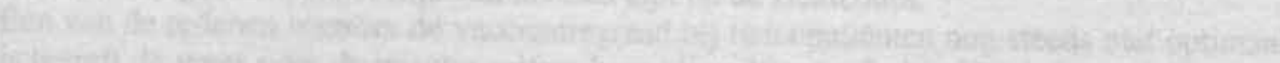

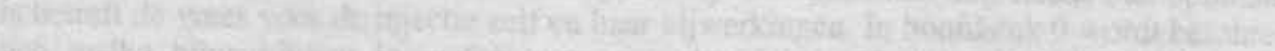

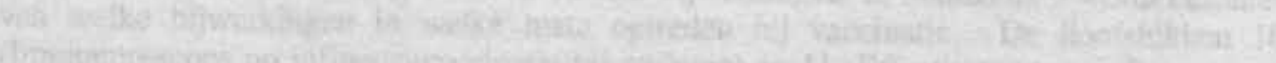

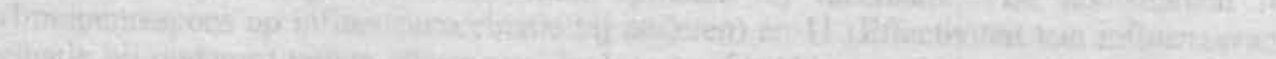

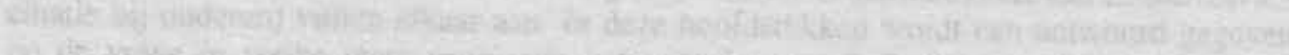

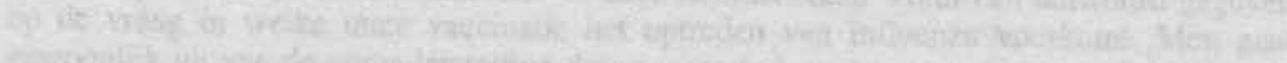

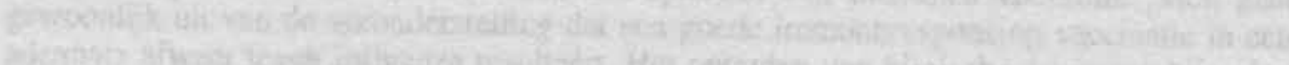

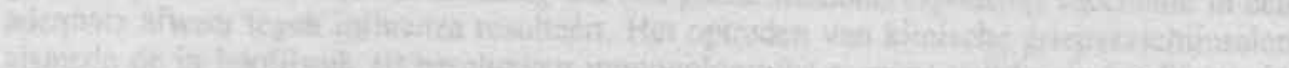
migavedy

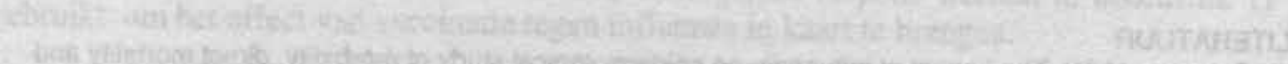

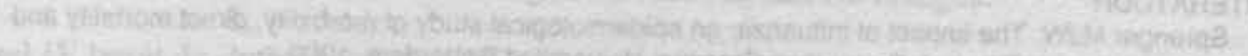

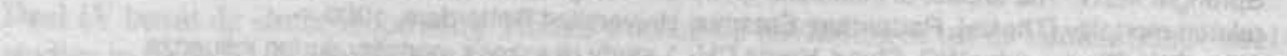

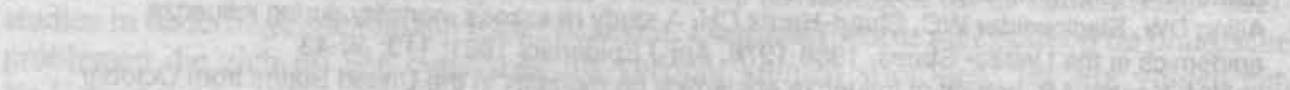

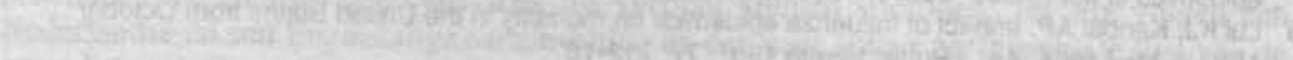

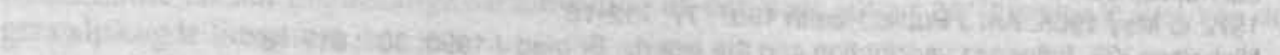




\section{HOOFDSTUK 2}

\section{HISTORISCH OVERZICHT}

\section{Epidemiologie}

In 1918 brak een pandemie van influenza uit, de zogenaamde "Spaanse griep". Deze werd zo genoemd omdat Spanje in die jaren geen oorlogscensuur kende -in tegenstelling tot de geallieerde landen, waar de epidemie al eerder rondwaarde- en aldus Spanje het eerste gewag maakte van de enorme omvang van deze pandemie. Binnen een half jaar stierven ruim 30 miljoen mensen hieraan (1). Uit verslagen van toenmalige kroniekschrijvers kan men opmaken dat reeds in de vroege middeleeuwen grote griepepidemieën voorkwamen (2). Bekend zijn de pandemieën van 1889-'90, de "Spaanse griep" van 1918-'19, de Aziatische pandemie die zich vanuit China in 1957-58 verspreidde en de Hong Kong epidemie in 1968-70. Epidemieën kunnen ontstaan door veranderingen in de antigene structuur van het virus. Verantwoordelijk voor de antigene structuur zijn glucoproteïne uitsteeksels, bestaande uit hemagglutinine of neuraminidase. Een kleine antigene verandering in het virus noemt men een antigene drift. Die treedt eens in de 2 a 3 jaar op. Grotere antigene veranderingen heten shift. Deze zijn verantwoordelijk voor epidemieën en treden om de 8 tot 12 jaar op. Meestal heeft er dan een verandering van de hemagglutininecomponent plaatsgevonden, soms van de neuraminidasecomponent. Een totaal andere antigene structuur krijgt het virus wanneer zowel de hemagglutinine- als de neuraminidasecomponent veranderen (bijvoorbeeld van H1N1 naar H2N2). Deze verandering treedt eens in de 30 tot 40 jaar op en is in het verleden verantwoordelijk geweest voor pandemieën.

\section{Morbiditeit en mortaliteit}

In 1847 publiceerde William Farr, directeur van de afdeling statistiek van het "General Register Office" in Engeland de eerste incidentiegegevens van influenza (tabel 2.1) (3).

Voor Farr was het toen al duidelijk dat veel doodsoorzaken, die werden toegeschreven aan bronchitis of pneumonie, in werkelijkheid op het conto van een hieraan ten grondslag liggende influenza-infectie kwamen. Het begrip "oversterfte", dat heden ten dage hiervoor gebruikt wordt, had hij toen al kunnen introduceren $(3,4)$.

Het duurde tot 1950 voordat in Atlanta de United States Centre for Disease Control (CDC) werd opgericht. Hierbij werd het begrip "surveillance" geintroduceerd, zijnde een samenstel van maatregelen om ziekten onder contrôle te krijgen (5). In 1968 werd dit begrip overgenomen door de World Health Organisation. Er ontstond een wereldwijd influenzaregistratienetwerk dat inmiddels ongeveer 120 stations omvat met centra in respectievelijk Atlanta en Londen en een coördinerend centrum te Genève (6-8). 
In Nederland wordt de incidentie van influenza geregistreerd door peilstations, een landelijk netwerk van huisartspraktijken dat $1 \%$ van de Nederlandse bevolking bestrijkt $(7,8)$. Door de peilstations werd van 1982 tot 1992 een gemiddelde jaarincidentie geregistreerd van 424 per 10.000, met een spreiding van 225 in 1990 tot 630 in 1986. De hoogste epidemische verheffing in deze periode vond plaats in het seizoen 1985-'86 met een weekincidentie van 71 per 10.000. In het seizoen 1987-'88 bleef een griepepidemie uit (hoogste weekincidentie 9 per 10.000 ).

De cumulatieve incidentie van influenza per jaar bedraagt 5-20\%, afhankelijk van de antigene structuur van het virus, de immuniteit van de bevolking en de incidentie (9). Voor de mortaliteit ten gevolge van influenza en aan influenza gerelateerde sterfgevallen worden, afhankelijk van de gebruikte studie- en classificatiemethode, verschillende resultaten gevonden $(4,10,11)$. Twee Nederlandse studies melden respectievelijk 750 en 2000 sterfgevallen per jaar $(4,11)$. Sterfte ten gevolge van influenza vindt in $95 \%$ der gevallen plaats bij patiënten van 60 jaar en ouder $(4,10)$.

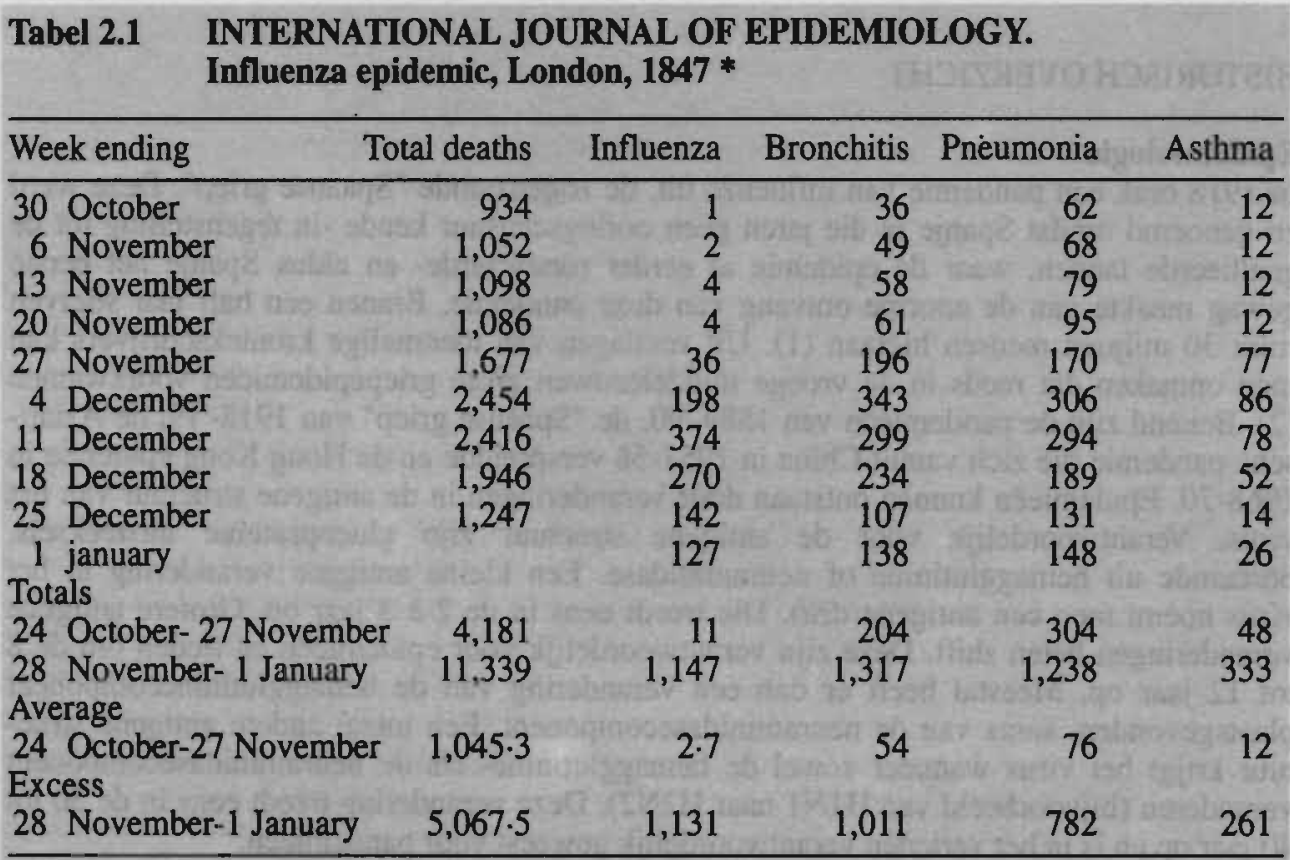

Total excess respiratory deaths $=3,185$

Total excess non-respiratory deaths $=1,8882.5$

* Reconstructed from Tenth Annual Report of the Registrar General

Overgenomen uit International Journal of Epidemiology 1976; 5: 16 (3)

\section{Ontdekking van het agens}

Pas in de vorige eeuw kwam men tot het inzicht dat influenza van mens op mens werd overgebracht. In Duitsland kon Richard Pfeiffer tijdens de influenza pandemie van 1889/'90 een bacterie uit het sputum van een "influenza"patient kweken. Hij achtte deze bacterie verantwoordelijk voor de infectie en noemde deze Hemophilus Influenzae. In 1933 slaagde Smith en zijn medewerkers er in fretten te besmetten met menselijk influenza materiaal (keelspoelsels). Men kon door middel van filtratie aantonen dat een virus het oorzakelijke agens was van influenza (12). Keelspoelsels van gezonde personen veroorzaakten geen influenza 
bij fretten. Reconvalescentie-serum van influenzapatiënten bevatte antilichamen welke het. virus van zieke fretten kon neutraliseren. Hierna ontwikkelde zich de kennis van influenza. in een snel tempo. Het virus werd geïsoleerd en vaccins werden bereid en beproefd $(13,14)$.

\section{Het virus}

Het influenzavirus behoort tot de orthomyxovirussen en bestaat uit een RNA-kern omgeven door een mantel van twee lagen, een binnenste proteïnemembraan en een buitenste lipidenschil (figuur 2.1). De RNA-kern en het binnenste proteïne- membraan bepalen het type virus: A, B of C $(9,15)$. Glucoproteïne uitsteeksels, die bestaan uit hemagglutinine en neuraminidase componenten, en verankerd liggen in de lipidenschil, zijn verantwoordelijk voor de antigene structuur van het virus. Het type A virus komt zowel bij de mens als bij dieren voor (varkens, paarden, vogels, eenden, kalkoenen en sternen) en vertoont de grootste antigene variatie. Type B is alleen pathogeen voor de mens. Type $\mathrm{C}$ wordt behalve bij de mens ook bij varkens aangetroffen. Het vertoont de minste antigene variatie en veroorzaakt onschuldige luchtweginfecties bij kinderen.

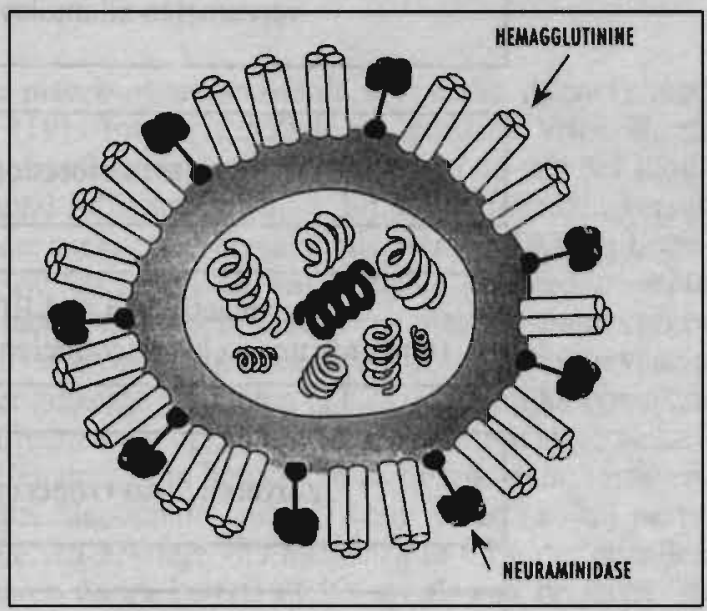

Figuur 2.1 Schematische voorstelling van het influenza-A virus (Bron: Fields BN. Virology. Raven Press, New York 1985).

A-virussen geïsoleerd bij het dier bezit-

ten eveneens hemagglutinine- en neuraminidase-antigenen, vaak identiek aan de antigene structuur van het menselijk virus. Op deze wijze kunnen influenza-epizoönosen de mens besmetten. De nomenclatuur van de influenzavirussen bevat ook gegevens over de plaats van isolatie, het stamnummer (volgorde van isolatie) en het jaar van isolatie. Bij A-virussen wordt tussen haakjes toegevoegd de antigene beschrijving van het hemagglutinine $(\mathrm{H})$ en de neuraminidase $(\mathrm{N})$. Zo werd de moleculair biologische analyse van het eerste Nederlandse isolaat van het seizoen 1992-'93 getypeerd als $\mathrm{A} / \mathrm{Ned} / 001 / 93$ ( $\mathrm{HIN} 1$ ), een stam nauw verwant met de reeds bekende stam $A / T a i w a n / 1 / 86(\mathrm{H} 1 N 1)$. Het eerste geïsoleerde Nederlandse influenza B-virus van dat seizoen werd voorlopig gekarakteriseerd als een B/Yamagata/16/88-achtige stam.

\section{Het vaccin}

Influenzavaccin werd tot 1970 bereid uit influenzavirus, geënt op bebroede kippeëieren. Het geïnactiveerde, zogenaamde whole virusvaccin bevatte veel proteïnen afkomstig van het kippeëi. Deze proteïnen werden verantwoordelijk geacht voor de vele, met name systemische bijwerkingen (16). Afhankelijk van het soort vaccin en de toedieningsvorm meldden diverse onderzoekers vaak hoge percentages bijwerkingen, zowel locale (tot $62 \%$ ) als systemische (tot $39 \%$ ). Door verbeterde

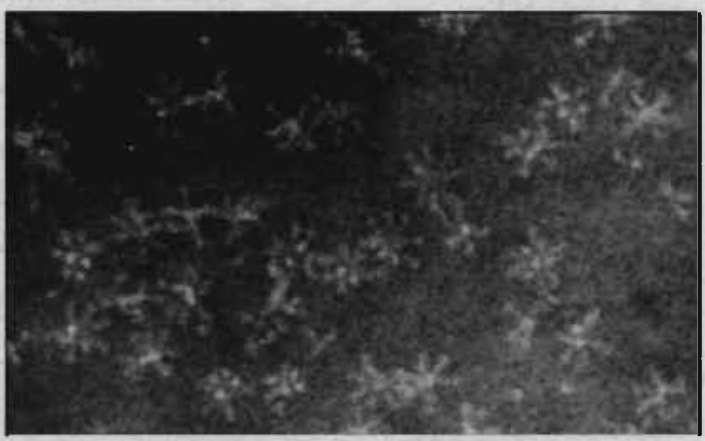

Foto van een gezuiverd split vaccin 400.000 maal vergroot (elecironenmicroscoop), afgegeven door I.G.S. Furminger, PhD FRSC, Technical Director MEDEVA, Engeland 


\section{Diagram: BEREIDING INFLUENZAVACCIN}

enten bebroede kippeëieren

verzamelen allantoisvloeistof

klaren vloeistof

inactiveren met BPL *

(binnen 6 uur na het verzarnelen van de vloeistof)

zuiveren virus (zonecentrifuge)

vanaf nu

geschiedt de

bereiding steriel

scheiden virusbestanddelen

(zonecentrifuge met behulp van Triton N 101) **

binden van Triton N 101 tot fosfaatzout

verwijderen fosfaatzout middels ultrafiltratie

0,2 u steriel filttraat

voorraad van één stam

samenstelling vaccin uit verschillende stammen

* BPL:B-proprionlacton ( $\mathrm{C} 2 \mathrm{H} 4 \mathrm{O} 2$ )

** Triton N 101; een poly-oxy-ethyleen ether

(C14H21. [O.CH2.CH2] n.OH 
isolatie technieken (sharples-centrifuge en zone-centrifuge) was men in staat zuiverder vaccins, waarin minder eiwitresten achterbleven, te produceren (17). Later zijn de split- en subunit-vaccins ontwikkeld (zie diagram) (18). Het split-vaccin is een "disrupted" vaccin (zie foto). De virus partikels zijn kleiner en veroorzaken daardoor minder bijwerkingen. Het subunit-vaccin bevat alleen de manteleiwitten. Van de op deze manier bereide vaccins werden in diverse publicaties minder bijwerkingen gemeld; locale van 3 tot $20 \%$, systemische van $0-5 \%(16,18)$.

\section{Effectiviteitstudies}

In 1943 werd in Amerika de eerste grote placebo-gecontroleerde veldstudie verricht naar de effectiviteit van het influenzavaccin (19). Totaal 12.500 jonge gezonde vrijwilligers namen deel aan dit onderzoek. De diagnose influenza werd gesteld op grond van het klinische beeld. De verhouding tussen het aantal influenza gevallen bij gevaccineerden versus niet gevaccineerden was 1 op 3. Een andere prospectieve veldstudie werd in 1952 in Engeland gedaan (20). Hierbij werd een nieuw vaccin getest ten opzichte van een contrôle vaccin. Er werd een $40 \%$ reductie van influenza gevonden in de groep met het studie vaccin gevaccineerden $(n=6340)$ ten opzichte van de groep gevaccineerden met het contrôle vaccin $(\mathrm{n}=6370)$. Andere studies meldden minder gunstige resultaten $(21,22)$. Mogelijke oorzaken hiervan zijn een te lage incidentie van influenza ten opzichte van influenza-achtige ziektebeelden, matige overeenkomst tussen virusstammen in het vaccin en circulerende virussen, dan wel een te kleine onderzoekpopulatie. Genoemde studies werden verricht bij jonge gezonde vrijwilligers. Aangezien de sterfte ten gevolge van influenza in $95 \%$ der gevallen patiënten in de leeftijdgroep van 60 jaar en ouder betreft $(4,10)$ werden in de jaren ' 80 enkele groots opgezette retrospectieve studies verricht naar de invloed van vaccinatie bij ouderen op ernstige morbiditeit en mortaliteit (23-25). Vaccinatie zou een reductie van ernstige morbiditeit van $72 \%$ en van mortaliteit van $87 \%$ opleveren (23). Serologische studies naar het effect van influenzavaccinatie bij ouderen werden weinig gevonden. Enkele prospectieve, deels gerandomiseerde, niet geblindeerde, studies meldden een gunstig effect van vaccinatie (26-28). 


\section{LITERATUUR}

1 Patterson KD, Pyle GF. The geography and mortality of the 1918 influenza pandemic. Bull Hist Med 1991; 65: 4-21

2 Vanghan WT. Influenza - an epidemiology study. Am J Hyg, Monograph 1921; 1: 1

3 Langmuir AD. William Farr: Founder of Modern Concepts of Surveillance. Int J Epidemiol 1976; 5: 13-18

4 Sprenger MJW. The impact of influenza: an epidemiological study of morbidity, direct mortality and related mortality [Thesis]. Rotterdarn: Erasmus Universiteit Rotterdam, 1990

5 Langmuir AD. Evolution of the concept of surveillance in the United States. Proc Roy Soc Med 1971; 64: $681-84$

6 Hannoun C, Dab W, Cohen JM. A new influenza surveillance system in France: the lle-de- France "Grog". 1. Principles and Methodology. Eur J Epidemiol 1989; 5: 285-93.

7 Nederlands Instituut voor onderzoek van de eerste lijns.- gezondheidszorg (NIVEL). Continue morbiditeits registratie peilstations Nederland. 1988/89. Utrecht: NIVEL; 1991

8 Collette HJA, Bijkerk H. Vijftien jaar peilstations Nederland, 1970-1984. Huisarts Wet 1985; 28:207-10.

9 Masurel N. Orthomyxoviridae in: Wilterdink JB. Medische virologie, Utrecht: Boon, Scheltema en Holkema, 1987

10 Alling DW, Blackwelder WC, Stuart-Harris $\mathrm{CH}$. A study of excess mortality during influenza epidemics in the United States, 1968-1976. Am J Epidemiol 1981; 113: 30-43

11 Meynaar IA, Wout JW van het, Vandenbroucke JP. Furth $R$ van. Vaccinatie tegen influenza: Aanmoedigen of ałzien? Ned Tijdschr Geneeskd 1992; 136: 168-72

12 Smith W, Andrewes CH, Laidlaw CH. A virus obtained from influenza patients. Lancet 1933; ii: 66-68

13 Henle W, Henle G, Stoke J. Demonstration of efficiency of vaccination against influenza type A by experimental infection of human beings. $\mathrm{J}$ Immun 1943; 46: 163-75

14 Salk JE. Reactions to concentrated influenza virus vaccines. J Immun 1948; 58: 269-95

15 Stuart-Harris $\mathrm{CH}$, Schild GC, Oxford JS. Influenza. The viruses and the disease, 2nd ed. London: Edward Arnold Ltd, 1985

16 Mostow SR, Schoenbaum SC, Dowdle WR, Coleman MT, Kaye HS. Studies with inactivated influenza vaccine purified by zonal centrifugation. I. Adverse reactions and serological response. Bull WHO 1969; 41: 525-30

17 Reimer CB. Comparison of techniques for influenza virus purification. J Bact 1966; 92: 1271-72

18 Ruben FL, Jackson GG. A new subunit influenza vaccine: acceptability compared with standard vaccines and effect of dose on antigenicity. J Infect Dis 1972; 125: 656-64

19 Members of the commission on influenza et al. A clinical evaluation of vaccination against influenza. JAMA 1944; 124: 982-85

20 Medical research council committee on influenza vaccine. Clinical trials of influenza vaccine. A progress report to the medical research council by its committee on clinical trials of influenza vaccine. Br Med J 1953; 267: 1173-77

21 Francis T Jr, Salk JE, Quilligan JJ Jr. Experience with vaccination against influenza in the spring of 1947. Am J Public Health 1947; 37: 1013-16

22 D'Alesso DJ, Cox PM, Dick EL. Failure of inactivated influenza vaccine to protect aged population. JAMA 1969; 210: 485-89

23 Barker WH, Mullooly JP. Influenza vaccination of elderly persons, reduction in pneumonia and influenza hospitalization and deaths. JAMA 1980; 244: 2547-49

24 Barker WH, Mullooly JP. Impact of epidemic type A influenza in a defined adult population. Am J Epidemiol 1980; 112: 798-811

25 Patriarca PA, Weber JA, Parker RA, Hall WN, Kendal AP, Bregman DJ, Schonberger LB. Efficacy of influenza vaccine in nursing homes, reduction in illness and complications during an influenza A (H3N2) epidemic. JAMA 1985; 253: 1136-39.

26 Gross PA, Quinnan GV, Rodstein M, LaMontagne JR, Kaslow RA, Saah AJ, et al. Associations of influenza immunization with reduction in mortality in an elderly population. A prospective study. Arch Intern Med 1988; 148: 562-65

27 Stuart WH, Dull HB, Newton LH, Mc'Queen JL, Schiff ER. Evaluation of monovalent influenza vaccine in a retirement community during the epidemic of 1965-1966. JAMA 1969; 209: 232-38

28 Schoenbaum SC, Mostow Sr, Coleman MT, Kaye HS. Studies with inactivated influenza vaccines purified by zonal centrifugation 2. Efficacy. Bull WHO 1969: 531-35 


\section{DEEL II}

\section{EXPLOREREND ONDERZOEK IN EIGEN PRAKTIJK}

3 Incidentie van griep in een huisartspraktijk

4 Vaccinatie tegen influenza in een huisartspraktijk 



\section{HOOFDSTUK 3}

\section{INCIDENTIE VAN GRIEP IN EEN HUISARTSPRAKTIJK}

Th.M.E. Govaert, G.J. Dinant, N. Masurel, J.A. Knottnerus,

Aangeboden 


\section{SAMENVATTING}

Incidentiecijfers van influenza en influenza-achtige ziektebeelden (IAZ) zijn niet eensluidend. Om de incidentie hiervan te kunnen schatten is aan het eind van het influenzaseizoen 1990/91 in een huisartspraktijk aan alle 5746 patiënten een vragenlijst gezonden. De cumulatieve incidentie van IAZ in de onderzochte praktijk bleek, afhankelijk van de gebruikte criteria (peilstations of International Classification of Health Problems in Primary Care (ICHPPC-2-defined) $614 / 10.000$ respectievelijk $856 / 10.000$ te zijn. De landelijke incidentie, opgegeven door de peilstations in Nederland, bedroeg in dezelfde periode 208/10.000. Wellicht berust het laatste cijfer op een onderrapportage.

Sleutelwoorden: huisartsgeneeskunde, influenza, incidentie. 


\section{INLEIDING}

Incidentiecijfers van influenza en influenza-achtige ziekte-beelden (IAZ) zijn niet eensluidend. Dit hangt af van de gebruikte diagnosecriteria, van het. aantal uren per week dat men registreert en van het soort contact (spreekuur, balie, telefoon) dat men vastlegt. Zo werd in Nederland in het Transitieproject in de registratieperiode van 18-03-1985 tot en met 31-081988 een jaarincidentie gemeten van 40 per 10.000 (1). Cijfers uit het Nederlands Instituut voor Onderzoek van de Eerste Lijn (NIVEL) gaven in de periode van 01-04-1987 tot en met 31-03-1988 een jaarincidentie van 250 per 10.000 (2). Door de peilstations werd in Nederland gedurende de jaren 1982 tot 1992 een gemiddelde jaarincidentie geregistreerd van 424 per 10.000 met een range van 225 in 1990 tot 630 in 1986 (3). De hoogste weekincidentie werd geregistreerd respectievelijk in de maanden december, januari en februari. Op basis van gegevens verstrekt door de peilstations was gedurende de afgelopen 10 jaar de hoogste epidemische verheffing in het seizoen 1985-'86, de laagste in het seizoen 1986-'87, terwijl in het seizoen 1987-'88 niet van een griepepidemie gesproken kon worden (weekincidenties respectievelijk 71, 26 en 9 per 10.000) (3).

De peilstations in Nederland bestaan uit een landelijk netwerk van huisartspraktijken, dat een procent van de Nederlandse bevolking bestrijkt $(3,4)$. Het aantal peilstations in 1989 bedroeg 45 . Hieraan namen 61 huisartsen deel. De nieuwe gevallen van IAZ worden met een weekstaat gemeld aan het NIVEL en via het NIVEL aan het Ministerie van WVC (3-5). De verzamelde gegevens worden vervolgens doorgegeven aan de Wereldgezondheidsorganisatie (WHO) en de Internationale Influenzacentra in Londen (UK) en Atlanta (USA). Gezien deze uiteenlopende incidentiecijfers hebben wij getracht door middel van een bevolkingsonderzoek, uitgevoerd in een huisartspraktijk, de incidentie van IAZ te bepalen, rekening houdend met storende factoren als verschillende diagnosecriteria, registratieperiodes en contactvormen. Dit was mede van belang ter voorbereiding van een effectiviteitsonderzoek, waarbij besloten moest worden of al dan niet kon worden volstaan met de aan de huisarts gemelde griepgevallen als effectmaat.

De vraagstelling van dit onderzoek luidt:

Wat is het verschil tussen de met de "sleepnet"-vragenlijst opgespoorde incidentie van IAZ en de landelijke cijfers van het influenzaseizoen?

Bovendien werden in de onderzoekperiode alle arts-patiëntcontacten in verband met IAZ geregistreerd om zodoende een indruk te verkrijgen van een eventuele onder- of overrapportage in deze praktijk.

\section{METHODE}

In een groepspraktijk met 5746 ingeschreven patiënten registreerden de huisartsen $(n=3)$ in de periode van 1 oktober 1990 tot 15 april 1991 alle patiënten die zich meldden met "griep". De diagnose IAZ werd gesteld op grond van de aanwezigheid van de volgende symptomen: acuut begin, hoesten, koude rillingen, koorts, algehele malaise, hoofdpijn, myalgie, rode of rauwe keel, rhinitis, contact met influenza. Hierbij werden de criteria van de peilstations respectievelijk de criteria volgens de International Classification of Health Problems in Primary Care (ICHPPC-2-defined) gebruikt (tabel 3.1)(4,6.7).

Op 15 april 1991 ontvingen de 2249 gezins- respectievelijk woonverbandhoofden uit de onderzochte praktijk een set vragenlijsten (bijlage 3.1) met het verzoek deze per gezinslid in te vullen (voor kinderen en bejaarden) of te laten invullen (door de andere gezins/woonverbandsleden) en binnen twee weken te retourneren indien men meende dat leden van het woonverband tussen 1 oktober 1990 en 15 april 1991 griep hadden doorgemaakt. De vragenlijsten bevatten items betreffende de criteria van IAZ, geformuleerd in begrijpelijke taal. Bij het invullen van deze lijsten kon de hulp van de praktijkassistente worden ingercepen. 


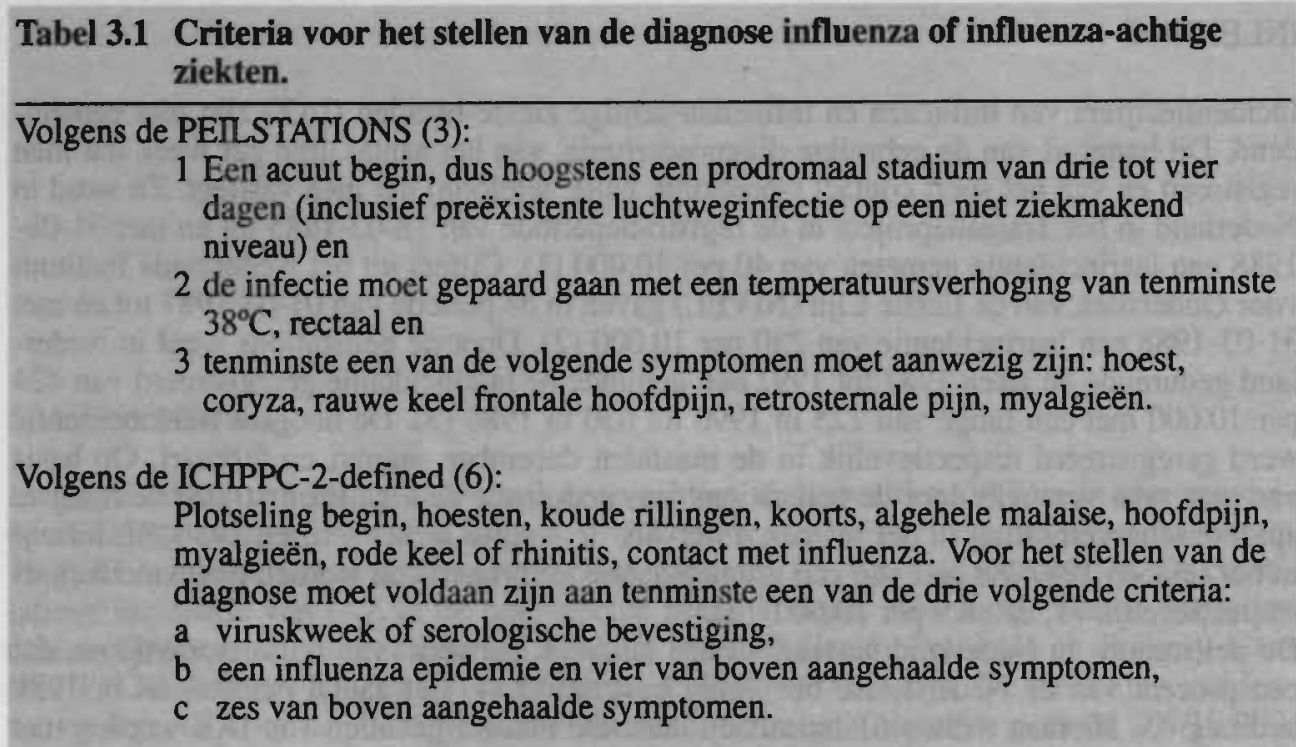

Met deze "sleepnetmethode" werd getracht retrospectief die gevallen van IAZ op te sporen die nog niet bekend waren bij de huisartsen.

Om de locale incidentie te kunnen vergelijken met de landelijke werd het locale incidentiecijfer vermenigvuldigd met $10.000 / 5746$. Het verschil tussen de locale en de landelijke incidentie (welke laatste ontleend werd aan de gegevens opgegeven door de Geneeskundige Hoofdinspectie van de Volksgezondheid) werd grafisch weergegeven. De analyses zijn gedaan met behulp van het BMDP statistisch software programma.

\section{RESULTATEN}

In de periode van 1 oktober 1990 tot 15 april 1991 werden 93 gevallen van IAZ door de huisarts geregistreerd (een incidentie van $93 \times 10.000 / 5746=162$ per 10.000 inwoners).

Door de gezins- respectievelijk woonverbandhoofden werden in de periode van 15 april 1991 tot 15 mei 19911800 (80\%) vragenlijsten geretourneerd. Daarvan konden 19 lijsten niet worden verwerkt wegens ontbrekende gegevens. In 353 en 492 gevallen werden IAZ gediagnostiseerd volgens respectievelijk de peilstation- en de ICHPPC-2-defined-criteria. Figuur 3.1 toont de incidentie van IAZ per registratieweek.

De locale incidentie in de onderzoekperiode (1 oktober 1990 tot 15 april 1991) bedroeg $614 / 10.000(353 \times 10.000 / 5746)$ en $856 / 10.000(492 \times 10.000 / 5746)$ bij gebruikmaking van respectievelijk de peilstation- en de ICHPPC-2- defined-criteria. De landelijke incidentie gemeten door de peilstations was over dezelfde periode aanzienlijk lager: 208/10.000.

\section{BESCHOUWING}

De incidentie van IAZ in de onderzochte praktijk was beduidend hoger in vergelijking met eerdere publicaties (1-3). Vergeleken met de landelijke cijfers (incidentie van 208/10.000 in de onderzoekperiode) waren de incidentiecijfers in deze praktijk voor dezelfde periode bijna drie- $(614 / 10.000)$ en vier- $(856 / 10.000)$ maal hoger, afhankelijk van de toegepaste diagnose criteria (peilstations respectievelijk ICHPPC-2-defined). Hiervoor is een aantal redenen aan te voeren. 


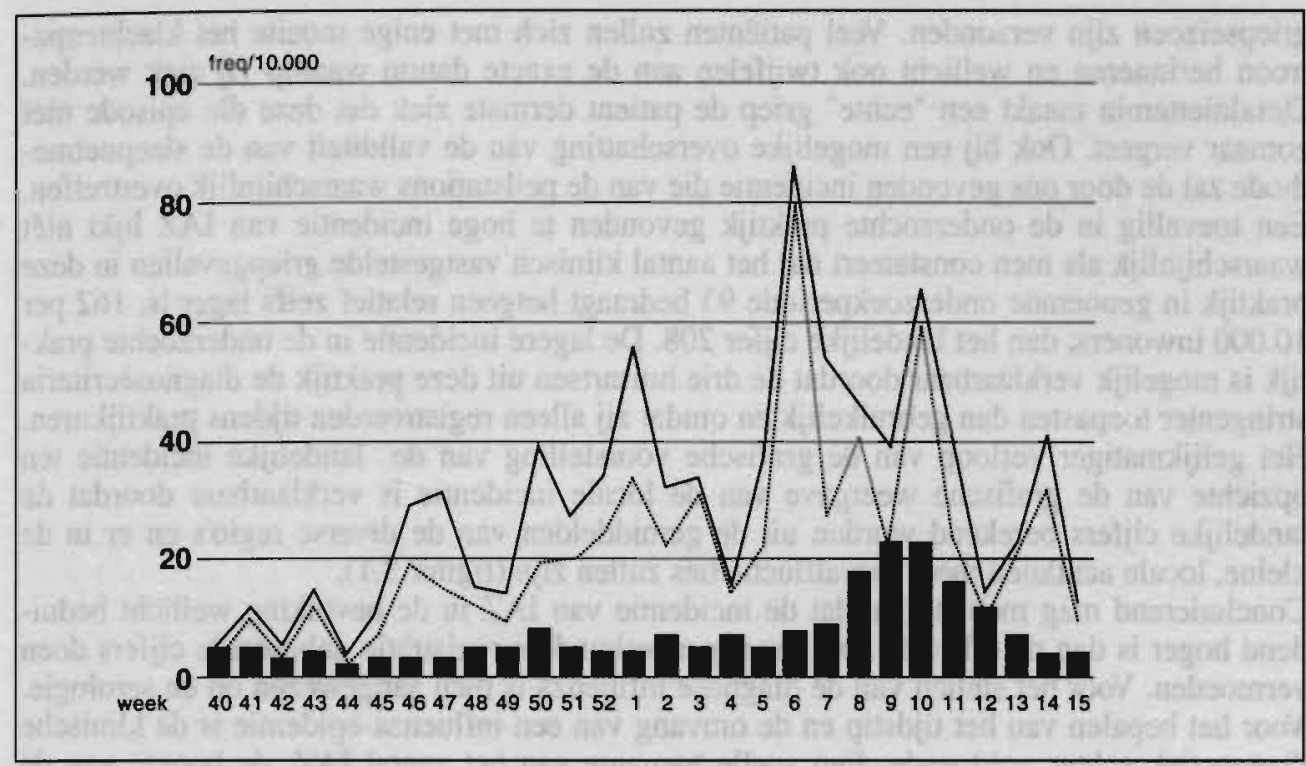

Figuur 3.1

Incidentiecijfers van 01-10-'90 tot 15-04-'91 volgens opgave van de peilstations in Nederland ( $\square$ ) en volgens locale opgave ( $\cdots$ berekend volgens criteria van de peilstations; - berekend volgens criteria van de ICHPPC-2-defined)

Vaak worden alleen arts-patiëntcontacten of arts-praktijkcontacten (inclusief assistente) geregistreerd. Telefonische contacten worden veelal niet genoteerd. Veel patiënten consulteren hun huisarts niet vanwege een IAZ (1-4).

Bovendien is er een verschil in de periode gedurende welke men registreert. Tijdens de weekenden vindt meestal geen registratie plaats. Ook tijdens avond- en wachtdiensten wordt vaak niet genoteerd. Een onderrapportage door de peilstations en de eigen huisarts zal zich gemakkelijk voordoen in drukke periodes, en is overigens alleen al om de reeds beschreven redenen (uitsluitend arts-patient contacten, registratie gedurende 5 dagen per week) onvolledig.

Ook is er divergentie in de toegepaste diagnosecriteria (tabel 3.1). Volgens de criteria van de peilstations behoort een acuut begin en temperatuur van tenminste $38^{\circ} \mathrm{Celsius,} \mathrm{rectaal}$ gemeten, obligaat aanwezig te zijn. Volgens de ICHPPC-2-defined- criteria is het, ook wanneer de koorts niet wordt geobjectiveerd en er geen acuut begin is, toch mogelijk op grond van de overige criteria de diagnose IAZ te stellen. Uit een enquête, in 1984, onder 102 huisartsen die deelnamen aan de influenzasurveillance in Engeland, kwam naar voren dat de symptomen koude rillingen, malaise, myalgieën en de aanwezigheid van een influenza-epidemie als belangrijkste criteria beschouwd werden voor het stellen van de diagnose influenza (8). In een Australisch onderzoek gedurende de jaren 1969, '70 en '72 constateerde men dat van de symptomen die in de ICHPPC-2-defined vermeld staan alleen de klacht hoesten bijna obligaat aanwezig was indien de diagnose serologisch bevestigd werd (9).

Tenslotte bestaat er een interdoktervariatie bij het interpreteren van de verschillende criteria. Om die reden wordt in Frankrijk aan registrerende artsen geadviseerd hun eigen criteria te gebruiken bij het stellen van de diagnose IAZ waarbij men dan wel consistent moet zijn in de toepassing hiervan (10).

Een vertekening van de door ons gevonden incidentie kan zijn ontstaan door onnauwkeurigheid bij het invullen van de vragenlijsten, omdat deze enquêtes pas aan het einde van het 
griepseizoen zijn verzonden. Veel patiënten zullen zich met enige moeite het klachtenpatroon herinneren en wellicht ook twijfelen aan de exacte datum waarop zij ziek werden. Desalniettemin maakt een "echte" griep de patient dermate ziek dat deze die episode niet zomaar vergeet. Ook bij een mogelijke overschatting van de validiteit van de sleepnetmethode zal de door ons gevonden incidentie die van de peilstations waarschijnlijk overtreffen. Een toevallig in de onderzochte praktijk gevonden te hoge incidentie van IAZ lijkt niet waarschijnlijk als men constateert dat het aantal klinisch vastgestelde griepgevallen in deze praktijk in genoemde onderzoekperiode 93 bedraagt hetgeen relatief zelfs lager is, 162 per 10.000 inwoners, dan het landelijke cijfer 208. De lagere incidentie in de onderzochte praktijk is mogelijk verklaarbaar doordat de drie huisartsen uit deze praktijk de diagnosecriteria stringenter toepasten dan gebruikelijk en omdat zij alleen registreerden tijdens praktijkuren. Het gelijkmatiger verloop van de grafische voorstelling van de landelijke incidentie ten opzichte van de grafische weergave van de locale incidentie is verklaarbaar doordat de landelijke cijfers berekend worden uit de gemiddelden van de diverse regio's en er in de kleine, locale aantallen meer toevalfluctuaties zullen zijn (figuur 3.1).

Concluderend mag men stellen dat de incidentie van IAZ in de bevolking wellicht beduidend hoger is dan de officiele op huisartsgeneeskundige registratie gebaseerde cijfers doen vermoeden. Voor het stellen van de diagnose influenza is men aangewezen op de serologie. Voor het bepalen van het tijdstip en de omvang van een influenza-epidemie is de klinische diagnostiek echter voldoende. Een snelle toename van het aantal IAZ, de hoogte van de incidentie en de periode waarover deze hogere incidentie zich voordoet zijn hierin maatgevend.

Indien wij in het kader van een gerandomiseerd experiment maximale informatie willen verkrijgen met betrekking tot de effectmaat "opgetreden griepgevallen", is het van groot belang naast de via het huisartsenspreekuur gemelde gevallen ook andere in de bevolking opgetreden griepgevallen op te sporen. 


\section{LITERATUUR}

1 Lamberts H, Brouwer HJ, Mohrs J. Reason for encounter \& episode \& proces oriented standard output from Transitions project. Part I. Amsterdam: University of Amsterdam, 1991

2 Velden J van den, Bakker DH de, Claessens AAMC, Schellevis FG. Een nationale studie naar ziekten en verrichtingen in de huisartspraktijk. Basisrapport: Morbiditeit in de huisartspraktijk. Utrecht: NIVEL, 1991

3 Nederlands instituut voor onderzoek van de eerste lijns- gezondheidszorg (NIVEL). Continue morbiditeits registratie peilstations Nederland. 1988/89. Utrecht: Nivel, 1991

4 Collette HJA, Bijkerk H. Vijttien jaar Peilstations Nederland, 1970-1984. Huisarts Wet 1985; 28: $207-10$

5 Sprenger MJW. The impact of influenza: an epidemiological study of morbidity, direct mortality and related mortality [Thesis]. Rotterdam: Erasmus Universiteit Rotterdam, 1990

6 Classification Committee of WONCA. ICHPPC-2-defined. Inclusion criteria for the use of the rubrics of the International Classification of Health Problems in Primary Care. Oxford: Oxford University Press, 1983

7 Lamberts H, Wood M. International Classification of Primary Care. Oxford: Oxford University Press, 1987

8 Fleming DM, Ayres JG. Diagnosis and patterns of incidence of influenza, influenza-like illnes and the common cold in general practic. J Roy Coll Gen Pract 1988; 38: 159-62

9 Gill PW, Murphy AM. The diagnosis of influenza. Aust Fam Phys 1991; 11: 1664-65

10 Hannoun C, Dab W, Cohen JM. A new influenza surveillance system in France: the lle-de- France "Grog". 1. Principles and Methodology. Eur J Epidemiol 1989; 5: 285-93 



\section{HOOFDSTUK 4}

\section{VACCINATIE TEGEN INFLUENZA IN EEN HUISARTSPRAKTIJK}

Opkomst en vaccinatiegraad van risicopatiënten

Th.M.E. Govaert, G.J. Dinant, J.A. Knottnerus

Huisarts Wet 1991; 34: 478-81 


\section{SAMENVATTING}

In een praktijk van 5500 patiënten werd prospectief geregistreerd hoeveel risicopatiënten volgens de richtlijnen van de Geneeskundige Hoofdinspectie van de Volksgezondheid- in 1990 werden gevaccineerd tegen influenza. Van de 574 opgeroepen patiënten behoorden er 309 tot een risicogroep. Van hen werden 288 patiënten gevaccineerd. Volgens Amerikaanse normen zouden 974 patiënten tot een risicogroep behoren. De opkomst ( 96 procent) en de vaccinatiegraad ( 93 procent) waren hoog, zeker in vergelijking met de uitkomsten van andere studies. Bovendien kan de vaccinatiegraad nog verbeterd worden door het toepassen van twee aanvullende zoekstrategieën: het geautomatiseerde huisarts-informatiesysteem (in dit geval Micro-His) en de patiëntengegevens van de locale apotheker. Gezien deze bevindingen moet het mogelijk zijn in Nederland een hoge vaccinatiegraad onder risicopatiënten voor influenza te bereiken.

Sleutelwoorden: huisartsgeneeskunde, influenza, vaccinatie. 


\section{INLEIDING}

Jaarlijks vinden in de meeste huisartspraktijken inentings-campagnes met het griepvaccin plaats. Het gaat hierbij primair om de risicogroepen die door de Geneeskundige Hoofdinspectie van de Volksgezondheid als zodanig worden aangemerkt (1). Er zijn echter ook patiënten die op eigen verzoek gevaccineerd worden.

Over de effecten van de vaccinatieprogramma's in de huisartspraktijk lijkt hoegenaamd niets bekend. Ook is niet duidelijk of vaccinatie het optreden van influenza voorkomt (2-5). Wel zou vaccinatie het aantal complicaties bij risicopatienten reduceren (6-9). Volgens de literatuur is de vaccinatiegraad laag; slechts een derde deel van de doelgroep wordt gevaccineerd $(5,10,11)$.

Ieder jaar geeft de Geneeskundige Hoofdinspectie aan hoe de risicogroepen zijn samengesteld. Volgens deze criteria zouden in de huisartspraktijk van Hofstra et al. $6,4 \%$ van de populatie behoren tot een risicogroep (11). In andere, met name Amerikaanse publicaties, wordt gesteld dat minstens $20 \%$ van de bevolking tot een risicogroep behoort $(5,9-14)$. Daar rekent men iedereen boven de 65 jaar tot een risicogroep $(6,8,9)$. Bovendien worden patiënten met lichte risico's, zoals een status na myocardinfarct zonder restverschijnselen, tot een risicogroep gerekend.

Veel onderzoek is verricht naar methoden om de vaccinatiegraad van risicopatiënten te verhogen (tabel 4.1). In de onderzochte praktijken bleek het opkomstpercentage van mensen behorende tot een risicogroep in de Verenigde Staten, Canada en het Verenigd Koninkrijk laag te zijn; $10-50 \%(2,13,15,16)$. Praktijken die een actief beleid voerden scoorden beter; een recente Nederlandse publicatie meldt een opkomstpercentage van $50 \%$ (11).

Tabel 4.1 Opkomstpercentages bij verschillende oproepsystemen.

\begin{tabular}{lrcccc}
\hline Referentienummer & Aantal & $\begin{array}{c}\text { Oproep via: } \\
\text { spreekuur }\end{array}$ & telefoon & brief & Geen oproep \\
\hline 1 & 133.760 & & & 30 & 8 \\
2 & 4.643 & & & 50 & \\
3 & 939 & 23 & 37 & 35 & 10 \\
4 & 787 & & 9 & 10 & 4 \\
5 & 273 & & 55 & 43 & 17 \\
\hline
\end{tabular}

1: Nicholson KG et al. Trent, Engeland; (2).

2: Hofstra $\mathrm{M}$ et al. Groningen; (11).

3: McDowell I et al. Ottawa, Canada; (13).

4: Brimberry R. Arkansas, Verenigde Staten (15).

5: Frank JW et al. Toronto, Canada; (16).

In de huisartspraktijk van de eerste auteur - 5500 patiënten; twee artsen full-time, eén arts part-time - wordt sinds 1962 gevaccineerd tegen influenza. Aanvankelijk werd de vaccinatie aangekondigd door middel van een affiche in de wachtkamer. Sinds 1980 krijgen de patiënten tevens een briefje met de mededeling op welke datum en tijdstip zij gevaccineerd kunnen worden en of de kosten van deze vaccinatie wel of niet vergoed worden.

De vraagstellingen van dit onderzoek luiden:

1 Hoe hoog is het opkomstpercentage (na oproep) in deze huisartspraktijk waar al jaren een vaccinatie programma bestaat?

2 Hoe hoog is de vaccinatiegraad bij risico-en niet risicopatiënten volgens Nederlandse en Amerikaanse normen? 
3 Op welke wijze en hoe effectief kan de risicogroep worden geactualiseerd met gebruikmaking van respectievelijk de kaartenbak van de huisarts, een geautomatiseerd bestand en het apothekersbestand.

\section{METHODE}

In oktober en november 1990 is prospectief geregistreerd hoeveel patiënten werden opgeroepen, wie van hen behoorde tot een risicogroep en hoeveel patiënten werden gevaccineerd. Om het totale aantal patiënten met een medische indicatie volgens Amerikaanse richtlijnen vast te stellen, zijn bovendien alle patiëntendossiers beoordeeld. Hierbij werd genoteerd hoeveel patiënten ten onrechte niet geregistreerd stonden als risicopatient.

Aangezien de medische verslaglegging grotendeels geautomatiseerd is (Micro-His), was het tevens mogelijk via een aantal ICPC-codes patiënten met een medische indicatie op te sporen (tabel 4.2a).

Bovendien werd medewerking verleend door de plaatselijke apotheker. Door in zijn bestand te zoeken naar patiënten die (combinaties van) bepaalde medicaties gebruikten, was het mogelijk om patiënten die tot een risicogroep behoorden, te selecteren. Zo werd bijvoorbeeld gezocht naar patiënten die insuline gebruikten, naar alle patiënten ouder dan twintig jaar die acetosal $80 \mathrm{mg}$ gebruikten, en naar patiënten die een combinatie van corticosteroïden en bètasympaticomimetica gebruikten.

Tabel 4.2a

Gebruikte ICPC codes voor het samenstellenvan de risicogroepen.
Tabel $4.2 b$

Niet gebruikte codes die in aanmerking kunnen komen voor het samenstellen van de risicogroepen

K 74 angina pectoris

K 75 acuut myocard infarct

D 81

K 71

K 76 andere chron.ischemische hartziekten

K 77 decompensatio cordis

K 78 boezemfibrilleren/fladderen

K 80 ectopische slagen

K 82 cor pulmonale

K 83 klepaandoening niet reumat.NAO

R 84 maligne neoplasma bronchus/long

$\mathrm{R} 85$ and. maligne neoplasma tr. resp.

R 91 chron. bronchitis/bronchiectasieën

R 95 emphyseem/COPD

R 96 astma

S 10 furunkel/carbunkel, cellulitis lok.

T 90 diabetes mellitus

U 88 glomerulonephritis, nefrose

U 99 andere nierziekten
$\mathrm{K} 73$

K 84

K 90

K 93

L 82

L 85

$\mathrm{N} 86$

N 87

N 99

R 70

$\mathrm{R} 82$

$\mathrm{R} 86$

R 89

R 99

S 99

T 85

T 86

T 99 aangeboren afw. tr. digestivus acuut rheuma/reumat. hartziekte aangeboren afw. tr. circulatorius andere hartziekten cerebrovasc. accid. (CVA) [ex.TIA] longembolie/longinfarct aangeboren afw. bewegingsapparaat verworven afwijking wervelkolom multipele sclerose parkinsonisme, ziekte van parkinson andere ziekten zenuwstelsels NEG tuberc. tr. resp. pleuritis benigne neoplasma tr. resp. aangeb. afw. tr.resp. andere ziekten tr. respiratorius andere ziekten huid/subcutis hyperthyreoïdie hypothereoïdie and. endo. ziekten 


\section{RESULTATEN}

1 In oktober 1990 werden 574 patiënten opgeroepen voor een griepvaccinatie, van wie er 33 patienten niet verschenen (tabel 4.3). Het opkomstpercentage van de opgeroepen 299 risicopatiënten (volgens Nederlandse normen) bedroeg 96 procent; 11 risicopatiënten waren niet komen opdagen. Bovendien waren 10 risicopatiënten niet opgeroepen omdat zij in het verleden te kennen hadden gegeven dat zij geen prijs stelden op vaccinatie. Van de in totaal 309 risicopatiënten in de

Tabel 4.3 Opkomstpercentages in 1990*.

Medische indicatie $(\mathrm{n}=299)$

Geen medische indicatie $(n=275) 92$

Totaal $(n=574)$

94

Alle opgekomen patiënten werden gevaccineerd.

Tabel 4.4 Vaccinatiepercentages van risicopatiënten in 1990 volgens Nederlandse (NL) en Amerikaanse (VS) criteria.

Medische indicatie

- NL $(n=309)$

93

- VS $(n=974)$ praktijk werden er dus 288 gevaccineerd (93 procent, tabel 4.4).

2 Uitgaande van de Amerikaanse normen, waarin alle patiënten van 65 jaar en ouder tot een risicogroep behoren, en in de leeftijdsgroep van 20-64 jaar ook de lichtere risico's (4-9), kwamen wij tot 974 patiënten met een medische indicatie:

- 718 patiënten van 65 jaar en ouder;

- 83 patiënten van $20-65$ jaar met een bekende indicatie;

- 173 "nieuw geïndiceerde" patiënten van 20-65 jaar.

Van deze 974 patiënten bleken 408 patiënten gevaccineerd: 288 reeds bekende risicopatiënten en 120 bejaarde patiënten die voorheen op eigen verzoek waren gevaccineerd.

3 Uit de dossiers waren 309 patiënten reeds bekend met een medische indicatie. Bij toepassing van de Amerikaanse normen - waarbij alleen op aandoening en niet op leeftijd werd geselecteerd - werden via de dossiers in totaal 286 nieuwe risicopatiënten opgespoord (tabel 4.5).

\section{Tabel 4.5 Resultaten verschillende zoeksystemen.}

\begin{tabular}{lccc}
\hline Risicopatiënten & \multicolumn{3}{c}{ Aantallen opgespoorde patiënten } \\
\cline { 2 - 4 } & Kaartenbak & Micro-His & Apotheek \\
\hline Reeds bekend (a) & 309 & 309 & 309 \\
Ontdekt na zoekactie (b) & 286 & 132 & 182 \\
Extra opbrengst & - & 12 & 30 \\
Niet ontdekt (c) & 42 & 196 & 146 \\
Totaal aantal (a+b+c) & 637 & 637 & 637 \\
Opgespoord, geen indicatie & 0 & 0 & 83 \\
Opsporingspercentage (\%) & & $69 \%$ & $77 \%$ \\
(a+b)/totaal x 100 & $93 \%$ & 2 & 5 \\
tijdsinvestering in uren (d) & 14 & & \\
tijdsinvestering per extra & & 0,9 & 1,6 \\
opgespoorde risicopatiënt & 2,9 & & \\
in minuten (b/d) & & & \\
\hline
\end{tabular}


Via het Micro-His zoeksysteem werden 441 ( 309 bekende en 132 nieuwe) patiënten gevonden. Van deze 132 nieuw gevonden patiënten waren er 12 tevoren niet bekend als behorende tot een risicogroep. Van deze 12 patiënten werden er 11 ook via de medicatiehistorie van de apotheek gevonden.

Met behulp van het zoeksysteem van de apotheker werden 574 potentiële risicopatiënten gevonden. Van hen behoorden 83 patiënten niet tot een risicogroep, zodat er 491 overbleven: 309 bekend en 182 nieuw. Van hen waren 30 patiënten nog niet bekend via de kaartenbakanalyse en het Micro-His-zoeksysteem.

Het Micro-His en de apotheekgegevens leverden tesamen 42 nieuwe risicopatiënten op. Kaartenbakanalyse $(309+286)$ en opsporing via Micro-His en apotheek (42) leverden een totaal van 637 risicopatiënten op, $11,6 \%$ van de praktijkpopulatie. Door de opbrengsten te delen op het totale aantal risicopatiënten en de uitkomst te vermenigvuldigen met 100 werd het opsporingspercentage berekend.

Er waren 14 uren nodig om de kaartenbakken nog eens kritisch door te nemen. Het vergelijken van de resultaten uit de kaartenbakanalyse met die van het geautomatiseerde zoeksysteem vergde twee uren. Voor vergelijking met de gegevens verkregen via de apotheker waren vijf uren nodig. Tot slot kon de tijdinvestering per extra opgespoorde risicopatiënt worden berekend (tabel 4.5).

\section{BESCHOUWING}

Het opkomstpercentage in de onderzochte praktijk is zeer hoog: 96 procent. Ook de vaccinatiegraad van de groep risicopatienten is hoog: 93 procent. Het Nederlandse gezondheidszorgsysteem impliceert een hechte relatie tussen huisarts en patiënt. Deze vertrouwensrelatie en het feit dat de huisarts meestal in zijn eigen praktijkpand vaccineert, bevorderen dat relatief veel patienten gehoor geven aan een oproep. Bovendien werkt het systeem van jaarlijkse oproepen bevorderlijk op het opkomstgedrag. In Amerika worden veel vaccinatie programma's georganiseerd door gezondheidscentra van een universiteit of door de Health Maintenance Organisations $(12,13,15-17)$. Het minder persoonlijke karakter van deze systemen zou mede debet kunnen zijn aan de matige opkomst aldaar.

Slechts een klein deel van de praktijkpopulatie stond geregistreerd als risicopatient: 5,6 procent. Dit cijfer komt ongeveer overeen met het percentage patiënten met een medische indicatie dat Hofstra et al. in hun praktijk vonden: 6,4 procent (11). Indien de Amerikaanse criteria (risicopatient of leeftijd) worden gehanteerd zou 17.7 procent van de praktiikpopulatie tot een risicogroep behoren. De leeftijdsgroep tot 20 jaar is daarbij buiten beschouwing gelaten; in de onderzochte praktijk ging het om slechts 4 patiënten. Volgens de Amerikaanse criteria is de vaccinatiegraad in de onderzochte praktijk slechts 42 procent. Hierbij moet wel bedacht worden dat een aanzienlijk deel van deze 974 patiënten niet was opgeroepen.

In veel praktijken worden niet alle risicopatiënten gevaccineerd. Sommige patiënten ontsnappen aan de aandacht van de huisarts (11), anderen reageren niet op een oproep $(2,12,13,15,16)$, en niet iedere huisarts is voldoende gemotiveerd om systernatisch te vaccineren $(2,7)$.

In de onderzochte praktijk geldt ten aanzien van de patiënten met een "nieuwe indicatie" dat het meestal om lichtere risico's ging, zoals een patiënt met CARA die de laatste 3 jaren geen medicatie heeft gehad, of een patiënt met emphyseem of een infarct zonder complicaties.

Het verdient aanbeveling een lijst van risicopatiënten op te stellen en de reeds aanwezige lijst nog eens kritisch te controleren. Omgerekend naar een normpraktijk vergelijkbaar met onze situatie betekent dit naar schatting een eenmalige tijdinvestering van ongeveer 7 uur. De onderzochte praktijk was echter geautomatiseerd, de probleemlijst van de groene kaart 
was goed bijgehouden en er bestond al een lijst van risicopatiënten. Dit resulteerde in een relatief geringe tijdinvestering.

De drie opzoeksystemen leidden tot verschillende uitkomsten. Dit is onder meer een gevolg van het feit dat via het Micro-His zoeksysteem alleen ICPC-codes werden gebruikt die zonder twijfel beantwoordden aan de richtlijnen van de Hoofdinspectie; codes die te grofmazig zijn voor een efficiënte identificatie, zijn weggelaten (tabel 4.2b). Zo vallen onder de code R99- andere ziekten van de tractus respiratorius- zowel neusstenose en polyposis nasi, als silicosis en pneumothorax. Bovendien was ten tijde van dit onderzoek pas 55 procent van de probleemlijsten volledig ingevoerd.

Dat het opzoeken van patiënten via de apotheker ten opzichte van de kaartenbak een lager aantal geïndiceerden opleverde, wordt verklaard door het feit dat niet alle patiënten van de onderzochte praktijk bij betrokken apotheker zijn ingeschreven. Bovendien hebben niet alle riscicopatiënten medicatie ontvangen. Via de apotheker zijn niettemin 41 nieuwe patiënten gevonden. Van deze groep hadden overigens 25 patiënten een hypo-of hyperthyreoïdiediagnose waarnaar in de andere twee zoeksystemen niet was gezocht. Postoperatieve antistollingsmedicatie en het gebruik van insuline bij zwangerschapsdiabetes verklaren dat 83 patiënten door de apotheker in eerste instantie zijn gemeld als potentiële risicopatiënt, maar dat later niet bleken te zijn.

Via de kaartenbakken is in de onderzochte praktijk 93 procent van het totaal aantal risicopatiënten opgespoord. De leeftijdsgrens van 65 jaar en ouder is bij deze telling nog buiten beschouwing gelaten. Via het Micro-His zoeksysteem werd 69 procent van het totaal aantal risicopatiënten gevonden. Indien de niet gebruikte ICPC-codes zodanig verfijnd worden, dat ook hierop zonder veel correcties achteraf geselecteerd kan worden en wanneer de probleemlijsten van de patiënten volledig zijn ingevoerd, zal de effectiviteit van het MicroHis-zoeksysteem de kaartenbakmethode overtreffen. Daarnaast is het interessant dat het zoeksysteem via de medische historie van de apotheek betrouwbaar en redelijk volledig (77 procent) bleek te zijn.

Een probleem is wel dat deze vorm van preventie financieel niet wordt gehonoreerd.

Mede gezien de bevinding van Sprenger dat 95 procent van de oversterfte ten gevolge van influenza in de leeftijdgroep van 60 jaar en ouder plaatsvindt (14), zou te overwegen zijn de Nederlandse criteria voor het behoren tot een risicogroep uit te breiden met de Amerikaanse criteria. Dat wil zeggen: iedereen van 65 jaar en ouder, en van jongere patiënten iedereen met een risico. Het is daarbij wel van belang dat meer gegevens beschikbaar komen over de effectiviteit van griepvaccinatie. Veel artsen en patiënten zijn niet overtuigd van het nuttig effect van griepvaccinatie (2). Er zijn ons echter geen gerandomiseerde effectiviteitsstudies in voor de huisarts relevante populaties bekend.

De in dit artikel beschreven resultaten en overwegingen hebben geleid tot het opzetten van een randomised controlled trial naar de effectiviteit van influenzavaccinatie. Het onderzoek zal in 1991-92 door ons worden uitgevoerd onder patiënten van 60 jaar en ouder. 


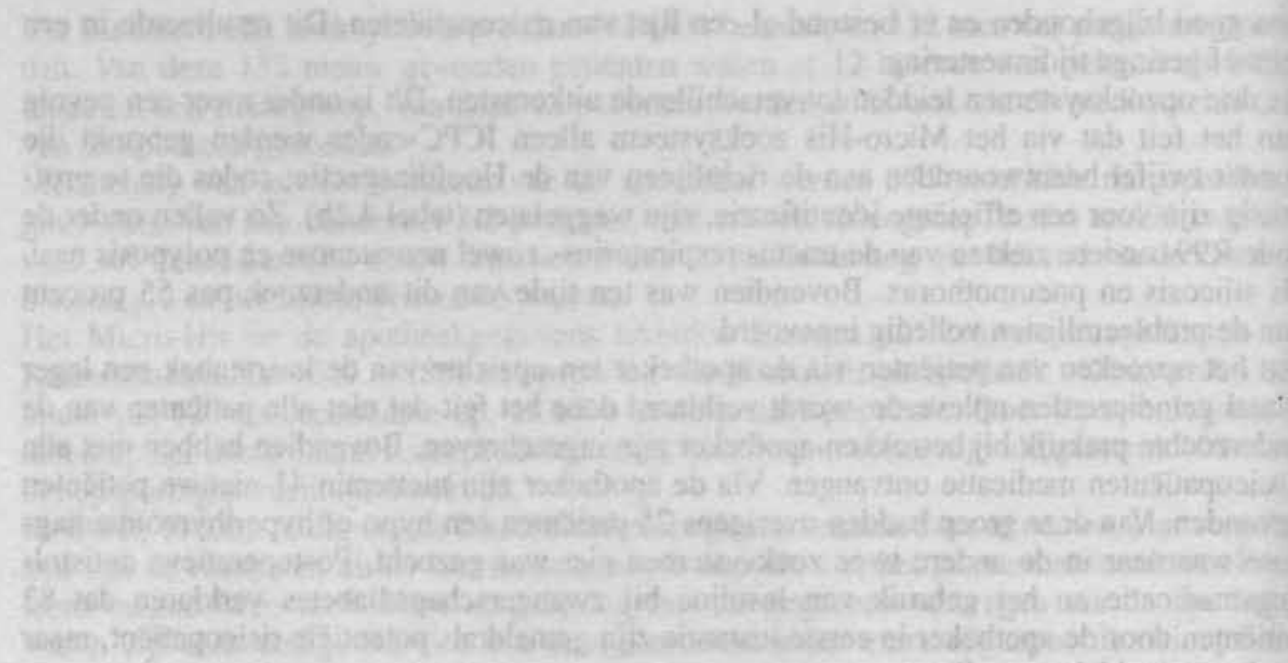

\section{LITERATUUR}

1 Geneeskundige Hoofdinspectie van de Volksgezondheid. Advies inzake vaccinatie tegen influenza. Rijswijk: GHI/INFZ, 1989

2 Nicholson KG, Wiselka MJ, May A. Influenza vaccination of the elderly: perceptions and policies of general practitioners and outcome of the 1985-86 immunization programme in Trent, UK. Vaccine 1987; 5: 302-06

3 Keitel WA, Cate TR, Couch RB. Efficacy of sequential annual vaccination with inactivated influenza virus vaccine. Am J Epidemiol 1988; 127: 353-64

4 Duthie jr EH, Rabinovitch RA, Rose HD. Tsitouras P, Gambert SR. Effectiveness of influenza vaccination in a long-term care setting. Wis Med J 1984; 83: 11-12

5 Veen WA van. Influenzavaccinatie: hoe effectief is het beleid? Huisarts Wet 1990; 33: 415-16

6 Alling DW. Blackwelder WC, Stuart-Harris $\mathrm{CH}$. A study of excess mortality during influenza epidemics in the United States, 1968-1976. Am J Epidemiol 1981; 113: 30-43

7 Barker WH, Mullooly JP. Impact of epidemic, type A influenza in a defined adult population. Am J Epidemiol 1980; 112: 798-811

8 Barker WH, Mullooly JP. Pneumonia and influenza deaths during epidemics. Implications for prevention. Arch Intem Med 1982; 142: 85-89

9 Barker WH, Mullooly JP. Influenza vaccination of elderly persons, reduction in pneumonia and influenza hospitalization and deaths. JAMA 1980; 244: 2547-49

10 Sprenger MJW, Beyer WRP, Ament AJHA, Rutten FFH, Masurel N. Influenzavaccinatie leidt tot kostenbesparing in de gezondheidszorg. Tijdschr Soc Gezondheidsz 1987; 65: 222-25

11 Hofstra ML, Braak EM ter, Werf G Th van der, Smith RJA. Een geautomatiseerd zoek- en oproepsysteem voor vaccinatie tegen influenza. Huisarts Wet 1990; 33: 429-32

12 Buchner DM, Larson EB, White RF. Influenza vaccination in community elderly. A controlled trial of postcards reminders. J Am Geriatr Soc 1987; 35: 755-60

13 McDowell I, Newll C, Rosser W. Comparison of three methods of recalling patients for influenza vaccination. Can Med Assoc J 1986; 135: 991-97

14 Sprenger MJW. The impact of influenza: an epidemiological study of morbidity, direct mortality and related mortality [Thesis]. Rotterdam: Erasmus Universiteit, 1990

15 Brimberry R. Vaccination high-risk patients for influenza. A comparison of telephone and mail reminder methods. J Fam Pract 1988; 26: 397-400

16 Frank JW, McMurray L, Henderson M. Influenza vaccination in the elderly: 2 . The economics of sending reminder letters. Can Med Assoc J 1985; 132: 516-18, 521

17 Mullooly JP. Increasing influenza vaccination among high-risk elderly: a randomized controlled trial of a mail cue in a HMO setting. Am J Public Health 1987; 77: 626-27 


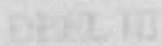

MIILTI-CEERETES ONDFRZCOEK

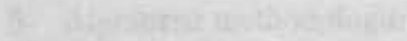

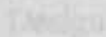

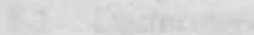

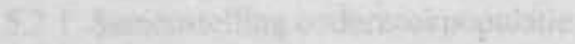

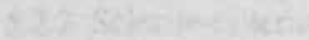

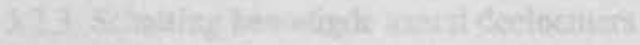

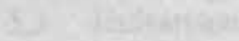

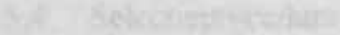

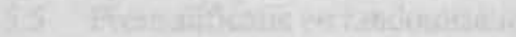

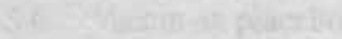

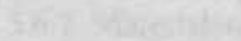

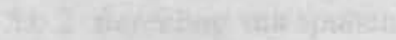

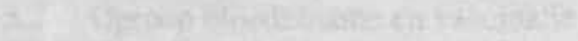

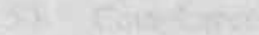

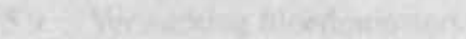

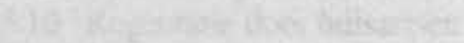

3)

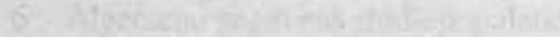

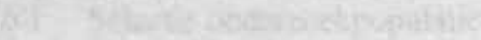

7.

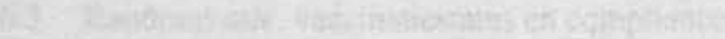

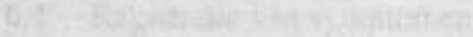

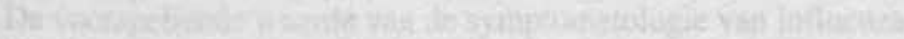

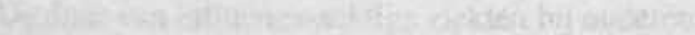

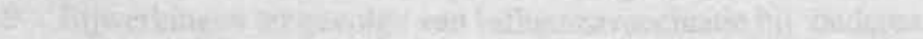

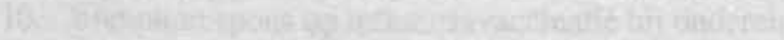

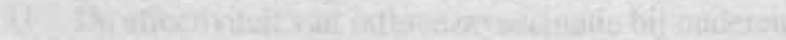


Mry:

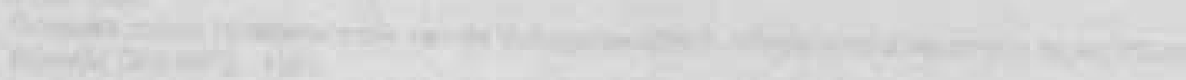

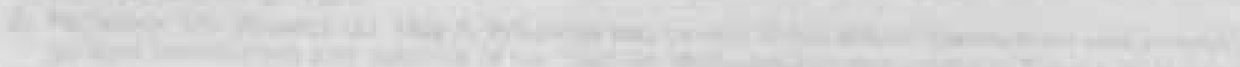

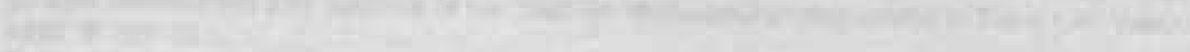

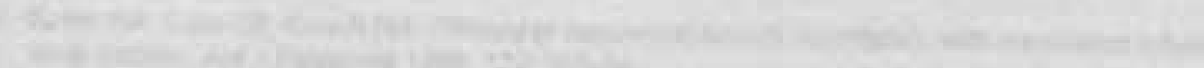

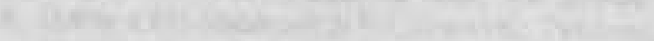

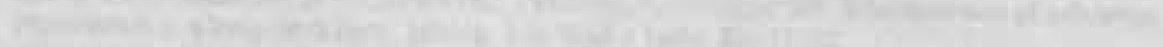

Then

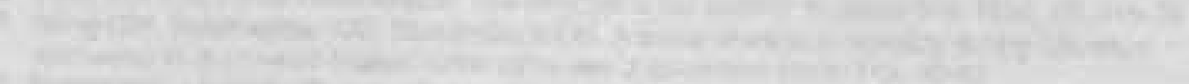

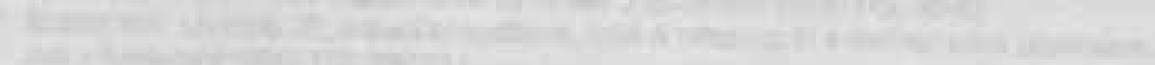

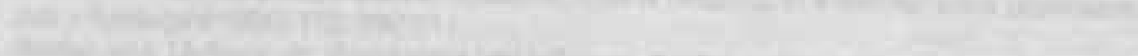

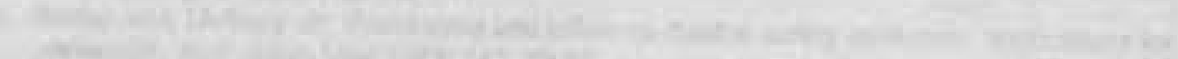

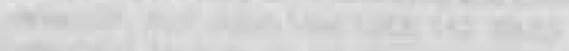

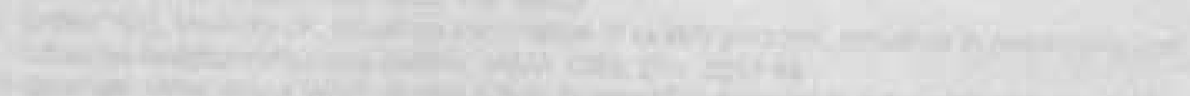

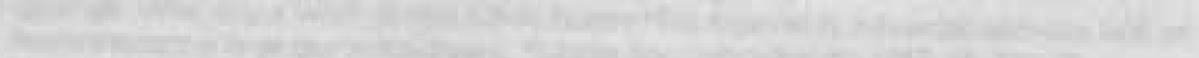

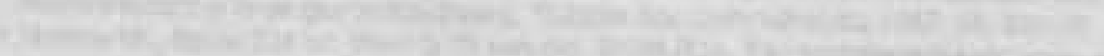

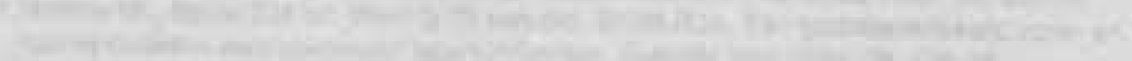

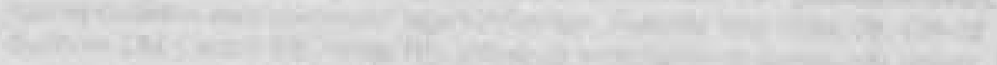

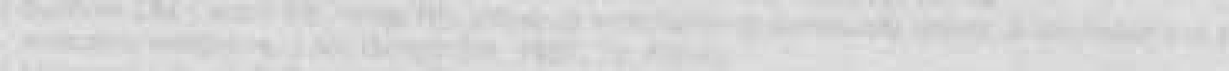

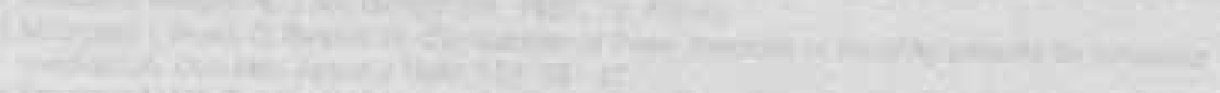

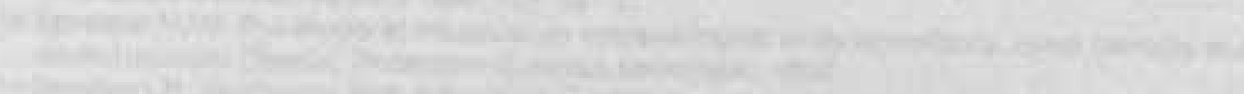

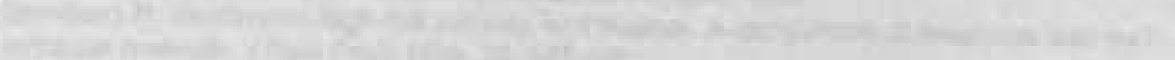

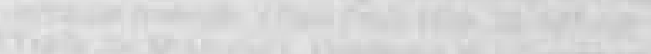

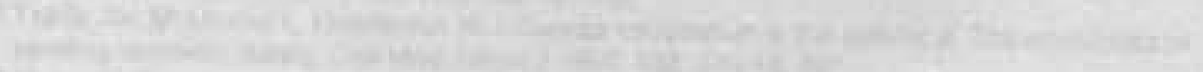

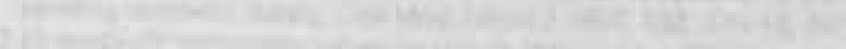

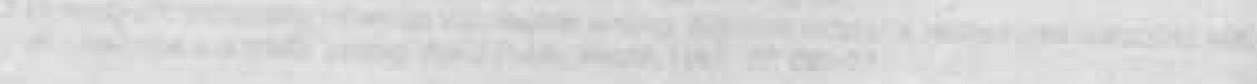




\section{MULTI-CENTER ONDERZOEK}

5 Algemene methodologie

5.1 Design

5.2 Deelnemers

5.2.1 Samenstelling onderzoekpopulatie

5.2.2 Selectie-criteria

5.2.3 Schatting benodigde aantal deelnemers

5.3 Huisartsen

5.4 Selectieprocedure

5.5 Prestratificatie en randomisatie

5.6 Vaccin en placebo

5.6.1 Materialen

5.6.2 Bereiding van spuiten

5.7 Oproep bloedafname en vaccinatie

5.8 Compliance

5.9 Verwerking bloedmonsters

5.10 Registratie door huisartsen

5.11 Enquête bij deelnemers

6 Algemene gegevens studiepopulatie

6.1 Selectie onderzoekpopulatie

6.2 Prestratificatie

6.3 Randomisatie, vaccinatiestatus en compliance

6.4 Registratie van symptomen

7 De voorspellende waarde van de symptomatologie van influenza

8 De duur van influenza-achtige ziekten bij ouderen

9 Bijwerkingen tengevolge van influenzavaccinatie bij ouderen

10 Immuunrespons op influenzavaccinatie bij ouderen

11 De effectiviteit van influenzavaccinatie bij ouderen 


\section{NG9}

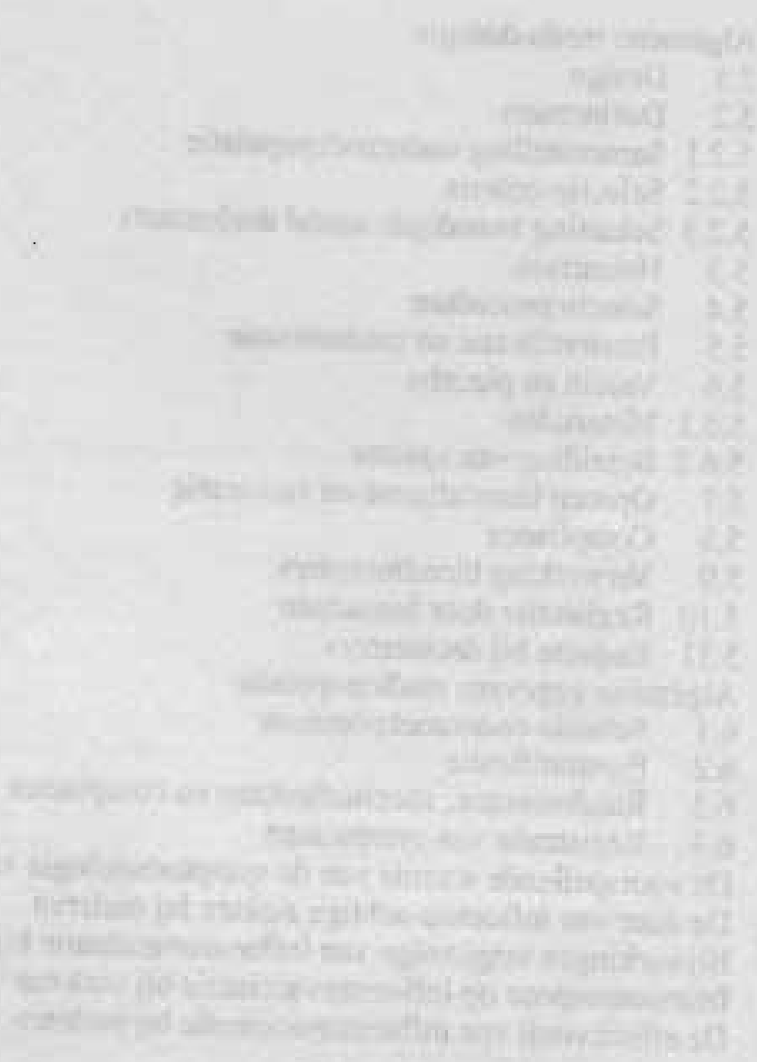

Whath

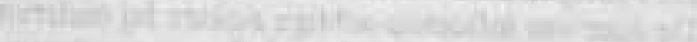

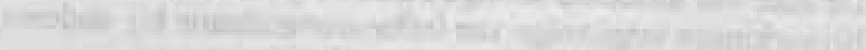

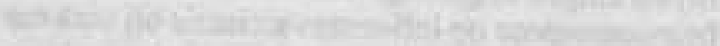

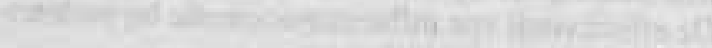




\section{HOOFDSTUK 5}

\section{ALGEMENE METHODOLOGIE}

\section{$5.1 \quad$ DESIGN}

Het effect van influenzavaccinatie werd bestudeerd door middel van een gerandomiseerde, dubbelblinde, placebo-gecontroleerde trial (RCT) in een doelgroep patiënten van 60 jaar en ouder, tevoren niet geregistreerd als behorende tot een risicogroep. De onderzoekperiode bedroeg vijf maanden (november 1991 tot april 1992). Van de patiënten uit de onderzoekpopulatie werd bij aanvang van de onderzoekperiode tweemaal een veneus bloedmonster afgenomen met tussenpauze van drie weken, waarbij direct na de eerste bloedafname de patiënten gevaccineerd werden met vaccin of placebo, volgens een randomisatieprotocol. Aan het einde van de onderzoekperiode werd bij alle deelnemers een laatste bloedmonster afgenomen. Een titerstijging van antilichamen in bloedmonster twee ten opzichte van monster een kan wijzen op een positieve immuunrespons op de vaccinatie. Een titerstijging in monster drie ten opzichte van twee kan wijzen op het doorgemaakt hebben van influenza. Door de serologische bevindingen te vergelijken met de door de huisarts gestelde klinische diagnose influenza en de diagnose influenza gesteld aan de hand van door patiënten ingevulde enquêtelijsten, werd het onderscheidend vermogen van het symptomencomplex

\section{Tabel 5.1.1 Schematische weergave van het onderzoekdesign.}

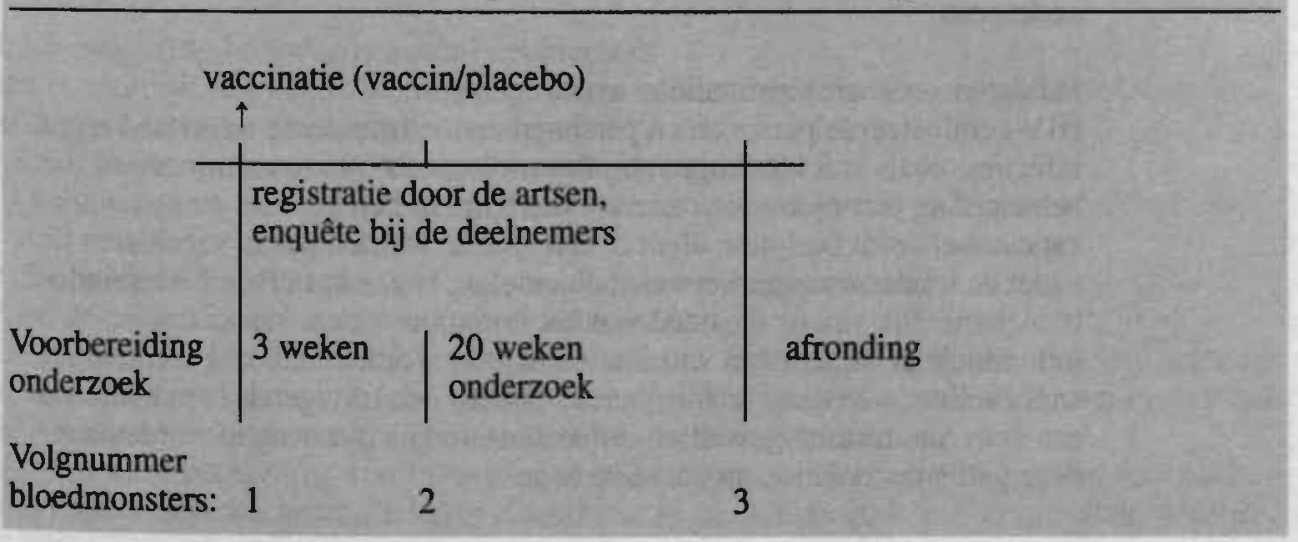


waarop de diagnose influenza gesteld wordt bestudeerd. In tabel 5.1.1 wordt een schematische overzicht van het onderzoekdesign weergegeven. De verschillende stappen in de opzet van dit onderzoek worden in de volgende paragrafen meer in detail besproken (bijlage 5.1.1).

\subsection{DEELNEMERS}

\subsubsection{Samenstelling onderzoekpopulatie}

Tot het onderzoek werden toegelaten patiënten van 60 jaar en ouder niet bekend als behorende tot een risicogroep. Voor de samenstelling van de risicogroepen is het advies van de Gezondheidsraad Commissie Vaccinatie tegen Influenza gevolgd (tabel 5.2.1.1) (1). In overleg met de Medisch Ethische Commissie van het Academisch Ziekenhuis Maastricht werd een uitnodigingsbrief opgesteld voor potentiële deelnemers aan het onderzoek. Daarin werd uitgelegd welke de doelstellingen van het onderzoek waren en wat de consequenties zouden zijn van deelname hieraan (bijlage 5.2.1).

Tabel 5.2.1.1 Advies Gezondheidsraad: commissie vaccinatie tegen influenza (1).

1. Patiënten voor wie jaarlijks vaccinatie sterk wordt aanbevolen:

1.1. Patiënten met afwijkingen en functiestoornissen van de luchtwegen en longen, zoals asthma bronchiale, chronische bronchitis, emfyseem, anthracosilicose, longfibrose, mucoviscoïdose, alsmede emstige vormen van kyphoscoliose, neurologische ademhalingsstoornissen, status na longresectie, status na laryngectomie en cheilognatho-palatoschisis.

1.2. Patiënten met afwijkingen die (kunnen) leiden tot insufficiëntia cordis, zoals doorgemaakt hartinfarct, angina pectoris, ritmestoormissen, klepgebreken en patiënten met chronische longstuwing.

1.3. Patiënten met diabetes mellitus.

1.4. Patiënten met chronische nierinsufficiëntie.

1.5. Patiënten met chronische stafylokokkeninfecties.

2. Patiënten voor wie gedurende perioden van enkele jaren vaccinatie wordt aanbevoelen: Patiënten die recent een beenmergtransplantatie hebben ondergaan.

3. Patiënten voor wie vaccinatie te overwegen is:

HIV-geïnfecteerde personen en personen met verminderde weerstand tegen infecties, zoals kan voorkomen bij hematologische nieuwvormingen, behandeling met cytostatica en radiotherapie. Indien bij deze patiënten tot vaccinatie wordt besloten, dient overwogen te worden pas te vaccineren nadat de immuunsuppresserende behandeling is gestopt of sterk verminderd is. Afhankelijk van de toestand van het immuunsysteem kan in het individuele geval met één vaccinatie volstaan worden, dan wel verdient het aanbeveling twee maal te vaccineren. Tijdens een (dreigende) epidemie van een voor amantadine gevoelige influenzastam kan overwogen worden aan deze patiënten ook nog amantadine te geven. 


\subsubsection{Selectie-criteria:}

Tot de trial werden toegelaten:

* patiënten van 60 jaar en ouder die naar eigen oordeel en dat van hun huisarts gezond waren;

* patiënten die een niet duidelijk verhoogd risico liepen bij het krijgen van influenza, naar het oordeel van de huisarts.

Uitgesloten werden:

* patiënten jonger dan 60 jaar;

* patiënten door huisarts aangemerkt als behorende tot een risicogroep (tabel 5.2.1.1);

* patiënten die in verzorgings-of verpleegtehuizen verbleven;

* patiënten die naar het oordeel van hun huisarts om medische redenen (multipele pathologie) niet geschikt waren voor deelname.

Motivatie inclusie- en exclusiecriteria:

Wij hebben in dit onderzoek gekozen voor een populatie van 60 jaar en ouder omdat:

* vijf en negentig procent van de oversterfte tengevolge van influenza plaatsvindt in de leeftijdsgroep van 60 jaar en ouder $(2,3)$;

* men aanneemt dat het immunologisch afweersysteem bij oudere mensen vermindert (4-6);

* in menige publicatie gesteld wordt dat een ieder van 60 jaar en ouder als risicopatient geduid moet worden $(2,3,7,8)$.

Indien een influenza-epidemie zich voordoet kan men verwachten dat in deze leeftijdsgroep zich de meeste morbiditeit en mortaliteit zal voordoen. Als influenzavaccinatie werkzaam is zal in deze leeftijdsgroep vaccinatie het meeste effect kunnen sorteren in de zin van het voorkómen van het optreden van influenza en het verminderen van het aantal complicaties ten gevolge van influenza (3).

Bij het beoordelen of een patiënt behoort tot een risicogroep wordt in Nederland anders geoordeeld dan bijvoorbeeld in landen als Amerika en Canada (8). Iemand met een ongecompliceerd doorgemaakt hartinfarct behoeft niet altijd opgenomen te worden in een risicogroep. Evenzo geldt dit voor patiënten met lichte vormen van asthma, bronchitis en emphyseem, en patiënten met bijvoorbeeld neurologische aandoeningen, zoals een cerebrovasculair accident. Daarnaast hanteren artsen hun eigen normen in deze. Dit gegeven bracht met zich mee dat achteraf alsnog patiënten werden gevonden die bij een ruimere definitie zouden kunnen behoren tot een risicogroep, maar gezien de lichtere vorm van de aandoening in kwestie en de interpretatie ervan hiertoe niet gerekend werden.

Patiënten die in een verzorgings- of verpleegtehuis verbleven werden uitgesloten omdat zij vaak aan multipele pathologie lijden. Bovendien verzorgt de medisch adviseur van deze inrichtingen meestal het vaccinatieprogramma voor alle bewoners.

Dat patiënten met ernstige pathologie, hoewel niet behorend tot een der risicogroepen, werden uitgesloten spreekt voor zich.

\subsubsection{Schatting benodigde aantal deelnemers}

Het is moeilijk een goede schatting te maken van het benodigde aantal patiënten voor deze RCT. Veel factoren zijn niet goed voorspelbaar:

* vindt het onderzoek plaats tijdens een influenza epidemie?

De incidentie van influenza is ongeveer twee procent wanneer zich geen epidemie voordoet $(9,10)$;

* zijn voldoende patiënten bereid aan het onderzoek deel te nemen?

* zal de compliance van de deelnemers voldoende zijn?

De berekening in tabel 5.2.3.1 toont welk relatief risico op het krijgen van influenza op voorhand kan worden verwacht, gegeven het deelnemersaantal aan de RCT, een Power van $80 \%$ en een $5 \%$ kans op een zogenaamde fout van de eerste soort $(\alpha)$.

Volgens deze berekening zou bij een populatie bestaande uit twee groepen van 650 patiënten, kunnen worden vastgesteld dat vaccinatie in tenminste $80 \%$ van de gevallen bescher- 
ming biedt tegen influenza indien de cumulatieve incidentie van influenza $2 \%$ bedraagt. Aangezien de uitval niet te voorspellen was werd besloten om een zo groot mogelijk aantal huisartsen te benaderen voor deelname aan het onderzoek. Beperkingen in deze betroffen logistieke en financiële grenzen.

Tabel 5.2.3.1 Gewenste populatiegrootte, gegeven de beschermingsgraad (B), het relatief risico op het krijgen van influenza bij niet gevaccineerden (RR) en de cumulatieve incidentie van influenza (i).

\begin{tabular}{rrrrr}
\hline B & $\mathrm{i}=0,018$ & $\mathrm{i}=0,02$ & $\mathrm{i}=0,024$ & $\mathrm{RR}$ \\
$90 \%$ & 500 & 450 & 400 & 0,10 \\
$80 \%$ & 700 & 650 & 550 & 0,20 \\
$70 \%$ & 950 & 850 & 700 & 0,30 \\
$60 \%$ & 1350 & 1200 & 1000 & 0,40 \\
$50 \%$ & 2250 & 2000 & 1700 & 0,50 \\
\hline
\end{tabular}

Gegevens verkregen van Dr C.T.M.C.N. Thijs, vakgroep Epidemiologie, Rijksuniversiteit Limburg.

\subsection{HUISARTSEN}

Een aantal huisartsen in de regio Zuid-en Midden-Limburg werd persoonlijk uitgenodigd aan het onderzoek deel te nemen. Het betrof twee groepen: huisartsen die meewerkten aan het Registratie Netwerk Huisartsen (RNH) (11) en huisartsen die niet aan het RNH meewerkten, maar die wel geïnteresseerd waren in het onderzoek. In totaal namen 34 huisartsen, verdeeld over 15 huisartspraktijken, deel aan het onderzoek (tabel 5.3.1).

Tabel 5.3.1 Overzicht van de deelnemende praktijken.

\begin{tabular}{rllll}
\hline $\begin{array}{c}\text { Volg- } \\
\text { nummer }\end{array}$ & Locatie & Soort praktijk & RNH & $\begin{array}{l}\text { Aantal deelnemende } \\
\text { huisartsen }\end{array}$ \\
\hline 1 & Stein & groep & ja & 4 \\
2 & Stein & solo & nee & 1 \\
3 & Stein & solo & nee & 1 \\
4 & Urmond & duo & nee & 2 \\
5 & Heerlen & groep & ja & 3 \\
6 & Maastricht & groep & ja & 3 \\
7 & Landgraaf & groep & ja & 3 \\
8 & Heerlen & solo & ja & 1 \\
9 & Haelen & solo & ja & 1 \\
10 & Elsloo & duo & nee & 2 \\
11 & Elsloo & duo & nee & 2 \\
12 & Beek & duo & nee & 2 \\
13 & Neerbeek & groep & ja & 4 \\
14 & Voerendaal & groep & ja & 3 \\
15 & Beek & duo & nee & 2 \\
\hline
\end{tabular}

Het totale patiëntenbestand van deze praktijken was 69.988 (gemiddeld 2.225 patiënten per huisarts). 
Alle patiënten uit de deelnemende praktijken, zijnde:

* patiënten jonger dan 60 jaar, of:

* bij de huisarts bekend als behorende tot een risicogroep (tabel 5.2.1.1), of:

* lijdend aan multipele pathologie, of:

* opgenomen in een verzorgings-verpleegtehuis

$$
\downarrow \text { nee } \downarrow \downarrow \text { ja } \rightarrow \text { exclusie }
$$

Uitnodiging aan overgebleven patiënten voor deelname aan het onderzoek.

* na uitnodigingsbrief informed consent verkregen? (bijlage 5.2.1 en 5.4.1)

$\downarrow$ ja $\downarrow \downarrow$ nee $\rightarrow$ exclusie

Vragenlijst aan overgebleven patiënten (bijlage 5.4.2 en 5.4.3)

* behoort patiënt alsnog tot een erkende risicogroep, of

* is er andere relevante pathologie aanwezig?

$$
\downarrow \text { nee } \downarrow \quad \downarrow \text { ja } \rightarrow \text { exclusie }
$$

Contrôle door deelnemende huisartsen van antwoorden op eerste vragenlijst

* definitieve toezegging van huisarts verkregen?

$\downarrow$ ja $\downarrow \downarrow$ nee $\rightarrow$ exclusie

Opname in onderzoekpopulatie

\section{TOELICHTING BIJ STROOMDIAGRAM}

Selectie patiënten uit de deelnemende praktijken

Daar niet alle deelnernende praktijken geautomatiseerd waren is aan de apothekers waarmee betreffende praktijken samenwerkiten, gevraagd om een overzicht samen te stellen van alle patiënten ouder dan 60 jaar. Aan de patiënten die voldeden aan de inclusiecriteria werd een vitnodiging gestuurd met Informed Consent (bijlage 5.2.1), opgesteld na overleg met de Medische Ethische Commissie van het Academisch Ziekenhuis te Maastricht. De patiënten werd gevraagd het bijgevoegde antwoordformulier (bijlage 5.4.1) in te vullen en per post te retourneren of in de praktijk van de eigen huisarts af te geven.

\section{Vragenlijsı aan patiënten}

Een vragenlijst (bijlage 5.4.2 en 5.4.3) met items ten aanzien van risico-aandoeningen en het wel of niet eerder gevaccineerd zijn, werd gebruikt omdat niet alle artsen dezelfde criteria hanteerden bij het bepalen welke patiënten tot een risicogroep behoren. Bovendien beschikten niet alle praktijken over een lijst van jaarlijks op te roepen patiënten voor een influenzavaccinatie en hadden sommige praktijken geen georganiseerd vaccinatieprogranıma. 


\section{Controle door deelnemende huisartsen}

$\mathrm{Na}$ verwerking van de gegevens verkregen uit de door de patiënt beantwoorde vragenlijs ontvingen de huisartsen een nieuwe lijst van potentiële deelnemers aan het onderzoek. De op deze lijst voorkomende patiënten waren door de onderzoeker voorzien van een diagnose, voor zover relevant en aanwezig. De artsen werden verzocht de lijst nogmaals kritisch te beoordelen, zowel op juistheid van de diagnose als op het eventueel niet terecht aanwezig zijn van patiënten op deze lijst.

\subsection{PRESTRATIFICATIE EN RANDOMISATIE}

Ter voorkoming van een scheve verdeling na randomisatie van het aantal patiënten in de te verwachten relatief kleine, klinisch relevante subgroepen, werd geprestratificeerd. Hierbij werden onder meer die deelnemers ingedeeld die opgegeven hadden een hart- of longaandoening of diabetes mellitus te hebben maar door hun huisarts niet gerekend werden tot de erkende risicogroepen omdat zij geen ernstige vormen van de betreffende aandoeningen vertoonden. De categorieën waren als volgt:

Stratum A: patiënten met angina pectoris, een coronair stenose of status na een hartinfarct

Stratum B: patiënten met andere hartaandoeningen, zoals atrium-fibrilleren, -flutter, Adam Stokes aanvallen, decompensatio cordis, of status na een myocarditis

Stratum C: patiënten met longaandoeningen zoals bronchitis, CARA, asthma, silicose, emphyseem, status na een pneumothorax of pleuritis, vroegere tuberculosis

Stratum D: patiënten met diabetes mellitus

Stratum E: alle gezonde patiënten en patiënten met status na een cerebro vasculair accident, transiant ischaemic attack, kyphoscoliosis, perifeer arterieel vaatlijden en sommige neurologische en schildklieraandoeningen.

Het was te verwachten dat niet alle patiënten, die hadden toegezegd te zullen deelnemen aan het onderzoek, inderdaad gevolg zouden geven aan de oproep voor vaccinatie. Om te voorkomen dat door te veel uitvallers de randomisatie zou mislukken werden de spuiten in random volgorde toegediend tijdens de vaccinatie spreekuren. Ter voorbereiding hiervan werden de spuiten (vaccin of placebo) twee weken voor de startdatum van bloedafname en vaccinatie gerandomiseerd per stratum en vervolgens voorzien van een uniek volgnummer. In de data-analyse werden de strata A en B onder één noemer gebracht.

\section{6}

\section{VACCIN EN PLACEBO}

\subsubsection{Materialen}

Als vaccin werd gekozen voor het "Griepvaccin PCH" (Fluvirin") geleverd door Pharmachemie B.V. Holland, charge nummer E 1194 DA. Fabrikant hiervan was Evans Medical Ltd, Langhurst, Horsham, Engeland. Dit vaccin was evenals de andere in Nederland verkrijgbare griepvaccins samengesteld volgens de richtlijnen van de World Health Organisation en de Nederlandse Gezondheidsautoriteiten. Elke 0,5 milliliter dosering bevatte: A/Singapore/6/86 (H1N1) equivalent met 15 microgram HA, A/Beijing/353/89 (H3N2) equivalent met 15 microgram $\mathrm{HA}, \mathrm{B} /$ Panama/45/90 equivalent met 15 microgram $\mathrm{HA}$ en $\mathrm{B} / \mathrm{Beijing} / 1 / 87$ equivalent met 15 microgram $\mathrm{HA}$, met als conserveermiddel thiomersal 0,1 $\mathrm{mg} / \mathrm{ml}$. Als placebo werd $0,5 \mathrm{ml}$ fysiologisch zout gebruikt. Aangezien geen aan de gang. bare influenza spuiten identieke lege spuiten verkrijgbaar waren, werden vaccin en placebo overgebracht in BD Plastipack 1 milliliter spuiten. Dit werd verzorgd door de apothekers in Stein, (drs H.J.L.M. Pieters en drs P.M.J. Stassen), evenals het etiketteren van vaccin en placebo volgens de randomisatielijst en het bijhouden van de dagelijkse overzichten van toegediende spuiten per stratum en praktijk. 


\subsubsection{Bereiding van de spuiten}

De jaarlijks gecontroleerde laminair flow kast (klasse 100) werd 15 minuten voor aanvang van de werkzaamheden aangezet. Vervolgens werden de binnenwanden afgenomen met $1 \%$ Hibitane in ethanol $70 \%$. De bereider en helper wasten gedurende 3 minuten handen en onderarmen grondig met Hibiscrub. Daarna werden handen en onderarmen afgespoeld met kraanwater, en overgoten met $70 \%$ ethanol. Na droging aan de lucht in de laminair flow kast kon met de werkzaamheden aangevangen worden. Mondmasker en nurse-cap werden gedurende de hele duur van de werkzaamheden gedragen.

Vaccins werden als volgt klaargemaakt:

De inhoud van een spuit PCH vaccin $(=0,5 \mathrm{ml})$ werd overgebracht in een BD Plastipack spuit van $1 \mathrm{ml}$ via de normale opening. Eventuele luchtbellen werden door middel van zacht tikken verwijderd. Vervolgens werd de steriele naald $(0,6 \times 25 \mathrm{~mm})$ samen met de kap (vooraf niet verwijderd) op de spuit geplaatst. De aldus gevulde spuit werd doorgegeven aan de helper buiten de kast die de spuit etiketteerde volgens de randomisatielijst.

Placebo's werden als volgt klaargemaakt:

In een flacon van $50 \mathrm{ml} 0.9 \% \mathrm{NaCL}$ werden 2 naalden geprikt (één ter ontluchting). In een, aan het vaccin identieke BD Plastipack spuit van $1 \mathrm{ml}$ werd een overeenkomstige hoeveelheid $(0,5 \mathrm{ml})$ fysiologische zoutoplossing gezogen. Eventuele luchtbellen werden door zacht tikken verwijderd. Vervolgens werd de steriele naald $(0,6 \times 25 \mathrm{~mm})$ samen met de kap (vooraf niet verwijderd) op de spuit geplaatst. De aldus gevulde spuit werd doorgegeven aan de helper buiten de kast die de spuit etiketteerde, ook volgens de randomisatielijst.

Het etiket bevatte de volgende gegevens:

Stratum $(A, B, C, D$ of $E)$, volgnummer volgens randomisatie, datum van toediening, nummer entteam. Voorbeeld:

NUMMER: B 623 DATUM : 01.11.91 TEAM : 2

De geëtiketteerde spuiten werden op volgorde volgens randomisatielijst per stratum ( $A, B, C, D$ of $E$ ) en entteam (twee) gestoken in een polystyreen blok van geschikte afmeting en geplaatst in een kunststof container. Vers aangemaakte, evenals teruggebrachte spuiten werden meteen opgeslagen in een gekoelde kelder bij een temperatuur tussen de 11 en $14^{\circ} \mathrm{C}$.

\subsection{OPROEP, BLOEDAFNAME EN VACCINATIE}

De deelnemers aan het onderzoek ontvingen een oproepbrief met een ingevulde afspraakkaart (bijlage 5.7.1) voor de vaccinatie en de eerste twee bloedafnames. Voor de derde bloedafname, 5 maanden later, werd een aparte oproep verstuurd (bijlage 5.7.2). Per 10 minuten werden 4 patiënten afgesproken. De eerste ronde vond plaats van 1 november tot en met 15 november 1991. Hierbij werd van alle deelnemers een veneus bloedmonster ( 9 milliliter) verzameld voorafgaande aan de injectie in de bovenarm met vaccin of placebo. De tweede ronde liep van 22 november tot en met 6 december 1991, de derde van 6 april tot en met 16 april 1992. (bijlage 5.7.3 en 5.7.4). Er werd gewerkt met twee ploegen, elk bestaande uit een arts voor de vaccinatie (alleen in de eerste ronde), een assistente voor bloedafname en een assistente voor het administratieve werk. De vaccinatie geschiedde met naalden voor intramusculaire injectie, maat $0,6 \times 25 \mathrm{~mm}$. Het veneuze bloedmonster werd middels een vacutainer bloedafnamesysteem steriel opgevangen in $9,2 \mathrm{ml}$ grote STT bloedafnamebuis met gel en clotactivator voor serumscheiding, afmeting $16 \times 100 \mathrm{ml}$. Vaccinatie en bloedafnames vonden plaats in de praktijk van de eigen huisarts.

Bij binnenkomst overhandigde de deelnemer zijn afspraakkaart waarop zijn naam en een tevoren toegekend uniek deelnemersnummer vermeld stond. Aan de hand van een deelnemerslijst werd naam en nummer gecontroleerd. $\mathrm{Na}$ de afname van het eerste bloedmonster werd in de deelnemerslijst opgezocht tot welk stratum de deelnemer behoorde en werd de 
aan de beurt zijnde genummerde spuit door de arts toegediend in de bovenarm van de patiënt. Het. nummer van de spuit werd achter de naam van de deelnemer genoteerd.

\subsection{COMPLIANCE}

Ter bevordering van de compliance werden de volgende maatregelen genomen:

* Op de uitnodigingen werd het briefhoofd van de huisarts vermeld; de huisarts ondertekende de uitnodiging persoonlijk. Tevens geschiedden de bloedafnames in de praktijk van de eigen huisarts.

* Het privé telefoonnummer van de onderzoeker en het telefoonnummer van de researchassistente werden aan de deelnemende patiënten beschikbaar gesteld. Van het privé-telefoonnummer werd ook 's avonds en tijdens de weekenden regelmatig gebruik gemaakt.

* Tijdens de bloedafnamesessies werden deelnemers die twintig minuten na de voor hen gemaakte afspraak nog niet waren verschenen, opgebeld met het verzoek om alsnog te komen. Meestal waren deze patiënten de afspraak vergeten.

* Iedere avond werd aan de hand van de afspraaklijsten nogmaals gecontroleerd of alle deelnemers waren verschenen. Indien dit niet het geval was werd de volgende ochtend opgebeld en alsnog een nieuwe afspraak gemaakt. Omdat in de meeste praktijken op twee achtereenvolgende dagen een sessie plaatsvond en omdat verschillende praktijken in elkaars nabijheid gelocaliseerd waren, leverde dit geen onoverkomelijke logistieke problemen op.

* Patiënten die om een bepaalde reden de praktijk niet konden bezoeken (immobiel, bedlegerig, pas geopereerd) werden thuis bezocht.

* Er bestond een financiële tegemoetkoming zowel voor deelnemers als voor de huisartsen.

\subsection{VERWERKING BLOEDMONSTERS}

De per dag verzamelde bloedmonsters werden 's nachts bewaard in een koelkast bij $4^{\circ} \mathrm{C}$ elsius, waarna ze de volgende ochtend in het bacteriologisch laboratorium van het Maaslandziekenhuis te Sittard verwerkt werden en vervolgens ingevroren bij $-20^{\circ} \mathrm{Celsius}$. Bij de verwerking van de bloedmonsters werd het volgende protocol gehanteerd:

* vacutainers met rubberdop centrifugeren gedurende 10 minuten bij $1800 \mathrm{xg}$ omwentelingen;

* van vacutainers en serumbuisjes doppen steriel verwijderen;

* serum steriel (door te flamberen) overpipetteren;

* serumbuisje voorzien van juiste etiket;

* serumbuisje invriezen bij $-20^{\circ} \mathrm{Celsius;}$

Na de tweede prikronde en de laatste prikronde werden de verzamelde bloedrnonsters in grote koeldozen per auto vervoerd naar het Nationale Influenza Centrum te Rotterdam alwaar, na afloop van de onderzoekperiode, de serologische analyse plaatsvond (zie hoofdstukken 9,10 en 11).

\subsection{REGISTRATIE DOOR HUISARTSEN}

Gedurende de onderzoekperiode, van de eerste tot en met de laatste ronde van bloedafnames, registreerden de deelnemende huisartsen bij patiënten die zich meldden met verschijnselen van griep de relevante symptomen op een voorgedrukte lijst (bijlage 5.10.1). Tijdens dit contact en drie weken later werd, zo mogelijk, een bloedmonster afgenomen om een tussentijdse titerstijging van antilichamen tegen influenza te kunnen objectiveren. 
Voor het stellen van de diagnose influenza of influenza-achtige ziekte gebruikten we de criteria volgens de International Classification of Health Problems in Primary Care (ICHPPC-2-defined), respectievelijk de peilstations (tabel 5.10.1) (12,13). Van de ICHPPC2-defined zijn afgeleid de criteria van de International Classification of Primary Care (ICPC) $(14,15)$.

\section{Tabel 5.10.1 Criteria voor het stellen van de diagnose influenza of influenza-achtige ziekte.}

Volgens de

PEILSTATIONS (13): 1 Een acuut begin, dus hoogstens een prodromaal stadium van drie tot vier dagen (inclusief preëxistente luchtweginfectie op een niet ziekmakend niveau) en.

2 de infectie moet gepaard gaan met een temperatuursverhoging van tenminste $38^{\circ} \mathrm{C}$, rectaal en

3 tenminste één van de volgende symptomen moet aanwezig zijn: hoest, coryza, rauwe keel, frontale hoofdpijn, retrosternale pijn, myalgieën.

Volgens de

ICHPPC-2-defined (12): Plotseling begin, hoesten, koude rillingen, koorts, algehele malaise, hoofdpijn, myalgieën, rode keel of rhinitis, contact met influenza. Voor het stellen van de diagnose moet voldaan zijn aan tenminste én van de drie volgende criteria:

a viruskweek of serologische bevestiging,

b een influenza epidemie en vier van boven aangehaalde symptomen,

c zes van boven aangehaalde symptomen.

\subsection{ENQUETE BIJ DEELNEMERS}

De deelnemers ontvingen aan het eind van de eerste observatieperiode (1 novernber 1991 1 januari 1992) een vragenlijst (bijlage 5.11.1 en 5.11.2) met het verzoek deze lijst in te vullen. Deze lijst bevatte vragen over het eventueel doorgemaakt hebben van een griepepisode en de symptomen die zich hierbij voordeden, alsmede een aantal vragen over eventuele bijwerkingen van de "vaccinatie". Aan het begin van de tweede periode (1 januari 1992 -15 april 1992) ontvingen de patiënten een vergelijkbare vragenlijst (bijlage 5.11.3). Daarin waren de vragen over bijwerkingen weggelaten. De deelnemers werden verzocht deze formulieren aan het einde van beide observatieperioden in te leveren.

\section{Toelichting}

- Door de door de huisarts gestelde diagnose influenza of influenza-achtige ziekte en de diagnose influenza of influenza-achtige ziekte gesteld aan de hand van de enquêteformulieren te vergelijken met de serologische bevindingen, kon een inzicht verkregen worden in het onderscheidend vermogen van het symptomencomplex waarop de diagnose influenza gesteld wordt.

- Om het geheugen niet te zeer op de proef te stellen hebben de deelnemers tweemaal een enquêteformulier ontvangen. Indien tijdens de tweede periode een formulier werd geretourneerd, werd een nieuw formulier voor de resterende periode verstuurd. Een dagboekmethode (in plaats van enquête) leek ons minder betrouwbaar, omdat in dat geval de aandacht bij de patiënt zou leiden tot een vertekening van de resultaten. 


\section{LITERATUUR}

1 Gezondheidsraad: Commissie vaccinatie tegen influenza. Vaccinatie tegen influenza; seizoen 1991-1992. Den Haag: Gezondheidsraad, 1991/15

2 Sprenger MJW. The impact of influenza: an epidemiological study of morbidity, direct mortality and related mortality [Thesis]. Rotterdam: Erasmus Universiteit Rotterdam, 1990

3 Barker WH, Mullooly JP. Impact of epidemic type A influenza in a defined adult population. Am J Epidemiol 1980; 112: 798-811

4 Strassburg MA, Greenland S, Sorvillo FJ, Lieb LE, Habel LA. Influenza in the elderly: report of an outbreak and a review of vaccine effectiveness reports. Vaccine 1986; 4: 38-44

5 Gardner ID. The effect of aging on susceptibility to infection. Rev Infect Dis 1980; $25: 801-10$

6 Keren G, Segev S, Morag A, Zakay-Rones Z, Barzilai A. Rubinstein A. Failure of influenza vaccination in the aged. J Med Virol 1988; $25: 85-89$

7 Veen WiÂ van. Influenzavaccinatie: hoe effectief is het beleid? Huisarts Wet 1990; 33: 415-16

8 Govaert ThIME, Dinant GJ, Knottnerus JA. Vaccinatie tegen influenza in een huisartspraktijk. Opkomst en vaccinatiegraad van risicopatiënten. Huisarts Wet 1991; 34: 478-81

9 Sprenger MJW, Diepersloot RJA, Stuiver M, Postema CA, Masurel N. Influenza 1989/90: A-H3N2-Virus verwant aan hel vaccinvirus. Ned Tijdschr Geneeskd 1990; 134: 663-34

10 Fleming DM, Crombie DL. The incidence of common infectious diseases: the weekly returns service of the Royal College of General Practitioners. Health Trends 1985; 17: 13-16

11 Hoppener P, Knottnerus JA, Metsemakers JFM, Kocken RJJ, Limonard ChBG. Het Registratienet Huisartspraktijken van de Rijksuniversiteit Limburg. Een geautomatiseerd steekproefbestand voor huisartsgeneeskundig onderzoek. Huisarts Wet 1990; 33: 66-69

12 Classification Committee of WONCA. ICHPPC-2-defined. Inclusion criteria for the use of the rubric: of the International Classification of Health Problems in Primary Care. Oxford: Oxford University Press, 1983

$13 \mathrm{Pel}$ JZS. Proefonderzoek naar de frequentie en de etiologie van griepachtige ziekten in de winter 1963-1964. Huisarts Wet 1965; 8: 321-24

14 Lamberts $\mathrm{H}$, Wood M. International Classification of Primary Care. Oxford: Oxford University Press 1983

15 Registratienet Huisartspraktijken Fijksuniversiteit Limburg (RNH). Het gebruik van de ICPC lijst (International Classification of Primary Care). Maastricht: Rijksuniversiteit Limburg, 1988 
HOOFDSTUK 6

\section{ALGEMENE GEGEVENS STUDIEPOPULATIE}




\subsection{SELECTIE ONDERZOEKPOPULATIE}

Totale praktijkpopulatie

68.988

Basispopulatie ( 60 jaar en ouder)

11.762

Over na toepassing exclusiecriteria

9.907

$\downarrow$

Respons op uitnodigingsbrief (bijlage 5.2.1, hoofdstuk 5)

4.532

$\downarrow$

Accoord met informed consent ( $27 \%$ van de uitnodigingen)

2.063

$\downarrow$

Aantal patiënten dat vragenlijst (bijlage 5.4.3, hoofdstuk 5) retourneerde

1.952

$\downarrow$

Uitgenodigd voor deelname aan onderzoek, na contrôle door huisartsen

$\downarrow$

Onderzoekpopulatie deelnemers eerste ronde: 51 patiënten vielen alsnog uit wegens zich bedenken, ziekte, vakantie of leeftijd (te jong)

$\downarrow$

Deelname aan tweede ronde bloedafname

1.824

$\downarrow$

Deelname aan laatste ronde bloedafname

(uitval van 1,2\% ten opzichte van de onderzoekpopulatie)

Tabel 6.1.1 Leeftijd-en geslachtsverdeling van de onderzoekpopulatie.

\begin{tabular}{lrrrrrrr}
\hline leeftijd & \multicolumn{2}{c}{ man } & \multicolumn{2}{c}{ vrouw } & \multicolumn{2}{c}{ totaal } \\
\hline & $(\mathrm{n})$ & $(\%)$ & $(\mathrm{n})$ & $(\%)$ & & $(\mathrm{n})$ & $(\%)$ \\
\hline $60-64$ & 377 & 43,4 & 387 & 39,9 & 764 & 41,6 \\
$65-69$ & 257 & 29,6 & 273 & 28,2 & 530 & 28,8 \\
$70-74$ & 150 & 17,3 & 203 & 20,9 & 353 & 19,2 \\
$75-79$ & 53 & 6,1 & 74 & 7,7 & 127 & 6,9 \\
$80-84$ & 24 & 2,7 & 24 & 2,5 & 48 & 2,6 \\
$>85$ & 8 & 0,9 & 8 & 0,8 & 16 & 0,9 \\
\hline Totaal & 869 & 100 & 969 & 100 & 1838 & 100
\end{tabular}


Tabel 6.1.2 Vaccinatiestatus mannen en vrouwen.

\begin{tabular}{|c|c|c|c|c|c|c|}
\hline & \multicolumn{2}{|c|}{ Vaccin } & \multicolumn{2}{|c|}{ Placebo } & \multicolumn{2}{|c|}{ Totaal } \\
\hline & (n) & $(\%)$ & (n) & $(\%)$ & (n) & $(\%)$ \\
\hline $\begin{array}{l}\text { Man } \\
\text { Vrouw }\end{array}$ & $\begin{array}{l}420 \\
507\end{array}$ & $\begin{array}{l}45,3 \\
54,7\end{array}$ & $\begin{array}{l}449 \\
462\end{array}$ & $\begin{array}{l}49,3 \\
50,7\end{array}$ & $\begin{array}{l}869 \\
969\end{array}$ & $\begin{array}{l}47,3 \\
52,7\end{array}$ \\
\hline Totaal & 927 & 100 & 911 & 100 & 1838 & 100 \\
\hline
\end{tabular}

De gemiddelde leeftijd van de onderzoekpopulatie was 67 jaar (standaard deviatie 6; mediaan 66) met een range van 60 tot 91 jaar (tabel 6.1.1). Het aantal met vaccin respectievelijk placebo gevaccineerde mannen $(n=869)$ en vrouwen $(n=969)$ wordt weergegeven in tabel 6.1.2.

\subsection{PRESTRATIFICATIE}

Aan de hand van de gegevens verstrekt door patiënten en huisartsen bleken in de onderzoekpopulatie 249 patiënten een hartaandoening te hebben, 244 een longaandoening (44 hiervan hadden ook een hartaandoening) en 59 patiënten hadden diabetes mellitus, waarvan 18 ook een hart- en/of longaandoening. Deze aandoeningen waren naar het oordeel van de eigen huisarts niet van dien aard dat vaccinatie noodzakelijk was. De deelnemende huisartsen leken het begrip "risicopatiënt" verschillend te interpreteren. Ook was het vaccinatiebeleid van de artsen niet identiek. Sommigen riepen hun patiënten op, anderen lieten het initiatief over aan de patiënt. Indeling in strata werd verricht aan de hand van de resultaten van de door de patiënt ingevulde vragenlijst (bijlage 5.4.3, hoofdstuk 5) en de door de huisarts gecontroleerde diagnose. Uit tabel 6.2 .1 blijkt dat het risicostratum zoals opgegeven door de deelnemers in $92,3 \%(1696 / 1838)$ der gevallen overeenkwam met dat van de huisarts. De informatie gegeven door de deelnemers via de vragenlijst was dus in hoge mate betrouwbaar.

Tabel 6.2.1 Resultaten van prestratificatie .

\begin{tabular}{lrrrrr}
\hline $\begin{array}{l}\text { Na informatie } \\
\text { van patiënt }\end{array}$ & \multicolumn{7}{c}{$\begin{array}{c}\text { Na controle } \\
\text { door de huisarts }\end{array}$} & Totaal \\
\hline Stratum * & 1 & 2 & 3 & 4 & $\mathrm{n}$ \\
\hline 1 & $\mathrm{n}$ & $\mathrm{n}$ & $\mathrm{n}$ & $\mathrm{n}$ & 278 \\
& 202 & 15 & 4 & 57 & 186 \\
3 & 8 & 172 & 0 & 6 & 37 \\
4 & 0 & 0 & 37 & 0 & 1337 \\
\hline Totaal & 39 & 13 & 0 & 1285 & 1838 \\
* stratum 1: patiënten met hartaandoeningen \\
stratum 2: patiënten met longaandoeningen \\
stratum 3: patiënten met diabetes mellitus \\
stratum 4: overige deelnemers \\
$\begin{array}{l}\text { De deelnemers behorende tot stratum 1,2 en 3 werden } \\
\text { door de huisarts niet als risicopatiënt beschouwd. }\end{array}$
\end{tabular}




\subsection{RANDOMISATIE, VACCINATIESTATUS EN COMPLIANCE}

Van de onderzochte populatie ontvingen 927 patiënten vaccin en 911 placebo. Het aantal met vaccin respectievelijk placebo gevaccineerde deelnemers per stratum wordt weergegeven in tabel 6.3.1. Mede dankzij de prestratificatie, was de randomisatie geslaagd, getuige de tabellen 6.1.2 en 6.3.1.

Er waren $185(10,1 \%)$ deelnemers die ook tijdens de twee voorafgaande seizoenen gevaccineerd zijn geweest (tabel 6.3.2).

Tweeëntwintig van de 1838 gerandomiseerde deelnemers beëindigden hun deelname voortijdig; 13 gevaccineerden en 9 niet gevaccineerden (tabel 6.3.3).

De redenen van uitval waren: * gestorven (niet ten gevolge van influenza)

* intercurrente ziekte (cerebro vasculair accident) 3

* geen interesse meer

* vakantie

* huisarts had reeds vaccin toegediend

Tabel 6.3.1 Vaccinatiestatus van de deelnemers per stratum.

\begin{tabular}{lrcrc}
\hline Stratum * & \multicolumn{2}{c}{ Vaccin $(\mathrm{n}=927)$} & \multicolumn{2}{c}{ Placebo $(\mathrm{n}=911)$} \\
& $\mathrm{n}$ & \multicolumn{1}{c}{$\%$} & $\mathrm{n}$ & $\%$ \\
\hline Hartaandoening & 125 & 13,5 & 124 & 13,6 \\
Longaandoening & 105 & 11,3 & 95 & 10,4 \\
Diabetes Mellitus & 21 & 2,3 & 20 & 2,2 \\
Overige dee!nemers & 676 & 72,9 & 672 & 73,8 \\
\hline Totaal & 927 & 100 & 911 & 100 \\
* Tevoren niet door huisarts als risicopatiënt beschouwd. &
\end{tabular}

Tabel 6.3.2 Aantal deelnemers dat in 1989 en 1990 gevaccineerd werd; van 2 deelnemers waren de gegevens niet volledig.

\begin{tabular}{|c|c|c|c|}
\hline \multirow[b]{2}{*}{ Vacc.' 90} & \multicolumn{2}{|c|}{ Vacc.' 89} & \multirow[b]{2}{*}{ Totaal } \\
\hline & $\mathrm{ja}$ & nee & \\
\hline $\begin{array}{l}\text { ja } \\
\text { nee }\end{array}$ & $\begin{array}{r}185 \\
21\end{array}$ & $\begin{array}{r}32 \\
1598\end{array}$ & $\begin{array}{r}217 \\
1619\end{array}$ \\
\hline Totaal & 206 & 1630 & 1836 \\
\hline
\end{tabular}


Tabel 6.3.3 Reden van uitval tijdens de onderzoekperiode.

\begin{tabular}{|c|c|c|c|c|}
\hline patiëntnummer & oorzaak & $\begin{array}{l}\text { deelname } \\
\text { aan ronde }\end{array}$ & vaccin & placebo \\
\hline $1-710$ & cerebrovasculair accident & 1 en 2 & & $\mathrm{x}$ \\
\hline $2-38$ & vakantie & 1 en 2 & & $\mathrm{x}$ \\
\hline $3-141$ & overleden; hartinfarct & 1 en 2 & & $\mathrm{x}$ \\
\hline $4-64$ & overleden; hartinfarct & 1 en 2 & $\mathrm{x}$ & \\
\hline $4-99$ & overleden;hartinfarct & 1 en 2 & $\mathrm{x}$ & \\
\hline $5-18$ & geen interesse meer & 1 & & $\mathrm{x}$ \\
\hline $5-421$ & overleden; hartfalen & 1 en 2 & $\mathrm{x}$ & \\
\hline $6-112$ & overleden; hartinfarct & 1 & & $\mathrm{x}$ \\
\hline $6-687$ & overleden;hartinfarct & 1 & $\mathrm{x}$ & \\
\hline $6-752$ & geen interesse meer & 1 & $\mathrm{x}$ & \\
\hline $6-818$ & cerebrovasculair accident & 1 en 2 & & $\mathrm{x}$ \\
\hline $7-307$ & overleden;hartinfarct & 1 en 2 & $\mathrm{x}$ & \\
\hline $9-432$ & geen interesse meer & 1 & $\mathrm{x}$ & \\
\hline $11-210$ & cerebrovasculair accident & 1 & $\mathrm{x}$ & \\
\hline $13-94$ & overleden;aneurysma aortae & 1 en 2 & $\mathrm{x}$ & \\
\hline $13-249$ & geen interesse meer & 1 & $\mathrm{x}$ & \\
\hline $14-619^{*}$ & overleden; hartinfarct & 1 en 2 & & $\mathrm{x}$ \\
\hline $15-187$ & door huisarts vaccin toegediend & 1 en 2 & $\mathrm{x}$ & \\
\hline $15-354$ & geen interesse meer & 1 & $\mathrm{x}$ & \\
\hline $15-355$ & geen interesse meer & 1 & $\mathrm{x}$ & \\
\hline $15-394$ & geen interesse meer & 1 en 2 & 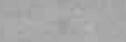 & $\mathrm{x}$ \\
\hline $15-842$ & geen interesse meer & 1 en 2 & & $\mathrm{x}$ \\
\hline \multicolumn{3}{|c|}{ Totaal } & 13 & 9 \\
\hline
\end{tabular}

\subsection{REGISTRATIE VAN SYMPTOMEN}

De deelnemende huisartsen registreerden gedurende de onderzoekperiode bij 48 patiënten een episode van influenza. Bij 32 van deze 48 patiënten werd bij het eerste contact en drie weken later een extra bloedmonster afgenomen om een tussentijdse titerstijging (bewijzend voor influenza) te objectiveren. Voornamelijk wegens organisatorische problemen konden niet van alle 48 patiënten een monster 4 en 5 afgenomen worden. De door de huisarts geregistreerde symptomatologie wordt in tabel 6.4.1 weergegeven. Door de 1838 deelnemers werden 1806 vragenlijsten na de eerste observatieperiode (november en december 1991) en 1756 na de tweede periode (januari tot en met 15 april 1992) geretourneerd. Na toepassing van de ICHPPC-2-defined en de peilstationcriteria bleken 237 respectievelijk 151 patiënten te voldoen aan de criteria voor influenza of influenza-achtige ziekte (tabel 6.4.2 en 6.4.3). De overige gegevens uit deze enquêteformulieren (ziekteduur, symptomatologie en bijwerkingen) worden besproken in de respectievelijke hoofdstukken. 
Tabel 6.4.2 Influenza of influenza-achtige ziekten) (IAZ) volgens ICHPPC-2defined-criteria bij vaccin-respectievelijk placebogroep $(n=1838)$.

\begin{tabular}{|c|c|c|c|}
\hline \multicolumn{4}{|c|}{ Vaccinatie } \\
\hline IAZ & Vaccin & Placebo & Totaal \\
\hline$\overline{\mathrm{Ja}}$ & 108 & 129 & 237 \\
\hline Nee & 811 & 780 & 1591 \\
\hline Totaal & 919 & 909 & 1828 \\
\hline
\end{tabular}

\section{Tabel 6.4.3 Influenza of influenza-achtige ziekten (IAZ) volgens peilstationcriteria} bij vaccin-respectievelijk placebogroep $(n=1838)$.

\begin{tabular}{|c|c|c|c|}
\hline IAZ & & & \\
\hline & Vaccin & Placebo & Totaal \\
\hline $\mathrm{Ja}$ & 62 & 89 & 151 \\
\hline Nee & 857 & 820 & 1677 \\
\hline Totaal & 919 & 909 & 1828 \\
\hline
\end{tabular}





\section{HOOFDSTUK 7}

\section{DE VOORSPELLENDE WAARDE VAN DE SYMPTOMATOLOGIE VAN INFLUENZA}

Th.M.E. Govaert, G.J. Dinant, M.J.W. Sprenger, K. Aretz, J.A. Knottnerus, aangeboden 


\section{SAMENVATTING}

Doel. Het bepalen van het symptomencomplex met de grootste voorspellende waarde voor de diagnose influenza.

Opzet. Enquêtelijstonderzoek met vragen naar de symptomatologie van influenza bij patiënten van 60 jaar en ouder $(n=1838)$ die deelnamen aan een gerandomiseerde, dubbelblinde, placebo-gecontroleerde studie naar de effectiviteit van influenzavaccinatie. De 34 deelnemende huisartsen registreerden de symptomatologie bij patiënten die zich met een influenza-achtig ziektebeeld op hun spreekuur meldden.

Methode. De validiteit van de diagnostische conclusie van de huisarts en die volgens de criteria van de International Classification of Health Problems in Primary Care (ICHPPC-2defined), alsmede de peilstations in Nederland werd bepaald met behulp van de voorspellende waarde en odds ratio, met serologisch bewezen influenza als gouden standaard. Op dezelfde wijze werd nagegaan welk symptomencomplex de grootste voorspellende waarde heeft voor influenza. Door middel van een logistische regressie-analyse werden de uitkomsten geverifieerd.

Resultaten. De voorspellende waarde van de diagnostiek van de huisarts bedroeg $35 \%$ en die volgens de beide classificatiemethoden $24 \%$ (peilstations) en $18 \%$ (ICHPPC-2-defined). Van de individuele symptomen bleken koorts en hoesten de grootste voorspellende waarde te hebben. De combinatie koorts, hoesten en acuut begin had de grootste voorspellende waarde $(30,3 \%)$ voor de diagnose influenza.

Conclusie. Het verdient aanbeveling om de criteria van de ICHPPC-2-defined en de peilstations in Nederland als volgt aan te passen: Influenza is waarschijnlijk indien van het totale symptomencomplex minstens aanwezig zijn koorts, hoesten en acuut begin.

Sleutelwoorden: influenza, diagnostiek, voorspellende waarde 


\section{INLEIDING}

Zolang er nog geen betrouwbare, snelle en eenvoudige laboratoriumtest is voor het stellen van de diagnose influenza of influenza-achtige ziekte (griep) is de huisarts aangewezen op de klinische symptomatologie er van (1). De diagnostische criteria zijn echter niet. eensluidend (2-4). Volgens de criteria van de peilstations in Nederland is een acuut begin (met een prodromaal stadium van hoogstens drie tot vier dagen) en een temperatuur van tenminste $38^{\circ} \mathrm{C}$, rectaal gemeten, obligaat voor influenza of een influenza-achtige ziekte (tabel 7.1)(2). Volgens de criteria van de International Classification of Health Problems in Primary Care (ICHPPC-2-defined) (3), wordt de diagnose influenza gesteld indien 6 van de 9 symptomen

\section{Tabel 7.1 \\ Criteria voor het stellen van de diagnose influenza of influenza-achtige ziekte.}

Volgens de

PEILSTATIONS (2):

Volgens de

ICHPPC-2-defined (3):
1 Een acuut begin, dus hoogstens een prodromaal stadium van drie tot vier dagen (inclusief preëxistente luchtweginfectie op een niet ziekmakend niveau) en

2 de infectie moet gepaard gaan met een temperatuursverhoging: van tenminste $38^{\circ} \mathrm{C}$, rectaal en

3 tenminste een van de volgende symptomen moet aanwezig zijn : hoest, coryza, rauwe keel, frontale hoofdpijn, retrosternale pijn, myalgieën.

Plotseling begin, hoesten, koude rillingen, koorts, algehele malaise, hoofdpijn, myalgieën, rode keel of rhinitis, contact met influenza. Voor het stellen van de diagnose moet voldaan zijn aan tenminste een van de drie volgende criteria:

a viruskweek of serologische bevestiging,

b een influenza epidemie en vier van boven aangehaalde symptomen,

c zes van boven aangehaalde symptomen.

aanwezig zijn (tabel 7.1). Door 102 huisartsen die deelnamen aan de influenzasurveillance in Engeland werd gemeld dat zij de symptomen koude rillingen, malaise, myalgieën en de: aanwezigheid van een influenza-epidemie de belangrijkste criteria vonden (5). Uit een Australisch onderzoek gedurende de jaren 1968-1972 kwam naar voren dat van de symptomen die in de ICHPPC-2-defined vermeld staan, alleen de klacht hoesten obligaat is voor de serologisch bevestigde diagnose (6). Ook bestaat er een interdokter variatie bij het interpreteren van de verschillende criteria. Om deze reden wordt in Frankrijk aan registrerende artsen geadviseerd hun eigen criteria consequent te gebruiken (7). Het is van belang om influenza van influenza-achtige ziekten zoveel als mogelijk te onderscheiden. Influenza leidt tot een kortere ziekteperiode dan influenza-achtige ziekten (8), maar resulteert eerder in ernstige complicaties, met name bij ouderen en risicopatiënten (9-11).

In het kader van een gerandomiseerde, dubbelblinde, placebo- gecontroleerde studie naar de effectiviteit van influenzavaccinatie onder ouderen waren wij in de gelegenheid een onderzoek te doen naar de voorspellende waarde van het symptomencomplex waarop de diagnose influenza of influenza-achtige ziekte gesteld wordt. Hierbij werd serologisch bewezen influenza als gouden standaard gebruikt. 


\section{METHODE}

\section{Patiënten}

Van de 68.988 patiënten uit 15 huisartspraktijken werden alle patiënten die jonger waren dan 60 jaar geëxcludeerd. Tevens werden uitgesloten patiënten die door de huisarts geacht werden te behoren tot een risicogroep volgens het advies van de Gezondheidsraad (12) en patiënten die verbleven in verzorgings- en verpleegtehuizen. De resterende patiënten werden schriftelijk uitgenodigd voor deelname aan het onderzoek. Van de 9907 uitgenodigde personen stemden $1838(18,6 \%)$ in met deelname; 869 mannen $(47,3 \%)$ en 969 vrouwen $(52,7 \%)$. De gemiddelde leeftijd was 67 jaar (standaard deviatie 6; mediaan 66) en de range liep van 60 tot 91 jaar. Zevenentwintig procent bleek alsnog cardiologische, pulmonale of stofwisselingsproblemen te hebben. Deze was naar het oordeel van de huisarts echter niet van dien aard dat vaccinatie was aangewezen. Bij de deelnemende huisartsen bleek er een verschillende interpretatie te zijn van het begrip risicopatient. Om de invloed van de potentiële risicostatus op de voorspellende waarde van de diverse symptomen van influenza te beoordelen werden de deelnemers ingedeeld in de volgende categorieën: patiënten met hartaandoeningen, longaandoeningen, diabetes mellitus en deelnemers met andere of geen aandoeningen.

\section{Procedure}

Tussen 1 en 15 november 1991 ontvingen alle deelnemers een injectie met vaccin of placebo. Voorafgaande aan de injectie (S1), drie weken later (S2) en aan het eind (S3) van de onderzoekperiode (april 1992) werd een veneus bloedmonster van alle deelnemers afgenomen. Als vaccin werd gebruikt het gezuiverd split-vaccin geproduceerd door Evans Medical Ltd, Langhurst, Horsham, England. Dit vaccin was, evenals de andere in Nederland verkrijgbare griepvaccins, samengesteld volgens de richtlijnen van de World Health Organisation en de Gezondheidsraad. Als placebo werd fysiologisch zout gebruikt. Het vaccin of placebo werd door drie ervaren huisartsen intramusculair in de linker of rechter musculus deltoideus toegediend. In totaal ontvingen 927 patiënten (420 mannen en 507 vrouwen) vaccin en 911 ( 449 mannen en 462 vrouwen) placebo.

Aan de deelnemende huisartsen werd gevraagd gedurende de onderzoekperiode bij patiënten die zich meldden met verschijnselen van griep de relevante symptomen op een voorgedrukt formulier te registreren. Tijdens dit contact en drie weken later werd zo mogelijk een bloedmonster afgenomen (S4 en S5) om een tussentijdse titerstijging van antilichamen tegen influenza te kunnen objectiveren. Deze sera werden op dezelfde manier behandeld als de monsters 1,2 en 3 . Aan de deelnemers werd gevraagd aan het einde van de eerste (1 november 1991 tot 1 januari 1992) en tweede (1 januari 1992 tot 15 april 1992) observatieperiode een enquête in te vullen met vragen betreffende het eventueel doorgemaakt hebben van een griepepisode en de symptomen die zich hierbij voordeden. Ook tussentijds konden de deelnemers een vragenlijst opsturen indien zij meenden griep te hebben doorgemaakt.

De bepaling van de antilichaamtiter in de sera werd na afloop van de onderzoekperiode uitgevoerd volgens standaardmethoden (13-15).

\section{Diagnestische criteria}

Een titer $\geq 38$ en een viervoudige titerstijging in S3 ten opzichte van S2, of van S5 ten opzichte van \$4, werd bewijzend geacht voor het doorgemaakt hebben van influenza (16). Aan de huisartsen werd gevraagd de criteria van de ICHPPC-2-defined toe te passen bij patiënten die zich bij hen presenteerden met verschijnselen van griep. Echter, hun eigen oordeel prevaleerde.

De criteria van de peilstations in Nederland (2) en die waarmee met behulp van de ICHPPC-2-defined (3) de diagnose influenza of influenza-achtige ziekte wordt gesteld 
werden gebruikt voor het evalueren van de door de deelnemers ingevulde enquêtelijsten.

\section{Data analyse}

Omdat niet gegarandeerd kon worden dat meerdere griepepisodes bij één patiënt onafhankelijk van elkaar gescoord werden, is van de deelnemers die op meer dan één vragenlijst symptomen van griep hadden vermeld slechts dat formulier in de analyse betrokken waarvan de betreffende periode van ziek zijn het dichtst lag bij de periode van epidemische verheffing van griep in de studieperiode.

De validiteit van de diagnose influenza of influenza-achtige ziekte volgens huisarts, ICHPPC-2-defined en peilstationcriteria werd bestudeerd met behulp van de serologie als gouden standaard voor de diagnose influenza. Door het bepalen van sensitiviteit, specificiteit, voorspellende waarde en odds ratio werd het onderscheidend vermogen van de individuele symptomen en diverse symptoomcomplexen voor de diagnose influenza bepaald. Door middel van een multipele logistische regressie-analyse werden de uitkomsten geverifieerd. Daarbij werden als onafhankelijke variabelen alle voor griep relevante symptomen, vaccinatie- en potentiële risicostatus, geslacht en leeftijd gebruikt en als afhankelijke variabele werd de serologische uitkomst gehanteerd.

De analyses werden verricht op een VAX-mainframe computer, met behulp van het programma BMDP.

\section{Goedkeuring medisch ethische commissie}

Het protocol werd goedgekeurd door de medisch-ethische commissie van de Rijksuniversiteit Limburg en het Academisch Ziekenhuis Maastricht. Door alle deelnemers werd een "informed consent" ondertekend.

\section{Tabel 7.2 Samenstelling onderzoekpopulatie naar vaccinatie- en potentiële risicostatus, geslacht en leeftijd ( $n=1838$ ).}

\begin{tabular}{lrr}
\hline & $\mathrm{n}$ & $\%$ \\
\hline $\begin{array}{l}\text { Vaccinatiestatus } \\
\text { Vaccin }\end{array}$ & 927 & \\
Placebo & 911 & 50,4 \\
& & \\
Potentiële risicostatus & 490,6 \\
$\quad$ Aanwezig & 1348 & 26,7 \\
Niet aanwezig & & 73,3 \\
Geslacht & 869 & \\
Man & 969 & \\
Vrouw & & 57,3 \\
& & \\
Leeftijd & & \\
(in jaren) & 764 & 41,6 \\
$60-64$ & 530 & 28,8 \\
$65-69$ & 353 & 19,2 \\
$70-74$ & 127 & 6,9 \\
$75-79$ & 48 & 2,6 \\
$80-84$ & 16 & 0,9 \\
$\geq 85$ & & \\
\hline
\end{tabular}




\section{RESULTATEN}

De samenstelling van de onderzoekpopulatie wordt getoond in tabel 7.2. Het aantal gevaccineerden en niet gevaccineerden was nagenoeg gelijk verdeeld in de verschillende subgroepen.

Door de deelnemers werden na de eerste observatieperiode 1806 vragenlijsten geretourneerd. In de tweede observatieperiode waren dit er 1756. Door 62 deelnemers werden tweemaal en door 11 andere deelnemers driemaal symptomen van een griepepisode gemeld. In totaal werden 645 vragenlijsten waarop de deelnemers klinische symptomen hadden aangekruist in de analyse betrokken. Aan de hand hiervan werd 281 keer influenza of een influenza-achtige ziekte vastgesteld. Influenza werd 121 maal serologisch bevestigd.

Tabel 7.3 Sensitiviteit (Se), specificiteit (Sp), positief (VW+) en negatief (VW-) voorspellende waarde en odds ratio (OR), inclusief betrouwbaarheidsinterval (BI), van de klinisch gestelde diagnose influenza of influenzaachtige ziekte volgens de huisarts, de criteria van de peilstations en de International Classification of Health Problems in Primary Care (ICHPPC-2-defined), met serologisch bewezen influenza ( $n=121$ ) als gouden standaard.

\begin{tabular}{lrrrrrrr}
\hline $\begin{array}{l}\text { Influenza of } \\
\text { influenza-achtige } \\
\text { ziekte }\end{array}$ & $\mathrm{n} *$ & $\mathrm{Se}$ & $\mathrm{Sp}$ & $\mathrm{VW}+$ & $\mathrm{VW}-$ & $\mathrm{OR}$ & $95 \% \mathrm{BI}$ \\
\hline Huisarts & 48 & $\mathrm{nvt}^{* *}$ & $\mathrm{nvt}^{* *}$ & 35 & $\mathrm{nvt}^{* *}$ & 8,6 & $4,6-16,1$ \\
Peilstations & 161 & 29 & 94 & 24 & 95 & 5,8 & $3,8-9,1$ \\
ICHPPC-2-defined & 266 & 35 & 89 & 18 & 95 & 4,1 & $2,8-6,2$
\end{tabular}

* n: aantal gevallen van influenza of influenza-achtige ziekten volgens de diverse criteria **nvt: niet van toepassing (de huisarts beoordeelt alleen de hem tijdens het spreekuur aangeboden populatie)

Tabel 7.4 Sensitiviteit (Se), specificiteit (Sp), positief (VW+) en negatief (VW-) voorspellende waarde en odds ratio (OR), inclusief betrouwbaarheidsinterval (BI), van symptomen voor de serologisch bewezen diagnose influenza $(n=121)$.

\begin{tabular}{llllrrrrr}
\hline Symptoom & $\mathrm{n} *$ & $\mathrm{Se}$ & $\mathrm{Sp}$ & $\mathrm{VW}+$ & $\mathrm{VW}-$ & $\mathrm{OR}$ & $95 \% \mathrm{BI}$ \\
\hline Hoesten & 456 & 66 & 76 & 17 & 97 & 6,2 & $4,15-9,23$ \\
Koorts & 187 & 34 & 91 & 21 & 95 & 5,0 & $3,28-7,63$ \\
Acuut begin & 335 & 51 & 81 & 16 & 96 & 4,2 & $2,83-6,31$ \\
Malaise & 428 & 57 & 77 & 16 & 96 & 4,6 & $3,13-6,75$ \\
Koude rillingen & 358 & 47 & 81 & 15 & 95 & 3,7 & $2,52-5,46$ \\
Myalgieën & 374 & 45 & 80 & 14 & 95 & 3,3 & $2,25-4,84$ \\
Hoofdpijn & 399 & 44 & 78 & 13 & 95 & 2,9 & $1,97-4,24$ \\
Keelpijn & 365 & 40 & 80 & 13 & 95 & 2,7 & $1,83-3,99$
\end{tabular}

* $n$ : totaal aantal meldingen van het betreffende symptoom 
De huisartsen meldden 48 gevallen van influenza of een influenza-achtige ziekte waarbij 17 maal influenza serologisch werd bewezen. Daarbij stonden de volgende symptomen op de voorgrond: malaise ( 45 keer), koorts ( 43 keer), hoesten ( 42 keer) en acuut begin ( 38 keer). Met gebruikmaking van de ICHPPC-2-defined criteria werden 266 gevallen van influenza of een influenza-achtige ziekte gevonden. Hierbij werd 41 maal influenza serologisch bewezen. Volgens criteria van de peilstations werden 161 gevallen van influenza of influenzaachtige ziekten gevonden waarbij 35 maal influenza serologisch werd aangetoond. Het onderscheidend vermogen van de conclusies van de huisarts en die volgens ICHPPC-2-defined en peilstationcriteria wordt getoond in tabel 7.3. Hieruit blijkt dat de peilstationcriteria beter scoren dan die van de ICHPPC-2-defined. De sensitiviteit, specificiteit, voorspellende waarde en odds ratio van de diverse symptomen waarop de diagnose influenza kan worden gesteld worden getoond in tabel 7.4. De voorspellende waarde van de symptomen koorts en hoesten stonden hierbij op de voorgrond. Uit de logistische regressie-analyse kwamen dezelfde symptomen als statistisch significante voorspellers van serologisch bewezen influenza naar voren (tabel 7.5). Uit tabel 7.6 blijkt dat naarmate meer symptomen aanwezig zijn

\begin{tabular}{|c|c|c|c|c|c|c|c|}
\hline \multirow[t]{2}{*}{ Tabel 7.5} & \multicolumn{7}{|c|}{$\begin{array}{l}\text { Multipele logistische regressie-analyse met als onafhankelijke } \\
\text { variabelen alle voor griep relevante symptomen, vaccinatie- en } \\
\text { potentiële risicostatus, geslacht en leeftijd en als afhankelijke variabele } \\
\text { bevestigde serologisch influenza. Getoond zijn het volledig model en het } \\
\text { gereduceerde model met alleen de statistisch significante uitslagen. }\end{array}$} \\
\hline & & & Volledig mode & & & reduceerd $\mathrm{mc}$ & odel \\
\hline $\begin{array}{l}\text { Onafhankelijke } \\
\text { variabelen }\end{array}$ & ke code & OR & $95 \%$ B 1 & p-waarde & OR & $95 \%$ B 1 & p-waarde \\
\hline Hoesten & $\begin{array}{r}\mathrm{ja}=1 \\
\mathrm{nee}=0\end{array}$ & 7,29 & $(3,31-16,1)$ & $<0,001$ & 5,25 & $(3,28-8,39)$ & $<0,001$ \\
\hline Koorts & $\begin{array}{r}\mathrm{ja}=1 \\
\mathrm{nee}=0\end{array}$ & 2,30 & $(1,31-4,04)$ & 0,005 & 2,18 & $(1,33-3,57)$ & 0,002 \\
\hline Acuut begin & $\begin{array}{r}\text { ja }=1 \\
\text { nee }=0\end{array}$ & 0,95 & $(0,51-1,77)$ & 0,881 & & & \\
\hline Malaise & $\begin{array}{r}j a=1 \\
\text { nee }=0\end{array}$ & 1,27 & $(0,57-2,82)$ & 0,571 & & & \\
\hline Koude rillinge & en $\begin{array}{r}j a \\
\text { nee }=0\end{array}$ & 1,05 & $(0,57-1,93)$ & 0,880 & & & \\
\hline Myalgieën & $\begin{array}{r}\text { ja }=1 \\
\text { nee }=0\end{array}$ & 0,90 & $(0,48-1,69)$ & 0,745 & & & \\
\hline Hoofdpijn & $\begin{array}{r}\mathrm{ja}=1 \\
\mathrm{nee}=0\end{array}$ & 0,66 & $(0,36-1,20)$ & 0,178 & & & \\
\hline Keelpijn & $\begin{array}{r}\mathrm{ja}=1 \\
\text { nee }=0\end{array}$ & 0,74 & $(0,43-1,30)$ & 0,312 & & & \\
\hline Risicogroep & $\begin{array}{r}\mathrm{ja}=1 \\
\text { nee }=0\end{array}$ & 0,88 & $(0,54-1,44)$ & 0,619 & & & \\
\hline Vaccin/placebc & $\begin{array}{r}\text { ja }=1 \\
\text { nee }=0\end{array}$ & 0,56 & $(0,36-0,86)$ & 0,009 & 0,56 & $(0,36-0,86)$ & 0,009 \\
\hline Geslacht & $\begin{array}{r}\operatorname{man}=1 \\
\text { vrouw }=0\end{array}$ & 0,97 & $(0,63-1,51)$ & 0,908 & & & \\
\hline Leeftijd & per jaar & 1,01 & $(0,97-1,05)$ & 0,702 & & & \\
\hline Constante & & 0,026 & $0,0018-0,37)$ & 0,008 & 0,041 & $0,028-0,059)$ & $<0,001$ \\
\hline
\end{tabular}


de voorspellende waarde van het complex toeneemt. Bepaalde combinaties van symptomen (koorts en hoesten; koorts, hoesten en acuut begin; koorts, hoesten, acuut begin en malaise) hebben zelfs een grotere voorspellende waarde dan het aanwezig zijn van alle symptomen. Indien de combinatie koorts, hoesten en acuut begin door de huisartsen gebruikt zou zijn bij het stellen van de diagnose influenza, zou dit symptomencomplex een voorspellende waarde bereikt hebben van $44 \%$ (betrouwbaarheidsinterval $30 \%-58 \%$ ).

Tabel 7.6 Positief voorspellende waarde (weergegeven als percentage positieve
serologie) en odds ratio (OR), met betrouwbaarheidsinterval (BI), van
diverse combinaties van gemelde symptomen in de onderzoekpopulatie
( $\mathrm{n}=1791$ ) met serologisch bewezen influenza ( $\mathrm{n}=121$ ) als gouden
standaard.

\section{Combinaties van}

symptomen

n* $\begin{gathered}\% \\ \text { positieve } \\ \text { serologie }\end{gathered}$

\begin{tabular}{lrrrr}
\hline 0 & 1155 & $3,2^{* *}$ & & \\
1 & 75 & 6,7 & 0,99 & $0,39-2,49$ \\
2 & 70 & 5,7 & 0,83 & $0,30-2,32$ \\
3 & 52 & 15,4 & 2,62 & $1,20-5,69$ \\
4 & 92 & 10,8 & 1,74 & $0,88-3,46$ \\
5 & 112 & 13,4 & 2,29 & $1,29-4,09$ \\
6 & 89 & 16,9 & 3,05 & $1,69-5,50$ \\
7 & 99 & 15,2 & 2,76 & $1,49-4,79$ \\
8 & 47 & 25,5 & 5,14 & $2,60-10,20$ \\
\hline Totaal & 1791 & $6,8 * *$ & & \\
& & & & \\
koorts en acuut begin & 144 & 24,3 & 5,83 & $3,76-9,03$ \\
koorts en hoesten & 137 & 26,3 & 5,68 & $4,24-10,20$ \\
koorts, hoesten en acuut begin & 109 & 30,3 & 7,87 & $4,96-12,50$ \\
koorts, hoesten, acuut begin en malaise & 105 & 29,5 & 7,43 & $4,64-11,90$ \\
\hline
\end{tabular}

* $\mathrm{n}$ : totaal aantal personen met betreffende symptoom of symptomen

** $\mathrm{n}$ : in de totale populatie, respectievelijk in de subgroep serologisch influenza zonder symptomen, geeft dit percentage de prior kans op het krijgen van influenza weer.

\section{BESCHOUWING}

De relatief lage positief voorspellende waarde van het symptoomcomplex koorts, hoesten en acuut begin $(30 \%)$ levert, indien vergeleken met de prior kans op serologisch bewezen influenza (prevalentie) van $7 \%(121 / 1838)$, toch nog een netto winst aan diagnostische zekerheid van $23 \%(30 \%-7 \%$ ) en een percentage winst aan zekerheid van $328 \%$ (23\%/7\%) (17). Dit betekent dat indien een patiënt denkt griep te hebben, dit vermoeden meer dan 4 maal $(30 \% / 7 \%)$ zekerder wordt indien hij koorts heeft, hoest en de klachten acuut beginnen. De voorspellende waarde zal nog hoger zijn in de subpopulatie die zich met de betreffende klachten bij de huisarts meldt. Dit wordt geillustreerd door het verschil tussen de positief voorspellende waarde van het complex vastgesteld op basis van de enquêtelijstgegevens 
(30\%) en de positief voorspellende waarde van hetzelfde complex indien de patiënt zich presenteert bij de huisarts (44\%). De diagnose van de huisarts zal vooral tijdens een epidemie een grotere voorspellende waarde hebben.

Dat de voorspellende waarde van de combinatie koorts, hoesten en acuut begin groter is dan die van alle symptomen tezamen wil zeggen dat bij alle symptomen tezamen er een grotere kans bestaat op het diagnostiseren van een influenza-achtige ziekte dan van influenza.

De voorspellende waarde van de diagnostische conclusie van de huisarts is voor de spreekuurpopulatie groter dan die volgens de criteria van de peilstations of de ICHPPC-2-defined, gesteld aan de hand van enquêtelijsten. Immers, de huisarts heeft het voordeel van de grotere prior kans op influenza bij patiënten die hem wegens het vermoeden op griep consulteren in tegenstelling tot de ongeselecteerde populatie waartoe de deelnemers die een formulier invulden behoorden. Bovendien zal de huisarts op grond van zijn ervaring het diagnostische gewicht van de symptomen wellicht beter schatten dan de patiënt. Vertekening van de bevindingen doordat de patiënt pas aan het einde van een onderzoekperiode de formulieren hoefde in te vullen, is niet uit te sluiten. Uit andere, deels vergelijkbare studies blijkt echter dat de informatie die de patiënt verstrekt in het algemeen betrouwbaar is $(18,19)$. Bovendien is het niet op voorhand duidelijk in welke richting deze vertekening werkt. Patiënten kunnen vergeten zijn van welke symptomen zij hinder hadden, terwijl ook een onterecht scoren van de symptomen mogelijk is.

Het symptomencomplex koorts, hoesten en acuut begin bereikt in onze onderzoekpopulatie een hogere voorspellende waarde dan de criteria van de peilstations en ICHPPC-2-defined en zou daarom voor de klinische diagnose de voorkeur verdienen. Echter men moet zich wel realiseren dat ook bij aanwezigheid van dit symptomencomplex meer dan de helft van de patiënten serologisch geen griep heeft. 


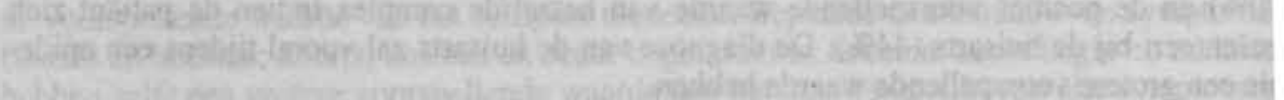 \\ LITERATUUR \\ 1 Pachucki CT. The diagnosis of influenza. Semin Resp Infect 1992; 7: 46-53 \\ 2 Pel JZS. Proefonderzoek naar de frequentie en de etiologie van griepachtige ziekten in de winter 1963-1964. Huisarts Wet 1965; 8: 321-24 \\ 3 Classification Committee of Wonca. ICHPPC-2-defined. Inclusion criteria for the use of the rubrics of the International Classification of Health Problems in Primary Care. Oxford: Oxford University Press, 1983 \\ 4 Lamberts H, Wood M. International Classification of Primary Care. Oxford: Oxford University Press, 1983 \\ 5 Fleming DM, Ayres JG. Diagnosis and patterns of incidence of influenza, influenza-like illnes and the common cold in general practic. J Roy Coll Gen Pract 1988; 38: 159-62 \\ 6 Gill PW, Murphy AM. The diagnosis of influenza. Aust Fam Phys 1991; 11: 1664-65 \\ 7 Hannoun C, Dab W, Cohen JM. A new influenza surveillance system in France: the lle-de- France "Grog". 1. Principles and Methodology. Eur J Epidemiol 1989; 5: 285-93 \\ 8 Govaert ThME, Dinant GJ, Knottnerus JA, De duur van influenza en influenza-achtige ziekten bij ouderen (geaccepteerd door Huisarts Wet) \\ 9 Govaert ThME, Dinant GJ, Aretz K, Masurel N, Sprenger MJW, Knottnerus JA. Adverse reactions to influenza vaccine in elderly people: randomised double blind placebo controlled trial. Br Med J 1993; 307: $988-90$ \\ 10 Barker WH, Mullooly JP. Pneumonia and influenza deaths during epidemics. Implications for prevention. Arch Intern Med 1982; 142: 85-89 \\ 11 Sprenger MJW. The impact of influenza: an epidemiological study of morbidity, direct mortality and related mortality [Thesis]. Rotterdam: Erasmus Universiteit, 1990 \\ 12 Gezondheidsraad: Commissie vaccinatie tegen influenza. Vaccinatie tegen influenza; seizoen 1991-1992. Den Haag: Gezondheidsraad, 1991/15 \\ 13 Palache AM, Beyer WEP, Sprenger MJW, Masurel N, Jonge S de, Vardy A, et al. Antibody response after influenza immunization with various vaccine doses: a double blind, placebo controlled, multi-centre, dose-response study in elderly nursing home residents and young volunteers. Vaccine 1993; 11: 3-9 \\ 14 Masurel N, Ophof B, Jong P de. Antibody respons to immunization with influenza AUSSR/77 (H1N1) virus in young individuals primed or unprimed for ANew Jersey/76(H1N1) virus. J Hyg 1981; 87: 201.09 \\ 15 Berlin BS, MCQueen JL, Minuse E, Davenport FM. A method for increasing the sensitivity of the haemagglutination-inhibition test with equine influenza virus. Virology' 1963; 21: 665-67 \\ 16 Pyhâlá $\mathrm{A}$, Kleemola $M$. The value of complement fixation and haemagglutination inhibition tests in the diagnosis of influenza A. Acta Virol 1976; 20:66i-69 \\ 17 Connel FA, Koepsell TD. Measures of gain in certainty from a diagnostic test. Am J Epidemiol 1985; 121: $744-53$ \\ 18 Tellnes G. Days lost by sickness certification. Scan J Prim Health Care 1989; 7: 245-51 \\ 19 Tellness G. Sickness certification in general practice: a review. Fam Pract 1989; 6: 58-65}




\section{HOOFDSTUK 8}

\section{DE DUUR VAN INFLUENZA-ACHTIGE ZIEKTEN BIJ OUDEREN}

Th.M.E. Govaert, J.A. Knottnerus, G.J. Dinant, M.J.W. Sprenger, N. Masurel.

geaccepteerd voor publicatie in Huisarts Wet 


\section{SAMENVATTING}

Doel. Het bepalen van de ziekteduur en duur van onderbreking van dagelijkse activiteiten ten gevolge van influenza en influenza-achtige ziekten (griep), en determinanten hiervan, bij ouderen.

Opzet. Gerandomiseerd onderzoek bij patiënten met griep, geïdentificeerd met behulp van vragenlijsten en serologie.

Methode. Onder 1838 personen van 60 jaar en ouder werden 281 griep-episodes gevonden. Middels een vragenlijst werd nagegaan hoeveel dagen men ziek was en hoeveel dagen men zijn dagelijkse werkzaamheden niet kon uitoefenen. Als determinanten werden onderzocht de vaccinatiestatus, potentiële risicostatus, het geslacht en de leeftijd van de patiënt, alsmede het serologisch wel of niet bewezen zijn van influenza.

Resultaten. De patiënten waren gemiddeld 7 dagen ziek tengevolge van influenza-achtige ziekten en gemiddeld 5 dagen tengevolge van influenza. Ze onderbraken gemiddeld gedurende 4 dagen hun dagelijkse bezigheden. Gevaccineerden en niet gevaccineerden, potentiële risicodragers en niet risicodragers, mannen en vrouwen, en grieppatiënten waarbij de serologie van influenza positief of negatief was, toonden wat betreft de periode van ziek zijn en de periode van werkonderbreking geen statistisch significant verschil. Deelnemers van 70 jaar en ouder hadden een kortere periode van onderbreking van hun dagelijkse bezigheden dan de deelnemers van 60 jaar tot en met 69 jaar.

Conclusie: De ziekteduur tengevolge van influenza is korter dan tengevolge van influenzaachtige ziekten. De ziekteduur en duur van werkonderbreking wordt niet significant beïnvloed door de vaccinatie- en risicostatus en het geslacht van de patiënt. Ook wordt geen steun gevonden voor de opvatting dat de ziekteduur ten gevolge van griep stijgt met het ouder worden.

Sleutelwoorden: influenza, ouderen, ziekteduur 


\section{INLEIDING}

Over ziekteduur bij oudere mensen tengevolge van influenza of influenza-achtige ziekten (IAZ) is weinig bekend.

Ziekteduur en het arbeidsverzuim ten gevolge van IAZ worden in Nederland veelal niet separaat geregistreerd (1-3). Enige informatie leveren de jaarlijkse cijfers van bedrijfsverenigingen en het Centraal Bureau voor de Statistiek (CBS) (4). In de CBS-verslagen van 1992 en '93 werd opgegeven dat de gemiddelde verzuimduur ten gevolge van influenza in de jaren 1989 en ' 90 voor mannen 14,0 respectievelijk 14,6 en voor vrouwen 13,5 respectievelijk 14,0 dagen bedroeg.

Internationale literatuur over dit onderwerp is schaars voorhanden en beperkt zich voornamelijk tot gegevens bij werknemers (5-9). Tellnes constateerde een toename van de ziekteduur met het vorderen der leeftijd $(5,6)$.

Oudere mensen zouden een minder goed functionerend immuunsysteern hebben en daardoor meer vatbaar zijn voor influenza (10-12). Niet iedereen deelt deze mening (13). Voor de huisarts is het relevant hoe lang oudere mensen ziek zijn tengevolge van influenza. Indien een ouder iemand langer ziek is dan het gemiddelde dat hiervoor staat moet de arts bedacht zijn op een IAZ of een complicatie tengevolge van influenza.

Wij onderzochten de volgende vraagstellingen:

- Hoelang kunnen ouderen tengevolge van influenza of een influenza-achtige ziekte hun dagelijkse bezigheden niet verrichten en hoeveel dagen voelen zij zich ziek?

- In welke mate zijn vaccinatie- en risicostatus, leeftijd, geslacht en het serologisch al dan niet bevestigd zijn van de diagnose van invloed op de duur van het ziek zijn en de onderbreking van de dagelijkse bezigheden (verder te noemen werkonderbreking)?

\section{METHODE}

\section{Patiënten}

Van de 68.988 patiënten uit 15 huisartspraktijken werden alle patiënten die jonger waren dan 60 jaar geëxcludeerd. Tevens werden uitgesloten patiënten die door de huisarts geacht werden te behoren tot een risicogroep volgens het advies van de Gezondheidsraad (14), en patiënten die verbleven in verzorgings- en verpleegtehuizen. De resterende patiënten werden schriftelijk uitgenodigd voor deelname aan het onderzoek. Van de 9907 uitgenodigde personen stemden $1838(18,6 \%)$ in met deelname. Zevenentwintig procent van de deelnemers bleek alsnog cardiologische, pulmonale, of stofwisselings problematiek te hebben. Deze was naar het oordeel van de huisarts echter niet van dien aard dat vaccinatie was aangewezen. Om de invloed van de potentiële risicostatus op de ziekteduur en duur van werkonderbreking te beoordelen werden deze deelnemers ingedeeld in de volgende categorieën: patiënten met hartaandoeningen, longaandoeningen, diabetes mellitus en deelnemers met andere of geen aandoeningen.

\section{Procedure en laboratoriumbepalingen}

Tussen 1 en 15 november 1991 ontvingen alle deelnemers een injectie met vaccin of placebo volgens een gestratificeerd randomisatieschema. Er werden vier strata geformeerd volgens de bovengenoemde categorieën van aandoeningen. Als vaccin werd gebruikt een gezuiverd split-vaccin geproduceerd door Evans Medical Ltd, Langhurst, Horsham, England. Dit vaccin was, evenals de andere in Nederland verkrijgbare griepvaccins, samengesteld volgens de richtlijnen van de World Health Organisation en de Gezondheidsraad. Als placebo werd fysiologisch zout gebruikt. Voorafgaande aan de injectie (S1), drie weken later (S2) en aan het eind (S3) van de onderzoekperiode (april 1992) werd een veneus bloedmonster van alle deelnemers afgenomen. 
Aan de deelnemers werd gevraagd aan het eind van de eerste (1 november 1991 tot 1 januari 1992) en tweede ( 1 januari 1992 tot 15 april 1992) observatieperiode een enquête in te vullen met vragen betreffende het eventueel doorgemaakt hebben van een griepepisode en de periode dat men ziek was geweest, c.q. zijn dagelijkse bezigheden had moeten onderbreken. Ook tussentijds konden de deelnemers een vragenlijst opsturen indien zij meenden griep te hebben.

De bepaling van de antilichaamtiter in de sera werd uitgevoerd met behulp van de hemagglutinatie remmingstest $(15,16)$.

\section{Diagnostische criteria}

Aan de hand van de door de deelnemers ingevulde vragenlijsten werd, door toepassing van de criteria van de International Classification of Health Problems in Primary Care (ICHPPC-2-defined) $(17,18)$ en de criteria zoals deze gebruikt worden door de peilstations in Nederland (19), bepaald wie van de deelnemers influenza of een influenza-achtige ziekte had doorgemaakt.

Een viervoudige titerstijging én een titer $\geq 38$ in S3 ten opzichte van S2 werd bewijzend geacht voor het doorgemaakt hebben van influenza (20).

\section{Data analyse}

Omdat niet gegarandeerd kon worden dat meerdere griepepisodes bij één patiënt onafhankelijk van elkaar gescoord werden, is van de deelnemers die op meer dan één vragenlijst symptomen van griep hadden vermeld slechts dat formulier in de analyse betrokken waarvan de betreffende periode van ziek zijn het dichtst lag bij de periode van epidemische verheffing van griep in de studieperiode. Door middel van de Mann-Whitney toets voor numerieke variabelen en de Kruskal-Wallis toets voor onafhankelijke proporties werd bestudeerd of er een statistisch significant verschil was in ziekteduur en tijd van werkonderbreking tussen gevaccineerde en niet gevaccineerde grieppatiënten, risico- en niet risicopatiënten, mannen en vrouwen en tussen de leeftijdsgroepen $60-69$ jaar en $\geq 70$ jaar. Tevens werd met behulp van een multipele lineaire regressie-analyse bepaald in hoeverre de onafhankelijke variabelen vaccinatie- en risicostatus, geslacht en leeftijd van invloed waren op de afhankelijke variabelen ziekteduur en dagen van werkonderbreking. Wegens de scheve verdeling van ziekteduur en dagen van werkonderbreking werden de data logaritmisch getransformeerd. Omdat in een aantal gevallen de gemelde ziekteduur 0 dagen was, werd alvorens de logaritme te nemen, bij de afhankelijke variabele telkens 1 opgeteld. Deze analyses werden uitgevoerd voor zowel de deelnemers die een influenza-achtige ziekte hadden doorgemaakt, als de deelnemers met een influenza-achtige ziekte waarbij de diagnose influenza serologisch was bevestigd. De analyses werden verricht op een VAX-mainframe computer, met behulp van het BMDP-programma versie 1990 (21).

\section{Goedkeuring medisch ethische commissie}

Het protocol is goedgekeurd door de medisch-ethische commissie van de Rijksuniversiteit Limburg en het Academisch Ziekenhuis Maastricht. Door alle deelnemers is een informed consent ondertekend.

\section{RESULTATEN}

De samenstelling van de deelnemers aan de trial wordt getoond in tabel 8.1. Het aantal gevaccineerden en niet gevaccineerden was nagenoeg gelijk verdeeld, ook in de subgroepen risicopatiënten, mannen, vrouwen en leeftijd. Door de deelnemers zijn na de eerste observatieperiode 1806 vragenlijsten geretourneerd. In de tweede observatieperiode waren er dit 1756. Alle geretourneerde lijsten waren bruikbaar. Door 62 deelnemers werd tweemaal en 
door 11 andere deelnemers driemaal een formulier ingevuld met meldingen van griep of symptomen hiervan. Aan de hand van de vragenlijsten zijn 281 gevallen van influenza of influenza-achtige ziekte vastgesteld. Het gemiddelde aantal dagen van ziekteduur en werkonderbreking bedroeg 6,7 respectievelijk 3,8 dagen bij deelnemers waarbij de diagnose op klinische gronden werd gesteld en 5,3 respectievelijk 3,5 dagen indien de klinische diag-

Tabel 8.1 Samenstelling onderzoekpopulatie naar vaccinatie- en risicostatus, geslacht en leeftijd ( $\mathrm{n}=1838)$.

\begin{tabular}{lrr} 
& $\mathbf{n}$ & $\%$ \\
\hline Vaccinatiestatus & 927 & \\
Vaccin & 911 & 50,4 \\
Placebo & & 49,6 \\
& & \\
Potentiële risicostatus & 490 & 26,7 \\
Aanwezig & 1348 & 73,3 \\
Niet aanwezig & & \\
Geslacht & 869 & 47,3 \\
Man & 969 & 52,7 \\
Vrouw & & \\
& & \\
Leeftijd & & \\
(in jaren) & 764 & 28,6 \\
$60-64$ & 530 & 19,2 \\
$65-69$ & 353 & 6,9 \\
$70-74$ & 127 & 2,6 \\
$75-79$ & 48 & 0,9 \\
$80-84$ & 16 & \\
$\geq 85$ & &
\end{tabular}

Tabel 8.2 Het gemiddelde (gem), de range en percentielen (P25, P50, P75) van de ziekteduur en periode van onderbreking der dagelijkse bezigheden (werkonderbreking), uitgedrukt in dagen, bij alle deelnemers met een influenza-achtige ziekte (IAZ) ( $\mathrm{n}=281$ ) en de subgroep deelnemers mett een influenza-achtige ziekte waarbij de diagnose influenza serologisch werd bevestigd (IAZ/SER) ( $\mathrm{n}=54)$.

\begin{tabular}{|c|c|c|c|c|c|c|c|}
\hline & & $n$ & gem & range & P25 & P50 & P75 \\
\hline \multirow{3}{*}{$\mathrm{IAZ} *$} & ziekteduur & \multirow{3}{*}{279} & 6,7 & $0-60$ & 1 & 5 & 10 \\
\hline & periode van & & & & & & \\
\hline & werkonderbreking & & 3,8 & $0-34$ & 0 & 1 & 6 \\
\hline \multirow{3}{*}{ IAZ/SEF } & ziekteduur & \multirow{3}{*}{54} & 5,3 & $0-27$ & 0 & 2 & 8 \\
\hline & & & & & & & \\
\hline & werkonderbreking & & 3.5 & $0-14$ & 0 & 1 & 7 \\
\hline
\end{tabular}


Tabel 8.3 Ziekteduur en periode van onderbreking der dagelijkse bezigheden bij patiènten met influenza of een influenza-achtige ziekte $(\mathrm{n}=281)$ naar vaccinatie- en potentiële risicostatus, geslacht en leeftijd .

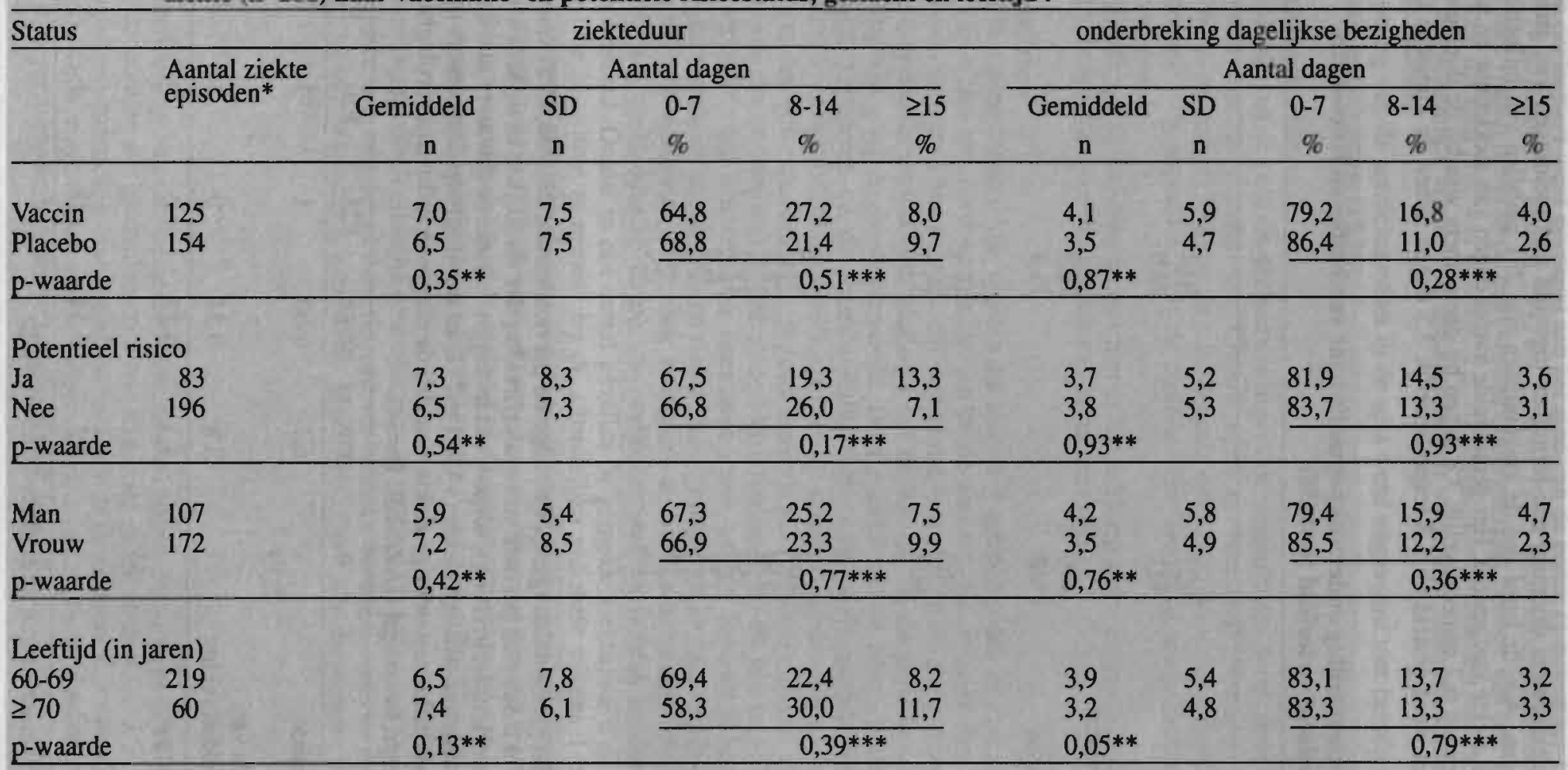

deelnemers waarvan de gegevens niet compleet waren zijn niet meegeteld.

p-waarde: ** getoetst met behulp van de Mann-Whitneytoets *** getoetst met behulp van de Kruskal- Wallistoets 
nose serologisch werd bevestigd (tabel 8.2). Dit verschil was statistisch niet significant $(\mathrm{p}=0,08$ voor de ziekteduur). Wegens de grote spreiding van het aantal dagen dat werd opgegeven voor ziekteduur en werkonderbreking werden ook de kwartielen vermeld. In tabel 8.3 worden voor de diverse subgroepen de ziekteduur en de periode van werkonderbreking getoond. Het gemiddelde aantal dagen van werkonderbreking was voor alle subgroepen duidelijk minder dan het totale aantal dagen dat men zich ziek voelde.

Tussen beide categorieën van iedere variabele blijkt statistisch geen significant verschil te zijn in ziekteduur en periode van werkonderbreking behalve voor de variabele leeftijd. Deelnemers van 70 jaar en ouder met influenza-achtige ziektebeelden blijken eerder hun dagelijkse bezigheden te kunnen hervatten dan de deelnemers van 60 tot en met 69 jaar. De logaritmisch getransformeerde multipele lineaire regressie analyse bevestigde deze bevindingen (tabel 8.4).

Tabel 8.4 Multipele lineaire regressie-analyse, na logaritmische transformatie, voor de afhankelijke variabelen ziekteduur en periode van onderbreking der dagelijkse bezigheden bij deelnemers met een influenzaachtige ziekte (IAZ) $(n=281)$ en deelnemers met een influenza-achtige ziekte waarbij influenza serologisch werd bewezen (IAZ/SER) $(n=54)$

\section{Onafhan-}

kelijke variabelen Code

Afhankelijke variabelen

\begin{tabular}{|c|c|c|c|c|c|c|c|c|}
\hline & \multicolumn{4}{|c|}{ Ziekteduur } & \multicolumn{4}{|c|}{$\begin{array}{l}\text { Periode van onderbreking } \\
\text { dagelijkse bezigheden }\end{array}$} \\
\hline & \multicolumn{2}{|r|}{$\mathrm{IAZ}$} & \multicolumn{2}{|c|}{ IAZ/SER } & \multicolumn{2}{|c|}{ IAZ } & \multicolumn{2}{|c|}{ IAZ/SER } \\
\hline & coëff & p-waarde & coëff & -waarde & coëff & waarde & coëff $\mathrm{p}$ & waarde \\
\hline $\begin{array}{lr}\text { Vaccinatie- } & \text { ja }=1 \\
\text { status } & \text { nee }=0\end{array}$ & 0,03 & 0,46 & $-0,003$ & 0,98 & 0,02 & 0,74 & 0,02 & 0,88 \\
\hline Risicostatus $\begin{array}{r}\mathrm{ja}=1 \\
\text { nee }=0\end{array}$ & 0,04 & 0,39 & 0,12 & 0,34 & 0,002 & 0,97 & $-0,07$ & 0,63 \\
\hline Geslacht $\begin{array}{r}\operatorname{man}=1 \\
\text { vrouw }=0\end{array}$ & $-0,05$ & 0,26 & $-0,11$ & 0,30 & 0,03 & 0,61 & $-0,09$ & 0,44 \\
\hline Leeftijd & 0,001 & 0,81 & 0,01 & 0,25 & $-0,01$ & 0,04 & 0,006 & 0,67 \\
\hline Intercept & 0,65 & & $-0,22$ & & 1,10 & & 0,15 & \\
\hline
\end{tabular}

\section{BESCHOUWING}

Hoewel niet significant lijkt in dit onderzoek de ziekteduur voor deelnemers met een IAZ, waarbij de diagnose influenza serologisch werd bewezen, gemiddeld korter te zijn (5,3 dagen) dan voor de deelnemers met een IAZ (6,7 dagen). Ook bleek de periode van ziekteduur tengevolge van IAZ bij oudere mensen korter te zijn dan de verzuimduur zoals opgegeven wordt door het CBS.

In tegenstelling tot onze gegevens zijn die van het CBS verzameld bij werknemers. De diagnosecriteria voor de CBS-gegevens zijn niet eenduidig en de werkomstandigheden zijn anders. Het is zeker mogelijk dat de drempel voor het hervatten van de noodzakelijke bezigheden voor gepensioneerden anders is dan voor mensen die deelnemen aan het arbeidsproces. 
De diverse publicaties over dit onderwerp zijn moeilijk vergelijkbaar. Zo zijn er verschillen in samenstelling van de onderzoekspopulatie, de definitie van ziekteduur, de gebruikte diagnostische criteria en de wijze waarop geregistreerd werd. Baker en medewerkers (8) registreerden bij werknemers van een farmaceutisch bedrijf in 1981 een afwezigheid van gemiddeld 4,5 dagen bij patiënten met een influenza of influenza-achtige ziekte. In een Noorse studie van 5042 ziekte-episodes werd een kortere ziekteduur gevonden: 2 dagen bij vrouwen en 2,4 dagen bij mannen. Echter hierbij werd de ziekteduur korter dan 3 dagen niet geteld (6). In een onderzoek onder ziekenhuismedewerkers werd een gemiddelde ziekteduur gevonden van 6 dagen bij gevaccineerden en 8 dagen bij niet-gevaccineerden (statistisch niet significant verschillend) (9).

De grote spreiding in de ziekteduur en de periode van werkonderbreking in ons onderzoek wordt wellicht veroorzaakt doordat achter het verzamelbegrip influenza-achtige ziekten een grote variatie van ernstige en minder ernstige ziekten schuil kan gaan. Uit de kwartielwaarden kan men opmaken dat de meeste patiënten na 6 dagen (P75) hun normale bezigheden weer hervatten en niet langer dan 10 dagen (P75) ziek zijn. In eerdere studies werd gevonden dat gevaccineerde grieppatiënten nauwelijks korter ziek zijn dan niet gevaccineerde grieppatiënten $(8,9)$. Het betreft hier echter jongere werknemers. Het lijkt erop dat de deelnemers uit de oudere leeftijdscategorie met influenza-achtige ziektebeelden gemiddeld eerder hun normale bezigheden kunnen hervatten. Een vertekening van deze uitkomst kan zijn ontstaan doordat van de deelnemers $70 \%$ behoorde tot de $60-69$ jarigen en $30 \%$ tot de $\geq 70$ jarigen. De groep 60-69 jarigen zal waarschijnlijk meer actief werkzaam zijn dan die der $\geq 70$ jarigen. Bovendien zal de groep $\geq 70$ jarigen meer uit alleenstaanden bestaan en uit hoofde van dien eerder genoodzaakt zijn de dagelijkse bezigheden te hervatten.

Concluderend denken we te mogen stellen dat oudere mensen tengevolge van influenza niet langer ziek zijn dan 5 tot 6 dagen en dat influenzavaccinatie de ziekteduur niet zal beïnvloeden maar wel het optreden van influenza doet verminderen. . 


\section{LITERATUUR}

1 Lamberts H, Brouwer HJ, Mohrs J. Reason for encounter \& episode \& proces oriented standard output from Transitions project. Part I. Amsterdam: University of Amsterdam, 1991

2 Velden J van den, Bakker DH de, Claessens AAMC, Schellevis FG. Een nationale studie naar ziekten en verrichtingen in de huisartspraktijk. Basisrapport: Morbiditeit in de huisartspraktijk. Utrecht: NIVEL, 1991

3 Nederlands instituut voor onderzoek van de eerstelijnsgezondheidszorg (NIVEL). Continue morbiditeits registratie peilstations Nederland. 1988/89. Utrecht: Nivel, 1991.

4 Centraal Bureau voor de Statistiek, Ministerie van Welzijn, Volksgezondheid en Cultuur. Vademecum gezondheidsstatistiek Nederland 1992. Den Haag: CBS-publikaties, 1992/89

5 Tellnes G. Duration of sickness certification. Scand J Prim Health Care 1989; 7: 237-44

6 Tellnes G. Days lost by sickness certification. Scand J Prim Health Care 1989; 7: 245-51

7 Hammond GW, Cheang M. Absenteisme among hospital staff during an influenza epidemic: implications for immuno- prophylaxis. Can Med Assoc J 1984; 134: 449-52

8 Baker CC, Cameron AS. The effect of influenza immunization on absence. J Soc Occup Med 1985; 35: 134-36

9 Weingarte S, Staniloff H, Ault M, Miles P, Bamberger M, Meyer R. Do hospital employees benefit from the influenza vaccine? J Gen Int Med 1988; 3: 31-37

10 Keren G, Segev S, Morag A, Zakay-Rones Z, Barzilai A, Rubinstein E. Failure of influenza vaccination in the aged. J Med Virol 1988; 25: 85-89

11 Strassburg MA, Greenland S, Sorvillo FJ, Lieb LE, Habel LA. Influenza in the elderly: report of an outbreak and a revieuw of vaccine effectiveness reports. Vaccine 1986; $4: 38-44$

12 Gardner ID. The effect of aging on susceptibility to infection. Rev Infect Dis 1980; 25: 801-10

13 Gross PA, Quinnan GV, Weksler ME, Gaerlan PF, Denning CR. Immunization of elderly people with high doses of influenza vaccine. J Am Geriatr Soc 1988; 36: 209-12

14 Gezondheidsraad: Commissie vaccinatie tegen influenza. Vaccinatie tegen influenza: seizoen 1991-1992. Den Haag: Gezondheidsraad, 1991/15

15 Palache AM, Beyer WEP, Sprenger MJW, Masurel N, Jonge S de, Vardy A, et al. Antibody response after influenza immunization with various vaccine doses: a double blind, placebo controlled, multicentre, dose-response study in eldery nursing home residents and young volunteers. Vaccine 1993; 11: $3-9$

16 Masurel N, Ophof B, Jong P de. Antibody respons to immunization with influenza AVUSSR/77 (H1N1) virus in young individuals primed or unprimed for ANew Jersey/76 (H1N1) virus. J Hyg 1981; 87: 201-09

17 Classification Committee of Wonca. ICHPPC-2-defined. Inclusion criteria for the use of the rubrics of the International Classification of Health Problems in Primary Care. Oxford: Oxford University Press, 1983

18 Lamberts H, Wood M. International Classification of Primary Care. Oxford: Oxford University Press, 1983

$19 \mathrm{Pel}$ JZS. Proefonderzoek naar de frequentie en de etiologie van griepachtige ziekten in de winter 1963-1964. Huisarts Wet 1965; 8: 321-24

20 Pyhälä $R$, Kleemola $M$. The value of complement fixation and haemagglutination inhibition tests in the diagnosis of influenza A. Acta Virol 1976; 20: 66-69

21 Dixon WJ. BMDP statistical manual. California, Berkeley: University of California Press, 1981 


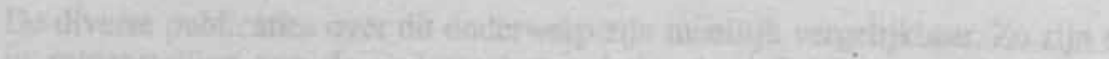

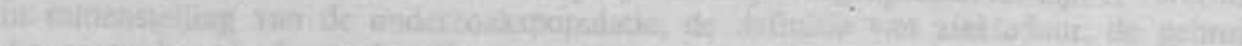

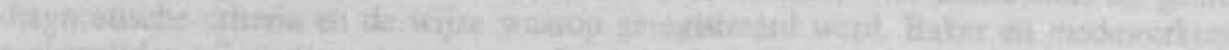

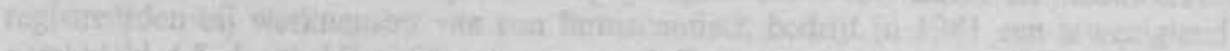

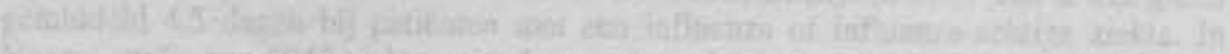

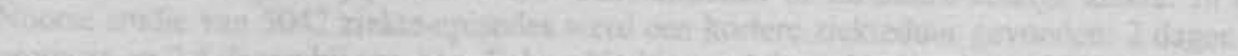

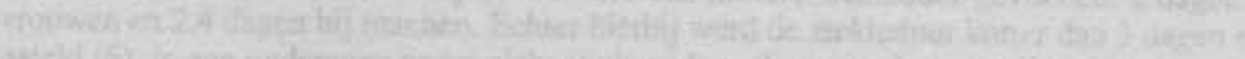

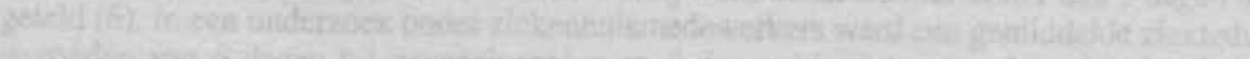

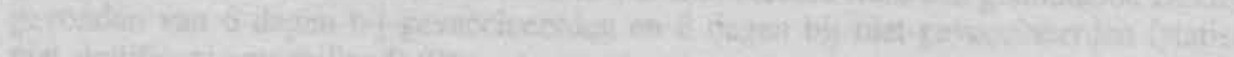

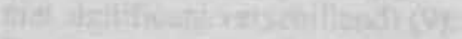

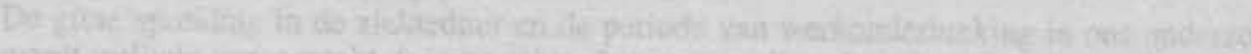

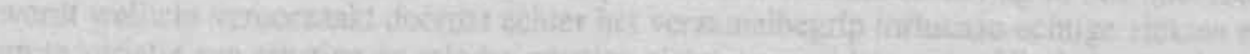

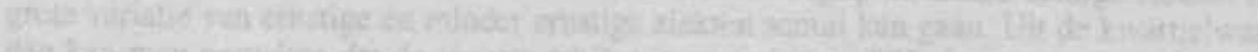

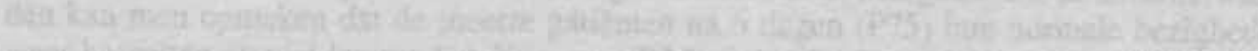

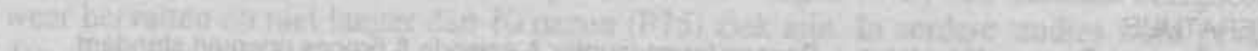

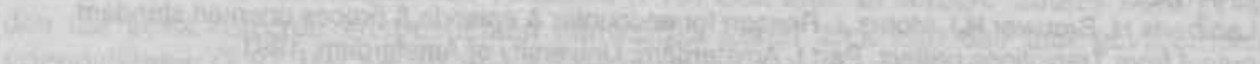

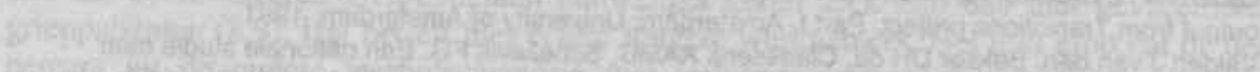

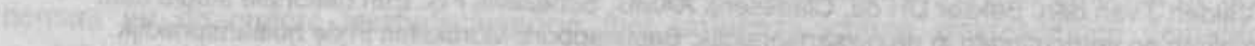

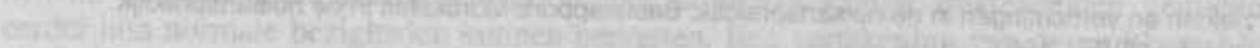

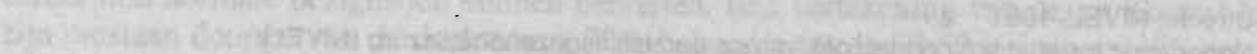

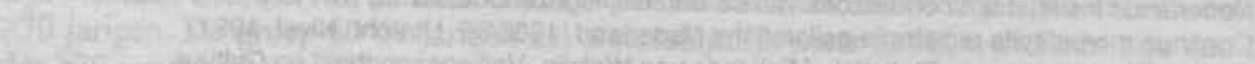

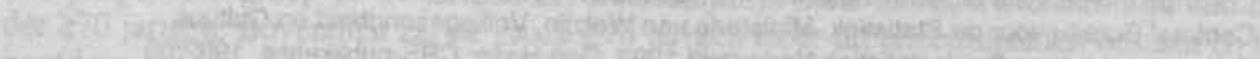

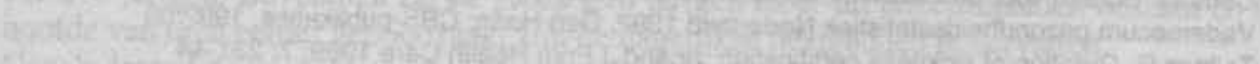

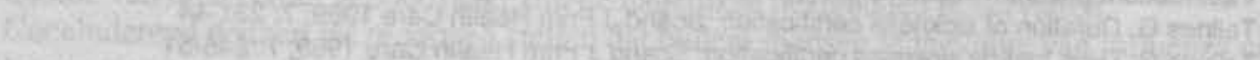

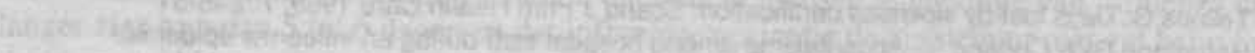

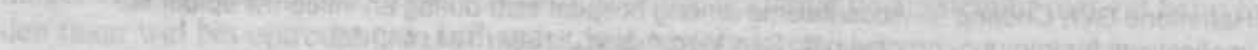

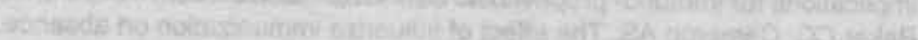

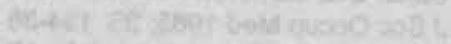

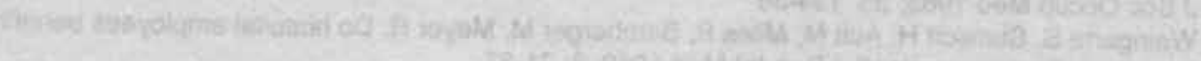

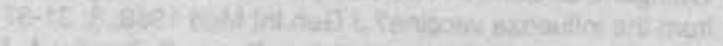

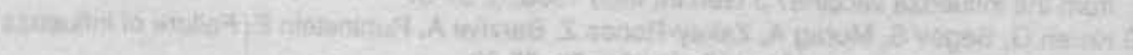

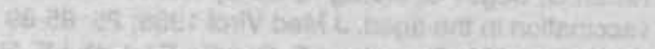

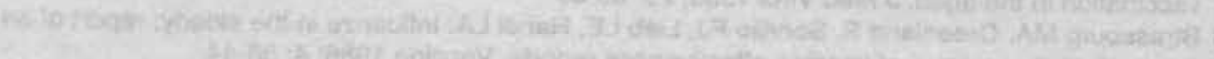

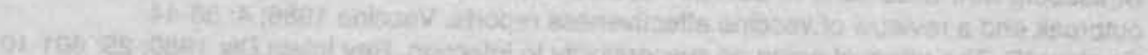

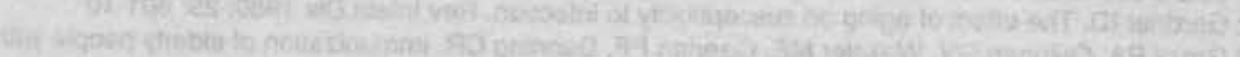

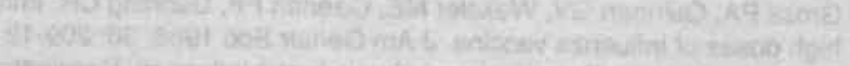

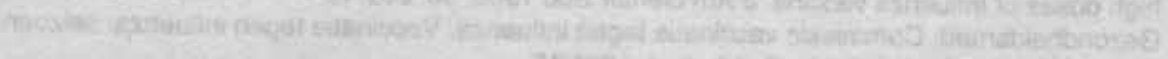

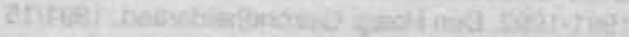

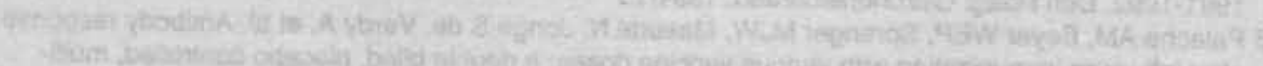

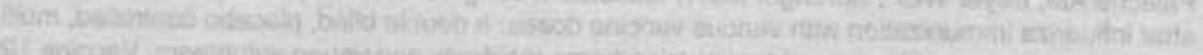

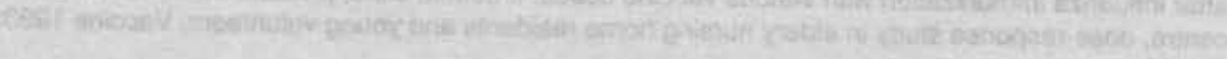

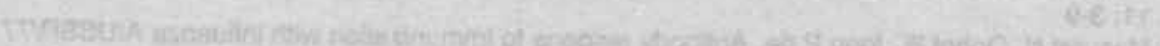

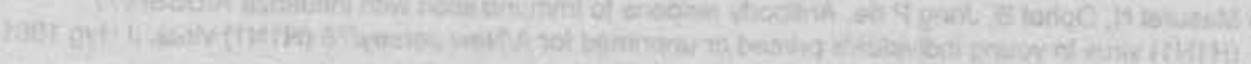

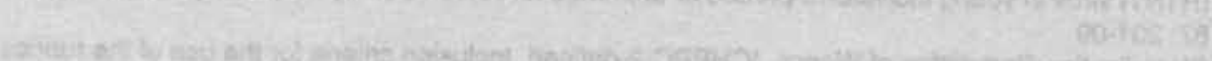

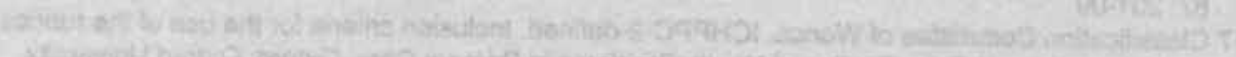

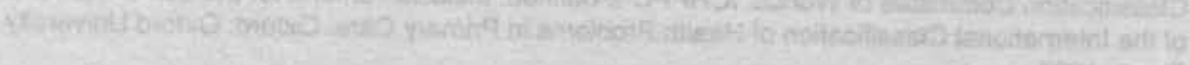

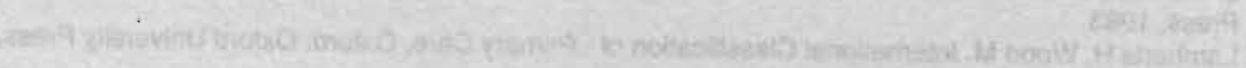
45:

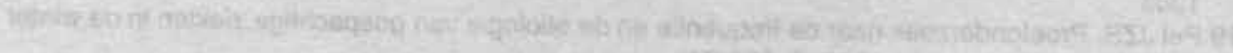

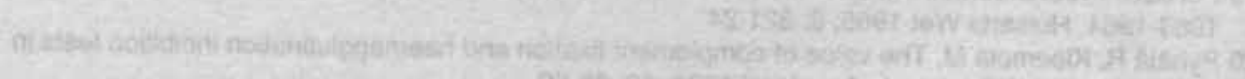

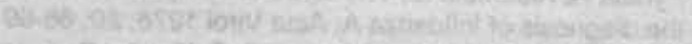

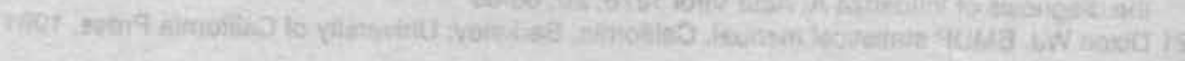




\section{HOOFDSTUK 9}

\section{BIJWERKINGEN VAN INFLUENZAVACCINATIE BIJ OUDEREN:}

een gerandomiseerde, dubbelblinde, placebo-gecontroleerde studie

Th.M.E. Govaert, G.J. Dinant, M.J.W. Sprenger. K. Aretz,

N. Masurel, J.A. Knottnerus,

Br Med J 1993; 307: 988-90 


\section{SAMENVATTING}

Doel. Bepalen van frequentie en aard van bijwerkingen ten gevolge van influenzavaccinatie bij ouderen.

Opzet. Gerandomiseerde, dubbelblinde, placebo-gecontroleerde studie.

Plaats. Vijftien huisartspraktijken in Zuid Nederland.

Methode. Bij 1838 personen in de leeftijd van 60 jaar en ouder werd dubbelblind gerandomiseerd influenzavaccin of placebo toegediend. Vier weken later werd hen verzocht een vragenlijst in te vullen waarin de meest voorkomende bijwerkingen ten gevolge van influenzavaccinatie vermeld stonden. Statistische analyse geschiedde door middel van de Chikwadraattoets voor onafhankelijke proporties en de Fisher exact test. Door middel van logistische regressie-analyse zijn de bijdragen van de onafhankelijke variabelen op de frequentie van de bijwerkingen in onderlinge samenhang bestudeerd.

Resultaten. Van de deelnemers retoumeerden 1806 personen de enquêtelijsten. In de vaccingroep ( $n=904)$ meldden $23,2 \%$ personen één of meer bijwerkingen, in de placebogroep $(n=902) 14,1 \%$. Er was een statistisch significant verschil in het voorkomen van locale bijwerkingen tussen vaccin- en placebogroep $(17,5 \%$ versus $7,3 \% ; p<0,01)$. Voor wat betreft systemische bijwerkingen bestond er geen statistisch significant verschil tussen vaccin- en placebogroep $(11,0 \%$ versus $9,4 \% ; \mathrm{p}=0,34)$. Alle gemelde bijwerkingen waren mild van aard. Naarmate de patiënten ouder waren, was er minder verschil in aantal bijwerkingen tussen vaccin- en placebogroep. Mannen meldden duidelijk minder bijwerkingen dan vrouwen.

Conclusie. Alleen locale bijwerkingen kwamen bij gevaccineerden vaker voor dan bij niet gevaccineerden. Alle bijwerkingen waren mild en van voorbijgaande aard.

Sleutelwoorden: influenzavaccinatie, bijwerkingen, ouderen, randomised controlled trial. 


\section{INLEIDING}

Ondanks uitgebreide voorlichting met betrekking tot influenza-vaccinatie van risicopatiënten blijft de vaccinatiegraad laag (1-6). Een van de redenen is dat patiënten angstig zijn voor bijwerkingen tengevolge van de "griepspuit" (7-9). Publicaties met betrekking tot het vóórkomen van bijwerkingen zijn niet eensluidend in hun conclusies (10-16). De studies vertonen belangrijke methodologische verschillen $(10-12,14,15)$. Slechts drie ervan waren gerandomiseerd $(13,16,17)$.

Oudere mensen lopen een verhoogd risico tijdens epidemieën voor wat betreft mortaliteit en morbiditeit tengevolge van influenza (18-21). Er wordt reeds gepleit om alle mensen ouder dan 60 jaar te vaccineren (22).

Wij bestudeerden in een gerandomiseerde, dubbelblinde, placebo-gecontroleerde studie bij oudere mensen de volgende vragen:

* Welke bijwerkingen treden op ten gevolge van influenzavaccinatie en in welke frequentie?

* Wat is hierbij de invloed van risicostatus, leeftijd, geslacht, en het al of niet eerder gevaccineerd zijn?

\section{METHODE}

\section{Patiënten}

Aan het onderzoek, uitgevoerd in het seizoen 1991-'92, namen 34 huisartsen uit 15 huisartspraktijken deel. De totale populatie van deze praktijken bedroeg 68.988 patiënten. Uitgesloten van het onderzoek werden patiënten die door de huisarts geacht werden te behoren tot een risicogroep volgens het advies van de Gezondheidsraad (23), alsmede patiënten die verbleven in verzorgings- en verpleegtehuizen. Van de resterende groep werden alle personen van 60 jaar en ouder uitgenodigd voor deelname aan het onderzoek. Van de 9907 uitgenodigde personen stemden $1838(18,6 \%)$ in met deelname aan het onderzoek; 869 mannen $(47,3 \%)$ en 969 vrouwen $(52,7 \%)$. De gemiddelde leeftijd was 67 jaar (standaard deviatie 6; mediaan 66) en de range liep van 60 tot 91 jaar. In totaal 185 patiënten gaf aan in 1989 en 1990 te zijn gevaccineerd tegen influenza. Volgens opgave van de deelnemers bleken 490 patiënten alsnog cardiologische, pulmonale of stofwisselingsproblematiek te hebben. Deze was naar het oordeel van de eigen huisarts echter niet van dien aard dat vaccinatie was aangewezen. Bij de deelnemende huisartsen bleek er een verschillende interpretatie te zijn van het begrip risicopatiënt. Om de invloed van de risicostatus op de mate en aard van bijwerkingen te beoordelen, werden deze patiënten ingedeeld in vier categorieën: hartaandoeningen, longaandoeningen, diabetes mellitus en geen of andere aandoeningen (bijvoorbeeld status na cerebro-vasculair accident).

\section{Procedure}

Het gezuiverd split-vaccin werd geproduceerd door Evans Medical Ltd, Langhurst, Horsham, England. Dit vaccin was, evenals de andere in Nederland verkrijgbare griepvaccins, samengesteld volgens de richtlijnen van de World Health Organisation en de Gezondheidsraad. Elke dosis bevatte: A/Singapore/6/86 (H1N1), A/Beijing/353/89 (H3N2), $\mathrm{B} /$ Panama/45/90 en B/Beijing/1/87, allen equivalent met 15 microgrann hemagglutinine. Als placebo werd fysiologisch zout gebruikt. Tussen 1 en 15 november 1991 ontvingen de deelnemers een injectie met vaccin of placebo in de linker of rechter musculus deltoïdeus volgens een gestratificeerd randomisatieschema. Er werden vier strata geformeerd, volgens de boven genoemde categorieën van aandoeningen. Vier weken later ontvingen de deelnemers een voorgedrukt enquêteformulier waarin hen werd gevraagd naar bijwerkingen ontstaan binnen 48 uur na vaccinatie. De vragenlijsten werden geanalyseerd zonder voorkennis van de vaccinatiestatus. 


\section{Statistische analyse}

Statistische analyse vond plaats door middel van de Chi-kwadraattoets voor onafhankelijke proporties en door middel van de Fisher exact test indien het aantal verwachte waarnemingen in tenminste één der cellen 5 of minder bedroeg.

Door middel van multipele logistische regressie analyse zijn de bijdragen van de onafhankelijke variabelen vaccinatiestatus (vaccin-placebo), risicostatus, leeftijd, geslacht, en het al of niet eerder, met name de laatste twee jaren, gevaccineerd zijn op de frequentie van de bijwerkingen in onderlinge samenhang bestudeerd. Afhankelijke variabelen waren achtereenvolgens: de kans op bijwerkingen in het algemeen, de kans op systemische bijwerkingen en de kans op locale bijwerkingen. Op grond van de gevonden regressiefuncties werden telkens odds ratio's met $95 \%$ betrouwbaarheidsintervallen berekend, voor zowel de volledige modellen (met alle factoren) als de gereduceerde modellen (alleen met significant bijdragende factoren). De analyses werden verricht op een VAX-mainframe computer, met behulp van het programma BMDP-LR.

\section{Goedkeuring medisch ethische commissie}

Het protocol werd goedgekeurd door de medisch-ethische commissie van de Rijksuniversiteit Limburg en het Academisch Ziekenhuis Maastricht. Door alle deelnemers werd een "informed consent" ondertekend.

\section{RESULTATEN}

De samenstelling van de onderzoekpopulatie wordt weergegeven in tabel 9.1. Het aantal gevaccineerden en niet gevaccineerden was nagenoeg gelijk verdeeld in de subgroepen risicopatiënten, mannen, vrouwen, leeftijd en voorafgaande vaccinatiestatus. Van de 1838 deelnemers retourneerden er 1806 de enquêtelijsten. De 32 deelnemers, die de formulieren niet retourneerden waren gelijk verdeeld over vaccin- en placebogroep. Een deelnemer stierf aan een hartinfarct 4 dagen na vaccinatie (met placebo). Hij veronderstelde dat de pijn in zijn linker arm werd veroorzaakt door de "spuit".

Van de deelnemers meldden $23,2 \%$ uit de vaccingroep ( $n=904)$ bijwerkingen, zowel locale en/of systemische, tegen $14,1 \%$ uit de placebogroep $(n=902)$ (tabel 9.2). Locale bijwerkingen werden statistisch significant vaker gemeld door gevaccineerden in vergelijking met niet gevaccineerden: $17,5 \%$ versus $7,3 \%(p<0,01)$. Pijn bij aanraking van de injectieplaats was de meest gemelde locale bijwerking. Er bestond statistisch geen significant verschil tussen vaccin- en placebogroep bij systemische bijwerkingen. Van de systemische bijwerkingen werd malaise het meest gemeld. In de vaccin- en in de placebogroep werden door 33 respectievelijk 31 patiënten ook nog de volgende klachten genoemd: myalgieën, misselijkheid, rillingen, duizeligheid, moeheid, keelpijn, allergie, kortademigheid, jeuk over het hele lichaam, ontregeling diabetes mellitus, rhinitis en duizeligheid met hoofdpijn. Deze klachten waren alle niet emstig van aard en waren in gelijke mate verdeeld over vaccin- en placebogroep.

Vergelijkbare bevindingen werden gevonden bij potentiële risicopatiënten (tabel 9.3). Bijwerkingen werd door $24,8 \%$ van de vaccingroep $(n=246)$ gemeld. Tussen de vaccin- en placebogroep bestond statistisch geen significant verschil wat betreft het aantal patiënten dat systemische bijwerkingen meldde, maar wel wat betreft diegenen die locale bijwerkingen meldden. In de groep potentiële risicopatiënten werden locale bijwerkingen iets frequenter geregistreerd $(21,1 \%)$ dan in de groep patiënten zonder risico $(17,5 \%)$, doch dit verschil was niet significant.

Ook de subgroepen met hart- en longaandoeningen toonden eenzelfde patroon: bijwerkingen werden door $18 \%$ van de hartpatiënten en door $23,9 \%$ van de longpatiënten gemeld. Er was geen statistisch significant verschil tussen vaccin- en placebogroep in de frequentie van 
Tabel 9.1 Samenstelling onderzoekpopulatie $(\mathrm{n}=1838)$

\begin{tabular}{|c|c|c|c|c|c|}
\hline \multirow{2}{*}{\multicolumn{2}{|c|}{ Subgroep }} & \multicolumn{2}{|c|}{ Vaccin $(n=927)$} & \multicolumn{2}{|c|}{ Placebo $(n=911)$} \\
\hline & & $\mathrm{n}$ & & $\mathrm{n}$ & \\
\hline \multicolumn{6}{|c|}{$\overline{\text { Potentiële risicostatus }}$} \\
\hline & Hartaandoeningen & 125 & 13,5 & 124 & 13,6 \\
\hline & Longaandoeningen & 105 & 11,3 & 95 & 10,4 \\
\hline & Diabetes mellitus & 21 & 2,3 & 20 & 2,2 \\
\hline & Overigen/gezonden & 676 & 72,9 & 672 & 73,8 \\
\hline & Totaal & 927 & 100 & 911 & 100 \\
\hline \multicolumn{6}{|l|}{ Geslacht } \\
\hline & Man & 420 & 45,3 & & 49,3 \\
\hline & Vrouw & 507 & 54,7 & 462 & 50,7 \\
\hline & Totaal & 927 & 100 & 911 & 100 \\
\hline \multirow{2}{*}{\multicolumn{6}{|c|}{ Leeftijd }} \\
\hline & $60-64$ & 368 & 39,7 & 396 & 43,5 \\
\hline & $65-69$ & 281 & 30,3 & 249 & 27,3 \\
\hline & $70-74$ & 176 & 19,0 & 177 & 19,4 \\
\hline & & 66 & 7,1 & 61 & 6,7 \\
\hline & $80-84$ & 29 & 3,1 & 19 & 2,1 \\
\hline & $85-91$ & 7 & 0,8 & 9 & 1,0 \\
\hline & Totaal & 927 & 100 & 911 & 100 \\
\hline \multicolumn{6}{|c|}{ Eerder gevaccineerd } \\
\hline & & 118 & $\begin{array}{l}12,7 \\
873\end{array}$ & 120 & 13,2 \\
\hline & Thtagl & 927 & 100 & 911 & 10 \\
\hline
\end{tabular}

systemische bijwerkingen maar wel in de frequentie van locale bijwerkingen. De p-waarde voor de vergelijking vaccin versus placebo voor locale bijwerkingen was voor hartpatiënten 0,01 , voor longpatiënten 0,04 . Door $25,9 \%$ van de patiënten met een diabetes mellitus $(n=59)$ werden bijwerkingen gemeld. Hier bestond geen statistisch significant verschil tussen vaccin- en placebogroep, noch wat betreft systemische noch wat betreft locale bijwerkingen.

Onder de groep deelnemers die in de voorafgaande twee jaren reeds gevaccineerd waren, werd geen significant verschil gevonden in de frequentie van bijwerkingen tussen gevaccineerden $(n=92)$ en niet gevaccineerden ( $n=91) ; 20,7 \%$ versus $20,9 \%(p=0,97)$. Ook was dit niet het geval voor locale bijwerkingen $(\mathrm{p}=0,32)$.

Met het vorderen der leeftijd werd minder verschil gevonden in het aantal bijwerkingen tussen vaccin- en placebogroep (tabel 9.4).

Zowel in de vaccin- als in de placebogroep meldden mannen duidelijk minder bijwerkingen dan vrouwen (tabel 9.5). Er is wederom een statistisch significant verschil tussen het vóorkomen van het totale aantal, respectievelijk het aanta! locale bijwerkingen naar vaccinatiestatus zowel bij mannen als bij vrouwen.

Alle bijwerkingen waren mild en van voorbijgaande aard.

De resultaten van de multipele logistische regressie-analyse bevestigden het reeds geschetste beeld (tabel 9.6). De invioed van vaccinatie betrof uitsluitend locale bijwerkingen 
Tabel 9.2 Aantal en percentage patiënten dat locale en/of systemische bijwerkingen meldde, naar vaccinatiestatus.

\begin{tabular}{|c|c|c|c|c|c|}
\hline \multirow[t]{2}{*}{ Bijwerkingen } & \multicolumn{2}{|c|}{$\begin{array}{c}\text { Vaccin } \\
(\mathrm{n}=904)\end{array}$} & \multicolumn{2}{|c|}{$\begin{array}{l}\text { Placebo } \\
(\mathrm{n}=902)\end{array}$} & \multirow[t]{2}{*}{ p-waarde } \\
\hline & $\mathrm{n}$ & $\%$ & $\mathrm{n}$ & $\%$ & \\
\hline$\overline{\text { Locale }}$ & 158 & 17,5 & 66 & 7,3 & 0,00 \\
\hline zwelling & 66 & 7,3 & 8 & 0,9 & 0,00 \\
\hline jeuk & 41 & 4,5 & 13 & 1,4 & 0,00 \\
\hline warm gevoel & 43 & 4,8 & 14 & 1,6 & 0,00 \\
\hline pijn bij aanraking & 94 & 10,4 & 29 & 3,2 & 0,00 \\
\hline steeds pijn & 17 & 1,9 & 8 & 0.9 & 0,07 \\
\hline ongemak & 23 & 2,5 & 19 & 2,1 & 0,53 \\
\hline Systemische & 99 & 11,0 & 85 & 9,4 & 0,34 \\
\hline koorts & 12 & 1,3 & 6 & 0,7 & 0,15 \\
\hline hoofdpijn & 44 & 4,9 & 35 & 3,9 & 0,30 \\
\hline malaise & 58 & 6,4 & 50 & 5,5 & 0,45 \\
\hline andere klachten & 33 & 3,7 & 31 & 3,4 & 0,82 \\
\hline $\begin{array}{l}\text { Locale en/of } \\
\text { systemische }\end{array}$ & 210 & 23,2 & 127 & 14,1 & 0,00 \\
\hline
\end{tabular}

32 deelnemers werden uitgesloten wegens onvolledige gegevens.

Tabel 9.3 Aantal en percentage potentiële risicopatiënten dat locale en/of systemische bijwerkingen meldde, naar vaccinatiestatus.

\begin{tabular}{|c|c|c|c|c|c|}
\hline \multirow[t]{2}{*}{ Bijwerkingen } & \multicolumn{2}{|c|}{$\begin{array}{l}\text { Vaccin } \\
(n=246)\end{array}$} & \multicolumn{2}{|c|}{$\begin{array}{l}\text { Placebo } \\
(n=234)\end{array}$} & \multirow[t]{2}{*}{ p-waarde } \\
\hline & n & $\%$ & n & $\%$ & \\
\hline Locale: & 52 & 21,1 & 20 & 8,5 & 0,00 \\
\hline zwelling & 25 & 10,2 & 2 & 0,9 & 0,00 \\
\hline jeuk & 18 & 7,3 & 6 & 2,6 & 0,02 \\
\hline warm gevoel & 17 & 6,9 & 4 & 1,7 & 0,01 \\
\hline pijn bij aanraking & 30 & 12,2 & 10 & 4,3 & 0,00 \\
\hline steeds pijn & 6 & 2,4 & 3 & 1,3 & 0,50 \\
\hline ongemak & 4 & 1,6 & 4 & 1,7 & 1,00 \\
\hline Systemische & 27 & 11,0 & 28 & 12,0 & 0,73 \\
\hline koorts & 2 & 0,8 & 2 & 0,9 & 1,00 \\
\hline hoofdpijn & 13 & 5,3 & 15 & 6,4 & 0,60 \\
\hline malaise & 14 & 5,7 & 17 & 7,3 & 0,50 \\
\hline andere klachten & 8 & 3,3 & 11 & 4,7 & 0,56 \\
\hline Locale en/of & & & & & \\
\hline systemische & 61 & 24,8 & 38 & 16,2 & 0,02 \\
\hline
\end{tabular}

10 deelnemers werden uitgesloten wegens onvolledige gegevens 
Tabel 9.4 Aantal en percentage patiënten dat bijwerkingen meldde, verdeeld naar leeftijdsgroep en vaccinatiestatus.

Leeftijd Vaccinatie-

Bijwerkingen status

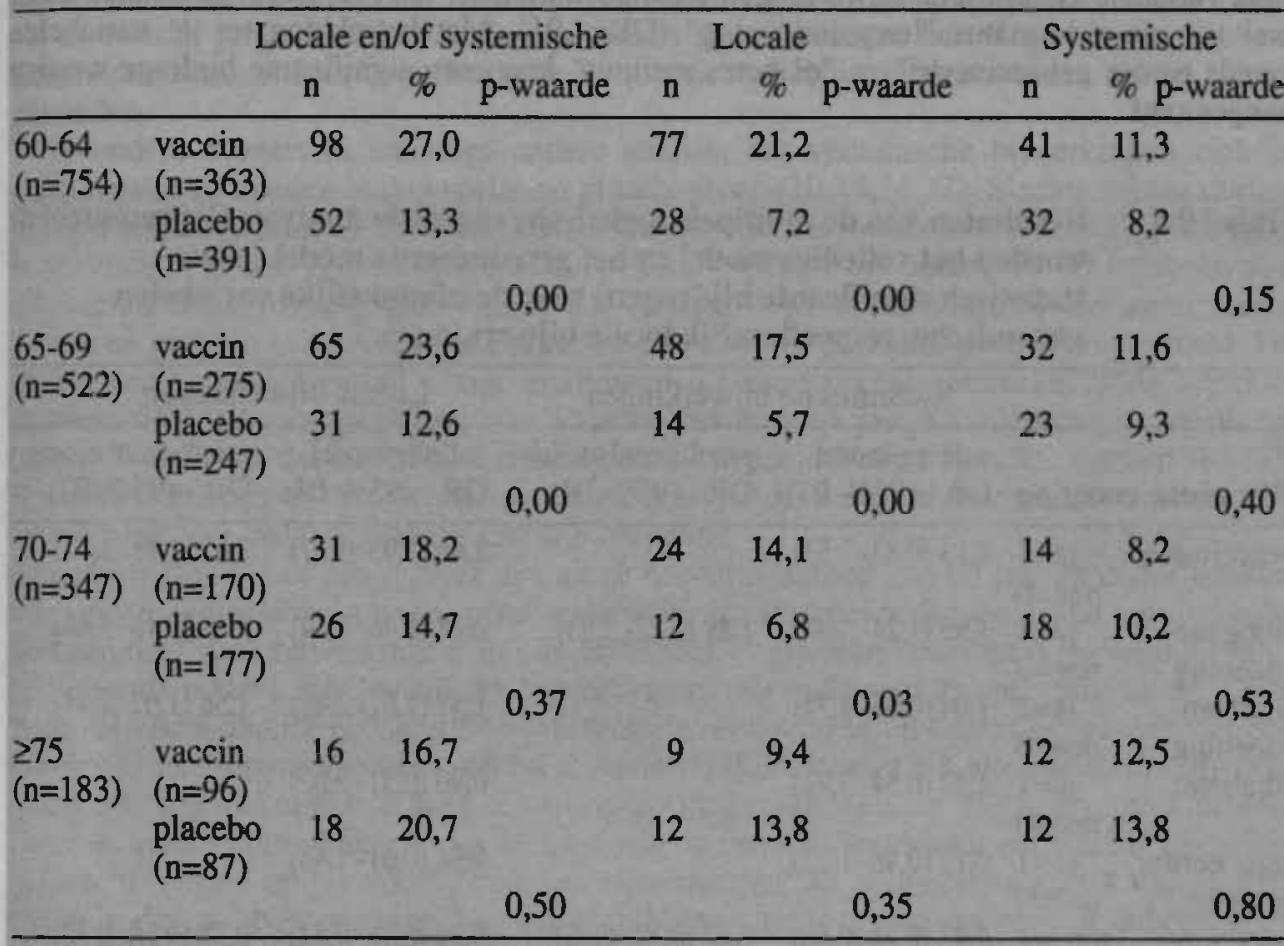

32 deelnemers werden uitgesloten wegens onvolledige gegevens

Tabel 9.5 Aantal en percentage mannen en vrouwen verdeeld naar vaccinatiestatus dat bijwwerkingen meldde.

\begin{tabular}{|c|c|c|c|c|c|c|}
\hline \multirow[t]{3}{*}{ Bijwerkingen } & \multicolumn{4}{|c|}{ Vaccinatiestatus } & & \\
\hline & \multicolumn{2}{|c|}{ Vaccin } & \multicolumn{2}{|c|}{ Placebo } & \multicolumn{2}{|c|}{$\begin{array}{c}\text { p-waarde } \\
\text { vaccin versus placebo }\end{array}$} \\
\hline & $\underset{(\mathrm{n}=411)}{\operatorname{Man}}$ & $\begin{array}{l}\text { Vrouw } \\
(\mathrm{n}=493)\end{array}$ & $\underset{(\mathrm{n}=444)}{\operatorname{Man}}$ & $\begin{array}{l}\text { Vrouw } \\
(n=4.58)\end{array}$ & $\begin{array}{c}\text { vaccin versus } \\
\text { Man }\end{array}$ & $\begin{array}{l}\text { placebo } \\
\text { Vrouw }\end{array}$ \\
\hline & $\begin{array}{c}\mathrm{n} \\
(\%)\end{array}$ & $\begin{array}{c}\mathrm{n} \\
(\%)\end{array}$ & $\begin{array}{c}\mathrm{n} \\
(\%)\end{array}$ & $\underset{(\%)}{n}$ & & \\
\hline Locale & $\begin{array}{l}41 \\
(10,1)\end{array}$ & $\begin{array}{l}117 \\
(23,7)\end{array}$ & $\begin{array}{l}25 \\
(5,6)\end{array}$ & $\begin{array}{l}41 \\
(9,0)\end{array}$ & 0,02 & 0,00 \\
\hline Systemische & $\begin{array}{l}32 \\
(7,8)\end{array}$ & $\begin{array}{c}67 \\
(13,6)\end{array}$ & $\begin{array}{l}28 \\
(6,3)\end{array}$ & $\begin{array}{c}57 \\
(12,4)\end{array}$ & 0,40 & 0,60 \\
\hline $\begin{array}{l}\text { Locale en/of } \\
\text { systemische }\end{array}$ & $\begin{array}{l}62 \\
(15,1)\end{array}$ & $\begin{array}{l}148 \\
(30,0)\end{array}$ & $\begin{array}{l}42 \\
(9,5)\end{array}$ & $\begin{array}{c}85 \\
(18,6)\end{array}$ & 0,01 & 0,00 \\
\hline
\end{tabular}


$(\mathrm{OR}=2,62)$, waarbij bekendheid met long- en in minder mate hartaandoeningen nog extra invloed had $(\mathrm{OR}=2,23$, respectievelijk 1,56). Locale bijwerkingen kwamen, ook na correctie van de andere factoren, duidelijk minder vaak voor bij mannen $(\mathrm{OR}=0,38)$. Hogere leeftijd had over het geheel genomen een licht negatieve invloed. Ten aanzien van de afhankelijke variabele systemische bijwerkingen werd geen invloed van het vaccin gevonden, maar wel van de risicostatus "longaandoening" $(\mathrm{OR}=1,95)$. Met betrekking tot de variabelen "reeds eerder gevaccineerd" en "diabetes mellitus" kon geen significante bijdrage worden aangetoond.

\begin{tabular}{|c|c|c|c|c|c|}
\hline \multirow[t]{2}{*}{ Tabel 9.6} & \multicolumn{5}{|c|}{$\begin{array}{l}\text { Resultaten van de multipele logistische regressie-analyse. Gepresenteerdl } \\
\text { worden het volledige model en het gereduceerde model (alleen } \\
\text { statistisch significante bijdragen) voor de afhankelijke variabelen } \\
\text { systemische, respectievelijk locale bijwerkingen. }\end{array}$} \\
\hline & & \multicolumn{2}{|c|}{ Systemische bijwerkingen } & \multicolumn{2}{|c|}{ Locale bijwerkingen } \\
\hline \multicolumn{2}{|c|}{ Variabele codering } & $\begin{array}{l}\text { volledig model } \\
\text { OR }(95 \% \mathrm{BI})^{*}\end{array}$ & $\begin{array}{l}\text { gereduceerd model } \\
\text { OR }(95 \% \text { BI) }\end{array}$ & $\begin{array}{l}\text { volledig model } \\
\text { OR }(95 \% \text { BD) }\end{array}$ & $\begin{array}{l}\text { gereduccerd model } \\
\text { OR. (95\% BI) }\end{array}$ \\
\hline vaccinatie & $\begin{array}{r}\mathrm{ja}=1 \\
\text { nee }=0\end{array}$ & $1,13(0,83-1,53)$ & & $2,62(1,93-3,57)$ & $2,62(1,93-3,57)$ \\
\hline $\begin{array}{l}\text { longaan- } \\
\text { doening }\end{array}$ & $\begin{array}{r}\mathrm{ja}=1 \\
\mathrm{nee}=0\end{array}$ & $1,95(1,24-3,07)$ & $1,89(1,22-2,93)$ & $2,24(1,46-3,44)$ & $2,23(1,46 \cdot 3,40)$ \\
\hline $\begin{array}{l}\text { hartaan- } \\
\text { doening }\end{array}$ & $\begin{array}{r}\mathrm{ja}=1 \\
\mathrm{nee}=0\end{array}$ & $1,04(0,63-1,71)$ & & $1,57(1,02-2,42)$ & $1,56(1,02-2,41)$ \\
\hline diabetes & $\begin{array}{r}j a=1 \\
n e e=0\end{array}$ & $1,42(0,54-3,71)$ & & $0,90(0,31-2,62)$ & \\
\hline $\begin{array}{l}\text { niet eerder } \\
\text { ingeënt }\end{array}$ & $\begin{array}{r}\text { ja }=1 \\
\text { nee }=0\end{array}$ & $0,75(0,46-1,22)$ & & $0,94(0,61 \cdot 1,45)$ & \\
\hline geslacht & $\begin{array}{r}\operatorname{man}=1 \\
\text { vrouw }=0\end{array}$ & $0,47(0,34-0,66)$ & $0,47(0,34-0,65)$ & $0,38(0,28-0,52)$ & $0,38(0,28-0,52)$ \\
\hline leeftijd & per jaar & $1,01(0,98-1,04)$ & & $0,97(0,94-0,99)$ & $0,97(0,94-0,99)$ \\
\hline $\begin{array}{l}\text { Constante } \\
\text { antilogarith }\end{array}$ & $\begin{array}{l}\text { (natuurlij } \\
\text { hme) }\end{array}$ & $0,06(0,01 \cdot 0,39)$ & $0,141(0,116-0,172)$ & $0,94(0,15-5,90)$ & $0,96(0,15-5,97)$ \\
\hline
\end{tabular}

\section{BESCHOUWING}

Bijwerkingen tengevolge van influenzavaccinatie werden in dit onderzoek in de vaccin- en in de placebogroep door $23,2 \%$, respectievelijk: $14,1 \%$ der deelnemers gemeld. Locale bijwerkingen kwamen statistisch significant vaker voor in de vaccingroep. Bij eerder gevaccineerden was er geen statistisch significant verschil in aantal bijwerkingen tussen vaccinen placebogroep. Bij oudere mensen werd het verschil in aantal bijwerkingen tussen vaccinen placebogroep minder duidelijk. Vrouwen meldden opvallend meer bijwerkingen dan mannen $(30 \%$ versus $15 \%)$. Bijwerkingen waren alle van voorbijgaande aard en ernstige: bijwerkingen werden niet gerapporteerd.

In diverse publicaties wordt gemeld dat bijwerkingen tengvolge van influenzavaccinatie in slechts geringe mate voorkomen, locale tot. $20 \%$, systemische tot $5 \%(3,10,13,14,-16,23)$. 
Daarentegen wordt in een Canadees onderzoek melding gemaakt van een bijwerkingspercentage van $87 \%$ locale en $49 \%$ systemische (15). In deze studie werd echter een trivalent "whole-virion" vaccin gebruikt. Bovendien was dit een observationeel, niet gerandomiseerd, noch geblindeerd onderzoek onder ziekenhuispersoneel $(n=228)$. Behalve het behoren tot de medische professie, waardoor relatief snel een overrapportage kan plaatsvinden, zal de relatief jonge leeftijd van de deelnemers deze resultaten beïnvloed kunnen hebben. Eensluidende conclusies betreffende de frequentie van bijwerkingen worden al met al niet gevonden.

Wij vonden, evenals in sommige andere studies, dat systemische bijwerkingen zich in gelijke mate voordeden in de vaccin- en placebogroep $(10-14,16,17)$. Slechts enkele studies kunnen wat de methode betreft vergeleken worden met ons onderzoek $(13,16,17)$. Margolis et al. vonden in een gerandomiseerd, dubbelblind "crossover" onderzoek bij personen van 65 jaar en ouder $(n=336)$ geen significant verschil in aantal en soort bijwerkingen tussen vaccin en placebo (13). Alleen een pijnlijke arm werd in de vaccingroep vaker gemeld. De onderzoekpopulatie bestond echter uitsluitend uit oude oorlogsveteranen, bijna allemaal mannen. De onderzoekpopulatie van Palache bestond uit jonge studenten en verpleeghuispatiënten en is daarom geen weerspiegeling van een doorsnee bevolkingsgroep $(16,17)$. Bovendien werden de verpleeghuispatiënten geënquêteerd door onderzoekers waardoor een zekere mate van onderrapportage kan zijn ontstaan.

Ons onderzoek betrof een relatief niet zieke bevolkingsgroep van 60 jaar en ouder waarin, voor zover wij konden nagaan, geen selectie heeft plaatsgevonden op grond van bekende gevoeligheid voor bijwerkingen. In ons onderzoek is gekozen voor een schriftelijke evaluatie door de patiënt van de aard der bijwerkingen, vier weken na de vaccinatiedatum. Deze keuze is voornamelijk gebaseerd op practische overwegingen en brengt het gevaar van een minder exacte rapportage met zich mee. Anderzijds dreigt met het alternatief van bijvoorbeeld een dagboekmethode juist een overrapportage van wellicht niet relevante klachten. Het niet tevoren introduceren van de tekst van de enquête voorkwam dat patiënten a priori gefixeerd raakten op het vóórkomen van bijwerkingen; zij herinnerden zich 4 weken later alleen de "echte" bijwerkingen. Van een recall-bias is geen sprake vanwege de dubbelblinde opzet; het gevonden verschil kan alleen maar met de verschillende inhoud van het ingespoten materiaal te maken hebben.

Influenzavaccin bevat in tegenstelling tot fysiologisch zout conserveringsstoffen; in dit geval thiomersal $0,1 \mathrm{mg} / \mathrm{ml}$. Deze, tesamen met de nog minimaal aanwezige eiwitten, zijn vermoedelijk verantwoordelijk voor het frequenter voorkomen van locale reacties in de vaccingroep $(10,11)$.

Opvallend is dat naarmate men ouder wordt de verschillen tussen vaccin- en placebogroep minder duidelijk worden. Hierbij moeten we ons realiseren dat in de oudere leeftijdsgroepen de aantallen kleiner zijn. In eerdere studies werd gevonden dat systemische reacties tengevolge van influenzavaccinatie bij jongeren en vooral kinderen vaker voorkomen. Dit zou komen doordat jonge mensen nog niet vaak met influenza in aanraking zijn geweest waardoor bij hen te weinig antilichamen aanwezig zijn tegen de in het vaccin aanwezige influenzastammen $(13,15,24,25)$.

Bij eerder gevaccineerden bestond geen statistisch significant verschil tussen het aantal bijwerkingen in vaccin- en placebogroep. Mogelijk hadden deze deelnemers enige afweer ten gevolge van vorige vaccinaties waardoor het antigene effect van de vaccinatie minder tot uiting kwam $(24,25)$.

Het geslacht lijkt geen modificerende variabele te zijn wat betreft de relatie bijwerkingen en vaccinatiestatus. Het geslacht levert wel een onafhankelijke bijdrage; vrouwen meldden duidelijk vaker bijwerkingen dan mannen. Er zijn ook enkele eerdere studies waarin gesuggereerd wordt dat bijwerkingen bij vrouwen vaker voorkomen $(12,26,27)$. Een verklaring waarom vrouwen vaker bijwerkingen melden ontberen wij. Het zou kunnen zijn dat de pijndrempel bij vrouwen lager ligt dan bij mannen; dat de subjectieve beleving van de vrouw 
anders is dan bij de man; of dat de vrouw alerter is dan de man en dus beter registreert. Deze bevinding leidt in ieder geval tot de conclusie dat bij studies naar bijwerkingen een. onderscheid naar geslacht moet worden gehanteerd.

Wij achten het aannemelijk dat de bevindingen ten aanzien van aard en frequentie van bijwerkingen bij risicopatiënten uit deze onderzoekpopulatie ook van toepassing zijn voor de reeds als zodanig te boek staande risicopatiënten. Het feit dat een deelnemer stierf omdat hij veronderstelde dat de pijn in zijn linker arm het gevolg was van een bijwerking van vaccinatie in plaats van angina pectoris brengt ons tot de suggestie influenzavaccinaties, met name bij ouderen, niet in de linker musculus deltoïdeus te geven. Het milde karakter van bijwerkingen dient geen reden te zijn influenzavaccinatie te ontraden. 


\section{LITERATUUR}

1 Veen WA van. Influenzavaccinatie: hoe effectief is het beleid? Huisarts Wet 1990; 33: 415-16

2 Hofstra ML, Braak EM ter, Werf GTh van der, Smit RJA. Een geautomatiseerd zoek- en oproepsysteem voor vaccinatie tegen influenza. Huisarts Wet 1990; 33: 429-32

3 Centres for disease control influenza vaccination coverage levels in selected sites. United States, 1989. MMWR 1990; 39: (10): 111-13

4 Helliwel BE, Drummond MF. The costs and benefits of preventing influenza in Ontario's elderly. Can J Public Health 1988; $79:$ 175-79

5 Govaert ThME, Dinant GJ, Knottnerus JA. Vaccinatie tegen influenza in een huisartspraktijk. Opkomst en vaccinatiegraad van risicopatiënten. Huisarts Wet 1991; 34: 478-81

6 Sprenger MJW, Beyer WEP, Ament AJHA, Rutten FFH, Masurel N. Influenzavaccinatie leidt tot kostenbesparing in de gezondheidszorg. Tijdschr Soc Gezondheidszorg 1987; 65: 222-25

7 Nickol KL, Lofgren RP, Gapinsky J. Influenza vaccinations, knowledge, attidudes and behavior among high-risk outpatiënts. Arch Intern Med 1992; 152: 106-10

8 Eraker SA, Kirscht JP, Becker MH. Understanding and improving patient compliance. Ann Intern Med 1984; 100: 258-68

9 Ganguly R, Schler S, Vargas L, Cameron D, Chmel H, Benhke RH. Reasons for non-immunization against influenza in the aged. J Am Geriatr Soc 1989; 37: 387-93

10 Mostow SR, Schoenbaum SC, Dowdle WR, Coleman MT, Kaye HS. Studies with inactivated influenza vaccines purified by zonal centrifugation. I. Adverse reactions and serological response. Bull WHO 1969; 41: 525-30

11 Ruben FL, Jackson GG. A new subunit influenza vaccine: acceptability compared with standard vaccines and effect of dose on antigenicity. $J$ Infect Dis 1972; 125: 656-64

12 Mostow SR, Eickhof TC, Chelgren GA, Retaillau HF, Castle M. Studies of inactivated influenza virusvaccines in hospital employees: reactogenicity and absenteeism. J Infect Dis 1977; 136: 533-38

13 Margolis KL, Nichol KI, Poland GA, Pluhar RE. Frequency of adverse reactions to influenza vaccine in the elderly. A randomised, placebo controlled trial. JAMA 1990; 264: 1139-41

14 Margolis KL, Poland GA, Nichol KL, MacPherson DS, Meyer JD, Korn JE, Lofgren RP. Frequency of adverse reactions after influenza vaccination. Am J Med 1990; 88: 27-30

15 Scheifel DW, Bjornson G, Johnston J. Evaluation of adverse events after influenza vaccination in hospital personel. Can Med Assoc J 1990; 142: 127-30

16 Palache AM. Influenza vaccination. The effect of dose and age of the antibody response [Thesis]. Rotterdam: Erasmus Universiteit Rotterdam, 1991

17 Palache AM, Beyer WEP, Sprenger MJW, Masurel N, Jonge S de, Vardy A, et al . Antibody response after influenza immunization with various vaccine doses. A double blind, placebo controlled, multi-centre, dose-response study in elderly, nursing home residents and young volunteers. Vaccine 1992; 11: 3-9

18 Alling DW, Blackwelder WC. Stuart-Harris $\mathrm{CH}$. A study of excess mortality during influenza epidemics in the United States, 1968-1976. Am J Epidemiol 1981; 113: 30-43

19 Barker WH, Mullooly JP. Impact of epidemic, type A influenza in a defined adult population. Am J Epidemiol 1980; 112: 798-811

20 Barker WH, Mullooly JP. Pneumonia and influenza deaths during epidemics. Implications for prevention. Arch Intern Med 1982; 142: 85-89

21 Sprenger MJW, Mulder PGH, Beyer WEP, Strik R van, Masurel N. Impact of influenza on mortality regarding age and entity of underlying disease, during the period 1967 to 1989. Int J Epidemiol 1993; 22: 333-39

22 Sprenger MJW, Desmyter J, Masurel N. Minderheidsstandpunt over influenzavaccinatie bij ouderen. Ned Tijdschr Geneeskd 1991; 135: 2208-10

23 Gezondheidsraad: Commissie vaccinatie tegen influenza. Vaccinatie tegen influenza; seizoen 19911992. Den Haag: Gezondheidsraad, 1991/15

24 Parkman PD, Galasso GJ, Top FH, Noble GR. Summary of clinical trials of influenza vaccines. $J$ Infect Dis 1976; 134: 100-07

25 LaMontagne JR, Noble GR, Quinnan GV, Curlin GT, Blackwelder WC, Smith Jl, et al. Summary of clinical trials of inactivated influenza vaccine-1978. Rev Infect Dis 1983; 5: 723-36

26 Masurel N, Laufer J. A one-year study of trivalent influenza vaccines in primed and unprimed volunteers: immunogenicity, clinical reactions and protection. J Hyg 1984; 92: 263-76

27 Cate TR, Kasel JA, Couch RB, Six HR, Knight V. Clinical trials of bivalent influenza ANew Jersey/76- ANictoria/75 vaccines in the elderly. J Infect Dis. 1977; 136: 5518-25 


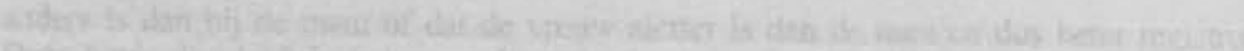

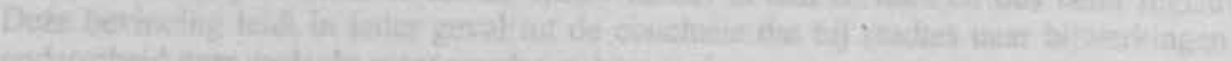

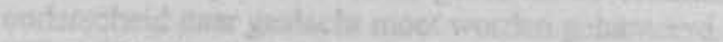

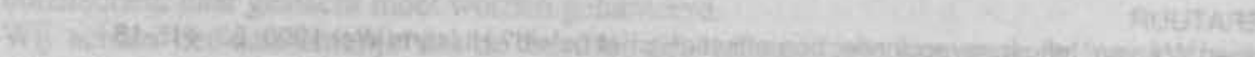

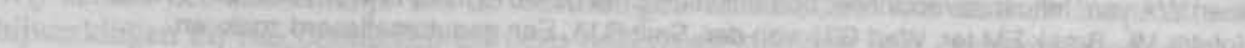
Ciefted

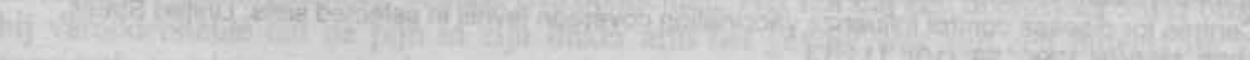

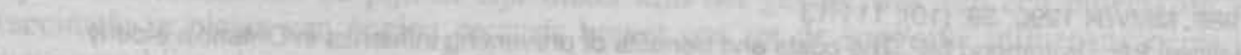

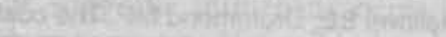

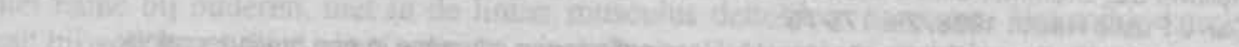

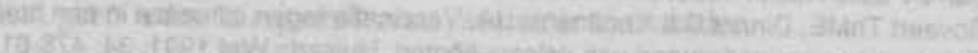

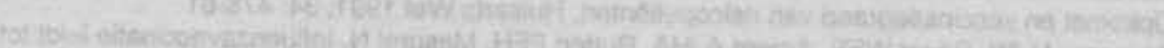

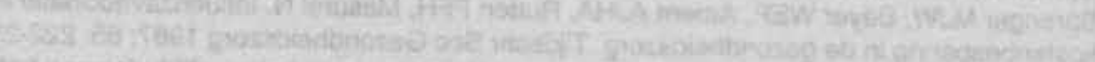

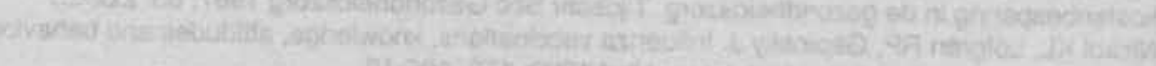

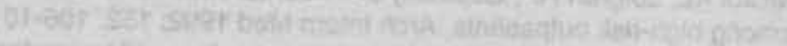

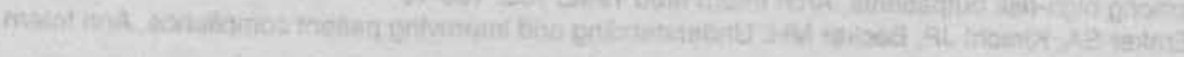

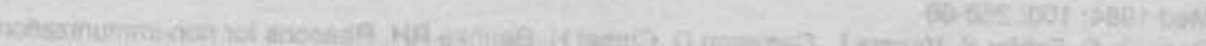

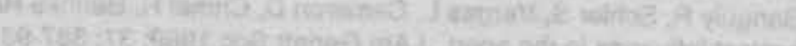

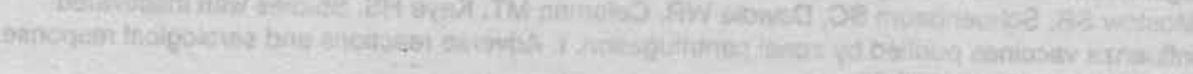

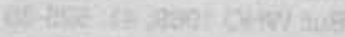

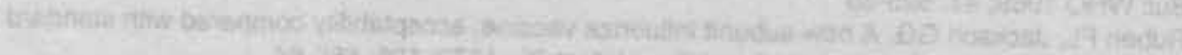

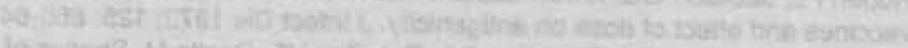

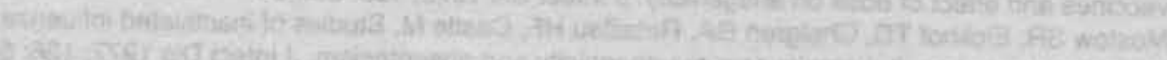

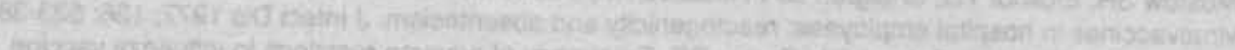

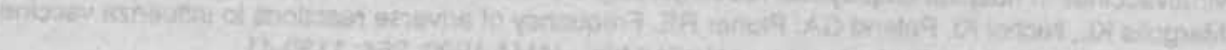

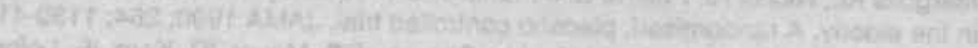

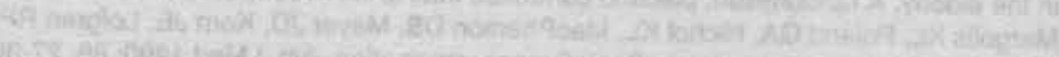

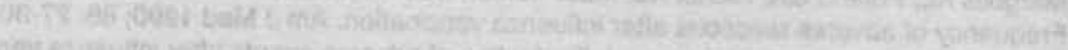

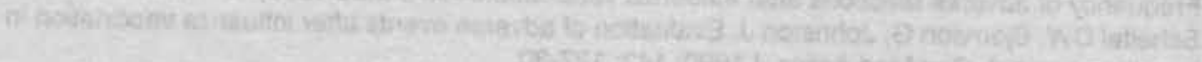

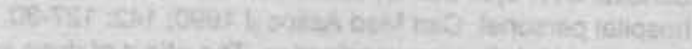

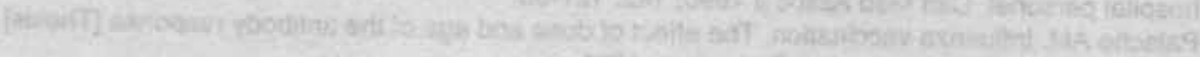

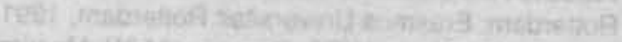

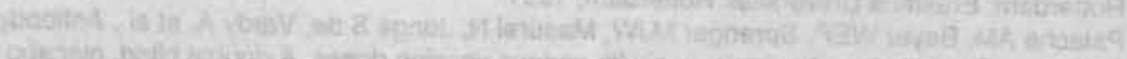

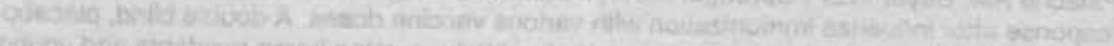

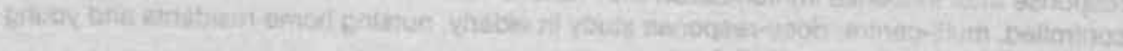

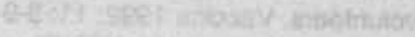

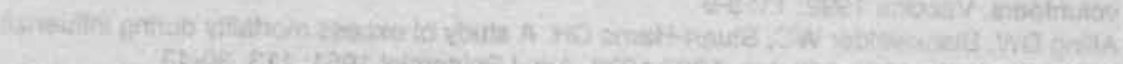

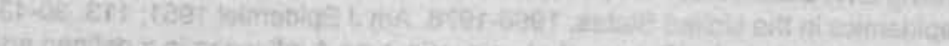

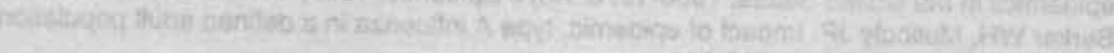

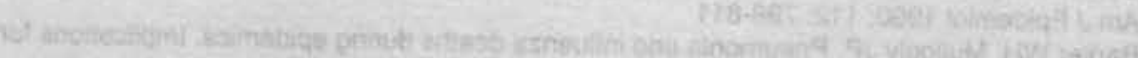

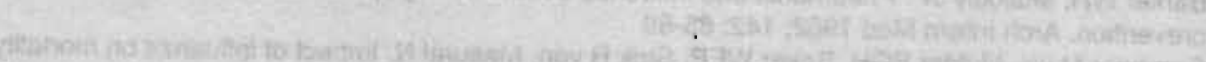

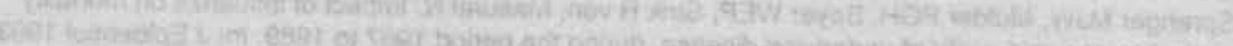
rat

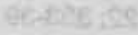

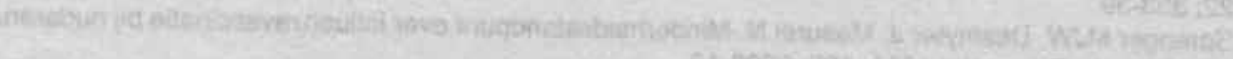

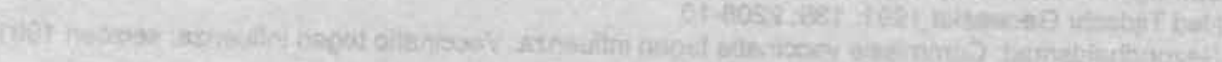

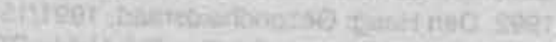

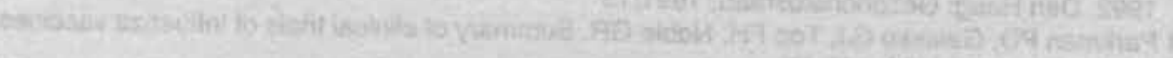

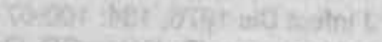

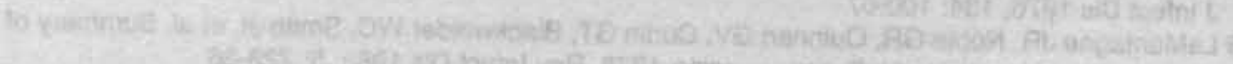

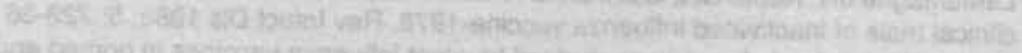

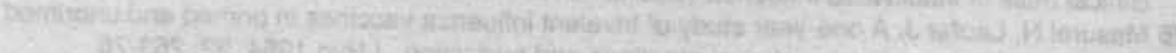

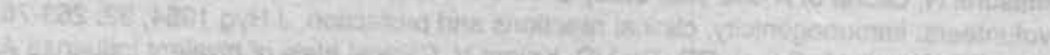

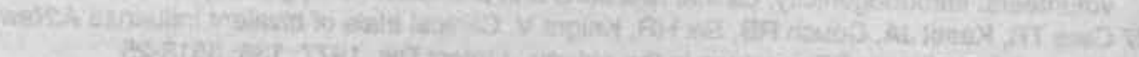

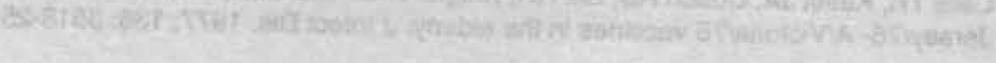




\section{HOOFDSTUK 10}

\section{IMMUUNRESPONS OP INFLUENZAVACCINATIE BIJ OUDEREN:}

een gerandomiseerde, dubbelblinde, placebo-gecontroleerde studie

Th.M.E. Govaert, M.J.W. Sprenger, G.J.Dinant, K. Aretz,

N. Masurel, J.A. Knottnerus

Geaccepteerd voor publicatie in Vaccine 


\section{SAMENVATTING}

Doel. Bepalen van de immuunrespons op influenzavaccinatie bij ouderen.

Opzet. Gerandomiseerde, dubbelblinde, placebo-gecontroleerde studie.

Methode. Bij 1838 personen in de leeftijd van 60 jaar en ouder werd, voorafgaande aan een injectie met influenzavaccin of placebo, veneus bloed afgenomen. Drie weken later werd een tweede bloedmonster afgenomen. De antilichaamreactie werd bepaald door het vergelijken van de geometrisch gemiddelde titer en het percentage deelnemers met een beschermende antilichaamtiter vóór en ná vaccinatie, voor alle sera van een stam.

Resultaten. Een beschermende antilichaamtiter werd gevonden bij $43 \%$ tot $68 \%$ der gevaccineerden, afhankelijk van de onderzochte stam. Potentiële risicopatiënten vertoonden een zelfde immuunrespons als de overige deelnemers.

Conclusie. Influenzavaccinatie bij oudere mensen biedt een redelijke tot goede immuunrespons. Verder onderzoek is nodig om het effect van een goede immuunrespons op de incidentie van influenza te evalueren.

Sleutelwoorden: influenzavaccinatie, immuunrespons, risicopatiënten, ouderen. 


\section{INLEIDING}

Influenzavaccinatie wordt in de meeste landen aanbevolen bij personen met risicofactoren zoals hart- vaat- en longziekten, suikerziekte en personen ouder dan 60 jaar $(1,2)$. In het verleden is een aantal studies gedaan naar de effectiviteit van influenzavaccinatie bij verschillende populaties (3-11). De resultaten van deze studies kunnen wegens methodologische verschillen moeilijk met elkaar vergeleken worden (12-22). De studies zijn meestal retrospectief of observationeel uitgevoerd en serologische bepalingen werden zelden gedaan. Uit meerdere vaccinatiestudies bleek dat ouderen minder beschermnd waren tegen influenza dan jongeren $(17,19)$. Echter niet iedereen deelt deze mening (21). In de onderhavige studie onderzoeken wij de vraag wat het immunologische effect van influenzavaccinatie is bij oudere personen, waaronder eventuele risicopatiënten. Onderzoek bij risicopatiënten is moeilijk uitvoerbaar; vaak moeten deze patiënten om medische redenen uitgesloten worden. Ook kunnen zich medisch-ethisch bezwaren voordoen indien risicopatiënten of patiënten die voorheen steeds werden gevaccineerd, deelnemen aan een gerandomiseerd. onderzoek.

Door middel van een gerandomiseerde, dubbelblinde, placebo- gecontroleerde studie is getracht in een doorsnee populatie van 60 jaar en ouder, met uitsluiting van door de huisarts erkende risicopatiënten, de immuunrespons te bepalen na vaccinatie met een gangbaar influenzavaccin. Hierbij werd ook de invloed van het mogelijk behoren tot een risicogroep, de leeftijd, het geslacht en het al of niet eerder gevaccineerd zijn, op de immuunrespons bestudeerd.

\section{METHODE}

\section{Patiënten}

Aan het onderzoek, uitgevoerd in het seizoen 1991-'92, namen 34 huisartsen uit 15 huisartspraktijken deel. De totale populatie van deze praktijken bedroeg 68.988 patiënten. Uitgesloten van het onderzoek werden patiënten die door de huisarts geacht werden te behoren tot een risicogroep volgens het advies van de Gezondheidsraad (2), alsmede patiënten die verbleven in verzorgings- en verpleegtehuizen. Van de resterende groep werden alle personen van 60 jaar en ouder uitgenodigd voor deelname aan het onderzoek. Van de 9907 uitgenodigde personen stemden $1838(18,6 \%)$ in met deelname: 869 mannen $(47,3 \%)$ en 969 vrouwen $(52,7 \%$ ). De gemiddelde leeftijd was 67 jaar (standaard deviatie 6 ; mediaan 66) en de range liep van 60 tot 91 jaar. Over de samenstelling van de non-respons groep zijn geen nadere gegevens beschikbaar. Velen antwoordden niet of vulden het antwoordformulier in zonder toelichting op hun weigering. Uit de resterende informatie en uit telefonische toelichtingen kan worden geconcludeerd dat de drie belangrijkste redenen voor weigering waren: angst voor de injectie, angst voor de bloedafname en de gebondenheid in tijd gedurende de periode van het onderzoek. Tien procent van de deelnemers gaf aan in 1989 en 1990 te zijn gevaccineerd tegen influenza. Zevenentwintig procent van de deelnemers bleek alsnog cardiologische, pulmonale of stofwisselings problematiek te hebben. Deze was naar het oordeel van de eigen huisarts echter niet van dien aard dat vaccinatie was aangewezen. Bij de deelnemende artsen bleek er een verschillende interpretatie te zijn van het begrip risicopatiënt. Ook was het vaccinatiebeleid van de artsen niet hetzelfde (vaccinatie via oproep van de arts of op initiatief van de patiënt). Om de invloed van de risicostatus op de mate van immuunrespons te beoordelen, werden de deelnemers ingedeeld in de volgende categorieën: hartaandoeningen, longaandoeningen, diabetes mellitus en overige personen.

\section{Procedure}

Als vaccin werd gebruikt het gezuiverd split-vaccin geproduceerd door Evans Medical Ltd, 
Langhurst, Horsham, England. Dit vaccin was, evenals de andere in Nederland verkrijgbare griepvaccins, samengesteld volgens de richtlijnen van de World Health Organisation en de Gezondheidsraad. Elke dosis bevatte: A/Singapore/6/86 (H1N1), A/Beijing/353/89 (H3N2), $\mathrm{B} /$ Panama/45/90 en $\mathrm{B} / \mathrm{Be} i \mathrm{jing} / 1 / 87$, allen equivalent met 15 microgram hemagglutinine. Als placebo werd fysiologisch zout gebruikt.

Tussen 1 en 15 november 1991 werd van alle deelnemers, voorafgaande aan de injectie met vaccin of placebo, 9 milliliter veneus bloed afgenomen (S1). Het vaccin of placebo werd door drie ervaren huisartsen intramusculair in de linker of rechter musculus deltoideus toegediend volgens een gestratificeerd randomisatieschema. Er werden vier strata geformeerd volgens de bovengenoemde categorieën van aandoeningen.

Drie weken na de eerste bloedafname werd bij alle deelnemers een tweede monster veneus bloed afgenomen (S2). Het interval tussen afname van S1 en S2 was in vaccin- en placebogroep voor de totale onderzoekpopulatie en de subgroepen niet verschillend. Een derde bloedmonster (S3) werd 5 maanden na S1 afgenomen. De sera van deze bloedmonsters werden bij $-20^{\circ} \mathrm{Celsius}$ bewaard en na het beëindigen van de studieperiode voor verdere analyse vervoerd naar het Nationaal Influenza Centrum te Rotterdam. Ieder serum was voorzien van een uniek nummer, gekoppeld aan de patiënt.

\section{Laboratorium bepalingen}

De bepaling van de antilichaamtiters in de sera werd gedaan met behulp van de hemagglutinatie remmingstest. Influenza virusstammen werden gekweekt in 12 dagen oude geëmbryoneerde kippeëieren. Voor de titraties werden de stammen van of analoog aan het vaccin gebruikt. Wegens de zwakke werking van de influenza B virussen werden de met deze stam geïnfecteerde eieren behandeld met ether (23). De aldus verkregen vloeibare fase werd gebruikt voor de serologische tests. De antilichaamtiter vóór en ná vaccinatie werden door twee analistes onafhankelijk van elkaar, tegelijkertijd, volgens standaardmethoden bepaald (5). De titers werden uitgedrukt als de omgekeerde waarden van de verdunning waarbij $50 \%$ hemagglutinine remming plaats vond na toevoeging van 3 eenheden hemagglutinine van het antigeen. Voor titers lager dan 9 werd het getal 5 gebruikt. Volgens deze methode is bescherming tegen influenza door influenza A-stammen aanwezig bij een antilichaamtiter $\geq 100$ (6). Van de met ether behandelde influenza B-stammen is een dergelijke beschermingswaarde niet bekend. In navolging van eerdere studies werd hiervoor een antilichaamtiter $\geq 200$ genomen (7).

\section{Statistische analyse}

Van de door beide analistes in duplo bepaalde serumtiters werd de gemiddelde logaritmische titerwaarde per serum berekend. Uit deze gemiddelde logaritmische titerwaarde werd de geometrisch gemiddelde titer (GMT) bepaald voor alle sera van de samples 1 en 2 voor iedere stam apart met de daarbij behorende betrouwbaarheidsintervallen (BI). De beschermingsgraad (protection rate [PR]) werd gedefinieerd als het percentage deelnemers dat een antilichaamtiter had $\geq 100$ voor de A-stammen en $\geq 200$ voor de B-stammen. Uit eerdere publicaties is gebleken dat de GMT en PR de belangrijkste parameters zijn voor een schatting van de immuunrespons op vaccinatie $(4,22)$. De berekeningen van GMT en PR werden ook uitgevoerd voor wél (in 1989 en 1990) en niet eerder gevaccineerden.

Indien vóór vaccinatie reeds een hoge titer van antilichamen aanwezig is, kan dit de titerhoogte van antilichamen na vaccinatie beïnvloeden $(24,25)$. Daarom werd met behulp van bivariate regressie-analyse de invloed van de logaritmische titer van S1 op S2 nagegaan, en S2 werd hiervoor gecorigeerd. De gebruikte formule was als volgt:

$S 2$ corr $1=S 2-C(S 1-\log 10)$ waarin:

$\mathrm{S} 2$ corr 1 = de voor $\mathrm{S} 1$ gecorrigeerde titer $\mathrm{S}$,

$\mathrm{C}=$ regressiecoëfficient van het bivariate regressiemodel

S1 en S2 de logaritmen van de respectievelijke titers zijn. 
De invloed van de onafhankelijke variabelen $S 1$, leeftijd, geslacht, vaccinatiestatus (vaccin/placebo), risicostatus en het al of niet eerder gevaccineerd zijn, op de GMT en PR voor al of niet eerder gevaccineerden, werd met behulp van een multipele lineaire regressieanalyse voor de GMT en een logistische regressie-analyse voor de PR bestudeerd. Dit werd gedaan voor iedere stam apart. Een titer $\geq 38$ en een 4-voudige titerstijging in S3 ten opzichte van S2 corr l werd bewijzend geacht voor een doorgemaakte infectie van influenza (26). De analyses werden verricht op een VAX-Mainframe computer, met behulp van het programma BMDP, versie 1990.

Goedkeuring medisch ethische commissie

Het protocol werd goedgekeurd door de medisch-ethische commissie van de Rijksuniversiteit Limburg en het Academisch Ziekenhuis Maastricht. Door alle deelnemers werd een "informed consent" ondertekend.

\section{Tabel 10.1 Samenstelling onderzoekpopulatie (n=1838) *.}

\begin{tabular}{|c|c|c|c|c|}
\hline \multirow[t]{2}{*}{ Subgroepen } & \multicolumn{2}{|c|}{ Vaccin $(\mathrm{n}=927)$} & \multicolumn{2}{|c|}{ Placebo $(n=911)$} \\
\hline & $\mathbf{n}$ & $\%$ & $\mathbf{n}$ & $\%$ \\
\hline \multicolumn{5}{|l|}{ Potentiële risicostatus } \\
\hline Hartaandoeningen & 125 & 13,5 & 124 & 13,6 \\
\hline Longaandoeningen & 105 & 11,3 & 95 & 10,4 \\
\hline Diabetes mellitus & 21 & 2,3 & 20 & 2,2 \\
\hline Overigen/gezonden & 676 & 72,9 & 672 & 73,8 \\
\hline Totaal & 927 & 100 & 911 & 100 \\
\hline \multicolumn{5}{|l|}{ Geslacht } \\
\hline Man & 420 & 45,3 & & 49,3 \\
\hline Vrouw & 507 & 54,7 & 462 & 50,7 \\
\hline Totaal & 927 & 100 & 911 & 100 \\
\hline \multicolumn{5}{|l|}{ Leeftijd } \\
\hline $60-64$ & 368 & 39,7 & 396 & 43.5 \\
\hline $65-69$ & 281 & 30,3 & 249 & 27.3 \\
\hline $70-74$ & 176 & 19,0 & 177 & 19,4 \\
\hline $75-79$ & 66 & 7,1 & 61 & 6,7 \\
\hline $80-84$ & 29 & 3,1 & 19 & 2,1 \\
\hline $85-91$ & 7 & 0,8 & 9 & 1,0 \\
\hline Totaal & 927 & 100 & 911 & 100 \\
\hline \multicolumn{5}{|l|}{ Eerder gevaccineerd } \\
\hline & 118 & 12,7 & 120 & 13,2 \\
\hline Nee & 809 & 87,3 & 791 & 86,8 \\
\hline Totaal & 927 & 100 & 911 & 100 \\
\hline \multicolumn{5}{|c|}{ Beschermende titer in S1 tegen } \\
\hline A/Singapore/6/86 (H1N1) & 29 & 3,1 & 23 & 2,5 \\
\hline A/Beijing/353/89 (H3N2) & 21 & 2,3 & 28 & 3,1 \\
\hline B/Panama/45/90 & 73 & 7,9 & 60 & 6,6 \\
\hline B/Beijing/1/87 & 95 & 10,3 & 88 & 9,7 \\
\hline
\end{tabular}

* gemiddelde leeftijd 67 jaar (SD 6, mediaan 66) 


\section{RESULTATEN}

De samenstelling van de onderzoekpopulatie wordt weergegeven in Tabel 10.1. Het aantal gevaccineerden en niet gevaccineerden was nagenoeg gelijk verdeeld in de subgroepen risicopatiënten, mannen, vrouwen, leeftijd en voorafgaande vaccinatiestatus. Uit de bivariate regressie analyse bleek dat de logaritmische titer van S2 positief gecorreleerd was met die van S1. Hiervoor werd gecorrigeerd.

\begin{tabular}{|c|c|c|c|c|c|c|c|}
\hline \multicolumn{4}{|c|}{ Tabel 10.2} & \multicolumn{4}{|c|}{$\begin{array}{l}\text { uitgedrukt in GMT en PR van met placebo } \\
\text { gevaccineerde deelnemers vóor en ná }\end{array}$} \\
\hline \multirow[b]{2}{*}{ Stam } & \multicolumn{3}{|c|}{ Placebo } & \multicolumn{2}{|r|}{ Vaccin } & \multicolumn{2}{|c|}{$\begin{array}{c}\text { p-waarde GMT } \\
\text { placebo versus vaccin }\end{array}$} \\
\hline & Aant: & $\begin{array}{l}\text { al* GMT } \\
\text { vóór/ná }\end{array}$ & $\begin{array}{c}\text { PR } \\
\text { vóór/ná }\end{array}$ & Aantal* & $\begin{array}{l}\text { GMT } \\
\text { vó́r /ná }\end{array}$ & $\begin{array}{c}\text { PR } \\
\text { vớór/ná }\end{array}$ & vớr/nả \\
\hline${ }_{\mathrm{BI}}$ & 898 & $\begin{array}{c}7 / 11 \\
(7-8 / 10-11)\end{array}$ & $3 / 2$ & 907 & $\begin{array}{c}8 / 73 \\
(7-8 / 66-82)\end{array}$ & $3 / 43$ & $0,47 /<0,001$ \\
\hline${ }_{\mathrm{BI}}^{\mathrm{AB}}$ & 898 & $\begin{array}{c}10 / 12 \\
(9-10 / 11-12)\end{array}$ & $3 / 3$ & 907 & $\begin{array}{c}9 / 217 \\
-10 / 194-245)\end{array}$ & $2 / 68$ & $0,36 /<0,001$ \\
\hline${ }_{\text {BI }}^{\text {BP }}$ & 899 & $\begin{array}{c}19 / 14 \\
(17-21 / 13-14)\end{array}$ & $7 / 2$ & 907 & $\begin{array}{c}20 / 194 \\
8-22 / 179-211)\end{array}$ & $8 / 47$ & $0,47 /<0,001$ \\
\hline${ }_{\mathrm{BI}}^{\mathrm{BB}}$ & 900 & $\begin{array}{c}20 / 14 \\
(18-23 / 13-14)\end{array}$ & $10 / 2$ & $907 \quad(18$ & $\begin{array}{c}20 / 169 \\
8-22 / 154-186)\end{array}$ & $10 / 45$ & $0,47 /<0,001$ \\
\hline
\end{tabular}

\begin{tabular}{|c|c|}
\hline $\begin{array}{l}\mathrm{AS}: \\
\mathrm{AB}: \\
\mathrm{BP}: \\
\mathrm{BB}:\end{array}$ & $\begin{array}{l}\text { A/Singapore/6/86 (H1N1) } \\
\text { A/Beijing/353/89 (H3N2) } \\
\text { B/Panama/45/90 } \\
\text { B/Beijing/1/87 }\end{array}$ \\
\hline & $\begin{array}{l}\text { Deelnemers waarvan de laboratorium gegevens niet volledig waren, werden } \\
\text { uitgesloten }\end{array}$ \\
\hline $\mathrm{M}^{\prime}$ & $\begin{array}{l}\text { Geometrische gemiddelde titer van alle samples } 1 \text { (vóór vaccinatie), respectievelijk } \\
\text { samples } 2 \text { (ná vaccinatie). }\end{array}$ \\
\hline & $\begin{array}{l}\text { Protection rate: het percentage deelnemers met een beschermende antilichaamtiter } \\
95 \% \text { betrouwbaarheidsinterval }\end{array}$ \\
\hline & etst met behulp van de Mann-Whitney tests \\
\hline
\end{tabular}

De antilichaamstatus van de deelnemers vóór en ná de toediening van placebo respectievelijk vaccin wordt getoond in tabel 10.2. Er bleek een statistisch significante stijging van de antilichaamtiter op te treden, zowel wat GMT als PR betreft, bij met vaccin gevaccineerde deelnemers in tegenstelling tot de deelnemers die placebo ontvingen.

De invloed van de voorafgaande vaccinatiestatus op de immuunrespons wordt weergegeven in tabel 10.3. Hierbij is behalve naar de immuunrespons bij alle met vaccin gevaccineerden ook gekeken naar de respons bij mannen, vrouwen en potentiële risicopatiënten apart. De subgroepen hart- long- en suikerpatiënten zijn niet apart weergegeven. Zij vertoonden allen eenzelfde patroon als de potentiële risicogroep als geheel. Bij de voorafgaande twee jaren 
Tabel 10.3 Invloed van voorafgaande vaccinatiestatus op de immuunrespons bij gevaccineerden $(\mathrm{n}=927)$ verdeeld over verschillende subgroepen (zie voetnoot).

\begin{tabular}{|c|c|c|c|c|c|c|c|c|c|c|c|}
\hline \multirow[t]{3}{*}{ Stam } & & \multicolumn{10}{|c|}{ Gevaccineerd in 1989 and ' 90} \\
\hline & & \multicolumn{5}{|c|}{$\mathrm{Ja}(\mathrm{n}=118)^{*}$} & \multicolumn{5}{|c|}{ Nee $(n=788)^{*}$} \\
\hline & & Aantal* & GMT voor/na & p-waarde & PR voor/na & p-waarde & Aantal* & GMT voor/na & p-waarde & PR voor/na & $\mathrm{p}$-waarde \\
\hline \multirow[t]{4}{*}{ AS } & $T$ & 118 & $30 / 42$ & 0,37 & $18 / 20$ & 0,76 & 788 & $6 / 80$ & $S$ & $1 / 47$ & $\mathrm{~S}$ \\
\hline & $M$ & 47 & $25 / 36$ & 0,50 & $17 / 19$ & 0,81 & 365 & $6 / 76$ & $S$ & $1 / 45$ & $\mathrm{~S}$ \\
\hline & V & 71 & $35 / 47$ & 0,62 & $18 / 20$ & 0,84 & 423 & $6 / 83$ & S & $1 / 48$ & $\mathrm{~S}$ \\
\hline & $\mathbf{R}$ & 57 & $30 / 48$ & 0,33 & $16 / 25$ & 0,30 & 187 & $7 / 83$ & S & $2 / 50$ & $\mathrm{~S}$ \\
\hline \multirow[t]{4}{*}{$A B$} & $\mathrm{~T}$ & 118 & $35 / 119$ & $S$ & $14 / 52$ & $S$ & 788 & $7 / 241$ & $S$ & $1 / 70$ & $S$ \\
\hline & M & 47 & $29 / 112$ & $S$ & $9 / 49$ & $S$ & 365 & $8 / 221$ & S & $1 / 69$ & $\mathrm{~S}$ \\
\hline & V & 71 & $39 / 112$ & $S$ & $17 / 54$ & $S$ & 423 & $7 / 260$ & $S$ & $0 / 71$ & $\mathrm{~S}$ \\
\hline & $\mathbf{R}$ & 57 & $13 / 117$ & $\mathrm{~S}$ & $12 / 54$ & $\mathrm{~S}$ & 187 & $8 / 256$ & S & $2 / 73$ & $S$ \\
\hline \multirow[t]{4}{*}{$\overline{\mathrm{BP}}$} & $\mathrm{T}$ & 118 & $138 / 98$ & $S$ & $37 / 19$ & $S$ & 778 & $15 / 215$ & $\bar{S}$ & $4 / 51$ & $S$ \\
\hline & M & 47 & $128 / 79$ & 0,02 & $30 / 15$ & 0,11 & 365 & $18 / 196$ & $S$ & $4 / 49$ & $S$ \\
\hline & V & 71 & $146 / 113$ & 0,06 & $41 / 21$ & 0,03 & 423 & $13 / 233$ & $\mathrm{~S}$ & $3 / 53$ & $\mathrm{~S}$ \\
\hline & $\mathbf{R}$ & 57 & $149 / 99$ & 0,03 & $35 / 19$ & 0,09 & 187 & $17 / 234$ & S & $3 / 54$ & S \\
\hline \multirow[t]{4}{*}{$\mathrm{BB}$} & $\mathrm{T}$ & 118 & $120 / 59$ & $S$ & $37 / 10$ & $S$ & 788 & $16 / 197$ & $\mathrm{~S}$ & $6 / 51$ & $S$ \\
\hline & M & 47 & $158 / 48$ & $S$ & $45 / 4$ & $S$ & 365 & $18 / 190$ & $S$ & $9 / 49$ & $\mathrm{~S}$ \\
\hline & V & 71 & $100 / 68$ & 0,02 & $32 / 14$ & 0,02 & 423 & $13 / 202$ & $S$ & $5 / 53$ & $\mathrm{~S}$ \\
\hline & $\mathbf{R}$ & 57 & $154 / 59$ & $S$ & $46 / 5$ & $S$ & 187 & $17 / 201$ & $\mathrm{~S}$ & $9 / 49$ & $S$ \\
\hline
\end{tabular}

AS: A/Singapore/6/86 (HIN1); AB: A/Beijing/353/89 (H3N2); BP: B/Panama/45/90; $\quad$ BB: B/Beijing/1/87

GMT: Geometrische gemiddelde titer van alle samples 1, respectievelijk samples 2

PR: Protection rate; het percentage deelnemers met een beschermende antilichaamtiter

* Deelnemers waarvan de laboratoriumgegevens niet volledig waren, werden uitgesloten

T: Totaal aantal eerder respectievelijk niet eerder gevaccineerden; $\quad$ M: Mannen; $\quad$ V: Vrouwen; $\quad$ R: Risicopatiënten p-waarde: p-waarde GMT vóór en ná vaccinatie (Wilcoxon toets) en p-waarde PR vóór en ná vaccinatie (McNemar toets voor gepaarde waarnemingen)

으 $\quad \mathrm{S}$ : $\mathrm{p}$-waarde $<0,01$ 
niet gevaccineerden bleek er in alle onderzochte subgroepen een forsere stijging te zijn van GMT en PR na vaccinatie dan bij de deelnemers die de voorafgaande twee jaren reeds gevaccineerd waren geweest. Dit verschil was statistisch significant.

De multipele regressie-analyse bevestigde het geschetste beeld, namelijk dat de vaccinatiestatus (vaccin/placebo) voor alle stammen een sterke, statistisch significante invloed heeft op de immuunrespons, zowel in termen van GMT als PR, en dat, onafhankelijk hiervan, het in de vorige twee jaren reeds gevaccineerd zijn steeds een significant negatieve invloed op de immuunrespons heeft. Een eveneens onafhankelijke, maar zeer geringe invloed heeft een hogere leeftijd op de immuunrespons voor de stammen A/Singapore en B/Beijing. De bijbehorende lineaire regressie coëfficiënten voor de GMT bedragen respectievelijk 0,007 (SE: 0,002 ) en 0,004 (SE: 0,002 ), per jaar leeftijdstoename. De door middel van logistische regressie gecorrigeerde odds ratio's voor de PR coëfficiënten bedragen voor A/Singapore en B/Beijing respectievelijk 0,96 (95\% BI: 0,94-0,99) en 0,97 (95\% BI: 0,95-1,00), eveneens per jaar leeftijdstoename. De variabele geslacht en risicostatus heeft geen invloed. De genoemde effecten zijn onafhankelijk van en gecorrigeerd voor S1.

Bij de deelnemers die de voorafgaande twee jaren ook gevaccineerd waren $(n=117,1$ uitvaller) werd bij $0,9 \%$ serologisch influenza aangetoond terwijl dit percentage bij de nooit eerder gevaccineerden ( $n=784,4$ uitvallers) $5,1 \%$ bedroeg $(p=0,04)$.

\section{BESCHOUWING}

Een beschermende antilichaamtiter ten gevolge van vaccinatie werd, afhankelijk van de onderzochte stam, in dit onderzoek gevonden bij $43 \%$ tot $68 \%$ der deelnemers. Potentiële risicopatiënten (patiënten met hart- vaataandoeningen, longaandoeningen of diabetes mellitus) vertoonden een vergelijkbare immuunrespons als de overige deelnemers. Gezien de overeenkomst in aandoeningen bij de in dit onderzoek opgenomen potentiële risicogroepen en de als zodanig reeds te boek staande risicopatiënten, is het aannemelijk dat in een doorsnee bevolking van 60 -jarigen en ouder influenzavaccinatie een redelijke tot goede immuunrespons oplevert. Naarmate de deelnemers ouder waren werd er een geringer verschil in immuunrespons gevonden tussen we! en niet eerder gevaccineerden, althans voor een tweetal stammen (A/Singapore en B/Beijing).

Literatuurgegevens over immuunrespons na vaccinatie zijn tegenstrijdig. De door vaccinatie behaalde beschernningsgraad varieerde hierin van $0-80 \%(4,6-8,17,19,21,22)$. In een recent overzichtsartikel van publicaties tussen de jaren 1968-'88 werden 17 studies geselecteerd die redelijk voldeden aan de gestelde criteria van goed onderzoek (22). In deze 17 publicaties kon in 30 gevallen de vaccinsamenstelling in relatie tot een immuunrespons bestudeerd worden. Bij 10 hiervan werd een betere respons gevonden bij jongeren dan bij ouderen, bij 4 werd het omgekeerde gevonden en bij 16 kon geen verschil worden gevonden tussen beide groepen. Een dergelijke divergentie van bevindingen werd verklaard door mogelijke methodologische tekortkomingen van deze studies. Veelal betrof he! geïnstitutionaliseerde oude mensen met multipele pathologie en uitgebreide medicatie. Men neemt aan dat het immunologisch systeem bij ouderen minder effectief functioneert, hoewel deze mening niet door iedereen wordt gedeeld $(17,19,21)$. Ook werd vaak geen rekening gehouden met de voorafgaande vaccinatiestatus. Indien vóór vaccinatie een hoge antilichaamtiter tegen een bepaalde stam aanwezig is, kan dit de aanmaak van nieuwe antilichamen beïnvloeden $(24,25)$. De samenstelling van de in deze studie onderzochte populatie was een goede weerspiegeling van een doorsnee bevolking van 60 jaar en ouder, met uitsluiting van door de huisarts erkende risicopatiënten. Er is in deze studie geen vergelijking gemaakt met jongeren. De genoemde tekortkomingen in eerdere studies (geïnstitutioneerde ouderen, voorafgaande vaccinstatus) waren hier niet aanwezig.

Er werd voor alle 4 stammen een duidelijke stijging gevonden van de immuunrespons na 


\begin{tabular}{|c|c|c|c|}
\hline Tabel 10.4 & $\begin{array}{l}\text { Overzicht van de stamm } \\
\text { virale stammen geduren }\end{array}$ & $\begin{array}{l}\text { let influenzavacci } \\
\text { eizoenen } 1989 / 90\end{array}$ & $\begin{array}{l}\text { circulerende } \\
92(25) \text {. }\end{array}$ \\
\hline$\overline{\text { Seizoen }}$ & Samenstelling vaccin & $\begin{array}{l}\text { Circulerende virale } \\
\text { stammen }\end{array}$ & $\begin{array}{l}\text { Antigene } \\
\text { overeenkomst }\end{array}$ \\
\hline $1989 / 90$ & $\begin{array}{l}\text { A/Shanghai/11/87(H3N2) } \\
\text { A/Taiwan/1/86(H1N1) } \\
\text { B/Yamagata/16/88 }\end{array}$ & $\begin{array}{l}\text { A/Shanghai/11/87 } \\
\text { A/Taiwan/1/86 } \\
\text { B/Yamagata/16/88 } \\
\text { B/Victoria/2/87 }\end{array}$ & $\begin{array}{l}\text { ja } \\
\text { ja } \\
\text { ja }\end{array}$ \\
\hline 1990/91 & $\begin{array}{l}\text { A/Guizhou/54/89(H3N2) } \\
\text { A/Taiwan/1/86(H1N1) } \\
\text { B/Yamagata/16/88 } \\
\text { B/Beijing/1/87 }\end{array}$ & $\begin{array}{l}\text { A/Beijing/353/89 } \\
\text { A/Taiwan/1/86 } \\
\text { B/Yamagata/16/88 }\end{array}$ & $\begin{array}{l}\mathrm{ja} \\
\mathrm{ja} \\
\mathrm{ja}\end{array}$ \\
\hline $1991 / 92$ & $\begin{array}{l}\text { A/Beijing/353/89(H3N2 } \\
\text { A/Singapore/6/86(H1N1) } \\
\text { B/Panama/45/90 } \\
\text { B/Beijing/1/87 }\end{array}$ & $\begin{array}{l}\text { A/Beijing/353/89 } \\
\text { A/Taiwan/1/86 } \\
\text { B/Panama/45/90 }\end{array}$ & $\begin{array}{l}\text { ja } \\
\text { ja } \\
\text { ja }\end{array}$ \\
\hline
\end{tabular}

vaccinatie. Opvallend is dat van de vier stammen in het vaccin de stam A/Beijing duidelijk een hogere antilichaamtiter heeft na vaccinatie. Een mogelijke verklaring zou kunnen zijn dat in de voorafgaande jaren deze stam niet identiek was aan de gebruikte stammen in het vaccin, noch een goede antigeenovereenkomst had met de circulerende virale stammen (tabel 10.4).

Hoskins et al. vond dat herhaalde vaccinatie een verminderde bescherming tegen influenza zou geven (27). Om die reden wordt geadviseerd personen die de laatste jaren reeds gevaccineerd zijn niet in een serologische analyse van de immuunrespons op te nemen $(5,6,22,28)$. Een reeds bestaande hoge antilichaamtiter kan een serologische reactie beïnvloeden $(24,25)$. Ook in dit onderzoek werd een duidelijk lagere immuunrespons gevonden bij eerder gevaccineerden ten opzichte van niet eerder gevaccineerden. De verminderde immuunrespons bij eerder gevaccineerden was onafhankelijk van geslacht en risicofactoren. Desondanks vonden wij bij eerder gevaccineerden statistisch significant serologisch minder influenza $(0,9 \%)$ dan bij de deelnemers die voor de eertse keer werden gevaccineerd $(5,1 \%)$. GMT en PR zijn parameters van de humorale immuniteit, terwijl er waarschijnlijk ook een cellulaire immuniteit tegen influenza bestaat. Het is aannemelijk dat zowel de humorale als de cellulaire immuniteit het effect van influenzavaccinatie bepalen. Concluderend menen wij te mogen stellen dat influenzavaccinatie bij ouderen en oudere potentiële risicopatiënten een redelijk tot goede immuunrespons oplevert, afhankelijk van de onderzochte stam. Of een goede immuunrespons de incidentie van influenza doet afnemen zal nader onderzocht dienen te worden. 
2 Gezondheidsraad: Commissie vaccinatie tegen influenza. Vaccinatie tegen influenza; seizoen 1991-1992. Den Haag: Gezondheidsraad, 1991/15

3 Gross PA, Quinnan GV, Rodstein M, Lamontagne JR, Kaslow RA, Saah AJ, et al. Association of influenza immunization with reduction in mortality in an elderly population, a prospective study. Arch Intern Med 1988; 148: 562-65

4 Palache AM, Beyer WEP, Sprenger MJW, Maurel N, Jonge S de, Vardy A, et al. Antibody response after influenza immunization with various vaccine doses: a double blind placebo controlled, multicentre, dose-response study in elderly nursing-home residents and young volunteers. Vaccine 1993; 11: $3-9$

5 Masurel N, Ophof B, Jong P de. Antibody respons to immunization with influenza AVSSR/77 (H1N1) virus in young individuals primed or unprimed for A/New Jersey/76 (H1N1) virus. J Hyg 1981; 87: 201-09

6 Masurel N, Laufer J. A one year study of trivalent influenza vaccines in primed and unprimed volunteers: immunogenicity, clinical reactions and protection. J Hyg 1984; 92: 263-76

7 Beyer WEP, Teunissen MWE, Diepersloot RJA, Masurel N. Immunogenicity and reactogenicity of two doses of trivalent influenza split vaccine. An open randomized study in healthy, unprotected, adult volunteers. J Drug Ther Res 1986; 11: 369-74

8 Mostow SR, Schoenbaum SC, Dowdle WR, Coleman MT, Kaye HS. Studies with inactivated influenza vaccines purified by zonal centrifugation. 1. Adverse reactions and serological responses. Bull WHO 1969; 41: 525-30

9 Schoenbaum SC, Mostow SR, Dowdle WR, Coleman MT, Kaye HS. Studies with inactivated vaccines purified by zonal centrifugation. 2 Efficacy. Bull WHO 1969; 41: 531-35

10 McElhaney JE, Meneilly GS, Lechelt KE, Beattie BL, Bleakly RC. Antibody response to whole-virus and split-virus influenza vaccines in succesful ageing. Vaccine 1993; 11: 1055-60

11 Stuart WH, Dull HB, Newton LH, MCQueen JL, Schiff ER. Evaluation of monovalent influenza vaccine in a retirement community during the epidemic of 1965-1966. JAMA 1969; 209: 232-38

12 Alling DW, Blackwelder WC, Stuart-Harris $\mathrm{CH}$. A study of excess, mortality during influenza epidemics in the United States, 1968-1976. Am J Epidemiol 1981; 113: 30-43

13 Barker WH, Mullooly JP. Pneumonia and influenza deaths during epidemics. Implications for prevention. Arch Intem Med 1982; 142: 85-99

14 Barker WH, Mullooly JP. Influenza vaccination of elderly persons, reduction in pneumonia and influenza hospitalization and deaths. JAMA 1980; 244: 2547-49

15 Barker WH, Mullooly JP. Impact of epidemic type A influenza in a defined adult population. AM J Epidemiol 1980; 112: 798-811

16 Glezen WP. Prevention of influenza-related morbidity and mortality. Arch Intern Med 1982; 142: 25-27

17 Keren G, Segev S, Morag A, Zakay-Rones Z, Barzilai A, Rubinstein A. Failure of influenza vaccination in the aged. J Med Virol 1988; 25: 85-89

18 Patriarca PA, Weber JA, Parker RA, Hall WN, Kendal AP, Bregman DJ, Schonberger LB. Efficacy of influenza vaccine in nursing homes, reduction in illness and complications, during an influenza $A$ (H3N2) epidemic. JAMA 1985; 253: 1136-39

19 Strassburg MA, Greenland S, Sorvillo FJ, Lieb LE, Habel LA. Influenza in the elderly: report of an outbreak and a review of vaccine effectiveness reports. Vaccine $1986 ; 4: 38-44$

20 Sprenger MJW. The impact of influenza: an epidemiological study of morbidity, direct mortality and telated mortality [Thesis]. Rotterdam: Erasmus Universiteit, 1990

21 Gross PA, Quinnan GV, Weksler ME, Gaerlan PF, Denning CR. Immunization of elderly people with high doses of influenza vaccine. J Am Geriatr Soc 1988; 36: 209-12

22 Beyer WEP, Palache AM, Baljet M, Masurel N. Antibody induction by influenza vaccines in the elderly: a review of the literature. Vaccine $1989 ; 7: 385-94$

23 Berlin BS, MCQueen JL, Minuse E, Davenport FM. A method for increasing the sensitivity of the haemagglutination-inhibition test with equine influenza virus. Virology $1963 ; 21: 665-67$

24 Voth DW, Feldman HA, Steinschneider A. Comparative responses of elderly persons to aqueous and depot influenza vaccines. Arch Environ Health 1966; 13: 576-85

25 Hobson D, Baker FA, Curry RL. Effects of influenza vaccines in stimulating antibody in volunteers with prior immunity. Lancet 1973; ii: 155-56

26 Pyhälä $R$, Kleemola $M$. The value of complement fixation and haemagglutination inhibition tests in the diagnosis of influenza A. Acta Virol 1976; 20: 66-69

27 Hoskins TW, Davies JR, Smith AJ, Miller CL, Allchin A. Assessment of inactivated influenza-A vaccine after three outbreaks of influenza $A$ at Christ's hospital. Lancet 1979; i: $33-35$

28 Palache AM. Influenza subunit vaccine- ten years experience. Eur J Clin Research 1992; 3: 117-38 


\section{HOOFDSTUK 11}

\section{DE EFFECTIVITEIT VAN INFLUENZAVACCINATIE BIJ OUDEREN:}

een gerandomiseerde, dubbelblinde, placebo-gecontroleerde studie

Th.M.E. Govaert, C.T.M.C.N. Thijs, M.J.W. Sprenger, G.J. Dinant, N. Masurel, J.A. Knottnerus

aangeboden 


\section{SAMENVATTING}

Doel. Het bepalen van de effectiviteit van influenzavaccinatie bij ouderen. Opzet. Gerandomiseerde, dubbelblinde, placebo-gecontroleerde studie.

Methode. Bij 1838 personen in de leeftijd van 60 jaar en ouder werd influenzavaccin of placebo toegediend. Voorafgaand aan de vaccinatie (S1), 3 weken later (S2), en aan het eind van de onderzoekperiode (S3) werd van alle deelnemers veneus bloed afgenomen. Een minimaal 4-voudige titerstijging van antilichamen en een titer $\geq 38$ van S3 ten opzichte van S2 werd bewijzend geacht voor de diagnose influenza. Tijdens de onderzoekperiode registreerden de huisartsen de symptomen van alle patiënten met klachten van griep. De deelnemers werd gevraagd een vragenlijst in te vullen indien ze meenden griep te hebben gehad en deze lijsten na week 10 en week 23 van de onderzoekperiode in te leveren.

Resultaten. Influenzavaccinatie bij ouderen geeft een reductie van morbiditeit van ongeveer $50 \%$ bij serologisch bewezen influenza. Indien de diagnose op klinische gronden wordt gesteld is de reductie minder ( $47 \%$ tot $17 \%$ ). Van de 121 patiënten met serologisch bewezen influenza bleken slechts 54 patiënten symptomen te vertonen. Kennelijk kan een bepaalde hoogte van de antilichaamtiter toch beschermen tegen de klinische manifestatie van serologisch aangetoonde influenza.

Conclusie De effectiviteit van vaccinatie wordt onderschat indien de diagnose influenza op klinische gronden wordt gesteld. Bij de klinische gestelde diagnose influenza zal de effectiviteit van vaccinatie een reductie van $50 \%$ benaderen.

Sleutelwoorden: influenzavaccinatie, effectiviteit, ouderen, risicopatiënten, antilichaamtiter, gerandomiseerd onderzoek. 


\section{INLEIDING}

In 1847 werd door William Farr al gesproken over een "oversterfte" ten gevolge van influenza (1). In 1933 werd aangetoond dat een virus het oorzakelijke agens is van influenza (2). $\mathrm{Na}$ de ontdekking hiervan werd al snel getracht een werkzaam vaccin te ontwikkelen (3). In de jaren veertig-vijftig werden de eerste resultaten gepubliceerd van grote veldstudies naar de effectiviteit van influenzavaccinaties (4-6). Influenzavaccinatie bleek een beschermend effect te hebben van $40-70 \%$. Maar niet alle studies lieten positieve resultaten zien $(7,8)$. De veldstudies in de veertiger en vijftiger jaren werden gedaan bij jonge gezonde vrijwilligers. Aangezien $95 \%$ der sterfte ten gevolge van influenza plaatsvindt bij mensen boven de 60 jaar, is het belangrijk te weten hoe effectief vaccinatie bij de doelgroep ouderen is (9). Ouderen zouden een minder goed functionerend irnmuunsysteem hebben $(10,11)$. Conclusies ten aanzien van vaccinatie bij jongeren gelden daarom niet a priori voor ouderen. In verschillende studies werd geconstateerd dat vaccinatie bij ouderen een duidelijke afname van complicaties (tot $72 \%$ ) en sterfte (tot $87 \%$ ) tot resultaat had (12-15). Dit waren echter voornamelijk retrospectieve studies. Er zijn slechts enkele prospectieve studies bij ouderen verricht (16-18). Een gerandomiseerde, dubbelblinde, placebo-gecontroleerde studie bij ouderen werd door ons niet gevonden.

Wij waren in de gelegenheid een gerandomiseerde, dubbelblinde, placebo-gecontroleerde studie naar de effectiviteit van influenzavaccinatie te verrichten in een populatie van oudere mensen. Hierbij werd de volgende vraag bestudeerd:

* Voorkómt influenzavaccinatie bij ouderen het krijgen van influenza of een influenzaachtige ziekte en zo ja, in welke mate?

\section{METHODE}

\section{Patiënten}

Aan het onderzoek, uitgevoerd in het seizoen 1991-'92, namen 34 huisartsen uit 15 huisartspraktijken deel. De totale populatie van deze praktijken bedroeg 68.988 patiënten. Uitgesloten van het onderzoek werden patiënten die door de huisarts geacht werden te behoren tot een risicogroep volgens het advies van de Gezondheidsraad (19), alsmede patiënten die verbleven in verzorgings- en verpleegtehuizen. Van de resterende patiënten werden alle personen van 60 jaar en ouder uitgenodigd voor deelname aan het onderzoek. Van de 9907 uitgenodigde personen stemden $1838(18,6 \%)$ in met deelname: 869 mannen $(47,3 \%)$ en 969 vrouwen $(52,7 \%)$. De gemiddelde leeftijd was 67 jaar (SID 6; mediaan 66) en de range: liep van 60 tot 91 jaar. Over de samenstelling van de non-respons groep zijn geen nadere gegevens beschikbaar. Velen antwoordden niet of vulden het antwoordformulier in zonder toelichting op hun weigering. Uit de resterende informatie en uit telefonische toelichtingen kon worden geconcludeerd dat de drie belangrijkste redenen voor weigering waren: angst: voor de injectie, angst voor de bloedafname en de gebondenheid in tijd gedurende de periode van het onderzoek. Tien procent van de deelnemers gaf aan in 1989 en 1990 te zijn gevaccineerd tegen influenza. Zevenentwintig procent van de deelnemers bleek alsnog cardiologische, pulmonale of stofwisselings problematiek te hebben. Deze was naar het oordeel van de eigen huisarts echter niet van dien aard dat vaccinatie was aangewezen. De deelnemende huisartsen bleken het begrip risicopatiënt verschillend te interpreteren. Ook. was het vaccinatiebeleid van de artsen niet identiek. Sornmigen riepen hun patiènten op, anderen lieten het initiatief over aan de patiënt. Om het effect van vaccinatie bij patiënten met een mogelijk verhoogd risico zo goed mogelijk te beoordelen, werden de deelnemers ingedeeld in de volgende strata: hartaandoeningen, longaandoeningen, diabetes mellitus en overige aandoeningen of gezonde deelnemers. 


\section{Interventie}

Als vaccin werd gebruikt het gezuiverd split-vaccin, geproduceerd door Evans Medical Ltd, Langhurst, Horsham, England. Dit vaccin was, evenals de andere in Nederland verkrijgbare griepvaccins, samengesteld volgens de richtlijnen van de World Health Organisation en de Gezondheidsraad. Elke dosis bevatte: A/Singapore/6/86 (H1N1), A/Beijing/353/89 (H3N2), $\mathrm{B} /$ Panama/45/90 en $\mathrm{B} / \mathrm{Beijing} / 1 / 87$, allen equivalent met 15 microgram hemagglutinine. Als placebo werd fysiologisch zout gebruikt.

Tussen 1 en 15 november 1991 werd van alle deelnemers, voorafgaande aan de injectie met vaccin of placebo, 9 milliliter veneus bloed afgenomen (S1). Het vaccin of placebo werd toegediend volgens een gestratificeerd randomisatieschema. Er werden vier strata geformeerd volgens de bovengenoemde categorieën van aandoeningen. Drie weken later werd een tweede monster afgenomen (S2). Een derde monster (S3) werd vijf maanden na S1 afgenomen (figuur 11.1). De sera van deze bloedmonsters werden bij $-20^{\circ} \mathrm{Celsius}$ bewaard en na afloop van de studieperiode voor verdere analyse vervoerd naar het Nationaal Influenza Centrum te Rotterdam. Ieder serum was voorzien van een uniek nummer, gekoppeld aan de patiënt.

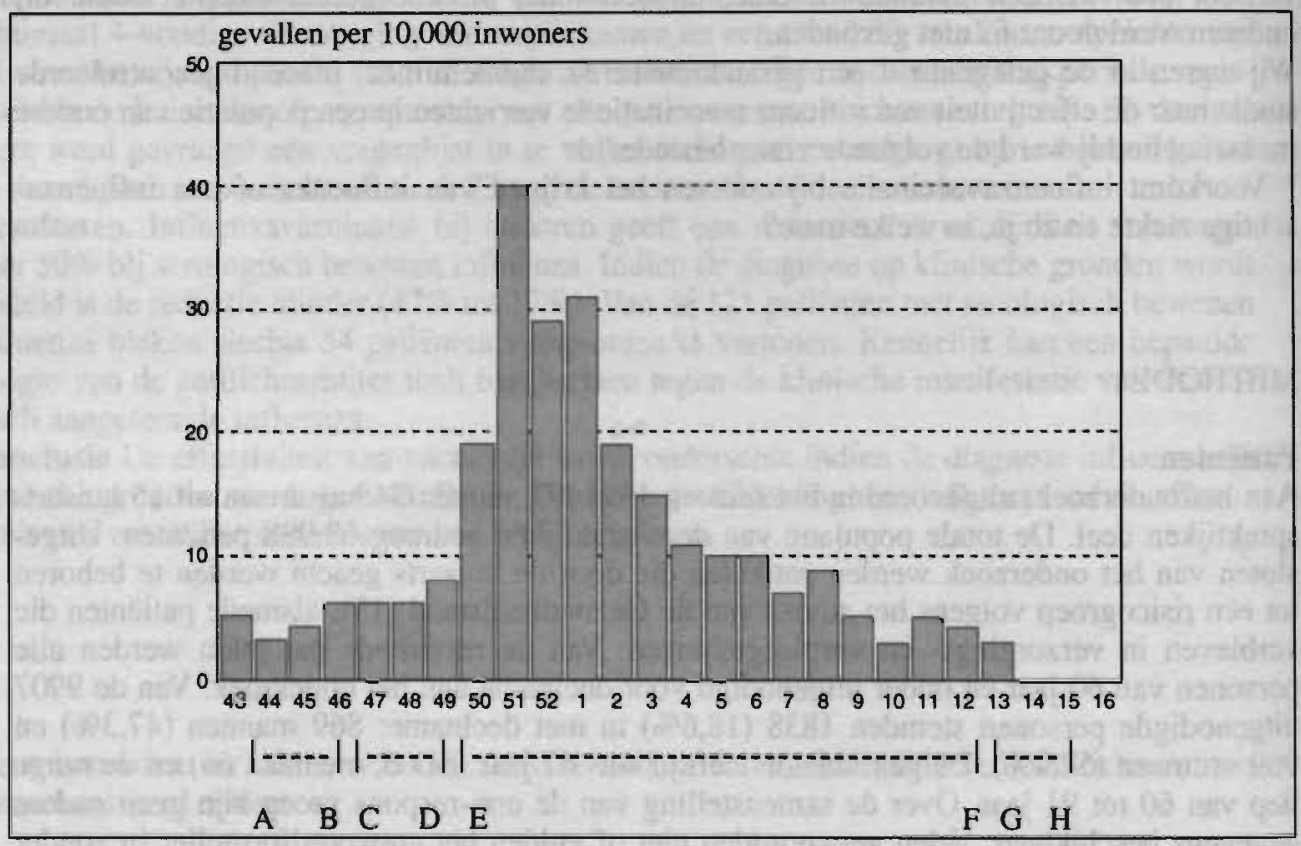

Figuur 11.1 Tijdbalk waarop de weekincidentie van influenza of influenza-achtige ziekten gedurende de onderzoekperiode (Bron: NIVEL), de periode van vaccinatie (A-B), de periodes van bloedafnames (A-B: S1; C-D: S2; G-H:S3 en E-F: S4 en S5) en de onderzoekperiode $(A-H)$ wordt weergegeven.

\section{Registratie influenza en influenza-achtige ziekten}

Aan de deelnemende huisartsen werd gevraagd gedurende de onderzoekperiode van de door hen geconstateerde grieppatiënten de relevante symptomen op een voorgedrukt formulier te registreren. Tijdens dit contact en drie weken later werd zo mogelijk ook een bloedmonster afgenomen (S4 en S5) om een tussentijdse titerstijging van antilichamen tegen influenza te kunnen objectiveren. Deze sera werden op dezelfde manier behandeld als de bloedmonsters S1,S2 en S3. 
Aan de deelnemers werd gevraagd aan het einde van de eerste (1 november 1991 tot 1 januari 1992 en tweede (1 januari 1992 tot 15 april 1992) observatieperiode (figuur 11.1) een enquête in te vullen met onder andere vragen betreffende het eventueel doorgemaakt hebben van een griepepisode en de symptomen die zich hierbij voordeden. Ook tussentijds konden de deelnemers een vragenlijst opsturen indien zij meenden griep te hebben.

\section{Laboratorium bepalingen}

De bepaling van de antilichaamtiters in de sera werd gedaan met behulp van de hemagglutinatie remmingstest. Influenza virusstammen werden gekweekt in 12 dagen oude geëmbryoneerde kippeëieren. Voor de titraties werden de stammen van of analoog aan het vaccin gebruikt. Wegens de zwakke werking van de influenza B virussen werden de met deze stam geïnfecteerde eieren behandeld met ether (20). De aldus verkregen vloeibare fase werd gebruikt voor de serologische tests. De antilichaamtiters van de monsters werden door twee analistes onafhankelijk van elkaar, tegelijkertijd, volgens standaardmethoden bepaald (21). De titers werden uitgedrukt als de omgekeerde waarden van de verdunning waarbij $50 \%$ hemagglutinatie remming plaatsvond na toevoeging van 3 eenheden hemagglutinine van het antigeen.

\section{Diagnostische criteria}

Van de door beide analistes in duplo bepaalde serumtiters werd de gemiddelde logaritmische titerwaarde per serum berekend. Voor titers lager dan 9 werd het getal 5 gebruikt.

Indien reeds vóór vaccinatie een hoge titer van antilichamen aanwezig is, kan dit de titerhoogte van antilichamen na vaccinatie beïnvloeden $(22,23)$. Daarom werd met behulp van bivariate regressie-analyse de invloed van de logaritmische titer van S1 op S2 nagegaan. Het bleek dat de logaritmische titer van S2 positief gecorreleerd was aan die van S1. Hiervoor werd gecorrigeerd. De gebruikte formule was als volgt:

$S 2$ corr $1=S 2-C(S 1-\log 10)$ waarin:

$\mathrm{S} 2$ corr 1 = de voor $\$ 1$ gecorrigeerde titer $S 2$,

$\mathrm{C}=$ regressiecoëfficient van het bivariate regressiemodel

S1 en S2 de logaritmen van de respectievelijke titers zijn.

Een titer $\geq 38$ en een viervoudige titerstijging in S3 ten opzichte van de voor S1 gecorrigeerde S2 werd bewijzend geacht voor het doorgemaakt hebben van influenza. Op dezelfde wijze werd nagegaan of in S5 ten opzichte van S4 een viervoudige titerstijging had plaatsgevonden (24). Een antilichaamtiter van $\geq 100$ voor A-stammen en $\geq 200$ voor B-stammen werd beschouwd als een beschermende titer $(21,25)$.

De criteria volgens welke door de peilstations in Nederland en de International Classification of Health Problems in Primary Care (ICHPPC-2-defined) de diagnose influenzaachtige ziekte (IAZ) wordt gesteld, werden gebruikt voor het evalueren van de door de deelnemers ingevulde enquêtelijsten (26-28) (tabel 11.1).

Aan de huisartsen werd gevraagd de criteria van de ICHPPC-2-defined toe te passen bij patiënten die zich bij hen presenteerden met verschijnselen van griep. Echter hun eigen oordeel prevaleerde bij het stellen van de klinische diagnose influenza of influenza-achtig ziekte.

\section{Data analyse}

De effectiviteit van vaccinatie tegen influenza werd weergegeven als een relatief risico (RR) en getoetst met behulp van de Chi-kwadraat. De betrouwbaarheidsintervallen (BI) werden berekend volgens de methode van Rothman (29).

In een logistisch regressiemodel werd nagegaan of het effect van vaccinatie werd beïnvloed door leeftijd, geslacht, eerdere influenzavaccinatie en het behoren tot een potentiële risicogroep (evaluatie van de interactie van deze variabelen met het al of niet gevaccineerd zijn; alpha $=0,05$; likelihood ratio; Chi-kwadraattoets) (30). 
De analyses werden verricht op een VAX-mainframe computer, met behulp van het programma BMDP, versie 1990.

\section{Goedkeuring medisch ethische commissie}

Het protocol werd goedgekeurd door de medisch ethische-commissie van de Rijksuniversiteit Limburg en het Academisch Ziekenhuis Maastricht. Door alle deelnemers werd een "informed consent" ondertekend.

\begin{tabular}{|c|c|}
\hline Tabel 11.1 & $\begin{array}{l}\text { Criteria voor het stellen van de diagnose influenza en } \\
\text { influenza-achtige ziekten. }\end{array}$ \\
\hline $\begin{array}{l}\text { Volgens de } \\
\text { PEILSTATIONS }\end{array}$ & \\
\hline (26): & $\begin{array}{l}1 \text { Een acuut begin, dus hoogstens een prodromaal stadium van drie } \\
\text { tot vier dagen (inclusief preëxistente luchtweginfectie op een niet } \\
\text { ziekmakend niveau) en } \\
2 \text { de infectie moet gepaard gaan met een temperatuursverhoging van } \\
\text { tenminste } 38^{\circ} \mathrm{C} \text {, rectaal en } \\
3 \text { tenminste één van de volgende symptomen moet aanwezig zijn : } \\
\text { hoest, coryza, rauwe keel, frontale hoofdpijn, retrosternale pijn, } \\
\text { myalgieën. }\end{array}$ \\
\hline $\begin{array}{l}\text { Volgens de } \\
\text { ICHPPC-2-defined } \\
\text { (27): }\end{array}$ & $\begin{array}{l}\text { Voor het stellen van de diagnose moet voldaan zijn aan tenminste } \\
\text { een van de drie volgende criteria: } \\
\text { a viruskweek of serologische bevestiging, } \\
\text { b een influenza epidemie en vier van de symptomen, } \\
\text { vermeld onder c } \\
\text { c zes van de volgende symptomen: } \\
\text { * plotseling begin } \\
\text { * hoesten } \\
\text { * koude rillingen } \\
\text { * koorts } \\
\text { * algehele malaise } \\
\text { * hoofdpijn } \\
\text { * myalgieën } \\
\text { * rode keel of rhinitis } \\
\text { * contact met influenza }\end{array}$ \\
\hline
\end{tabular}

\section{RESULTATEN}

De samenstelling van de onderzoekpopulatie wordt getoond in tabel 11.2. De vaccin- en placebogroep waren goed vergelijkbaar qua leeftijd, geslacht, potentiële risicostatus, het al of niet eerder gevaccineerd zijn in 1989 en 1990, en de beschermende antilichaamtiter vóór vaccinatie. Van 47 deelnemers uit de onderzoekpopulatie $(n=1838)$ waren de serologische gegevens niet compleet, gedeeltelijk door uitval der deelnemers, gedeeltelijk door ontbrekende bloedmonsters (tabel 11.3). Morbiditeit en mortaliteit van de uitvallers vond niet plaats in aansluiting op symptomen die op influenza leken. Deelnemers met incomplete bloedmonsters werden voor zover mogelijk in de analyses meegenomen. 
Tabel 11.2 Samenstelling onderzoekpopulatie $(\mathrm{n}=1838)$.

\begin{tabular}{|c|c|c|c|c|}
\hline \multirow[t]{2}{*}{ Subgroepen } & \multicolumn{2}{|c|}{ Vaccin $(n=927)$} & \multicolumn{2}{|c|}{ Placebo $(n=911)$} \\
\hline & $\mathbf{n}$ & $\%$ & $\mathrm{n}$ & $\%$ \\
\hline \multicolumn{5}{|l|}{ Potentiële risicostatus } \\
\hline Hartaandoeningen & 125 & 13,5 & 124 & 13,6 \\
\hline Longaandoeningen & 105 & 11,3 & 95 & 10,4 \\
\hline Diabetes mellitus & 21 & 2,3 & 20 & 2,2 \\
\hline Rest & 676 & 72,9 & 672 & 73,8 \\
\hline Totaal & 927 & 100 & 911 & 100 \\
\hline \multicolumn{5}{|l|}{ Geslacht } \\
\hline Man & 420 & 45,3 & 449 & 49,3 \\
\hline Vrouw & 507 & 54,7 & 462 & 50,7 \\
\hline Totaal & 927 & 100 & 911 & 100 \\
\hline \multicolumn{5}{|l|}{ Leeftijd (in jaren) } \\
\hline $60-64$ & 368 & 39,7 & 396 & 43,5 \\
\hline $65-69$ & 281 & 30,3 & 249 & 27,3 \\
\hline $70-74$ & 176 & 19,0 & 177 & 19,4 \\
\hline $75-79$ & 66 & 7,1 & 61 & 6,7 \\
\hline $80-84$ & 29 & 3,1 & 19 & 2,1 \\
\hline $85-91$ & 7 & 0,8 & 9 & 1,0 \\
\hline Totaal & 927 & 100 & 911 & 100 \\
\hline \multicolumn{5}{|l|}{ Eerder gevaccineerd } \\
\hline Ja & 118 & 12,7 & 120 & 13,2 \\
\hline Nee & 809 & 87,3 & 791 & 86,8 \\
\hline Totaal & 927 & 100 & 911 & 100 \\
\hline \multicolumn{5}{|c|}{ Beschermende titer in S1 tegen } \\
\hline A/Singapore/6/86 (H1N1) & 29 & 3,1 & 23 & 2,5 \\
\hline A/Beijing/353/89 (H3N2) & 21 & 2,3 & 28 & 3,1 \\
\hline B/Panama/45/90 & 73 & 7,9 & 60 & 6,6 \\
\hline B/Beijing/1/87 & 95 & 10,3 & 88 & 9.7 \\
\hline
\end{tabular}

In tabel 11.4 wordt de effectiviteit van vaccinatie getoond. Serologisch influenza en influenza-achtige ziekten volgens de huisarts en de peilstations kwamen statistisch significant minder vaak voor in de vaccingroep dan in de placebogroep. Bij patiënten met influenzaachtige ziekten volgens de ICHPPC-2-defined-criteria was dit verschil geringer en statistisch niet significant. Indien we echter het effect van vaccinatie beoordeelden in de periode van week 49 in 1991 tot week 6 in 1992, zijnde de periode met een epidemische verheffing (figuur 11.1) was er een gunstiger effect van vaccinatie bij influenza-achtige ziekten volgens de ICHPPC-2-defined-criteria ( $R R=0,74 ; B I: 0,24-1,00 ; p=0,62$ ). In diezelfde periode was het relatieve risico bij serologisch vastgestelde influenza met klinische symptomen 0,39 (BI:0,22-0,68), bij influenza-achtige ziekten volgens de huisartsen 0,40 (BI:0,190,87 ) en bij influenza-achtige ziekten volgens de criteria van de peilstations 0,41 (BI:0,82$0,61)$.

Tabel 11.5 toont de resultaten na stratificatie voor risico-status, geslacht, leeftijd en vaccina- 
Tabel 11.3 Aantal uitvallers na randomisatie.

\begin{tabular}{lcc}
\hline Reden & $\begin{array}{r}\text { Vaccin } \\
\mathrm{n}\end{array}$ & $\begin{array}{r}\text { Placebo } \\
\mathrm{n}\end{array}$ \\
\hline $\begin{array}{l}\text { Gestorven } \quad \text { (8x hartaanval, 1x ruptuur aneurysma aortae) } \\
\text { Intercurrente ziekte }\end{array} \quad$ (cerebro vasculair accident) & 6 & 3 \\
Geen interesse meer & 1 & 2 \\
Vakantie & 5 & 3 \\
Reeds vaccin gespoten door huisarts & 0 & 1 \\
Ontbrekende laboratorium gegevens & 1 & 0 \\
\hline Totaal & 12 & 13 \\
\hline
\end{tabular}

tiestatus (wel of niet eerder gevaccineerd). De incidentie van influenza of influenza-achtige ziekten was voor de diverse subgroepen vergelijkbaar met de incidentie voor de gehele onderzoekpopulatie (tabel 11.4 en 11.5). Er was steeds een duidelijk verschil tussen het voorkomen van influenza of influenza-achtige ziekten bij gevaccineerden ten opzichte van niet gevaccineerden, ten gunste van de eersten, echter met uitzondering van 70-plussers. In deze leeftijdsgroep werd weinig verschil gevonden in het krijgen van influenza of influenza-achtige ziekten tussen gevaccineerden en niet gevaccineerden. De betrouwbaarheidsintervallen van de verschillende relatieve risico's in deze leeftijdscategorie bedroegen 0,39 -

Tabel 11.4 Effectiviteit van vaccinatie bij deelnemers met influenza of influenzaachtige ziekten, gediagnostiseerd volgens verschillende criteria.

\begin{tabular}{|c|c|c|c|c|c|c|c|c|}
\hline & \multicolumn{8}{|c|}{ Influenza of influenza-achtige ziekten volgens } \\
\hline & \multicolumn{2}{|c|}{ Serologie } & \multicolumn{2}{|c|}{ Huisarts } & \multicolumn{2}{|c|}{ Peilstations } & \multicolumn{2}{|c|}{ ICHPPC-2-defined } \\
\hline & vac & plac & vac & plac & vac & plac & vac & plac \\
\hline $\begin{array}{l}\mathrm{n} \\
\%\end{array}$ & $\begin{array}{r}41 \\
4,5\end{array}$ & $\begin{array}{r}80 \\
9,0\end{array}$ & $\begin{array}{r}17 \\
1,8\end{array}$ & $\begin{array}{l}31 \\
3,4\end{array}$ & $\begin{array}{r}62 \\
6,7\end{array}$ & $\begin{array}{r}89 \\
9,8\end{array}$ & $\begin{array}{l}108 \\
11,8\end{array}$ & $\begin{array}{r}129 \\
14,2\end{array}$ \\
\hline $\begin{array}{l}\text { Totaal } \\
\text { uitvallers }\end{array}$ & $\begin{array}{r}902 \\
25\end{array}$ & $\begin{array}{r}889 \\
22\end{array}$ & $\begin{array}{r}927 \\
0\end{array}$ & $\begin{array}{r}911 \\
0\end{array}$ & $\begin{array}{r}919 \\
8\end{array}$ & $\begin{array}{r}909 \\
2\end{array}$ & $\begin{array}{r}919 \\
8\end{array}$ & $\begin{array}{r}909 \\
2\end{array}$ \\
\hline p-waarde & \multicolumn{2}{|c|}{$<0,001$} & \multicolumn{2}{|c|}{0,04} & \multicolumn{2}{|c|}{0,02} & \multicolumn{2}{|c|}{0,12} \\
\hline RR & \multicolumn{2}{|c|}{0,50} & \multicolumn{2}{|c|}{0,53} & \multicolumn{2}{|c|}{0,69} & \multicolumn{2}{|c|}{0.83} \\
\hline $95 \% \mathrm{BI}$ & \multicolumn{2}{|c|}{$0,35-0,61$} & \multicolumn{2}{|c|}{$0,39-0,73$} & \multicolumn{2}{|c|}{$0,50-0,87$} & \multicolumn{2}{|c|}{$0,65-1,05$} \\
\hline
\end{tabular}

$\mathrm{n}$ : aantal gevallen van influenza of influenza-achtige ziekten

RR: relatief risico

$\mathrm{BI}$ : betrouwbaarheidsinterval 


\section{Tabel 11.5 Effectiviteit van influenzavaccinatie gestratificeerd naar risicostatus, geslacht,leeftijd en vaccinatiestatus.}

Subgroep * Influenza of influenza-achtige ziekten volgens

\begin{tabular}{|c|c|c|c|c|c|c|c|c|c|}
\hline & & \multicolumn{2}{|c|}{$\begin{array}{l}\text { Serologie } \\
(n=121)\end{array}$} & \multicolumn{2}{|c|}{$\begin{array}{r}\text { Huisarts } \\
(n=48)\end{array}$} & \multicolumn{2}{|c|}{$\begin{array}{l}\text { Peilstation } \\
(\mathrm{n}=151)\end{array}$} & \multicolumn{2}{|c|}{$\begin{array}{l}\text { ICHPPC-2-defined } \\
(\mathrm{n}=237)\end{array}$} \\
\hline & & vac & plac & vac & plac & vac & plac & vac & plac \\
\hline $\begin{array}{l}\text { Risico- } \\
\text { patiënten }\end{array}$ & $\begin{array}{r}\text { n } \\
\% \\
\text { tot. } \\
\text { RR }\end{array}$ & $\begin{array}{r}9 \\
3,7 \\
242 \\
0\end{array}$ & $\begin{array}{r}21 \\
9,0 \\
234 \\
1\end{array}$ & $\begin{array}{r}5 \\
2,0 \\
251 \\
0\end{array}$ & $\begin{array}{r}11 \\
5,0 \\
239 \\
3\end{array}$ & $\begin{array}{r}21 \\
8,4 \\
250\end{array}$ & $\begin{array}{r}23 \\
9,7 \\
238 \\
7\end{array}$ & $\begin{array}{r}35 \\
14 \\
250 \\
0\end{array}$ & $\begin{array}{r}39 \\
16,4 \\
238 \\
5\end{array}$ \\
\hline $\begin{array}{l}\text { Overigen/ } \\
\text { gezonden }\end{array}$ & $\begin{array}{r}\text { n } \\
\% \\
\text { tot. } \\
\text { RR }\end{array}$ & $\begin{array}{r}32 \\
4,8 \\
660\end{array}$ & $\begin{array}{r}59 \\
9,0 \\
665 \\
5\end{array}$ & $\begin{array}{r}12 \\
1,8 \\
676\end{array}$ & $\begin{array}{r}20 \\
3,0 \\
672 \\
0\end{array}$ & $\begin{array}{r}41 \\
6,1 \\
669\end{array}$ & $\begin{array}{r}66 \\
9,8 \\
671 \\
2^{671}\end{array}$ & $\begin{array}{r}73 \\
10,9 \\
669 \\
0\end{array}$ & $\begin{array}{r}90 \\
13,4 \\
671 \\
1\end{array}$ \\
\hline Mannen & $\begin{array}{r}\text { n } \\
\% \\
\text { tot. } \\
\text { RR }\end{array}$ & $\begin{array}{r}12 \\
2,9 \\
407\end{array}$ & $\begin{array}{r}41 \\
9,3 \\
439 \\
\end{array}$ & $\begin{array}{r}5 \\
1,2 \\
420\end{array}$ & $\begin{array}{r}15 \\
3,3 \\
449 \\
6\end{array}$ & $\begin{array}{r}24 \\
5,7 \\
418\end{array}$ & $\begin{array}{r}33 \\
7,4 \\
448 \\
18\end{array}$ & $\begin{array}{r}39 \\
9,3 \\
418 \\
0\end{array}$ & $\begin{array}{r}46 \\
10,3 \\
448 \\
1\end{array}$ \\
\hline Vrouwen & $\begin{array}{r}\text { n } \\
\% \\
\text { tot. } \\
\text { RR }\end{array}$ & $\begin{array}{r}29 \\
5,8 \\
495\end{array}$ & $\begin{array}{r}39 \\
8,7 \\
450 \\
8\end{array}$ & $\begin{array}{r}12 \\
2,4 \\
507\end{array}$ & $\begin{array}{r}16 \\
3,5 \\
462 \\
8\end{array}$ & $\begin{array}{r}38 \\
7,6 \\
501\end{array}$ & $\begin{array}{r}56 \\
12,1 \\
461 \\
2^{461}\end{array}$ & $\begin{array}{r}69 \\
13,8 \\
501 \\
0\end{array}$ & $\begin{array}{r}83 \\
17,8 \\
461 \\
6\end{array}$ \\
\hline $\begin{array}{l}\text { Leeftijd } \\
60-69\end{array}$ & $\begin{array}{r}\text { n } \\
\% \\
\text { tot. } \\
\text { RR }\end{array}$ & $\begin{array}{r}27 \\
4,3 \\
635 \\
0\end{array}$ & $\begin{array}{r}62 \\
9,9 \\
626\end{array}$ & $\begin{array}{r}9 \\
1,4 \\
649\end{array}$ & $\begin{array}{r}22 \\
3,4 \\
645\end{array}$ & $\begin{array}{r}47 \\
7,3 \\
644\end{array}$ & $\begin{array}{r}73 \\
11,3 \\
644\end{array}$ & $\begin{array}{r}84 \\
13,0 \\
644 \\
0\end{array}$ & $\begin{array}{r}105 \\
16,3 \\
644\end{array}$ \\
\hline$\geq 70$ & $\begin{array}{r}\text { n } \\
\% \\
\text { tot. } \\
\text { RR }\end{array}$ & $\begin{array}{r}14 \\
5,2 \\
267 \\
0\end{array}$ & $\begin{array}{r}18 \\
6,8 \\
263 \\
7\end{array}$ & $\begin{array}{r}8 \\
2,9 \\
278 \\
0\end{array}$ & $\begin{array}{r}9 \\
3,4 \\
266 \\
5\end{array}$ & $\begin{array}{r}15 \\
5,5 \\
275\end{array}$ & $\begin{array}{r}16 \\
6,0 \\
265\end{array}$ & $\begin{array}{r}24 \\
8,7 \\
275 \\
0\end{array}$ & $\begin{array}{r}24 \\
9,1 \\
265 \\
6\end{array}$ \\
\hline $\begin{array}{l}\text { Eerder ge } \\
\mathrm{Ja}\end{array}$ & $\begin{array}{r}\text { vacci } \\
\text { n } \\
\% \\
\text { tot. } \\
\text { RR }\end{array}$ & $\begin{array}{r}\text { erd } \\
1 \\
0,9 \\
117 \\
0\end{array}$ & $\begin{array}{r}9 \\
8 \\
113 \\
1 \quad\end{array}$ & $\begin{array}{r}3 \\
2,5 \\
119\end{array}$ & $\begin{array}{r}11 \\
9,2 \\
119 \\
\end{array}$ & $\begin{array}{r}11 \\
9,3 \\
118 \\
0\end{array}$ & $\begin{array}{r}15 \\
12,6 \\
119\end{array}$ & $\begin{array}{r}16 \\
13,6 \\
118 \\
0\end{array}$ & $\begin{array}{r}23 \\
19,3 \\
119\end{array}$ \\
\hline $\mathrm{Nee}$ & $\begin{array}{r}\text { n } \\
\% \\
\text { tot. } \\
\text { RR }\end{array}$ & $\begin{array}{r}40 \\
5,1 \\
784 \\
0\end{array}$ & $\begin{array}{r}71 \\
9,1 \\
775 \\
6\end{array}$ & $\begin{array}{r}14 \\
1,7 \\
807\end{array}$ & $\begin{array}{r}20 \\
2,5 \\
791\end{array}$ & $\begin{array}{r}50 \\
6,3 \\
800\end{array}$ & $\begin{array}{r}74 \\
9,4 \\
789 \\
7\end{array}$ & $\begin{array}{r}91 \\
11,4 \\
800 \\
0\end{array}$ & $\begin{array}{r}106 \\
13,4 \\
789 \\
\end{array}$ \\
\hline
\end{tabular}

*: deelnemers met onvolledige gegevens werden niet meegerekend.

$\mathrm{n}$ : aantal gevallen van influenza of influenza-achtige ziekten

RR: relatief risico

tot.: totaal 
1,51 voor serologisch influenza; $0,33-2,17$ voor influenza-achtige ziekten volgens de huisartsen; $0,35-1,79$ volgens de criteria van de peilstations en $0,56-\mathbf{i}, 65$ volgens criteria van de ICHPPC-2-defined.

De relatieve risico's gevonden in de logistische regressie-analyse kwamen overeen met die beschreven in tabel 11.4. Er was geen statistisch significante invloed van leeftijd, geslacht, eerdere influenzavaccinatie en het behoren tot de risicopatiënten op de hoogte van het relatieve risico. Een uitzondering daarop werd gevonden bij het effect van griepvaccinatie op deelnemers die influenza of influenza-achtige ziekte hadden volgens hun huisarts; bij een toename van de leeftijd verdween het effect van vaccinatie (met leeftijd als continue variabele in het model was de $\mathrm{p}$-waarde voor deze invloed $<0,01$ ). Doordat in deze regressieanalyse tegelijkertijd werd gecorrigeerd voor de andere variabelen, kan deze invloed niet worden verklaard door bijvoorbeeld eerdere vaccinaties, welke met toename van de leeftijd vaker hebben plaatsgevonden.

\begin{tabular}{|c|c|c|c|c|c|c|}
\hline Tabel 11.6 & \multicolumn{6}{|c|}{$\begin{array}{l}\text { Verband tussen minimaal viervoudige titerstijging en beschermende } \\
\text { antilichaamtiter (BT) per stam bij deelnemers met serologisch bewezen } \\
\text { influenza. }\end{array}$} \\
\hline \multirow[t]{3}{*}{$\overline{\text { Stam }}$} & \multicolumn{3}{|c|}{ Vaccin $(n=41)$} & \multicolumn{3}{|c|}{ Placebo $(n=80)$} \\
\hline & \multirow[t]{2}{*}{$\mathrm{n}^{*}$} & \multicolumn{2}{|c|}{ BT } & \multirow[t]{2}{*}{$\mathrm{n}^{*}$} & \multicolumn{2}{|c|}{ BT } \\
\hline & & ja & nee & & ja & nee \\
\hline AS & 8 & 0 & 8 & 9 & 0 & 9 \\
\hline$A B$ & 29 & 4 & 25 & 67 & 1 & 66 \\
\hline BP & 7 & 0 & 7 & 9 & 0 & 9 \\
\hline BB & 3 & 0 & 3 & 9 & 0 & 9 \\
\hline
\end{tabular}

* Omdat bij sommige deelnemers een titerstijging werd geconstateerd tegen meerdere stammen tegelijk is het aantal gevallen met een minimaal viervoudige titerstijging (141) groter dan het aantal deelnemers (121)

AS: $\quad$ A/Singapore/6/86 (H1N1)

AB: $\quad$ A/Beijing/353/89 (H3N2)

BP: $\quad$ B/Panama/45/90

BB: $\quad$ B/Beijing/1/87

Bij de deelnemers die de voorafgaande twee jaren ook gevaccineerd waren $(n=117)$ werd bij $0.9 \%$ serologisch influenza aangetoond. Bij de deelnemers die nu voor de eerste keer gevaccineerd waren $(n=784)$ werd bij $5,1 \%$ serologisch influenza aangetoond (tabel 11.5). Dit verschil was statistisch significant $(\mathrm{p}=0,04)$. In de logistische regressie-analyse was dit verschil bijna statistisch significant $(\mathrm{p}=0,07)$.

Bij 121 deelnemers werd aan het eind van de onderzoekperiode een minimaal viervoudige titerstijging gevonden. Tabel 11.6 laat de titerstijging bij deze deelnemers zien per stam. Bij 10 deelnemers kwamen titerstijgingen voor tegen meerdere stammen; bij 7 deelnemers tegen 2 stammen, bij 2 tegen 3 en bij 3 tegen alle vier de stammen. Van de 141 bepalingen waarbij een minimaal 4-voudige titerstijging werd gevonden (dus influenza) bleek $136 \mathrm{keer}$ $(97 \%)$ geen beschermende antilichaamtiter in S2 aanwezig te zijn. De analyses van de sera van S4 en S5 leverden 15 maal een 4-voudige titerstijging op. Twee hiervan werden niet gededecteerd bij de analyses van S2 en S3. 


\section{Tabel 11.7 Relatief risico (RR) en betrouwbaarheidsintervall (BI) van gevaccineerden ten opzichte van niet gevaccineerden bij diverse combinaties van serologisch influenza en klinisch influenza.}

\begin{tabular}{llcccc}
\hline \multicolumn{2}{c}{ Influenza } & Vaccin & Placebo & RR & BI \\
klinisch* & serologisch & $(\mathrm{n}=927)$ & $(\mathrm{n}=911)$ & & \\
\hline nee & nee & 753 & 694 & - & - \\
ja & nee & 107 & 115 & 0,92 & $0,72-1,17$ \\
nee & ja & 25 & 42 & 0,59 & $0,36-0,96$ \\
ja & ja & 16 & 38 & 0,42 & $0,23-0,74$ \\
uitvallers & & 26 & 22 & - & - \\
\hline
\end{tabular}

* Klinische influenza volgens criteria van huisarts, peilstations of ICHPPC-2-defined

Van de 121 deelnemers met serologisch aangetoonde influenza hadden 67 geen klinische verschijnselen (tabel 11.7). Bij 55 van deze 67 deelnemers werd een verhoogde antilichaamtiter in S2 gevonden. Deze was echter niet zodanig hoog dat men van een beschermende titer volgens gangbare normen mocht spreken $(\geq 100$ respectievelijk $\geq 200)(21,25)$. Tevens blijkt uit deze tabel waarin voor vaccin- en placebogroep de diverse mogelijke combinaties van influenza-achtige ziekten en serologisch influenza in kaart werden gebracht, dat de diagnose influenza op klinische gronden gesteld veel ruis vertoonde en dat vaccinatie de hoogste bescherming opleverde bij het complete beeld van influenza, dus klinisch influenza, serologisch bevestigd $(R R=0,42)$.

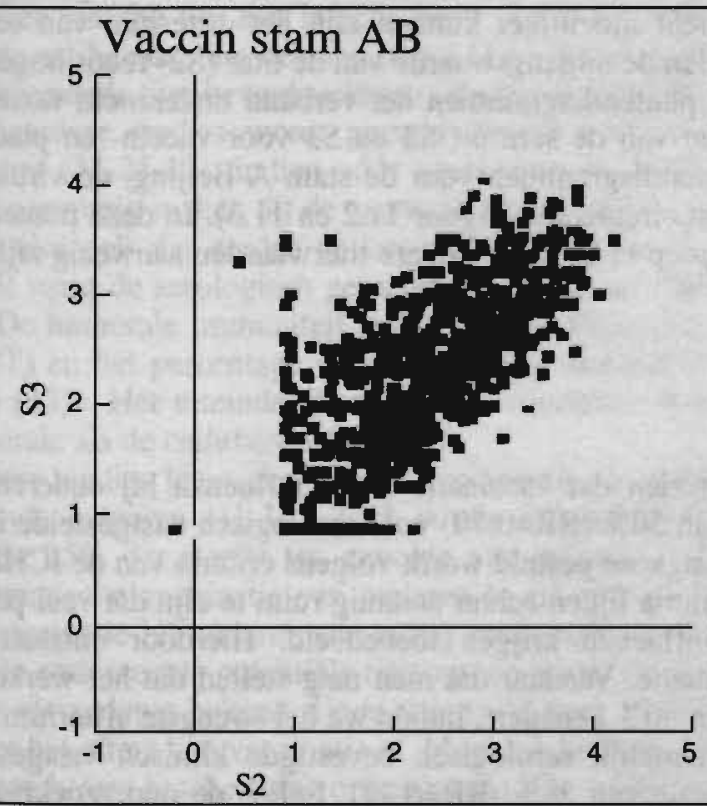

Figuur 11.2 Puntendiagram van de logaritmisch gemiddelde titers van $S 2$ en $S 3$ bij gevaccineerde deelnemers $(n=900)$ voor de stam A/Beijing. 


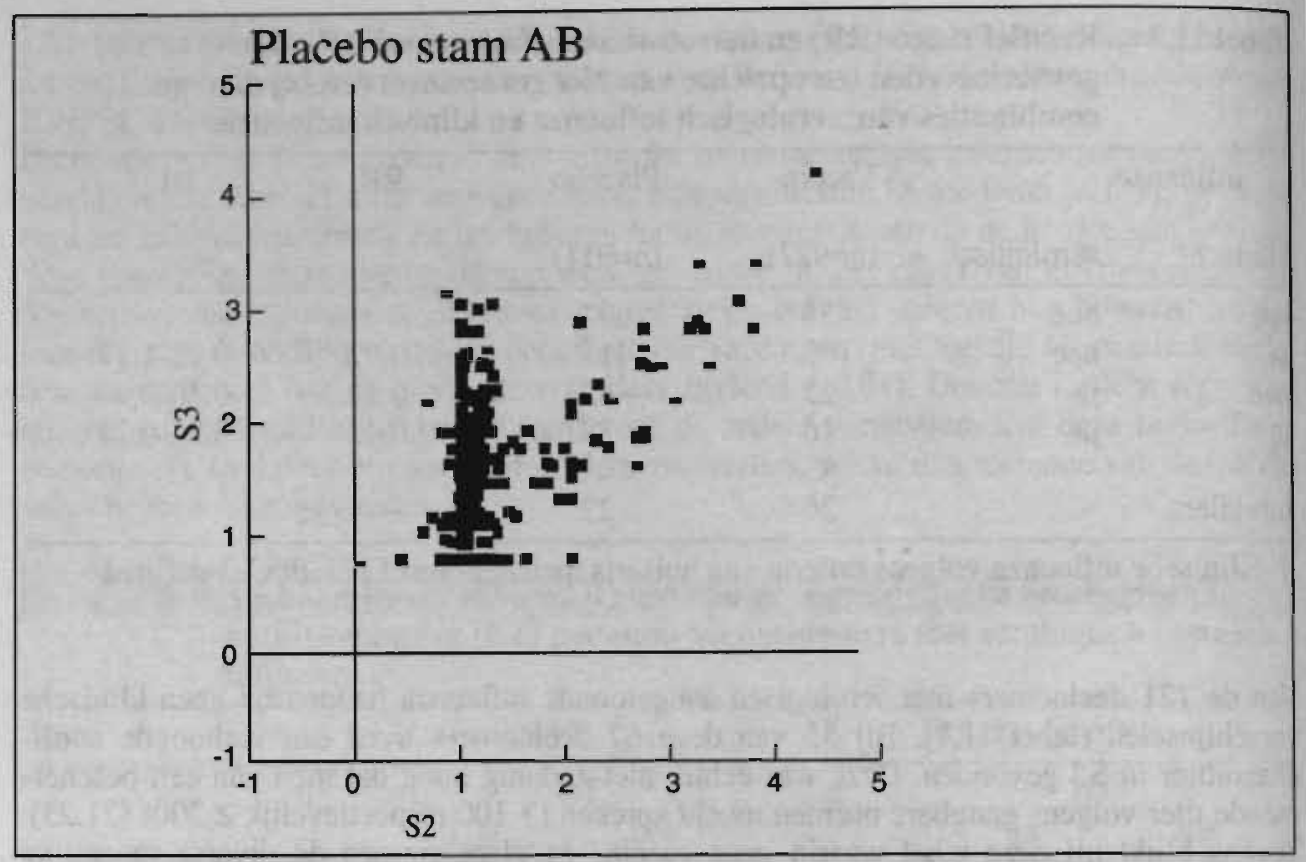

Figuur 11.3 Puntendiagram van de logaritmisch gemiddelde titers van S2 en S3 bij met placebo gevaccineerde deelnemers ( $n=887$ ) voor de stam A/Beijing.

In tegenstelling tot de klinische diagnose is de serologische diagnose niet strikt geblindeerd. Immers bij het criterium serologisch influenza werd de antilichaamtiter als gevolg van vaccinatie betrokken. Het zou wellicht moeilijker kunnen zijn het criterium van een 4 . voudige titerstijging te realiseren indien de uitgangswaarde van de titer (S2) reeds hoger ligt (18). Daarom werd met behulp van puntendiagrammen het verband onderzocht tussen de logaritmisch gemiddelde titerwaarden van de sera uit S2 en S3 voor vaccin- en placebogroep. Afgebeeld zijn alleen de puntendiagrammen voor de stam A-Beijing, de virusstam die in de onderzoekperiode het meest circuleerde (figuur 11.2 en 11.3). In deze puntendiagrammen ziet men dat in de vaccingroep in \$2 meer hogere titerwaarden aanwezig zijn dan in de placebogroep.

\section{BESCHOUWING}

De resultaten van deze studie laten zien dat vaccinatie tegen influenza bij ouderen een risicoreductie oplevert die varieert van $50 \%(R R=0,50)$ voor serologisch vastgestelde influenza tot $17 \%(R R=0,83)$ indien de diagnose gesteld wordt volgens criteria van de ICHPPC2-defined. De ICHPPC-2-defined-criteria lijken echter zodanig ruim te zijn dat veel patiënten een vals positieve diagnose influenza krijgen toebedeeld. Hierdoor ontstaat een verdunning van het effect van vaccinatie. Vandaar dat men mag stellen dat het werkelijke effect van vaccinatie een reductie van $50 \%$ benadert. Indien we het strengste criterium voor de diagnose influenza toepassen, namelijk serologisch bevestigde klinisch vastgestelde influenza, vinden we zelfs een reductie van $58 \%(\mathrm{RR}=0,42)$. Indien de onderzoekperiode naar het effect van vaccinatie wordt beperkt tot alleen de periode van epidemische verheffing van influenza, waardoor de vals positieve diagnoses worden verdrongen door de 
werkelijke influenzagevallen, is er ook bij toepassing van de ICHPPC-2-defined-criteria een duidelijk effect van vaccinatie waarneembaar, namelijk een reductie van $26 \%$ ( $R R=0,74)$. Dit illustreert tevens hoe belangrijk het is de onderzoekperiode goed te omschrijven indien men die studies met elkaar wilt vergelijken waarin de resultaten uitgedrukt worden in risicoreducties of relatieve risico's $(4,31)$.

Er bestond een duidelijke discrepantie tussen patiënten met serologisch aangetoonde influenza en influenza-achtige ziekten volgens de overige criteria. Bij 67 van de 121 deelnemers met serologisch aangetoonde influenza werden geen klinische verschijnselen gevonden. Bij 55 van deze 67 deelnemers bleek er een verhoogde antilichaamtiter ten gevolge van vaccinatie te bestaan. Hoewel deze hoogte niet zodanig was dat serologische influenza voorkomen kon worden, was de titer kennelijk voldoende in staat om klinische manifestatie van een influenza besmetting te onderdrukken. Dit werd reeds eerder vermoed (16). Op grond hiervan zou men kunnen veronderstellen dat de reductie van influenza door vaccinatie meer is dan de berekende $50 \%(\mathrm{RR}=0,50)$, namelijk $58 \%(\mathrm{RR}=42 \%)$ (tabel 11.7$)$.

De figuren 11.2 en 11.3 suggeren dat de absolute titerstijging in de vaccingroep gemiddeld hoger moet zijn dan in de placebogroep, teneinde na besmetting een minimaal 4-voudige stijging te halen (op een logaritmische schaal een toename van tenminste 0,60 ). Het is de vraag of de placebogroep hiermee in een ongunstige uitgangspositie komt, dat wil zeggen eerder het criterium 4-voudige titerstijging overstijgt. Dit zou een overschatting van het beschermend effect van vaccinatie op serologisch influenza tot gevolg kunnen hebben. Daar tegenover staat de bevinding dat bij toepassing van de klinische criteria voor griep ook een gunstig effect van vaccinatie werd gezien.

In onze studie werd voornamelijk een beschermende werking van het vaccin gevonden voor de stam A/Beijing. Door het Nationaal Influenza Centrum te Rotterdam werd gedurende het seizoen $1991-92$ in $65 \%$ der isolaten een virusstam aangetoond die een antigene structuur bezat die compatibel was met de in het vaccin aanwezige A/Beijingstam. Dit lijkt te verklaren waarom in de onderzoekpopulatie meer $\mathrm{A} / \mathrm{B}$ eijing besmettingen werden aangetoond. Een uitspraak over de beschermende werking van de andere stammen in het vaccin is gezien het gering aantal infecties met deze virusstammen niet mogelijk. Wel blijkt dat in die gevallen waarbij wel een infectie heeft plaats gevonden in $97 \%$ der gevallen geen beschermende antilichaamtiter bestond (tabel 11.6). Waarschijnlijk zullen vaccins, die een voldoende beschermende titer bewerkstelligen effectiever zijn bij het voorkómen van influenza.

In meerdere studies wordt gemeld dat de beschermingsgraad door eerdere vaccinaties afneemt $(21-25,32)$. Indien vóór vaccinatie een hoge antilichaamtiter tegen een bepaalde stam aanwezig is, kan dit de aanmaak van nieuwe antilichamen beïnvloeden. Toch blijktt in dit onderzoek dat eerder gevaccineerden minder vaak influenza krijgen. Waarschijnlijk speelt naast de serologisch gemeten humorale immuniteit ook de cellulaire immuniteit een rol. De humorale immuniteit wordt meestal uitgedrukt in de geometrisch gemiddelde titer (GMT) en het percentage mensen met een beschermende antilichaamtiter, protection rate (PR) (33). Het uiteindelijk effect van vaccinatie wordt mogelijk bepaald door zowel de humorale als de cellulaire immuniteit.

Eerdere studies laten zien dat het rendement van vaccinatie bij ouderen kleiner is dan bij gezonde jongeren (11-14). Toch is een risicoreductie van 50\% in een bevolkingsgroep waarin $95 \%$ der sterfte ten gevolge van influenza plaats vindt, meer dan acceptabel orn systematische vaccinatie van ouderen te entameren. Ook kosten-baten analyses laten zien dat vaccinatie bij ouderen een nuttig rendement oplevert (34-36). Gezien de samenstelling van de onderzochte potentiële risicogroep lijken de gevonden bevindingen toepasbaar op de reeds als zodanig bekend zijnde risicopatiënten. Naarmate de deelnemers ouder waren nam echter het effect van vaccinatie af. Mogelijk hebben ouderen tengevolge van vroegere infecties een betere bescherming opgebouwd (37). Verder was tijdens dit onderzoek de incidentie van influenza laag en was het aantal 70-plussers te klein om een invloed van de leeftijd op het effect van vacinatie redelijk betrouwbaar aan te tonen. 
Indien we de resultaten van dit onderzoek toevoegen aan de bevindingen uit eerdere studies, te weten een beschermend effect van vaccinatie op het voorkómen van influenza van $40 \%$ $70 \%$ in jongere populaties en een reductie van ernstige morbiditeit en mortaliteit bij ouderen van $70 \%$ - $80 \%$, mogen we stellen dat het nuttig effect van influenzavaccinatie voldoende onderbouwd is.

\section{LITERATUUR}

1 Langmuir AD. William Farr: founder of modern concepts of surveillance. Int J Epidemiol 1976; 5: 13-18

2 Smith W. Andrewes $\mathrm{CH}$, Laidlaw $\mathrm{CH}$. A virus obtained from influenza patiennts. Lancet 1933; i: 66-68

3 Henle W, Henle G, Stokes J. Demonstration of efficacy of vaccination against influenza type A by experimental infection of human beings. J Immunology 1943; 46: 163-75

4 Members of the commission on influenza. A clinical evaluation of vaccination against influenza. JAMA 1944; $124: 982-85$

5 Committee on clinical trials of influenza vaccine. Clinical trials of influenza vaccine. Br Med J 1953; 267: 1173-77

$6 \mathrm{Mc}$ Donald JC, Andrews BE. Diagnostic methods in an influenza vaccine trial. Br Med J 1955; 269: 1232-35

7 Committee on clinical trials of influenza vaccine. Clinical trials of influenza vaccine. Br Med J 1957; 27: 1-7

8 D'Alessio DJ, Cox PM, Dick EL. Failure of inactivated influenza vaccine to protect aged population. JAMA 1969; 210: 485-89

9 Sprenger MJW, Mulder PGH, Beyer WEP, Strik R van, Masurel N. Impact of influenza on mortality regarding age and entity of underlying disease, during the period 1967 to 1989. Int J Epidemiol 1993; 22: $333-39$

10 Keren G, Segev S, Morag A, Zakay-Rones Z, Barzilai A, Rubinstein E. Failure of influenza vaccination in the aged. J Med Virol 1988; 25: 85-89 
11 Strassburg MA, Greenland S, Sorvillo FJ, Lieb LE, Habel LA. Influenza in the elderly: report of an outbreak and a review of vaccine effectiveness reports. Vaccine 1986; 4: 38-44

12 Barker WH, Mullooly JP. Pneumonia and influenza deaths during epidemics. Implications for prevention. Arch Intern Med 1982; 142: 85-89

13 Barker WH, Mullooly JP. Influenza vaccination of elderly persons, reduction in pneumonia and influenza hospitalization and deaths. JAMA 1980; 244: 2547-49

14 Barker WH, Mullooly JP. Impact of epidemic type A influenza in a defined adult population. Am J Epidemiol 1980; 112: 798-811

15 Patriarca PA, Weber JA, Parker RA, Hall WN, Kendal AP, Bregman DJ. Efficacy of influenza vaccine in nursing homes, reduction in illness and complications during an influenza A (H3N2) epidennic. JAMA 1985; 253: 1136-39.

16 Gross PA, Quinnan GV, Rodstein M, LaMontagne JR, Kaslow RA, Saah AJ, et al. Association of influenza immunization with reduction in mortality in an elderly population, a prospective study. Arch intern Med 1988; 148 (3): 562-65

17 Stuart WH, Dull HB, Newton LH, McQueen JL, Schiffer ER. Evaluation of monovalent influenza vaccine in a retirement community during the epidemic of 1965-1966. JAMA 1969;209:232-38

18 Schoenbaum SC, Mostow SR, Dowdle WR, Coleman MT, Kaye HS. Studies with inactivated influenza vaccines perified by zonal centrifugation 2. Efficacy. Bull WHO 1969; 41: 531-35

19 Gezondheidsraad: Commissie vaccinatie tegen influenza. Vaccinatie tegen influenza: seizoen 1991-1992. Den Haag: Gezondheidsraad, 1991/15

20 Berlin BS, MCQueen JL, Minuse E, Davenport FM. A method for increasing the sensitivity of the haemagglutination-inhibition test with equine influenza virus. Virology 1963; 21: 665-67

21 Masurel N, Ophof B, Jong P de. Antibody respons to immunization with influenza AUSSR/77 (H1N1) virus in young individuals primed or unprimed for ANNew Jersey/76 (H1N1) virus. J Hyg 1981; 87: 201-09

22 Voth DW, Feldman HA, Steinschneider A. Comparative responses of elderly persons to aqueous and depot influenza vaccines. Arch Environ Health 1966; 13: 576-85

23 Hobson D, Baker FA, Curry RL. Effects of influenza vaccines in stimulating antibody in volunteers with prior immunity. Lancet 1973; ii: 155-56

24 Pyhälä R, Kleemola $M$. The value of complement fixation and haemagglutination inhibition tests in the diagnosis of influenza A. Acta Virol 1976; 20: 66-69

25 Masurel N, Laufer J. A one year study of trivalent influenza vaccines in primed and unprimed volunteers: immunogenicity, clinical reactions and protection. J Hyg 1984; 92: 263-75

26 Pel JZS. Proefonderzoek naar de frequentie en de etiologie van griepachtige ziekten in de winter 1963-1964. Huisarts Wet 1965; 8: 321-24

27 Classification Committee of WONCA. ICHPPC-2-defined. Inclusion criteria for the use of the rubrics of the International Classification of Health Problems in Primary Care. Oxford: Oxford University Press, 1983

28 Lamberts H, Wood M. International Classification of Primary Care. Oxford: Oxford University Press, 1983

29 Rothman KJ. Modern epidemiology. Boston: Little, Brown and cie, 1985: 171-73

30 Kleinbaum DG, Kupper LL, Morgenstern H. Epidemiologic research. Principles and quantitative methods. London: Lifetime Learning Publications, 1982: 477-82

31 Thijs $C$, Knipschild $P$, Leffers $P$. Pregnancy and gallstone disease. An empiric demonstration of the importance of specification of risk periods. Am J Epidemiol 1991; 134: 186-95

32 Hoskins TW, Davies JR, Smith AJ, Miller CL, Allchin A. Assessment of inactivated influenza-A vaccine after three outbreaks of influenza $A$ at Christ's hospital. Lancet 1979; i: 33-35

33 Palache AM, Beyer WEP, Sprenger MJW, Masurel N, Jonge S de, Vardy, et al. Antibody response after influenza immunization with various vaccine doses: a double-blind, placebo controlled multicentre, dose-response study in elderly nursing home residents and young volunteers. Vaccine 1993; 11: $3-9$

34 Helliwel Be, Drummond MF. The costs and benefit of preventing influenza in Ontario's elderly. Can J Public Health 1988; 79: 175-79

35 Riddough MA, Siks JE, Bell JC. Influenza vaccination; cost-effectiveness and public policy. JAMA 1983; 249: 3189-96

36 Maucher JM, Gambert SR. Cost-effective analysis of influenza vaccination in the elderly. Age 1990; 13: 81-85

37 Masurel N, Heytink RA. Recycling of H1N1 influenza A virus in man- a haemagglutinin antibody study. J Hyg Camb 1983; 90: 397-402 
$\sqrt{1}$

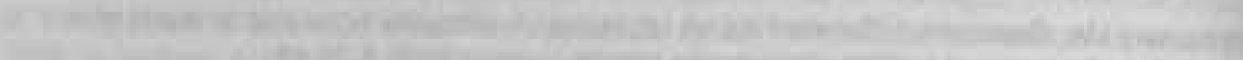

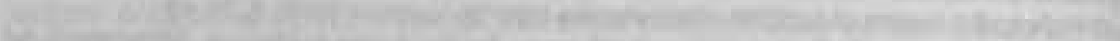

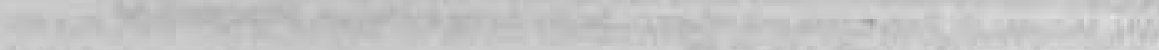

\section{4.}

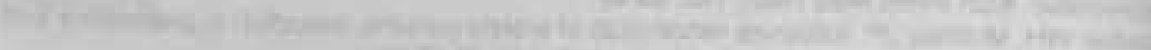
C17.

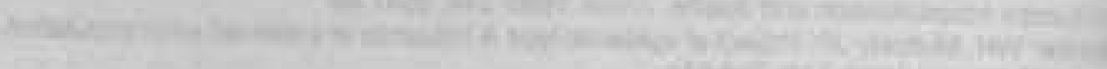
- the

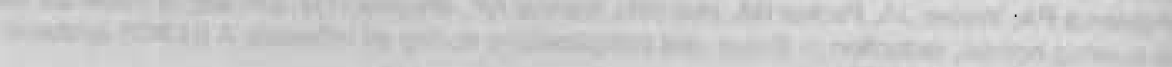

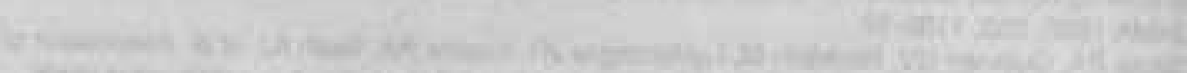
-

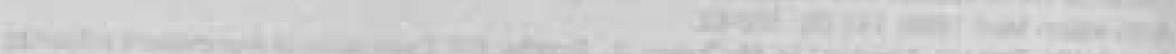

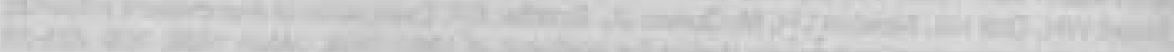
X.

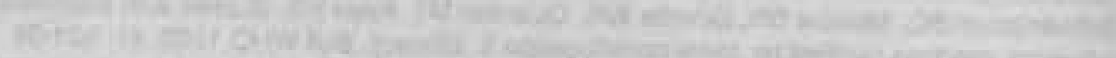

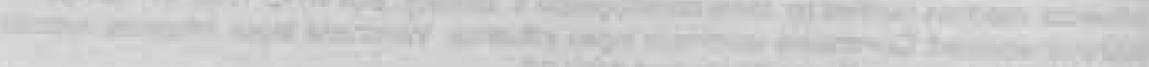

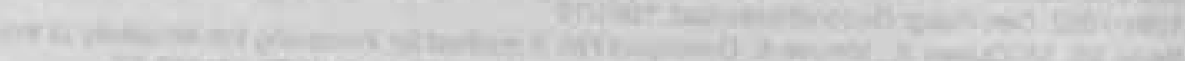

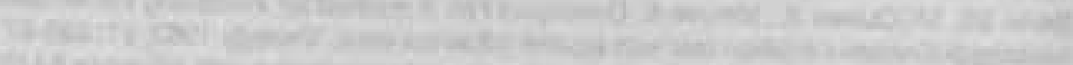

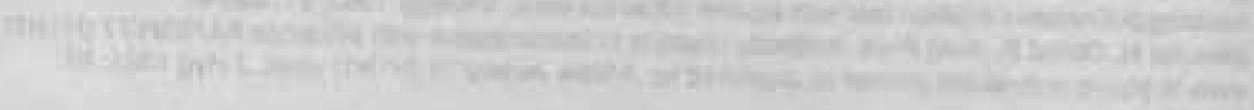

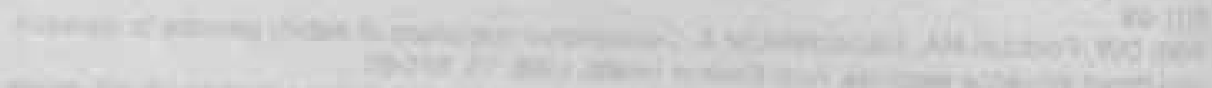
1h-

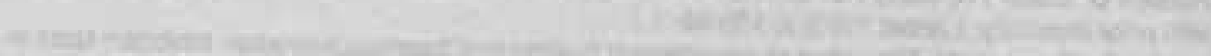

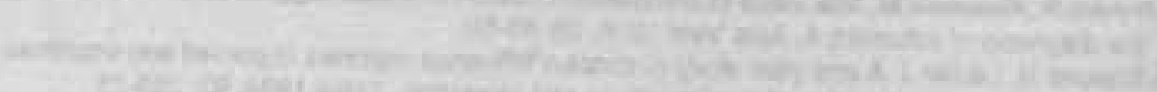

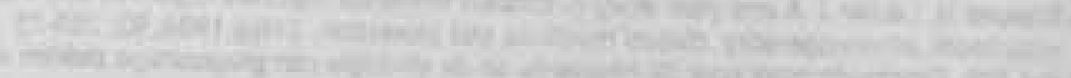
W

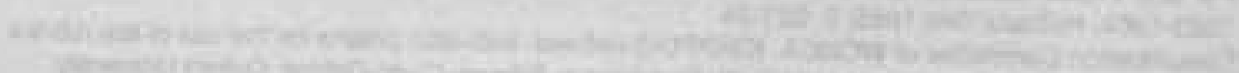

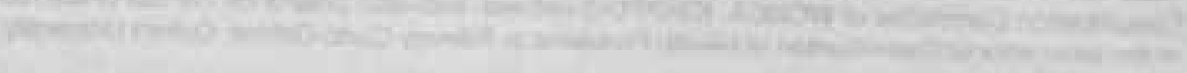

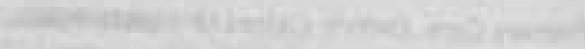
$\sqrt{2}$

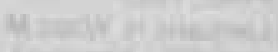

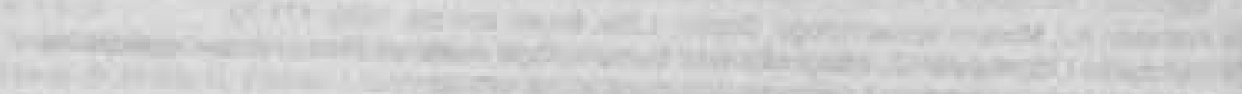

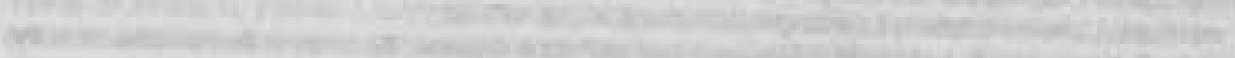

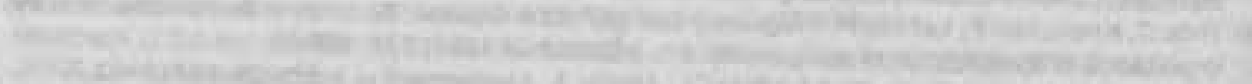

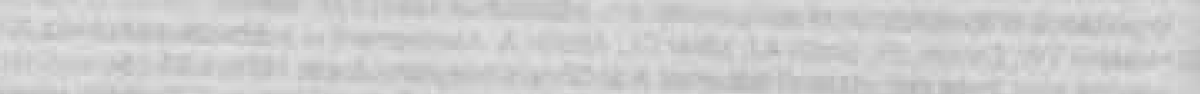

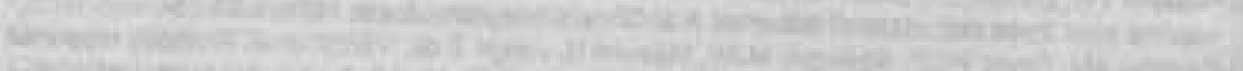

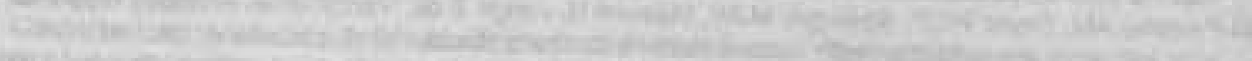

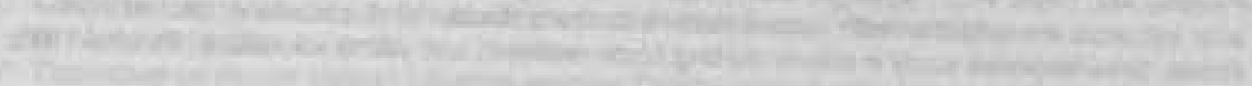

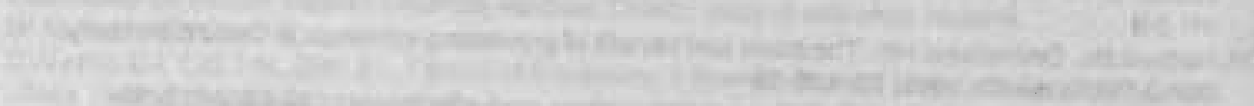

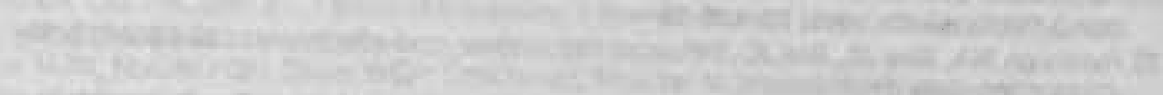

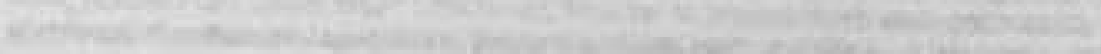

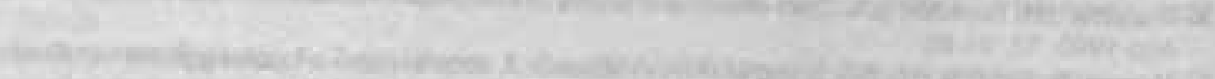

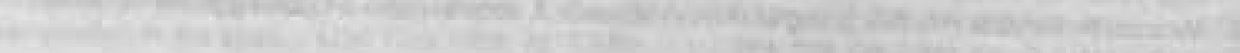


DEEL IV

\section{BESCHOUWING EN SAMENVATTING}

12 Beschouwing

13 Samenvatting

14 Summary

15 Alfabetische literatuurlijst 


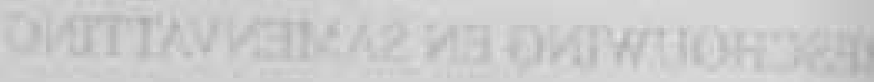

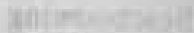

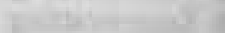

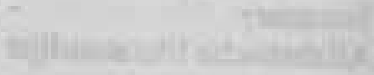




\section{HOOFDSTUK 12}

\section{BESCHOUWING}

Een prospectieve, gerandomiseerde, interventiestudie naar het effect van influenzavaccina-tie bij ouderen is om verschillende redenen moeilijk uitvoerbaar. Er kunnen zich medisch ethische problemen voordoen wanneer mensen, die steeds gevaccineerd zijn geweest, aan een gerandomiseerd onderzoek deelnemen. Oudere mensen, met name risicopatiënten, lopen een grotere kans op complicaties bij influenza dan jongeren (1-3). Daarnaast is de compliance van de deelnemers vooraf moeilijk in te schatten. Bovendien is de incidentie van influenza niet te voorspellen en weet men niet of de stammen gebruikt in het vaccin compatibel zullen zijn met de in het onderzoek circulerende virusstammen.

Uit het patiëntenbestand van 15 huisartspraktijken hebben wij desalniettemin een onderzoekpopulatie kunnen samenstellen die, na vergelijking van de leeftijdsopbouw en geslachtsverdeling met het steekproefbestand van het Registratienet Huisartspraktijken van de Rijksuniversiteit Limburg en die van de Nederlandse bevolking voldoende representatief blijkt te zijn voor een doorsnee bevolking van 60 jaar en ouder (4). Dezelfde conclusie geldt: voor de potentiële risicopatiënten $(4,5)$. De externe validiteit lijkt niet in gevaar te zijn gebracht door het aantal mensen dat weigerde $(81 \%)$ aan dit onderzoek deel te nenner. Immers het niet begrijpen van de uitnodigingsbrief, het huiverig zijn voor een onderzoek, de onduidelijkheid over het wel/niet aanstrepen in het antwoordformulier, angst voor de "prik" en bloedafnames en het teveel gebonden zijn in de tijd werden door veel mensen opgegeven als redenen van deze weigering. Het ligt niet voor de hand dat genoemde redenen gerelateerd waren aan leeftijd, geslacht en gezondheidstoestand.

Hoewel vaker getwijfeld wordt aan de kwaliteit van het afweersysteem bij oudere menseln $(6,7)$, blijkt uit dit onderzoek dat vaccinatie ook bij hen in een redelijke antilichaamtiter resulteert. Opvallend is wel dat de beschermingsgraad na vaccinatie per stam erg wisselend is. Een consequentie hiervan is dat ondanks een hoge vaccinatiegraad van risicopatiënten twijfels kunnen ontstaan over het nut van vaccinatie. Deze twijfels kunnen nog versterkt worden indien de in het vaccin gebruikte stammen niet compatibel zijn met de circulerende virusstam (8). Men zal ieder jaar opnieuw moeten blijven zoeken naar een vaccinsamenstelling die zoveel mogelijk identiek is aan de verwachte virusstammen. Bovendien zal men moeten trachten een procédé te vinden waarbij de beschermingsgraad na vaccinatie veel hoger wordt dan nu. Immers in de effectiviteitsstudie is vastgesteld dat alleen bij gevaccineerden met een voldoende hoge antilichaamtiter (voor de A-stammen $\geq 100$, voor de Bstammen $\geq 200$ ) zelden influenza voorkomt (tabel 11.6). Ook blijkt uit deze effectiviteitsstudie dat de deelnemers die reeds eerder gevaccineerd waren minder vaak influenza kregen 
dan de deelnemers die in dit onderzoek voor de eerste maal gevaccineerd werden. Dit is in tegenspraak met eerdere publicaties (9). Het komt ons voor dat de door eerdere vaccinaties verkregen antilichaamtiters de immuunrespons na een volgende vaccinatie zowel positief als negatief kunnen beïnvloeden $(10,11)$. De immuunrespons hoeft geen afspiegeling te zijn van de uiteindelijke bescherming van de gevaccineerde. Deze wordt waarschijnlijk zowel humoraal als cellulair bepaald. De huidige serologische bepalingen geven informatie over de humorale afweer. Over cellulaire afweer tegen influenza is nog weinig bekend. Verder onderzoek is hier gewenst.

Ondanks een mogelijk verminderd afweersysteem blijkt dat vaccinatie bij ouderen een reductie van influenza van ongeveer $50 \%$ oplevert. Hierbij moet bedacht worden dat gedurende de onderzoekperiode de incidentie van influenza en influenza-achtige ziekten laag was. Het is bekend dat het effect van vaccinatie relatief gunstiger is bij een epidemische verheffing $(12,13)$.

In deze studie is geen onderzoek gedaan naar het voorkómen door vaccinatie van ernstige morbiditeit en mortaliteit ten gevolge van influenza. Uit eerdere, weliswaar retrospectieve studies, werd geconcludeerd dat voor deze parameters het rendement van vaccinatie hoog is, $72 \%$ respectievelijk $87 \%(3,14)$. Om dit effect in een gerandomiseerde trial te onderzoeken, is een aanzienlijk groter onderzoekbestand noodzakelijk. Gezien de huidige aandacht voor het vaccinatiebeleid zal een dergelijk prospectief onderzoek in Nederland nauwelijks meer uitvoerbaar zijn. Het is te verwachten dat in de toekomst een hogere vaccinatiegraad bereikt wordt. Immers door voorlichting met name via de Nederlandse Influenza Stichting (5), zullen arts en patiënt wellicht meer overtuigd raken van het nut van vaccinatie. Een probleem hierbij is dat het effect van vaccinatie vaak in discrediet wordt gebracht doordat het klinisch beeld van influenza en influenza-achtige ziekte niet van elkaar is te onderscheiden (16-20) en vaccinatie niet beschermd tegen influenza-achtige ziekten.

Hoewel in Nederland door huisartsen steeds meer de ICPC wordt gebruikt voor het coderen van diagnosen hebben we in deze studie gekozen voor de ICHPPC-2-defined. Het merendeel der hoofdstukken is namelijk als artikel aan Engelstalige vakbladen aangeboden of erin gepubliceerd. Alleen in het hoofdstuk "Vaccinatie tegen influenza in een huisartspraktijk" is gebruik gemaakt van de ICPC omdat het voor dit onderzoek benodigde software programma (Micro-His) gebruik maakt van ICPC-codes.

De toegepaste methode voor het berekenen van de incidentie van influenza en influenzaachtige ziekten in de praktijk van de onderzoeker gedurende het seizoen 1990-1991 kan eeri vertekering van de resultaten hebben gegeven. Het invullen van de vragenlijsten kan onnauwkeurigheden met zich mee gebracht hebben. Immers, gegevens uit de periode waarover gerapporteerd moest worden konden gedeeltelijk vergeten zijn. Toch lijkt de gevonden incidentie een redelijk betrouwbare schatting van de werkelijke incidentie te zijn gezien de overeenstemming met die onder de deelnemers aan het multi-center onderzoek, één jaar later. Hierbij werden in dezelfde periode, week 43 tot en met week 13, 157 gevallen van influenza of een influenza-achtige ziekte gevonden bij 1838 deelnemers, dus een cumulatieve incidentie van $157 \times$ (10.000: 1838)= 854 per 10.000 inwoners indien de criteria van de peilstations in Nederland worden toegepast. Dit is, evenals de reeds beschreven cumulatieve incidentie, ongeveer het drievoudige van de door de peilstations opgegeven incidentie (245 per 10.000 inwoners). Weliswaar zijn deze incidenties niet berekend in hetzelfde jaar, maar in beide jaren was de landelijke incidentie laag. Ook de door de peilstations opgegeven incidentie van 245 per 10.000 inwoners is duidelijk lager dan de door ons berekende incidentie van serologisch bewezen influenza in dezelfde periode: $121 \times(10.000: 1838)=658$ per 10.000 inwoners.

Een veldstudie zoals in dit onderzoek uitgevoerd vereist, naast de nodige logistieke en financiële voorzieningen, de bereidwilligheid van een groot aantal huisartsen, hun assistentes en gemotiveerde vrijwilligers. Aangezien dit onderzoek seizoensgebonden was en maar eenmaal uitgevoerd kon worden moest een strak tijdschema worden gevolgd. Sommige 
huisartsen hadden weinig onderzoekervaring. Het was nodig om regelmatig de praktijken te bezoeken om de artsen te blijven motiveren en te betrekken bij de uitvoering en om eventuele problemen tijdig te traceren. Toch bleek het voor menig huisarts een opgave te zijn biji confrontatie met een mogelijk griepgeval de symptomen correct te registreren en bloed af te nemen. Voor zover er onderrapportage door de huisarten heeft plaats gevonden kan dit, door de dubbelblinde opzet, de resultaten van de trial niet vertekend hebben. Bovendien werd een dergelijke onderrapportage opgevangen door de door ons toegepaste sleepnet-methode onder de deelnemers. Ook eventuele "classificatie-ruis" is in beide groepen (vaccin/placebo) in gelijke mate opgetreden. Het probleem betrof overigens meestal de tijdsdruk en het niet alert zijn op het onderzoek. Opvallend was de terughoudendheid van de meeste, influenzavaccin bereidende industrieën. Dankzij de enthousiaste hulp van de beide apothekers vit ons dorp kon alsnog voldaan worden aan de voorwaarden van een gerandomiseerd, dubbelblind onderzoek.

Het feit dat de onderzoeker een oudere huisarts was met 31 jaar praktijkervaring in de regio, kwam de organisatie en uitvoering van dit onderzoek zeker ten goede. Hij had een gemakkelijke entree in de diverse praktijken en in het regionale ziekenhuis-laboratoriurn. Zo ook. kon hij voldoende capabele vrijwilligers vinden. Een nadeel van de oudere generatie huisartsen is dat ze te weinig wetenschappelijk geschoold zijn.

De samenwerking met een universitair huisartseninstituut is dan ook onontbeerlijk geweest voor het welslagen van de studie. Als slotconclusie zou ik willen stellen dat grotere veldstudies verricht in huisartspraktijken en geleid door huisartsen goed uitvoerbaar zijn, een waardevolle wetenschappelijke bijdrage leveren aan de huisartsgeneeskunde en een boeiende onderneming vormen. 


\section{LITERATUUR}

1 Sprenger M.JW. The impact of influenza: an epiderniological study of morbidity, direct mortality and related mortality [Thesis] Rotterdam: Erasmus Universiteit Rotterdam, 1990

2 Barker WH, Mullooly JP. Impact of epidemic, type A influenza in a defined adult population. Am J Epidemiol 1980; 112: 798-811

3 Barker WH, Mullooly JP. Influenza vaccination of elderly persons, reduction in pneumonia and influenza hospitalization and deaths. JAMA 1980; 244: 2547-49

4 Metsemakers JFM, Höppener P, Knottnerus JA, Kocken RJJ, Limonard ChBG. Computerized health information in the Netherlands; a registration network of family practices.

Br J Gen Pract 1992; 42: 102-06

5 Sprenger MJW, Masurel N. Influenzavaccinatie en de Postbus 51-campagne. Ned Tijdschr Geneeskd 1992; 136: 1968-70

6 Keren G, Segev S, Morag A, Zakay-Rones Z, Barzilai A, Rubinstein A. Failure of influenza vaccination in the aged. J Med Virol 1988; 25: 85-89

7 Strassburg MA, Greenland S, Sorvillo FJ, Lieb LE, Habel LA. Influenza in the elderly: report of an outbreak and a review of vaccine effectiveness reports. Vaccine $1986 ; 4: 38-44$

8 Beyer WEP, Bakker G, Beek R van, Masurel N. Influenza-epidemie in een verpleeghuis door een virus dat niet in het vaccin was opgenomen. Ned Tijdschr Geneeskd 1993; 137: 1973-77

9 Hoskins TW, Davies JR, Smith AJ, Miller CL, Allchin A. Assessment of inactivated influenza-A vaccine after three outbreaks of influenza $A$ at Christ's hospital. Lancet 1979; i: 33-35

10 Voth DW, Feldman HA, Steinschneider A. Comparative responses of elderly persons to aqueous and depot influenza vaccines. Arch Environ Health 1966; 13: 576-85

11 Hobson D. Baker FA, Curry RL. Effects of influenza vaccines in stimulating antibody in volunteers with prior immunity. Lancet 1973; ii: 155-56

12 Members of the commission on influenza et al. A clinical evaluation of vaccination against influenza. JAMA 1944; 124: 982-85

13 Thijs CTMCN, Knipschild PG, Leffers P. Pregnancy and gallstone disease. An empiric demonstration of the importance of specification of risk periods. Am J Epidemiol 1991; 134: 186-95

14 Patriarca PA, Weber JA, Parker RA, Hall WN, Kendal AP, Bregman DJ, Schonberger LB. Efficacy of influenza vaccine in nursing homes, reduction in illness and complications during an influenza A(H3N2) epidemic. JAMA 1985; 253: 1136-39

15 Housworth J, Langmuir AD. Excess mortality from epidemic influenza: 1957-1966. Am J Epidemiol 1974: $100: 40-48$

16 Pachucki CT. The diagnosis of influenza. Semin Resp Infect 1992; 7: 46-53

$17 \mathrm{Pel}$ JZS. Proefonderzoek naar de frequentie en de etiologie van griepachtige ziekten in de winter 1963-1964. Huisarts Wet 1965; 8: 321-24

18 Classification Committee of WONCA. ICHPPC-2-defined. Inclusion criteria for the use of the rubrics of the International Classification of Health Problems in Primary Care. Oxford: Oxford University Press, 1983

19 Lamberts $\mathrm{H}$, Wood M. International Classification of Primary Care. Oxford: Oxford University Press, 1983

20 Hannoun C, Dab W. Cohen JM. A new influenza surveillance system in France: the lle-de France "Grog". 1. Principles and Methodology. Eur J Epidemiol 1989; 5: 285-93 


\section{HOOFDSTUK 13}

\section{SAMENVATTING}

Jaarlijks sterven in Nederland ongeveer 2000 mensen direct of indirect tengevolge van influenza of influenza-achtige ziekten. Vijfennegentig procent van deze sterfte valt in de leeftijdscategorie van 60 jaar en ouder. Een van de mogelijkheden om influenza en de gevolgen daarvan te voorkomen is vaccinatie. Er wordt echter nog vaak getwijfeld aan het nuttig rendement van influenzavaccinatie. Het doel van deze studie is het onderzoeken van de effectiviteit van de vaccinatie. De volgende vraagstellingen hebben wij getracht te beantwoorden:

- Wat is de incidentie van influenza?

- Wat is de vaccinatiegraad met betrekking tot influenza in de huisartspraktijk?

- Wat is de voorspellende waarde van het symptomencomplex waarop de diagnose influenza wordt gesteld?

- Hoe lang is in het algemeen de ziekteduur ten gevolge van influenza?

- Wat zijn de bijwerkingen ten gevolge van influenzavaccinatie?

- Wat is de relatie tussen het niveau van antilichamen tegen influenza en het manifest worden van de ziekte?

- Wat is het rendement van influenzavaccinatie in termen van immuunrespons en preventie van de ziekte?

Het onderzoek bestaat uit een retrospectief (hoofdstuk 3 ), een prospectief observationeel (hoofdstuk 4) en een gerandomiseerde, dubbelblinde, placebo-gecontroleerde (RCT) studie (deel III).

Na een algemene inleiding (hoofdstuk 1) wordt in een historisch overzicht (hoofdstuk 2) de geschiedenis van het influenza-onderzoek beschreven. Door de steeds wisselende antigene structuur van het virus zal de noodzaak van onderzoek blijven bestaan.

Hoofdstuk 3 is een retrospectief onderzoek naar de incidentie van influenza en influenzaachtige ziekten uitgevoerd in een geassocieerde huisartspraktijk met 5746 patiënten. Alle, patiënten ontvingen aan het einde van het griepseizoen 1990-1991 een vragenlijst. Aan de hand van deze vragenlijsten werd berekend dat afhankelijk van de toegepaste diagnosecriteria (peilstations in Nederland of International Classification of Health Problems in Primary Care (ICHPPC-2-defined)) de cumulatieve incidentie van influenza en influenza-achtige ziekten in de onderzoekperiode $614 / 10.000$ respectievelijk $856 / 10.000$ bedroeg. Dit was drie respectievelijk vier maal het aantal dat door de peilstations werd opgegeven, 208/10.000. Deze onderrapportage kan veroorzaakt zijn door de methode van registreren van de peilstations: alleen contacten, geen registratie tijdens avonden, nachten en weekenden. 
Hoofdstuk 4 beschrijft een in dezelfde praktijk uitgevoerde prospectieve studie naar een methode om een betere vaccinatiegraad van risicopatiënten te bereiken. In de onderzochte praktijk was $5,6 \%$ van de populatie als risicopatiënt bekend. Door middel van het opnieuw beoordelen van alle patiëntendossiers, het gebruik van de praktijkcomputer en de computer van de plaatselijke apotheker werd bij $11,6 \%$ van de praktijkpopulatie een verhoogd risico gevonden. Door jaarlijks alle bekende risicopatiënten schriftelijk op te roepen werd een vaccinatiegraad van $93 \%$ bereikt. In vergelijking met andere studies (8\%-55\%) is dit hoog. In de hoofdstukken 5 en 6 worden wat betreft de RCT de gebruikte onderzoekmethoden en de algemene gegevens van de studiepopulatie uitvoerig beschreven. Van de deelnemers werd bij aanvang van de onderzoekperiode tweemaal een veneus bloedmonster afgenomen met een tussenpauze van drie weken, waarbij direct na de eerste bloedafname de deelnemers gevaccineerd werden met vaccin of placebo volgens een randomisatieprotocol. Aan het einde van de onderzoekperiode werd van alle deelnemers een laatste bloedmonster afgenomen. Een titerstijging van antilichamen in bloedmonster 2 ten opzichte van bloedmonster 1 wijst op een positieve immuunrespons op de vaccinatie. Een titer $\geq 38$ en een 4 -voudige titerstijging in bloedmonster 3 ten opzichte van bloedmonster 2 wijst op een influenza infectie. Aan de huisartsen werd gevraagd van de door hen geconsulteerde grieppatiënten de relevante symptomen te registreren. Tevens werd tijdens dit contact en drie weken later zo mogelijk ook een bloedmonster afgenomen. Aan de deelnemers werd gevraagd aan het einde van de eerste observatieperiode (1 novernber 1991 tot 1 januari 1992) en tweede observatieperiode ( 1 januari 1992 tot 15 april 1992) een enquête in te vullen met onder andere vragen over bijwerkingen tengevolge van de vaccinatie, het eventueel doorgemaakt hebben van een griepepisode en de symptomen die zich hierbij voordeden. Ook tussentijds konden de deelnemers een vragenlijst opsturen indien zij meenden griep te hebben. De criteria volgens welke door de peilstations in Nederland en de International Classification of Health Problems in Primary Care (ICHPPC-2-defined) de diagnose influenza of influenzaachtige ziekte (IAZ) wordt gesteld, werden gebruikt voor het evalueren van de enquêtelijsten.

De onderzoekperiode bedroeg 5 maanden (1 november 1991 tot 15 april 1992). In totaal namen 34 huisartsen, verdeeld over 15 huisartspraktijken in de regio Zuid-Limburg, deel aan het onderzoek. De totale praktijkpopulatie bedroeg 68.988 patiënten. Patiënten jonger dan 60 jaar, patiënten behorende tot een risicogroep en patiënten die in verzorgings- of verpleegtehuizen verbleven werden uitgesloten. Van de 9907 overblijvende patiënten stemden 1838 patiënten toe in deelname: 869 mannen, 969 vrouwen, gemiddelde leeftijd 67 jaar (SD 6, mediaan 66, range 60-91 jaar). Van de deelnemers bleken er 185 in 1989 en 1990 gevaccineerd te zijn. Verder werd door 490 deelnemers alsnog een hartaandoening $(n=249)$, longaandoening $(n=200)$ of diabetes mellitus $(n=41)$ gemeld. Deze aandoeningen waren naar het gordeel van de huisarts niet van dien aard dat vaccinatie noodzakelijk was. De deelnemende huisartsen leken het begrip "risicopatiënt" verschillend te interpreteren. Om het effect van vaccinatie bij patiënten met een mogelijk verhoogd risico te beoordelen, werden de deelnemers ingedeeld in vier strata: hartaandoeningen, longaandoeningen, diabetes mellitus en overige aandoeningen of gezonde deelnemers. De deelnemers werden volgens deze stratificatie gerandomiseerd gevaccineerd met vaccin of placebo. Er werden $420(45,3 \%)$ mannen en $507(54,7 \%)$ vrouwen gevaccineerd. Placebo werd toegediend aan $449(49,3 \%)$ mannen en $462(50,7 \%)$ vrouwer. De vaccin- en placebogroep waren goed vergelijkbaar qua leeftijd, geslacht, potentiële risicostatus en het al of niet eerder gevaccineerd zijn. Van de 1838 deelnemers beëindigden 22 het onderzoek voortijdig; 13 uit de vaccingroep, 9 uit de placebogroep. De redenen van uitval vertoonden geen relatie met influenza of een influenza-achtige ziekte.

Met serologisch bewezen influenza als gouden standaard wordt in hoofdstuk 7 beschreven welk symptomencomplex de grootste voorspellende waarde voor de diagnose influenza had. Ook werd de validiteit van de diagnostische conclusie van de huisarts en die volgens 
de criteria van de ICHPPC-2-defined en de peilstations nagegaan. De combinatie koorts, hoesten en acuut begin had de grootste voorspellende waarde bij het differentiëren tussen influenza en influenza-achtige ziekten $(30,3 \%)$. De voorspellende waarde van de diagnostiek van de huisarts bedroeg $35 \%$ en die volgens de beide classificatiemethoden $24 \%$ (voor de peilstations) en $18 \%$ (voor de ICHPPC-2-defined). Het zou aan te bevelen zijn de huidige criteria van de ICHPPC-2-defined en de peilstations aan te passen in die zin dat men mag spreken van influenza indien van de symptomen acuut begin, hoesten, koude rillingen, koorts, algehele malaise, hoofdpijn, spierpijnen, rode keel of rhinitis en contact met influenza, minstens de volgende symptomen aanwezig zijn: koorts, hoesten en een acuut begin.

In hoofdstuk 8 wordt de ziekteduur van influenza-achtige ziekten bij ouderen beschreven. Oudere patiënten waren gemiddeld 7 dagen ziek tengevolge van influenza-achtige ziekten en onderbraken gedurende 4 dagen hun dagelijkse bezigheden. Er kon geen statistisch significant verschil gevonden worden wat betreft ziekteduur en periode van werkonderbreking tussen gevaccineerden en niet gevaccineerden, risico- en niet risicopatiënten, mannen en vrouwen en tussen patiënten met een influenza-achtige ziekte waarbij influenza serologisch wel of niet aanwezig was. Er werd geen steun gevonden voor de opvatting dat de ziekteduur tengevolge van griep stijgt met het ouder worden.

In hoofdstuk 9 wordt beschreven in welke mate de influenzavaccinatie bijwerkingen veroorzaakte. Van de gevaccineerden meldden $17,5 \%$ locale bijwerkingen, van de niet gevaccineerden $7,3 \%(\mathrm{p}<0,001)$. Bij systemische bijwerkingen was er geen statistisch significant verschil tussen gevaccineerden en niet gevaccineerden (11\% versus $9,4 \%$; $\mathrm{p}=0,34$ ). Risicopatiënten toonden een zelfde patroon. Mannen meldden duidelijk minder bijwerkingen dan vrouwen, zowel in de vaccin- als in de placebogroep. Onder deelnemers die reeds eerder gevaccineerd waren en deelnemers ouder dan 69 jaar werd minder verschil in de frequentie van bijwerkingen tussen vaccin- en placebogroep gevonden. Gezien het milde karakter van de bijwerkingen en de voorbijgaande aard ervan lijkt afzien van vaccinatie wegens kans op bijwerkingen niet terecht.

Hoofdstuk 10 beschrijft de grootte van de immuunrespons, na vaccinatie uitgedrukt in een geometrisch gemiddelde titer (GMT) en protection rate (PR: percentage deelnemers met een beschermende antilichaamtiter). Afhankelijk van de onderzochte stam werd een beschermende antilichaamtiter gevonden bij $43 \%$ tot $68 \%$ van de gevaccineerde deelnemers. Dit resultaat was statistisch significant ten opzichte van de placebogroep. Deelnemers die de voorafgaande twee seizoenen waren gevaccineerd toonden een geringere immuunrespons dan deelnemers die voor de eerste maal gevaccineerd werden. Toch bleek bij de eerder gevaccineerden die nu vaccin respectievelijk placebo ontvingen, in de vaccingroep statistisch significant minder frequent serologisch influenza voor te komen dan in de placebogroep $(0,9 \%$ versus $5,1 \%)$. Kennelijk speelt behalve een humorale immuniteit, ook de cellulaire afweer een belangrijke rol bij het effect van influenzavaccinatie.

Hoofdstuk 11 beschrijft het effect van vaccinatie op het voorkómen van influenza. Vaccinatie gaf een risico reductie van $50 \%$ ten aanzien van de serologisch bevestigde diagnose en $17 \%$ indien de criteria van de ICHPPC-2-defined gehanteerd werden. Bij toepassing van de ICHPPC-2-defined-criteria worden veel patiënten "fout positief" gediagnostiseerd. Dit veroorzaakte een verdunning van het effect van vaccinatie. Van de 121 deelnemers, met serologisch bewezen influenza bleek van de 41 gevaccineerden $91 \%$ geen beschermende antilichaamtiter te hebben. Kennelijk was de vaccinatie bij deze deelnemers niet aangeslagen. Verder bleek dat van deze 121 slechts $54(45 \%)$ deelnemers klinische verschijnselen vertoonden. Bij de overige 67 deelnemers (zonder symptomatologie) bleken er wel antilichamen tegen influenza aanwezig te zijn. De hoogte hiervan was kennelijk voldoende om het optreden van symptomen te voorkomen. 


\section{SLOTCONCLUSIE}

Het feit dat de incidentie van influenza en influenza-achtige ziekten hoger lijkt te zijn dan de officiële gegevens doen vermoeden, dat de vaccinatiegraad van de risicogroepen bij een goede organisatie en voorlichting aanzienlijk verhoogd kan worden, dat bijwerkingen ten gevolge van vaccinatie mild zijn, dat door vaccinatie de kans op het krijgen van influenza bij ouderen met $50 \%$ wordt gereduceerd en dat $95 \%$ van de mortaliteit tengevolge van influenza plaats vindt in de leeftijdsgroep van 60 jaar en ouder, pleit tezamen voor een optimalisering van de vaccinatiegraad met betrekking tot influenza bij ouderen. 


\section{HOOFDSTUK 14}

\section{SUMMARY}

Every year approximately 2000 people die as a direct or indirect result of influenza or influenza-like illnesses. Ninety-five percent of these deaths occur in the age category sixty and older. One of the means to prevent influenza and its consequences is vaccination. However, the effectiveness of vaccination is still widely questioned. The objective of this investigation is to study the efficacy of vaccination. We have attempted to answer the following research questions:

- What is the incidence of influenza?

- What is the degree of vaccination in general practice with regard to influenza?

- What is the predictive value of the complex of symptoms on which the diagnosis of influenza is based?

- What is the general duration of illness as a result of influenza?

- What are the side effects of influenza vaccination?

- What is the relationship between the antibody titre against influenza and the manifestation of the illness?

- What is the efficacy of influenza vaccination in terms of immune response and illness prevention?

The study comprises a retrospective study (chapter 3 ), a prospective observational study (chapter 4) and a randomised double blind placebo controlled (RCT) trial (part III).

The general introduction (chapter 1) is followed by a historical overview of influenza research (chapter 2). As a result of the ever changing antigen structure of the virus, the need for research will always exist.

Chapter 3 covers a retrospective study of the incidence of influenza and influenza-like illnesses in an associated general practice with 5746 patients. All patients received a questionnaire at the end of the 1990-1991 influenza season. On the basis of the questionnaire, the cumulative incidence of influenza and influenza-like illnesses in the practice examined appeared to be $614 / 10,000$ and $856 / 10,000$, based on Dutch Sentinel-station crite-ria and International Classification of Health Problems in Primary Care (ICHPPC-2-defined) criteria respectively. These numbers were respectively three and four times higher than the number reported by the Dutch Sentinel stations, namely $208 / 10,000$. This lower estimation may have been the result of the method of registration at the Sentinel stations: only registration of patient contacts, no registration during evenings, nights and weekends.

Chapter 4 describes a prospective study in the same general practice, in which the aim was. to find a method to obtain a better degree of vaccination of risk patients. In the general prac- 
tice under study, $5.6 \%$ of the population were known as risk patients. After re-evaluating all patient records and accessing the computer of the general practice and the local pharmacy, $11.6 \%$ of the patient population were found to have a higher risk. By annually sending a vaccination notice to all known risk patients, a vaccination rate of $93 \%$ was achieved. This is high in comparison to other studies (8-55\%).

Chapters 5 and 6 provide a detailed description of the research methods used in the RCT and the general characteristics of the research population. At the start of the research period, two venous blood samples were taken from the participants at a three week interval. Immediately after the first sample was taken, participants were vaccinated with a vaccine "Griep vaccin $\mathrm{PCH}^{\prime \prime}$ (Fluvirin") produced by Evans, England, or a placebo according to a randomisation protocol. At the end of the research period a final blood sample was taken from all participants. A titre increase in sample 2 relative to sample 1 indicates a positive immune response to the vaccination. A titre $\geq 38$ and a four-fold titre increase in blood sample 3 relative to blood sample 2 indicates an influenza infection. The general practitioners were asked to record the relevant symptoms of the flue patients who had consulted them. When possible, blood samples were taken during this consultation and again three weeks later. Participants were asked to complete a questionnaire at the end of the first research period (1 November 1991 - 1 January 1992) and at the end of the second research period (1 January 1992 - 15 April 1992). The questionnaire included questions about the side effects of the vaccination, whether or not a flue episode was experienced and if so, what symptoms ocurred. Participants could also fill in a questionnaire in the interim if they thought they had flue. The questionnaires were evaluated according to the criteria for diagnosing influenza or influenza-like illnesses used by the Sentinel stations in the Netherlands and by the International Classification of Health Problems in Primary Care (ICHPPC-2-defined).

The research period covered 5 months (1 November 1991 to 15 April 1992). In total, 34 general practitioners from 15 general practices throughout South Limburg participated in this study. The entire patient population comprised 68,988 patients. Patients younger than 60 years of age, patients belonging to a risk category and patients residing at retirement homes or nursing homes were excluded. Of the 9907 remaining patients, 1838 patients agreed to participate: 869 men, 969 women, average age 67 (SD 6, median 66, range 60-91 years of age). Of these patients, 185 had been vaccinated in 1989 and 1990. In addition, 490 patients reported a heart condition $(n=249)$, a lung condition $(n=200)$ or diabetes mellitus $(\mathrm{n}=41)$. According to the general practitioners, these conditions did not require vaccination. The participating general practitioners appeared to interpret the concept 'risk patient' differently. To asses the effect of potentially risk status on the effect of vaccination we devided subjects into four categories: heart conditions, lung conditions, diabetes mellitus and other conditions or healthy. The participants were randomly vaccinated with vaccine or placebo according to this stratification. Four hundred and twenty (45.3\%) men and 507 (54.7\%) women were vaccinated. A placebo was administered to 449 men (49.3\%) and 462 women $(50.7 \%)$. The vaccine and placebo groups were similar with regard to age, gender, potential risk status and prior vaccination status. Of the 1838 participants, 22 withdrew before the end of the investigation: 13 from the vaccine group and 9 from the placebo group. The reason for withdrawing was not related to influenza or an influenza-like illness.

Chapter 7 describes the complex of symptoms that had the highest predictive value for the diagnosis of influenza, using serologically confirmed influenza as the golden standard. In addition, the validity of the diagnostic conclusion of the general practitioner and according to the criteria of the ICHPPC-2-defined and the Sentinel stations are examined. The combination of fever, coughing and an acute onset had the highest predictive value for differentiating between influenza and influenza-like illnesses $(30.3 \%)$. The predictive value of the general practicioners'diagnostics was $35 \%$, of the two classification systems $24 \%$ (Sentinel stations) and 18\% (ICHPPC-2-defined). It is recommended that the present criteria of the ICHPPC-2-defined and the Sentinel stations be adjusted so that a diagnosis of influenza can 
be made if, of the symptoms acute onset, coughing, chills, fever, total malaise, headaches, muscle aches, sore throat or rhinitis, and contact with influenza, at least the following symptoms are present: fever, coughing and an acute onsett.

Chapter 8 describes the duration of illness as a result of influenza-like illnesses in elderly patients. On average, elderly patients were ill for 7 days and abstained from their daily activities for 4 days. No statistically significant difference was found with regard to the duration of illness and abstaining from work between vaccinated and non-vaccinated patients, potential risk and no-risk patients, men and women and between patients with an influenzalike illness with or without serological proof for influenza. No evidence was found to support the notion that the duration of illness increases as age increases.

Chapter 9 describes the degree to which influenza vaccination caused side effects. Of the subjects who were vaccinated, $17.5 \%$ reported local side effects; of the non-vaccinated subjects $7.3 \%$ reported side effects $(p<0.001)$. For systemic side effects, no statistically significant difference was found between vaccinated and non-vaccinated subjects $(11 \%$ versus $9.4 \% ; p=0.34$ ). A similar pattern was found for potential risk patients. In both the vaccine and the placebo group, men reported noticably fewer side effects than women. Among participants who had been vaccinated before and among participants older than 69 years of age, the difference in the frequency of side effects between the vaccine and the placebo group was found to be smaller. In light of the mild and temporary nature of the side effects, it does not seem justified to abandon vaccination on the grounds of possible side effects.

Chapter 10 describes the extent of the immune response after vaccination, expressed in terms of a geometric mean titre (GMT) and a protection rate (PR: the percentage of participants with a protective antibody titre). Depending on the strain being studied, a protective antibody titre was found in $43 \%$ to $68 \%$ of the vaccinated participants. This result was statistically significant in relation to the placebo group. Subjects who had been vaccinated in the previous two seasons showed a lower immune response than those vaccinated for the first time. Nevertheless, serological influenza occured significantly less often in the vaccine group than in the placebo group $(0.9 \%$ versus $5.1 \%$ ). In addition to humoral immunity, measured by the GMT and PR, cellular resistance also appears to play an important role in the effect of influenza vaccination.

Chapter 11 describes the effect of vaccination on the prevention of influenza. Vaccination resulted in a risk reduction of $50 \%$ with regard to serologically confirmed diagnosis and $17 \%$ if the criteria of the ICHPPC-2-defined were used. The ICHPPC-2-defined criteria are susceptible to a great deal of interference as a result of which many non-influenza cases are wrongly diagnosed. This dilutes the effect of vaccination. Of the 121 participants with serologically diagnosed influenza, 41 of the vaccinated subjects $(91 \%)$ did not have a protective titre. Apparently, vaccination was not successful in these patients. Furthermore, of these 121 participants only $54(45 \%)$ showed clinical symptoms. The remaining 67 participants (lacking symptomatology) did have antibodies against influenza. The antibody level was apparently high enough to prevent the symptoms from appearing.

\section{CONCLUSION}

It is evident that the degree of vaccination against influenza among the elderly and risk groups should be optimalized: firstly, the incidence of influenza and influenza-like illnesses appears to be higher than the official figures indicate; secondly, the degree of vaccination of risk patients can be substantially improved with good organisation and information; thirdly. the side effects of the vaccine are mild; lastlty, in elderly people vaccination reduces the chance of contracting influenza by $50 \%$ and $95 \%$ of mortality as a result of influenza occurs in the age group 60 and older. 


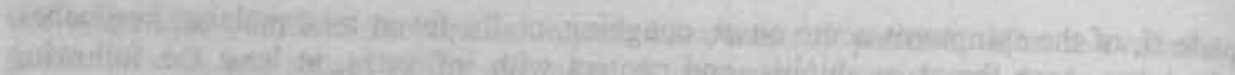

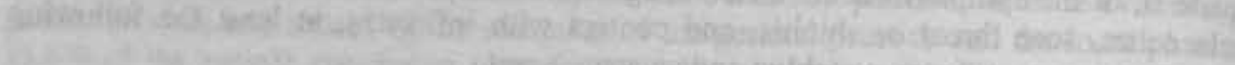

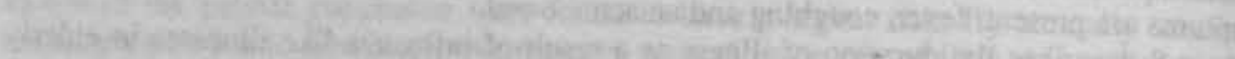

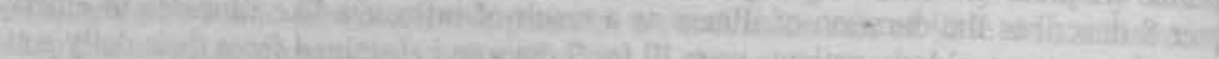

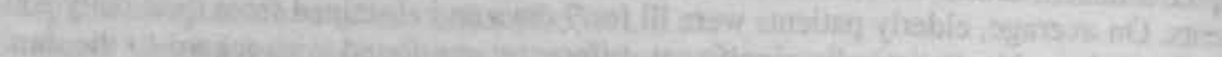

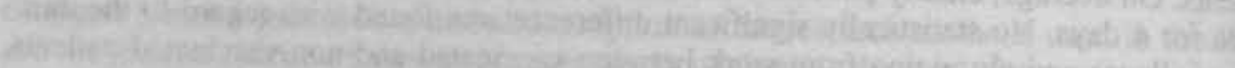

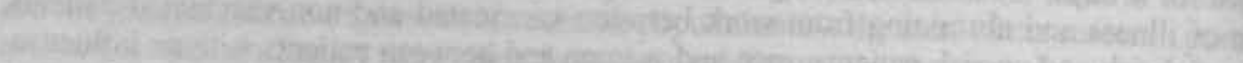

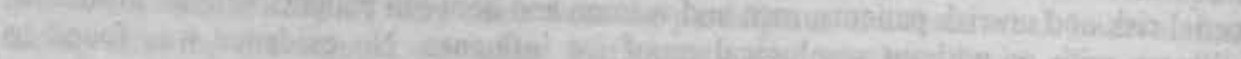

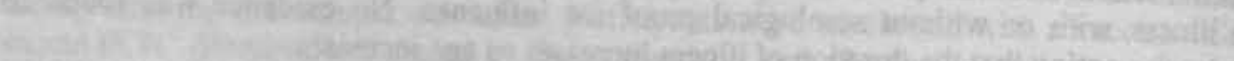

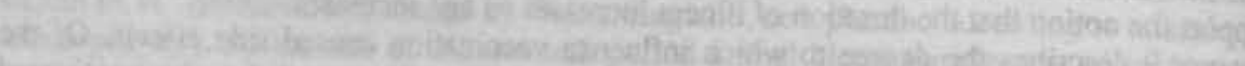

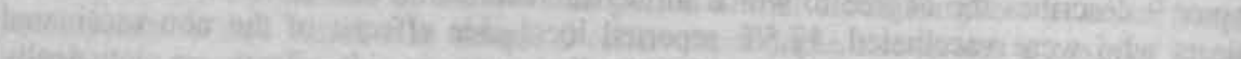

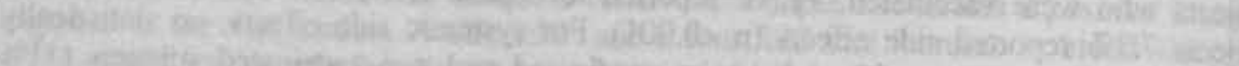

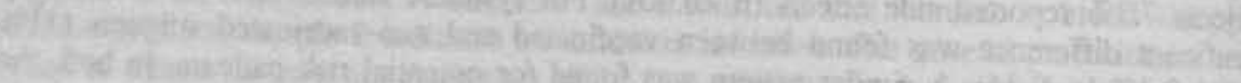

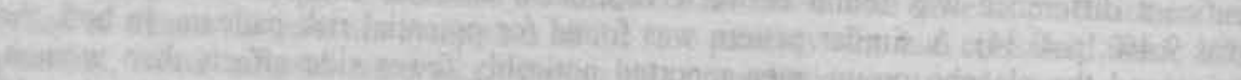

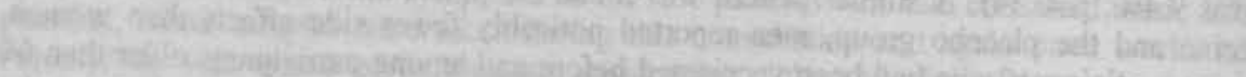

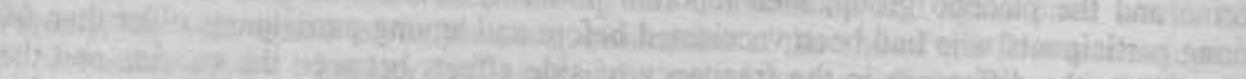
3.

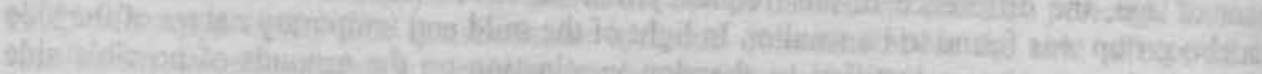

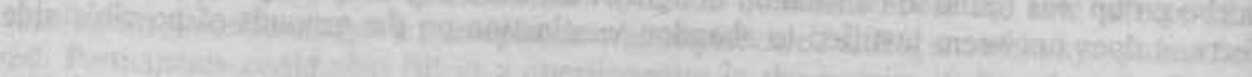

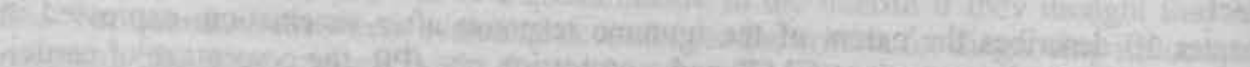

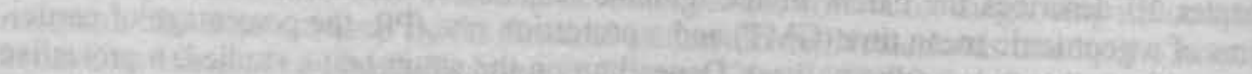

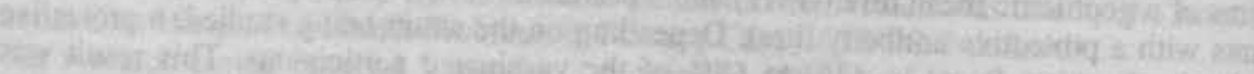

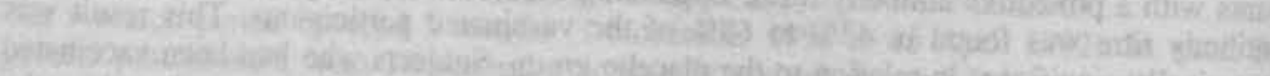

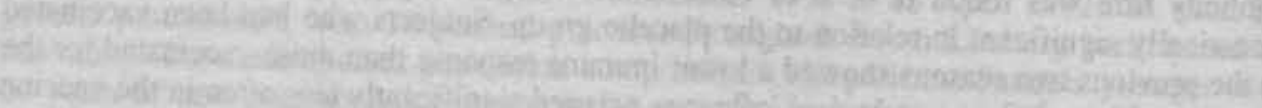

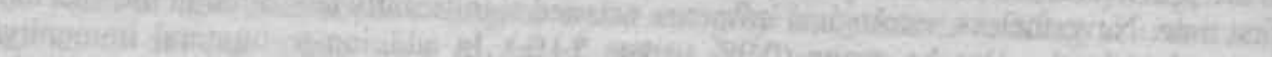

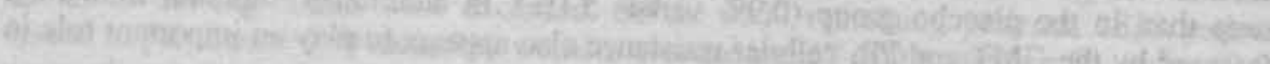

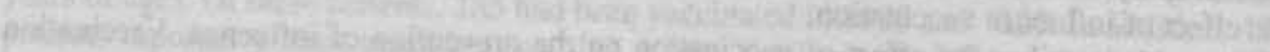
Wulwherelh the 5x-

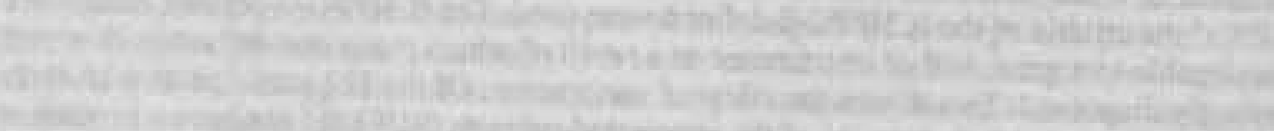

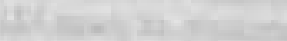

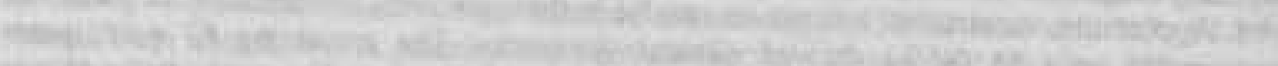

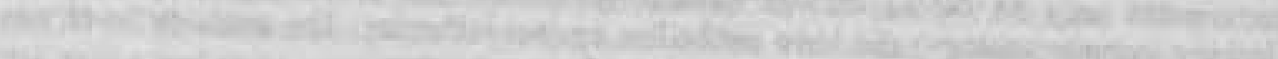

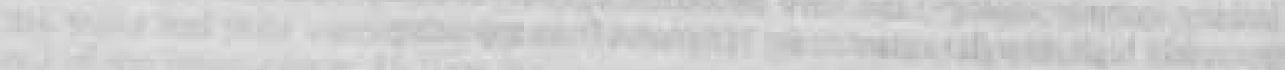

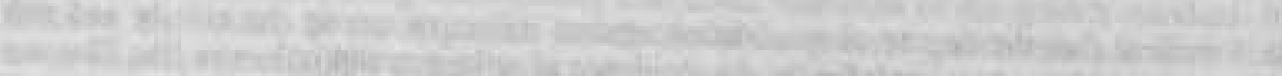

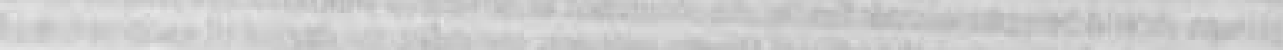

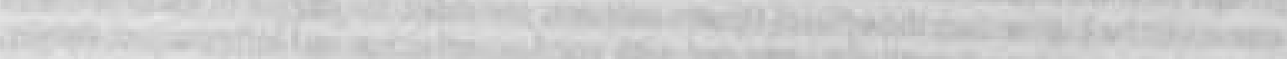

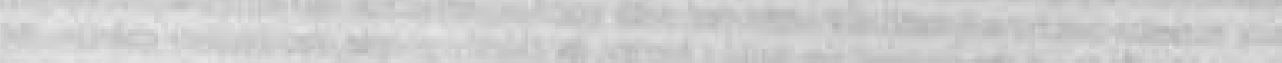

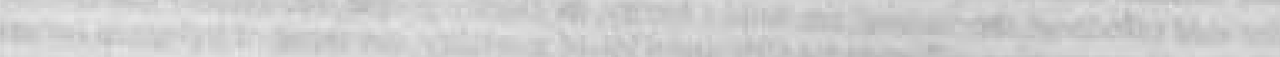

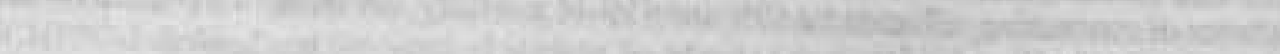

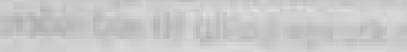




\section{HOOFDSTUK 15}

\section{ALFABETHISCHE LITERATUURLIJST}


- Alling DW, Blackwelder WC, Stuart-Harris CH. A study of excess mortality during influenza epidemics in the United States, 1968-1976. Am J Epidemiol 1981; 113: 30-43

- Bachmeyer H, Licht E, Schmidt G. Preparation and properties of a novel influenza subunit vaccine. Postgrad Med J 1976; 52: 360-67

- Baker CC, Cameron AS. The effect of influenza immunization on absence. J Soc Occup Med 1985; 35: 134-36

- Barker WH. Excess pneumonia and influenza associated hospitalization during influenza epidemics in the United State 1970-78. Am J Public Health 1986; 76: 761-65

- Barker WH, Mullooly JP. Impact of epidemic, type A influenza in a defined adult population. Am J Epidemiol 1980; 112: 798-811

- Barker WH, Mullooly JP. Influenza vaccination of elderly persons, reduction in pneumonia and influenza hospitalization and deaths. JAMA 1980;244: 2547-49

- Barker WH, Mullooly JP. Pneumonia and influenza deaths during epidemics. Implications for prevention. Arch Intern Med 1982; 142: 85-89

- Berlin BS, MCQueen JL, Minuse E, Davenport FM. A method for increasing the sensitivity of the haemagglutination-inhibition test with equine influenza virus. Virology 1963; 21: 665-67

- Beyer WEP, Teunissen MWE, Diepersloot RJA, Masurel N. Immunogenicity and reactogenicity of two doses of trivalent influenza split vaccine. An open randomized study in healthy, unprotected, adult volunteers. J Drug Ther Res 1986; 9: 369-74

- Beyer WEP, Bakker G, Beek R van, Masurel N. Influenza-epidemie in een verpleeghuis door een virus dat niet in het vaccin was opgenomen.Ned Tijdschr Geneeskd 1993; 137: 1973-77

- Beyer WEP, Palache AM, Baljet M, Masurel N. Antibody induction by influenza vaccines in the elderly: a review of the literature. Vaccine 1989; 7: 385-94

- Brimberry R. Vaccination high-risk patients for influenza. A comparison of telephone and mail reminder methods. J Fam Pract 1988; 26: 397-400

- Buchner DM, Larson EB, White RF. Influenza vaccination in community elderly. A controlled trial of postcards reminders. J Am Geriatr Soc 1987; 35: 755-60

- Cameron AS, Roder DM, Esterman AJ, Moore BW. Mortality from influenza and allied infections in South Australia during 1968-1981. Med J Aust 1985; 142: 14-17

- Cate TR, Kasel JA, Couch RB, Six HR, Knight V. Clinical trials of bivalent influenza A/New Jersey/76- A/Victoria/75 vaccines in the elderly. J Infect Dis 1977; 136: 5518-25

- Centraal Bureau voor de Statistiek, Ministerie van Welzijn, Volksgezondheid en Cultuur. Vademecum gezondheidsstatistiek Nederland 1992. Den Haag: CBS-publikaties, $1992 / 893$

- Centres for disease control influenza vaccination coverage levels in selected sites. United States, 1989. MMWR 1990; 39: (10): 111-13

- Chan ED. Reye's syndrome in a young adult. Milit Med 1993; 158: 65-68

- Classification Committee of WONCA. ICHPPC-2-defined. Inclusion criteria for the use of the rubrics of the International Classification of Health Problems in Primary Care. Oxford: Oxford University Press, 1983

- Collette HJA, Bijkerk H. Vijftien jaar Peilstations Nederland, 1970-1984. Huisarts Wet 1985; 28:207-10.

- Committee on clinical trials of influenza vaccine. Clinical trials of influenza vaccine. Br Med J 1953; 2: 1173-77

- Connolly AM, Salmon RL, Lervy B, Williams DH. What are the complications of influenza and can they be prevented? Experience from the 1989 epidemic of H3N2 influenza A general practice. Br Med J 1993; 306; 1452-54

- Couch RB, Webster RG, Kasel JA, Cate TR. Efficacy of purified influenza subunit 
vaccines and relation to the major antigenic determinants on the haemagglutinin molecule. J Inf Dis 1979; 140: 553-59

- Crawford CR, Mukhlis FA, Jennings R, Oxford JS, Hockley DJ, Potter CW. Use of zwitterionic detergent for the preparation of an infleunza virus vaccine. I: preparation and characterization of disrupted virions. Vaccine 1984; 2 : 193-98

- Cristea Al, Deutch I, Copelovici Y, Dobre M, Cajal N, Pavel A, et al. Computerized studies of influenza epidemiology in the Sibiu country between 1968 and 1986. Rev Roum Med Virol 1988; 39: 15-20

- D'Alesso DJ, Cox PM, Dick EL. Failure of inactivated influenza vaccine to protect aged population. JAMA 1969; 210: 485-89

- Diepersloot RJA. Influenza and diabetes; immunological and epidemiological aspects. [Thesis]. Rotterdam: Erasmus Universiteit Rotterdam, 1989

- Diepersloot RJA, Bouter KP, Hoekstra JBL. Influenza infection and diabetes mellitus: a case for annual vaccination. Diabetes Care 1990; 13: 876-82

- Diepersloot RJA, Sprenger MJW. Influenza: the old man's friend? Mod Med 1991; 759-63

- Dixon WJ. BMDP statistical manual. California, Berkeley: University of California Press, 1981

- Douglas RG. Prophylaxis and treatment of influenza. New Engl J Med 1990; 322: 443-50

- Duthie jr EH, Rabinovitch RA, Rose HD, Tsitouras P, Gambert SR. Effectiveness of influenza vaccination in a long-term care setting. Wis Med J 1984; 83: 11-12

- Edmonson jr WP, Rothenberg R, White PW, Gwaltney jr JM. A comparison of subcutaneous, nasal, and combined influenza vaccination. II. Protection against natural challenge. Am J Epidemiol 1971; 93: 480-86

- Eickhoff TC, Sherman IL, Serfling RE. Observations on excess mortality associated with epidemic influenza. JAMA 1961; 176: 776-83

- Eraker SA, Kirscht JP, Becker MH. Understanding and improving patient compliance. Ann Intern Med 1984; 100: 258-68

- Essen GA van. Oproepen voor de influenzavaccinatie. Een regionale enquête. Huisarts Wet 1991; 34: 416-18

- Essen GA van. Oproepen van alle 65-plussers voor de influenzavaccinatie.

Een onderzoek in drie huisartspraktijken naar opkomst, motivatie en kennis. Huisarts Wet 1992; 35: 345-49

- Evans DB, Hensley MJ, O'Connor SJ. Influenza vaccination in Australia: a review of the economic evidence for policy recommendations. Med J Aust 1988; 149: 540-43

- Fattal-German M, Thaillandier J, Mathieu D, Bauman F, Bizzini B. Usefulness, of influenza vaccination in the elderly. Biomed Pharmacother 1991; 45: 29-32

- Fedson DS, Wajda A, Nicol JP, Hammond GW, Kaiser DL, Roos LL. Clinical effectiveness of influenza vaccination in Manitoba. IAMA 1993; 270: 1956-61

- Fleming DM, Crombie DL. The incidence of commnon infectious diseases: the weekly returns service of the Royal College of General Practitioners. Health Trends 1985; 17: $13-16$

- Fleming DM, Ayres JG. Diagnosis and patterns of incidence of influenza, influenza-like illnes and the common cold in general practic. J R Coll Gen Pract 1988; 38: 159-62

- Francis T jr, Salk JE, Quilligan JJ jr. Experience with vaccination against influenza in the spring of 1947. Am J Public Health 1947; 37: 1013-16

- Frank JW, McMurray L, Henderson M. Influenza vaccination in the elderly: 2.

The economics of sending reminder letters. Can Med Assoc J 1985; 132: 516-18, 521

- Fried LP, Bush TL. Morbidity as a focus of preventive health care in the elderly.

Epid Rev 1988; 10: 48-64 
- Ganguly R, Schler S, Vargas L, Cameron D, Chmel H, Benhke RH. Reasons for nonimmunization against influenza in the aged. J Am Geriatr Soc 1989; 37: 387-93

- Gardner ID. The effect of aging on susceptibility to infection. Rev Infect Dis 1980; 25: $801-10$

- Geneeskundige Hoofdinspectie van de Volksgezondheid, Advies inzake vaccinatie tegen influenza. Rijswijk: GHI/INFZ, 1989.

- Gezondheidsraad: Commissie vaccinatie tegen influenza. Vaccinatie tegen influenza; seizoen 1991-1992. Den Haag: Gezondheidsraad, 1991/15

- Gill PW, Murphy AM. The diagnosis of influenza. Aust Fam Phys 1991; 20: 1664-65

- Glezen WP, Decker M, Perrotta DM. Survey of underlying conditions of persons hospitalized with acute respiratory disease during influenza epidemics in Houston 1978- 1981. Am Rev Respir Dis 1987; 136: 550-55

- Glezen WP. Prevention of influenza-related morbidity and mortality. Arch Intern Med $1982 ; 142: 25-27$

- Govaert ThME, Dinant GJ, Knottnerus JA. Vaccinatie tegen influenza in een huisartspraktijk. Opkomst en vaccinatie graad van risicopatiënten. Huisarts Wet 1991; 34: 478-81

- Govaert ThME, Sprenger MJW, Dinant GJ, Aretz K, Masurel N, Knottnerus JA. Immune response to influenza vaccination of elderly people: randomised double blind placebo controlled trial. Accepted for publication in Vaccine

- Govaert ThME, Thijs CTMCN, Sprenger MJW, Dinant GJ, Aretz K, Masurel N, Knottnerus JA. De effectiviteit van influenzavaccinatie bij ouderen: een gerandomiseerde, dubbelblinde, placebo gecontroleerde studie. Aangeboden

- Govaert ThME, Dinant GJ, Aretz K, Masurel N, Sprenger MJW, Knottnerus JA. Adverse reactions to influenza vaccine in elderly people: randomised double blind placebo controlled trial. Br Med J 1993; 307: 988-90

- Govaert ThME, Dinant GJ, Sprenger MJW, Aretz K, Masurel N, Knottnerus JA. De duur van influenza en influenza-achtige ziekten bij ouderen. Geaccepteerd door Huisarts Wet

- Graaf M van der, Essen GA van, Diepersloot RJA, Sprenger MJW, Masurel N. Influenzavaccinatie in de huisartspraktijk: de effecten van de voorlichtingscampagne 1992 (Aangeboden)

- Gross PA, Quinnan GV, Rodstein M, LaMontagne JR, Kaslow RA, Saah AJ, et al. Associations of influenza immunization with reduction in mortality in an elderly population. A prospective study. Arch Intern Med 1988; 148: 562-65

- Gross PA, Quinnan GV, Weksler ME, Gaerlan PF, Denning CR. Immunization of elderly people with high doses of influenza vaccine. J Am Geriatr Soc 1988; 36: 209-12

- Hammond GW, Cheang M. Absenteisme among hospital staff during an influenza epidemic: implications for immuno- prophylaxis. Can Med Assoc J 1984; 134: 449-52

- Hannoun C, Dab W, Cohen JM. A new influenza surveillance system in France: the Ile-de- France "Grog". 1. Principles and Methodology. Eur J Epidemiol 1989; 5: 285-93

- Hayden Fg, Belshe RB, Clover RD, Hay AJ, Oukes MG, Soo W. Emergence and apparent transmission of rimantadine-resistant influenza-A virus in families. New Engl J Med 1989; 321: 1696-1702

- Helliwel BE, Drummond MF. The costs and benefits of preventing influenza in Ontario's elderly. Can J Public Health 1988; 79: 175-79

- Henle W, Henle G, Stoke J. Demonstration of efficiency of vaccination against influenza type A by experimental infection of human beings. J Immun 1943; 46: 163-75

- Hobson D, Baker FA, Curry RL. Effects of influenza vaccines in stimulating antibody in volunteers with prior immunity. Lancet 1973; ii: $155-56$

- Hofstra ML, Braak EM ter, Werf G Th van der, Smith RJA. Een geautomatiseerd zoek- en oproepsysteem voor vaccinatie tegen influenza. Huisarts Wet 1990; 33: 429-32 
Höppener P, Knottnerus JA, Metsemakers JFM, Kocken RJJ, Limonard ChBG. Het Registratienet Huisartspraktijken van de Rijksuniversiteit Limburg. Een geautomatiseerd steekproefbestand voor huisartsgeneeskundig onderzoek. Huisarts. Wet 1990: 33: 66-69

- Hoskins TW, Davies JR, Smith AJ, Miller CL, Allchin A. Assessment of inactivated influenza-A vaccine after three outbreaks of influenza A at Christ's hospital. Lancet 1979; i: $33-35$

- Housworth J, Langmuir AD. Excess mortality from epidemic influenza: 1957-1966. Am J Epidemiol 1974; 100: 40-48

- Howells CHL, Vesselinova-Jenlins CK, Evans AD, James J. Influenza vaccination and mortality from bronchopneumonia in the elderly. Lancet 1975; i: $381-83$

- Jong JC de, Bartelds AIM. Verslag Nivel/RIVM pilot-studie voor de virologische surveillance van IAZ in de winter van 1991/1992. Utrecht: Nivel/RIVM; 1992

- Johnson N, Mant D, Jones L, Randall T. Use of computerised general practice data for population surveillance: comparative study of influenza data. Br Med J 1991; 302: 763-65

- Kaan JA, Masurel N, Bosschaart AN, Somsen JG. Een fatale influenza-epidemie bij een 10-jarige jongen, Ned Tijdschr Geneeskd 1993; 137: 1978-79

- Keitel WA, Cate TR, Couch RB. Efficacy of sequential annual vaccination with inactivated influenza virus vaccine. Am J Epidemiol 1988; 127: 353-64.

- Keitel WA, Couch RB, Bond N, Adair S, Nest G van, Dekker C. Pilot evaluation of influenza virus vaccine (IVV) combined with adjuvant. Vaccine 1993; 11: 909-13

- Keitel WA, Couch RB, Quarles JM, Cate TR, Baxter B, Maassab HF. Trivalent attenuated cold-adapted influenza virus vaccine: reduced viral shedding and serum antibody responses in susceptible adults. J Inf Dis 1993; 167: 305-11

- Kempen BM, Sprenger MJW. Van influenza-epidemie tot vaccinproductie. Het belang van influenza-surveillance. TGO/JDR 1992; 17: 226-29

- Keren G, Segev S, Morag A, Zakay-Rones Z, Barzilai A, Rubinstein A. Failure of influenza vaccination in the aged. J Med Virol 1988; 25: 85-89

- Kleinbaum DG, Kupper LL, Morgenstern H. Epidemiologic research. Principles and quantitative methods. London: Lifetime Learning Publications, 1982: 477-82

- Lamberts H, Wood M. International Classification of Primary Care. Oxford: Oxford University Press, 1983

- Lamberts H, Brouwer HJ, Mohrs J. Reason for encounter \& episode \& proces oriented standard output from Transitions project. Part I. Amsterdam: University of Amsterdam, 1991

- LaMontagne JR, Noble GR, Quinnan GV, Curlin GT, Blackwelder WC, Smith JI et al. Summary of clinical trials of inactivated influenza vaccine-1978. Rev Infect Dis 1983; 5: 723-36

- Langmuir AD. William Farr: Founder of modern concepts of surveillance.

Int J Epidemiol 1976; 5: 13-18

Langmuir AD. Evolution of the concept of surveillance in the United States. Proc Roy Soc Med 1971; 64: 681-84

Lui KJ, Kendal AP. Impact of influenza epidemics on mortality in the United States from October 1972 to May 1985. Am J Public Health 1987; 77: 712-16

- Margolis KL, Nichol Kl, Poland GA, Pluhar RE. Frequency of adverse reactions to influenza vaccine in the elderly. A randomised, placebo controlled trial. JAMA 1990; 264: 1139-41

- Margolis KL, Poland GA, Nichol KL, MacPherson DS, Meyer JD, Korn JE, Lofgren RP. Frequency of adverse reactions after influenza vaccination. Am J Med 1990; 88: 27-30 
- Masurel N. Relation between Hong Kong virus and former human A2 isolates and the A/Equi2 virus in human sera collected before 1957. Lancet 1969; i: 907-10

- Masurel N. Swine influenza virus and the recycling of influenza-A viruses in man. Lancet 1976; ii: $244-47$

- Masurel N, Ophof B, Jong P de. Antibody respons to immunization with influenza A/USSR/77 (H1N1) virus in young individuals primed or unprimed for A/New Jersey/76 (H1N1) virus. J Hyg Cam 1981; 87: 201-09

- Masurel N, Heijtink RA. Recycling of H1N1 influenza A virus in man- a haemagglutinin antibody study. J Hyg Cam 1983; 90: 397-402

- Masurel N, Laufer J. A one year study of trivalent influenza vaccines in primed and unprimed volunteers: immunogenicity, clinical reactions and protection.

J Hyg Cam 1984; 92: 263-76

- Masurel N. Orthomyxoviridae in: Wilterdink JB. Medische virologie, Utrecht: Boon, Scheltema en Holkema 1987

- Masurel N. Influenza in het seizoen 1991/'92; Vaccinsamenstelling voor het seizoen 1992/'93. Ned Tijdschr Geneeskd 1992; 136: 1780-83

- Masurel N, Bartels AJM, Baars AMJW. Influenza in het seizoen 1992/93; vaccinsamenstelling voor het seizoen 1993/94. Ned Tijschr Geneeskd 1993; 137: 1987-90

- Maucher JM, Gambert SR. Cost-effective analysis of influenza vaccination in the elderly. Age 1990; 13: 81-85

- McDowell I, Newll C, Rosser W. Comparison of three methods of recalling patients for influenza vaccination. Can Med Assoc J 1986; 135: 991-97

- McElhaney JE, Meneilly GS, Lechelt KE, Beattie BL, Bleackley RC. Antibody response to whole-virus and split-virus influenza vaccines in succesful ageing. Vaccine 1993; 11: $1055-60$

- Medical research council committee on influenza vaccine. Clinical trials of influenza vaccine. A progress report to the medical research council by its committee on clinical trials of influenza vaccine. Br Med J 1953; 227: 1173-77

- Members of the commission on influenza et al. A clinical evaluation of vaccination against influenza. JAMA 1944; 124: 982-85

- Metsemakers JFM, Höppener P, Knottnerus JA, Kocken RJJ, Limonard ChBG. Computerized health information in the Netherlands; a registration network of family practices. Br J Gen Pract 1992; 42: $102-06$

- Meynaar IA, Wout JW van het, Vandenbroucke JP, Furth R van. Vaccinatie tegen influenza: Aanmoedigen of afzien? Ned Tijdschr Geneeskd 1992; 136: 168-72

- Meynaar IA, Wout JW van het, Vanderbroucke JP, Furth R van. De opvattingen van huisartsen en specialisten over de vaccinatie tegen influenza. Ned Tijdschr Geneeskd 1992; 4: 176-79

- Moran WP. Nelson K, Wofford JL, Velez R. Computer-generated mailed reminders for influenza immunization: A clinical trial. J Gen Intern Med 1992; 7: 535-37

- Mostow SR, Schoenbaum SC, Dowdle WR, Coleman MT, Kaye HS, Studies with inactivated influenza vaccines purified by zonal centrifugation. I. Adverse reactions and serological response. Bull WHO 1969; 41: 525-30

- Mostow Sr, Eickhof TC, Chelgren GA, Retailiau F, Castle M. Studies of inactivated influenza virusvaccines in hospital employees: reactogenicity and absenteeism. $J$ Infect Dis. $1977 ; 136: 533-38$

- Mulder J, Masurel N, Deggars EM, Webbers PJ. Pre-epidemic antibody against 1957 strain of Asiatic influenza in serum of older people living in the Netherlands. Lancet 1958; i: 810-14

- Mullooly JP. Increasing influenza vaccination among high-risk elderly: a randomized controlled trial of a mail cue in a HMO setting. Am J Public Health 1987; 77: 626-27 
Nederlands instituut voor onderzoek van de eerstelijnsgezondheidszorg (NIVEL). Continue morbiditeits registratie peilstations Nederland. 1988/89. Utrecht: Nivel; 1991 Nerome K, Yoshioka Y, Ishida M, Okuma K, Oka T, Kataoka T, et al. Development of a new type of influenza subunit vaccine made by muramyldipeptide-liposome: enhancement of humoral and cellular immune responses. Vaccine 1990; 8: 503-09 Neurath AR, Rubin BA, Sillaman J, Tint H. The effect of nonaqueous solvents on the quaternary structure of viruses: a procedure for the simultaneous concentration, purification and disruption of influenza viruses. Microbios 1971; 4: 145-50 - Nicholson KG. Influenza vaccination and the elderly. Br Med J 1990; 301: 617-18 - Nicholson KG, Wiselka MJ, May A. Influenza vaccination of the elderly: perceptions and policies of general practitioners and outcome of the 1985-86 immunization programme in Trent, UK. Vaccine 1987; 5: 302-06

- Nickol KL, Lofgren RP, Gapinsky J. Influenza vaccinations, knowledge, attidudes and behavior among high-risk outpatients. Arch Intern Med 1992; 152: 106-10

- Pachucki CT. The diagnosis of influenza. Semin Resp Infect 1992; 7: 46-53

Palache AM. Influenza vaccination. The effect of dose and age of the antibody response [Thesis]. Rotterdam: Erasmus Universiteit Rotterdam, 1991

- Palache AM. Influenza subunit vaccine- ten years experience. Eur J Clin Research 1992; 3: $117-38$

- Palache AM, Beyer WEP, Sprenger MJW, Masurel N, Jonge S de, Vardy A, et al. Antibody response after influenza immunization with various vaccine doses: a double blind, placebo controlled, multi-centre, dose-response study in elderly nursing home residents and young volunteers. Vaccine 1993; 11: 3-9

- Palache AM, Beyer WEP, Lüchters G, Völker R, Sprenger MJW, Masurel N. Influenza vaccines: the effect of vaccine dose on antibody response in primed populations during the ongoing interpandemic period. A review of the literature. Vaccine 1993; 11: 892-908 - Parkman PD, Galasso GJ, Top FH, Noble GR. Summary of clinical trials of influenza vaccines. J Infect Dis 1976; 134: 100-07

- Patriarca PA, Weber JA, Parker RA, Hall WN, Kendal AP, Bregman DJ, Schonberger LB. Efficacy of influenza vaccine in nursing homes, reduction in illness and complications during an influenza A (H3N2) epidemic. JAMA 1985; 253: 1136-39

- Patriarca PA, Weber JA, Parker RA, Orenstein WA, Hall WN, Kendall AP, Schonberger LB. Risk factors four outbreaks of influenza in nursing homes. Am J Epidemiol 1986; 124: $114-19$

- Patterson KD, Pyle GF. The geography and mortality of the 1918 influenza pandemic. Bull Hist Med 1991; 65: 4-21

- Pel JZS. Proefonderzoek naar de frequentie en de etiologie van griepachtige ziekten in de winter 1963-1964. Huisarts Wet 1965; 8: 321-24

Polak MF. Influenza mortality in the autumm of 1957. Ned Tijdschr Geneeskd 1959; 102: 1098-109

- Potter CW, Oxford JS. Determinants of immunity to influenza infection in man. Br Med Bull 1979; 35: 69-75

Prevention and control of influenza. Recommendations of the Immunization Practice Advisory Committee. MMWR 1991; 40: 1-14

- Pyhälä R, Kleemola M. The value of complement fixation and haemagglutination inhibition tests in the diagnosis of influenza A. Acta Virol 1976; 20: 66-69

- Pyhälä R, Kinnunen L, Kumpulainen V, Ikonen N, Kleemola M, Cantell K. Influenza $\mathrm{A}(\mathrm{HINI})$ viruses in poorly primed adults under circumstances of low antigenic drift. Vaccine 1993; 11: 1013-17

- Registratienet Huisartspraktijken Rijksuniversiteit Limburg (RNH). Het gebruik van de 
ICPC lijst (International Classification of Primary Care) Maastricht: Rijksuniversiteit Limburg, 1988.

- Reimer CB. Comparision of techniques for influenza virus purification. J Bact 1966; 92 : 1271-72

- Reimer CB, Baker RS, Frank RM van, Newlin TE, Cline GB, Anderson NG. Purification of large quantities of influenza virus by density gradient centrifugation. J Virology 1967; 1: $1207-16$

- Riddough MA, Sisk JE, Bell JC. Influenza vaccination; cost-effectiveness and public policy. JAMA 1983; 249: 3189-96

- Rothbarth PhH. Antivirale therapie (1). Geneesmiddelenbull 1993; 27: 26-28

- Rothman KJ. Modern epidemiology. Boston: Little, Brown and cie, 1985: 171-73

- Ruben FL, Jackson GG. A new subunit influenza vaccine: acceptability compared with standard vaccines and effect of dose on antigenicity. J Infect Dis 1972; 125: 656-64

- Saah AJ, Neufield R, Rodstein M, LaMontagne JR, Blackwelder WC, Gross P, Quinnan $\mathrm{G}$, Kaslow RA. Influenza vaccine and pneumonia mortality in a nursing home population. Arch Int Med 1986; 146: 2263-67

- Salk JE. Reactions to concentrated influenza virus vaccines. J Immun 1948; 58: 269-95

- Scheifel DW, Bjornson G, Johnston J. Evaluation of adverse events after influenza vaccination in hospital personel. Can Med Assoc J 1990; 142: 127-30

- Schoenbaum SC, Mostow Sr, Dowdle WR, Coleman MT, Kaye HS. Studies with inactivated influenza vaccines purified by zonal centrifugation 2. Efficacy. Bull WHO 1969; 41: 531-35

- Searle SJ. Sickness absence and duration of service in the Post Office 1982-3. Br J Ind Med 1986; 43: 458-64

- Smith W, Andrewes CH, Laidlaw CH. A virus obtained from influenza patients. Lancet 1933; ii: 66-68

- Sprenger MJW, Beyer WEP, Ament AJHA, Rutten FFH, Masurel N. Influenzavaccinatie leidt tot kostenbesparing in de gezondheidszorg. Tijdschr Soc Gezondheidsz 1987; 65: $222-25$

- Sprenger MJW, Naelten van MAMG, Mulder PGH, Masurel N. Influenza mortality and excess deaths in the elderly, 1967-82. Epidem Inf 1989; 103:633-41

- Sprenger MJW. The impact of influenza: an epidemiological study of morbidity, direct mortality and related mortality [Thesis]. Rotterdam: Erasmus Universiteit Rotterdam, 1990.

- Sprenger MJW, Diepersloot RJA, Stuiver M, Postema CA, Masurel N. Influenza 1989/90: A-H3N2-Virus verwant aan het vaccinvirus. Ned Tijdschr Geneeskd 1990; 134: $663-64$

- Sprenger MJW, Diepersloot RJA, Beyer WEP, Masurel N. Influenza-related excess mortality in the Netherlands 1989/90. Lancet 1990; ii: 382

- Sprenger MJW, Mulder PGH, Beyer WEP, Strik R van, Masurel N. Impact of influenza on mortality in relation to age and underlying disease, 1967 -1989. Int J Epidemiol 1993; 22: $334-40$

- Sprenger MJW, Desmyter J, Masurel N. Minderheidsstandpunt over influenzavaccinatie bij ouderen. Ned Tijdschr Geneeskd 1991; 135: 2208-10

- Sprenger MJW, Masurel N. Influenzavaccinatie en de Postbus 5l-campagne. Ned Tijschr Geneeskd 1992; 136: 1968-70

- Stange KC, Little DW, Blatnik B. Adverse reactions to amantadine prophylaxis of influenza in a retirement home. J Am Geriatr Soc 1991; 9: 700-05

- Strassburg MA, Greenland S, Sorvillo FJ, Lieb LE, Habel LA. Influenza in the elderly: report of an outbreak and a review of vaccine effectiveness reports. Vaccine 1986; 4: 38-44 
- Stuart-Harris CH, Schild GC, Oxford JS. Influenza. The viruses and the disease, 2nd ed. London: Edward Arnold Ltd 1985

- Stuart WH, Dull HB, Newton LH, McQueen JL, Schiff ER. Evaluation on monovalentt influenza vaccine in a retirement community during the epidemic of 1965-1966, JAMA 1969; 209: 232-38

- Tellnes G. Sickness certification in general practice: a review. Fam Prac 1989; 6: 58-65

- Tellnes G. Duration of sickness certification. Scand J Prim Health Care: 1989; 7: 237-44

- Tellnes G. Days lost by sickness certification. Scan J Prim Health Care 1989; 7: 2415-51

- Tellnes G, Bjerkedal T. Epidemiology of sickness certification. A methodological approach based on a study from Buskerud county in Norway. Scan J Soc Med 1989; 17: $245-51$

- Tellnes G, Svendsen KOB, Bruusgaard D, Bjerkeldal T. Incidence of sickness certification. Proposal for use as a health status indicator. Scan J Prim Health Care 1989; 7: 111-17

- Thijs CTMCN, Knipschild PG, Leffers P. Pregnancy and gallstone disease. An empiric demonstration of the importance of specification of risk periods. Am J Epidemiol 1991; 134: $186-95$

- Vanghan WT. Influenza- an epidemiology study. Am J Hyg, Monograph 1921; 1:1

- Veen WA van. Influenzavaccinatie: hoe effectief is het beleid? Huisarts Wet 1990; 33: 415-16

- Velden J van den, Bakker DH de, Claessens AAMC, Schellevis FG. Een nationale studie naar ziekten en verrichtingen in de huisartspraktijk. Basisrapport: Morbiditeit in de huisartspraktijk. Utrecht: NIVEL, 1991

- Voth DW, Feldman HA, Steinschneider A. Comparative responses of elderly persons to aqueous and depot influenza vaccines. Arch Environ Health 1966; 13: 576-85

- Weingarte S, Staniloff H, Ault M, Miles P, Bamberger M, Meyer R. Do hospital employees benefit from the influenza vaccine? J Gen Int Med 1988; 3: 31-37 


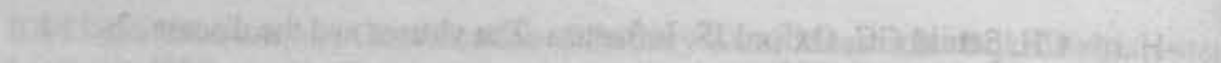

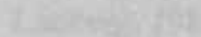

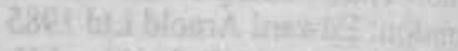

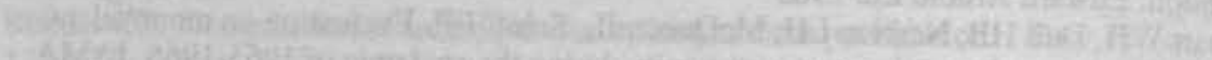

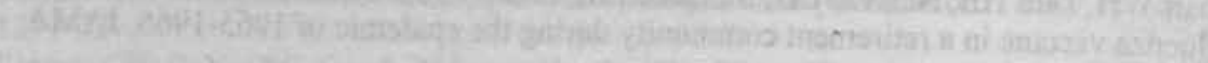

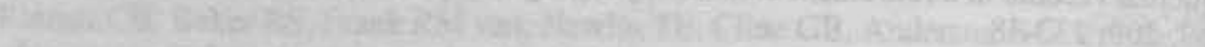

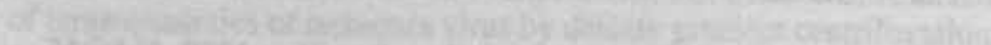

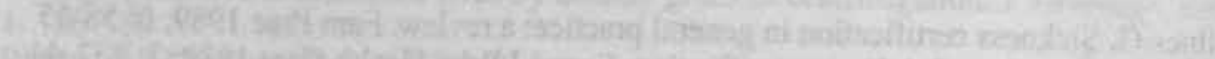

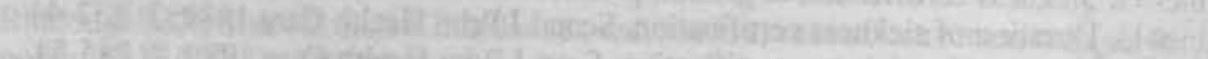

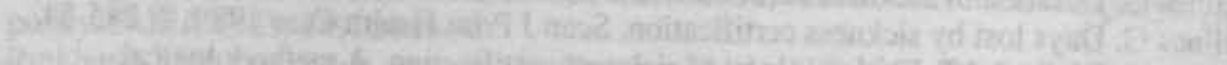

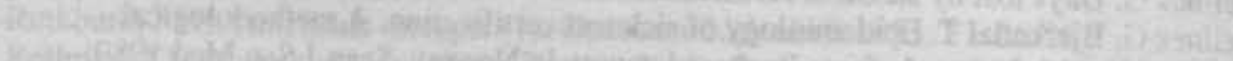

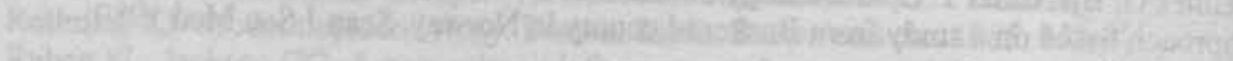

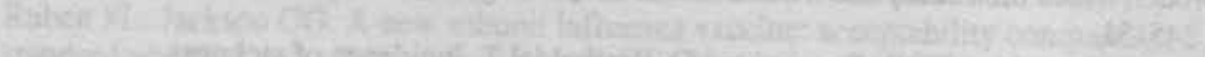

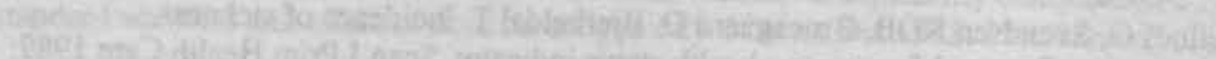

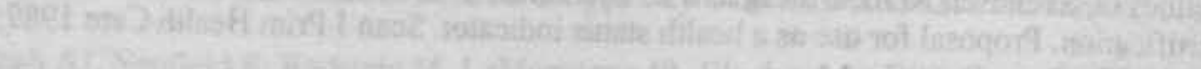

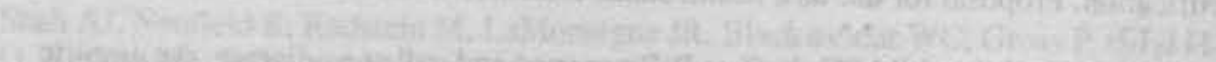

W.

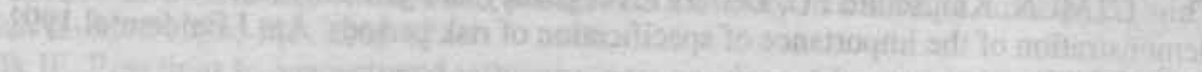

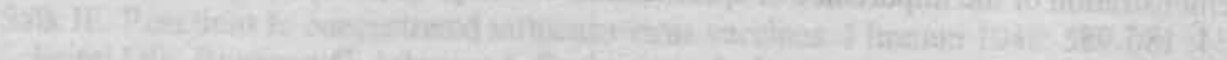

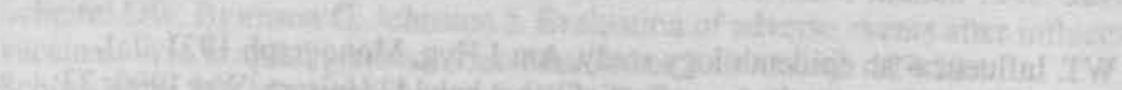

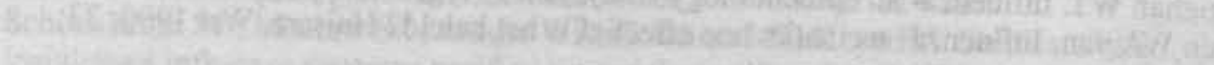

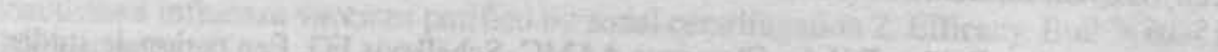

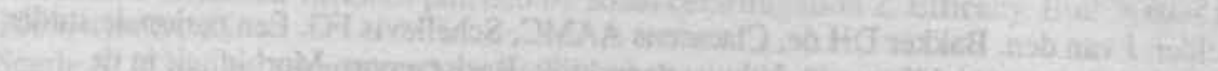

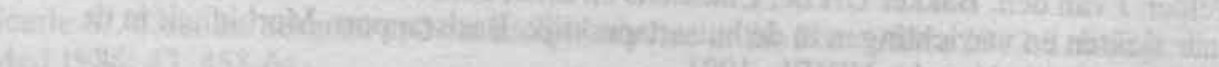

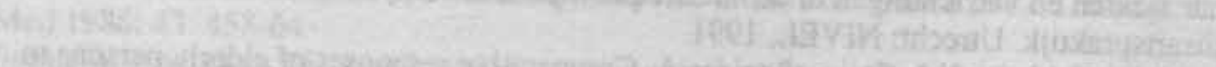

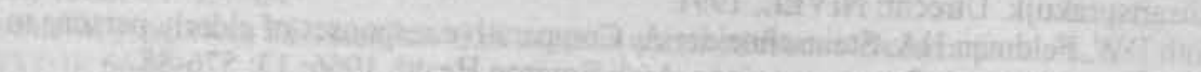

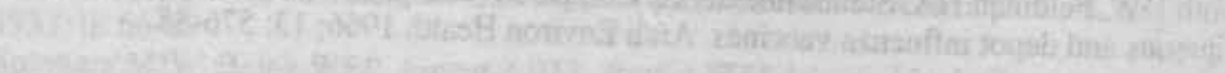

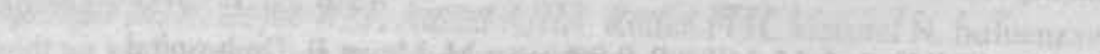

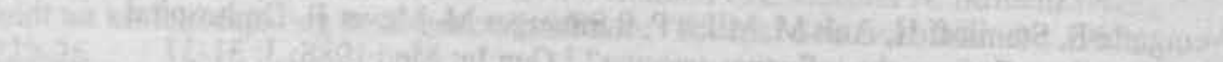

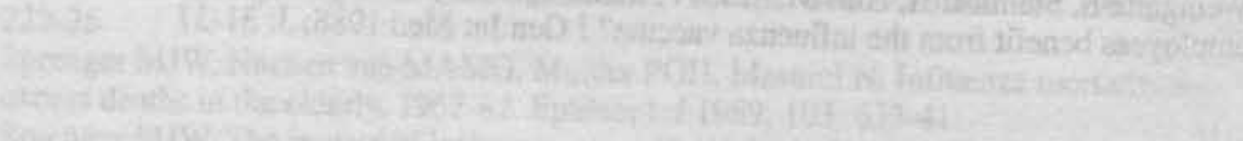

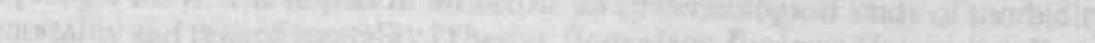
than

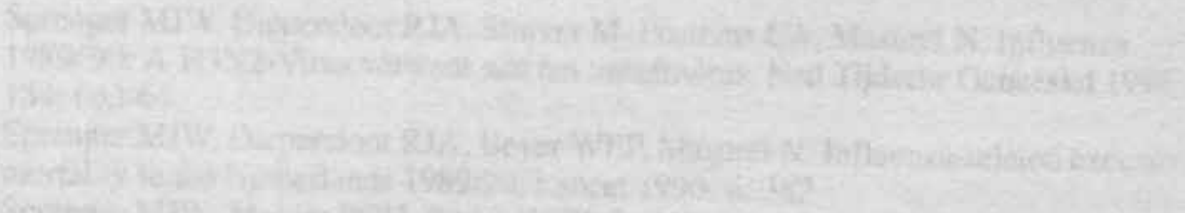

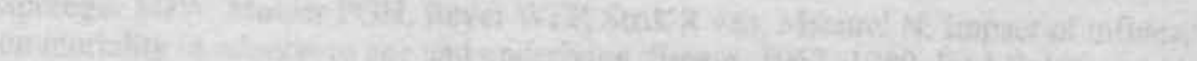

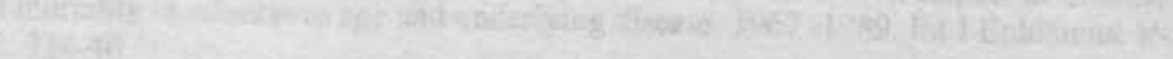

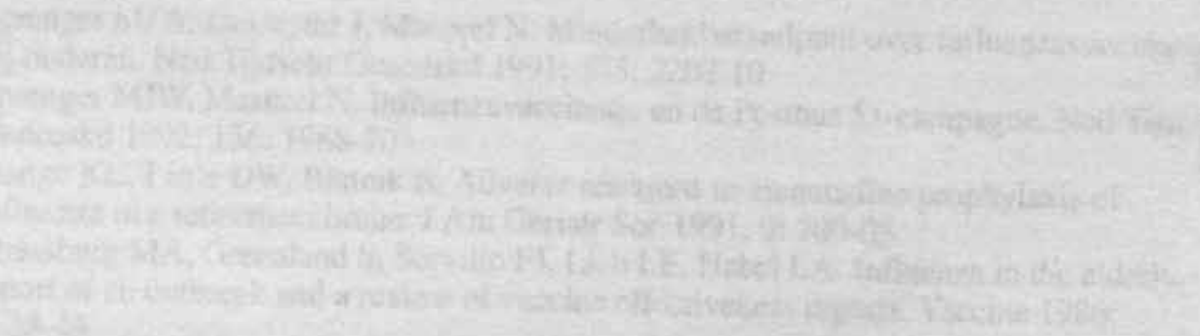




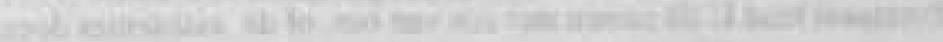

\section{BIJLAGEN}




\section{Bijlage 3.1}

\section{Vragenlijst}

Wilt $U$ a.u.b. omcirkelen wat voor $U$ het goede antwoord is.

Eventueel kunt $U$ dit samen met een van ons, of de assistentes doen.

1 Werd U plotseling ziek

2 Hebt U moeten hoesten

3 Hebt U koude rillingen gehad

4 Hebt U koorts gehad

5 Hebt U zich ziek gevoeld

6 Hebt U hoofdpijn gehad

7 Hebt $U$ pijn in armen of of benen gehad

8 Hebt U keelpijn gehad

9 Hebt U een loopneus gehad

10 Hebt $\mathrm{U}$ dunne ontlasting gehad

11 Hebt U buikpijn gehad

12 Hoeveel dagen bent $\mathrm{U}$ ziek geweest.

13 Wanneer hebt $U$ uw werk (of andere bezigheden zoals huishouden, hobby's) weer kunnen hervatten....... nee

nee

nee

nee

nee

nee

nee

nee

nee

ja nee

ja nee

aantal dagen 
De verschillende stappen in dit onderzoek zijn in de volgende tijdbalk weergegeven

Oktober 1989 - April 1991: vóóronderzoek in eigen praktijk

December 1990

* Aanvraag subsidie Praeventiefonds

* Aanvraag onderzoekvoorstel bij Medisch

Ethische Commissie

Mei 1991

* goedkeuring onderzoekvoorstel door het Bestuur van het Praeventiefonds

\section{Augustus 1991}

* toezenden vragenlijst aan patiënten die informed consent ondertekend hebben

\section{Oktober 1991}

* verzenden oproep brief voor eerste en tweede ronde bloedafname en vaccinatie

* Bereiding vaccin/ placebo dagelijks vanaf 31 okt.'91

\section{Maart 1992}

* verzenden oproepbrief voor derde ronde bloedafname

\author{
Maart 1991 \\ * goedkeuring \\ onderzoekvoorstel \\ door Medisch Ethische \\ Commissie
}

\author{
April 1991 \\ * overieg met \\ deelnemende \\ huisartsen
}
Mei-Juni 1991
* selectie uit basis populatie volgens in- en exclusie criteria
Juli 1991
* uitnodiging potentiële deelnemers
* informed consent

September 1991

* contrôle lijsten van aspirant deelnemers door huisartsen

\section{Nov.-6 Dec.1991}

* eerste twee rondes bloedafname en vaccinatie

* verwerking bloedmonsters (dagelijks)

* bereiding vaccin/ placebo (dagelijks tot 15 nov.'91)

\section{1-15 April 1992 \\ * laatste ronde bloedafname \\ * verwerken bloed- monsters (dagelijks)}

\section{Oktober 1991}

* prestratificatie

* randomisatie

November 1992 - November 1993: data-analyse en verslaglegging 


\section{Briefhoofd huisarts(en).}

Juli 1991

\section{Geachte Mevrouw, Heer}

Griep is een vervelende ziekte. Ieder jaar is menigeen er ziek van. In november worden veel mensen in verband met hun gezondheidstoestand ingeënt tegen griep. Toch weet men nog steeds niet of deze inentingen voldoende resultaten opleveren. Hiermee wordt bedoeld: krijgen mensen die gevaccineerd worden tegen griep duidelijk minder gauw griep of zijn ze minder erg ziek van griep?

Samen met de Universiteit van Maastricht willen wij het nut van deze inentingen onderzoeken. Dit onderzoek houdt in dat het aantal deelnemers aan het onderzoek wordt verdeeld in twee groepen: een helft van de deelnemers krijgt een griepspuit, de andere helft van de deelnemers krijgt een spuit waarin geen werkzame stof zit. Zowel de arts als de patiënt weten niet welke spuit de deelnemer aan het onderzoek krijgt. Op deze manier is een onderzoek naar de werkzaamheid van een medicament betrouwbaar. Van alle deelnemers wordt tevens driemaal een weinig bloed uit de arm genomen; tweemaal in november 1991 en eenmaal enkele maanden later. Dit bloed gaan we onderzoeken om te kunnen zien of zich hierin het griepvirus of mogelijk een andere ziekteveroorzaker bevindt. Het onderzoek vindt plaats in de praktijk van uw eigen huisarts.

Voor het slagen van het onderzoek is het belangrijk dat zoveel mogelijk patiënten voor wie het van belang is het nut van een vaccinatie vast te stellen mee doen. Wij vragen U vriendelijk of $U$ aan dit onderzoek wilt deelnemen. Wanneer $U$ bereid bent hieraan mee te doen krijgt $U$ in oktober 1991 een oproep hiervoor. Aan de deelnemers die volledig aan het onderzoek hebben deelgenomen wordt bij de laatste bloedafname een bedrag van $f$ 60,uitgekeerd. U bent volledig vrij in de keuze om aan het onderzoek deel te nemen. Gedurende het onderzoek kunnen zich omstandigheden voordoen waardoor $U$ niet meer mee kunt doen; ook dan bent $U$ vrij om ermee te stoppen. Mocht $U$ nog inlichtingen willen hebben dan kunt $U$ altijd terecht bij uw huisarts of diens assistentes.

Wilt $U$ het bijgevoegde antwoordformulier invullen en per post versturen (postzegel is niet nodig) of in de praktijk afgeven.

Indien $U$ niet meedoet wilt $U$ dan toch zo vriendelijk zijn deze kaart ingevuld terug te sturen.

Met dank voor de te nemen moeite.

Naam huisarts(en).

Th.M.E. Govaert

huisarts-onderzoeker

Prof.dr J.A. Knottnerus

Hoogleraar huisartsgeneeskunde 
Bijlage 5.4.1

Antwoordformulier

Ondergetekende verklaart hierbij WEL / NIET (doorstrepen wat niet van toepassing is) mee te willen werken aan het onderzoek naar het effect van griepvaccinatie zoals beschreven in de brief van juni 1991.

Naam

Geboortedatum

Adres

Plaats

code.

Handtekening

N.B. Gelieve in ieder geval antwoord te geven. 
Geachte heer, mevrouw,

Hartelijk dank voor uw bereidheid om deel te nemen aan het onderzoek naar de waarde van de griepinenting.

Wij zullen U op de hoogte houden van elke stap in het onderzoek.

Voor alle vragen en/of problemen kunt U terecht bij de onderzoeker (dkt. Govaert, tel. 046331212), of bij uw eigen huisarts.

Om na te gaan of wij beschikken over de juiste gegevens, willen wij U vriendelijk verzoeken om de ingesloten vragenlijst in te vullen. U kunt de lijst in de bijgevoegde antwoordenveloppe terugsturen, of in de praktijk van uw huisarts afgeven. Een postzegel is niet nodig. Indien U problemen heeft met het beantwoorden van de vragen, kunt $U$ bij uw huisarts terecht voor hulp. De gegevens worden anoniem verwerkt, dat wil zeggen zonder uw naam en adres.

Voor de duidelijkheid vermelden wij nog eens dat het onderzoek plaats vindt met medewerking van uw eigen huisarts, in samenwerking met de Rijksuniversiteit Limburg.

Het onderzoek vindt dan ook plaats in de praktijk van uw huisarts. Half oktober 1991 ontvangt $U$ van ons bericht wanneer $U$ in de praktijk verwacht wordt voor de griepprik en voor afname van wat bloed.

Wilt $U$ zo vriendelijk zijn deze vragenlijst binnen 14 dagen aan ons terug te sturen. Mede namens uw huisarts hartelijk dank voor uw medewerking.

Met vriendelijke groeten,

Th.M.E. Govaert, huisarts-onderzoeker 
Bijlage 5.4.3

\section{VRAGENLUST}

1 Zijn uw persoonsgegevens op het etiket juist? $\quad 0$ ja (naam, adres enz.)

$\mathrm{O}$ nee

Wilt u zonodig hieronder de juiste gegevens vermelden:

Naam en voorletters

Straat en huisnummer

Postcode en plaats

2 Wat is uw telefoonnummer

(Ook invullen indien u een geheim nummer heeft. Het nummer blijft strikt geheim).

3 Bent u in 1989 ingeënt tegen griep?

O ja

$\mathrm{O}$ nee

4 Bent u in 1990 ingeënt tegen griep?

O ja

$O$ nee

5 Is een van uw huisgenoten in 1989 ingeënt tegen griep?

O ja

O nee

6 Is een van uw huisgenoten in 1990 ingeënt tegen griep?

O ja

$O$ nee

7 Heeft $U$ ziekten of aandoeningen van de longen? (zoals b.v. bronchitis, emphyseem, stoflongen, pleuritis, klaplong). zo ja, welke

8 Heeft U ziekten of aandoeningen van het hart of bloedvatenstelsel? (zoals b.v.hartinfarct, onregelmatige hartslag, angina, beroerte)

O ja

0 nee zo ja, welke.

9 Heeft U suikerziekte (diabetes mellitus)?

O ja

0 nee

O ja

0 nee

10 Heeft U een aandoening van de schildklier?

O ja

O nee zo ja, welke

Wilt $U$ deze vragenlijst in bijgevoegde enveloppe terugsturen of in de praktijk van uw huisarts afgeven? 
Geachte meneer, mevrouw,

U wordt voor deelname aan het grieponderzoek in totaal 3 keer verwacht in de praktijk van uw huisarts.

Twee keer in november ' 91 en een keer in april ' 92.

De data voor november ' 91 staan vermeld op het bijgevoegde gele kaartje. Dit kaartje moet $\mathrm{u}$ steeds meenemen wanneer u komt voor het onderzoek.

De datum in april ' 92 wordt $u$ nog nader meegedeeld.

Indien u op de vermelde tijdstippen niet kunt komen, dan verzoeken wij u tijdig contact op te nemen met de onderzoekassistente Karin Aretz, tel. 043-882230 of bij geen gehoor 046332958 (Mevr. H. Govaert).

Wij danken u mede namens uw huisarts nogmaals voor uw bereidwilligheid om aan dit onderzoek deel te nemen.

Met vriendelijke groet,

Th.M.E. Govaert, huisarts-onderzoeker, Prof. dr J.A. Knottnerus, hoogleraar Huisartsgeneeskunde

Naam: huisarts(en),

Naam

Adres

pat. no

le Afspraak

Datum:

Tijd:

Vrijdag 1 november 1991

19.20 uur

pat.no.

2e Afspraak

Datum:

Tijd :

Vrijdag 22 november 1991

19.20 uur 
Geachte heer, mevrouw,

Ingesloten vindt $\mathrm{u}$ een gele afspraakkaart voor de laatste bloedafname van het grieponderzoek. Op deze kaart staat vermeld datum en tijdstip waarop u verwacht wordt in de praktijk van uw eigen huisarts. Indien u een van de vorige keren in een andere praktijk geprikt bent, wordt $\mathrm{u}$ nu toch verwacht in de praktijk van uw eigen huisarts.

Wilt u deze afspraakkaart meenemen. Hierop moet uw handtekening gezet worden als bewijs van ontvangst van $f 60$, ter attentie voor uw deelname aan het onderzoek. Wilt u ook niet vergeten de nog in uw bezit zijnde vragenlijst(en), die nog niet zijn opgestuurd, mee te nemen.

Mogen wij in het belang van het onderzoek een ieder vragen ook aan deze laatste oproep gehoor te geven. Indien u op het vermelde tijdstip niet kunt komen verzoeken wij u tijdig contact op te nemen met mevrouw H. Govaert, tel. 046-332958. Sommige deelnemers hebben gevraagd wanneer de resultaten van dit onderzoek bekend gemaakt worden. Tot mijn spijt moet ik u mededelen dat dit nog heel wat tijd vergt. Het verzamelde bloed (ongeveer 5600 buisjes) wordt in het Influenza Centrum te Rotterdam onderzocht. Dit duurt ongeveer 5 maanden. Daarna moeten de verkregen gegevens door ons bewerkt worden. Hetgeen ook nog de nodige maanden in beslag zal nemen. Zodra de resultaten hiervan bekend zijn zullen wij u een korte samenvatting sturen.

Wel is het voor u misschien nu al interessant te weten dat van het oorspronkelijke aantal opgeroepen patiënten, 1889 in totaal, in de eerste ronde 1838 en in de tweede ronde 1824 patiënten verschenen. Dit is een bijzondere mooie opkomst. Wij hopen dat deze laatste ronde ook zo'n goede opkomst oplevert.

Mag ik u, ook namens de andere projectmedewerkers, heel hartelijk danken voor uw deelname

Met vriendelijke groeten, mede namens uw huisarts,

Th.M.E. Govaert

huisarts-onderzoeker
Prof. dr J.A. Knottnerus

Hoogleraar huisartsgeneeskunde. 
Bijlage 5.7.3

Tijdschema Grieponderzoek

\begin{tabular}{|c|c|c|c|c|c|c|}
\hline Datum & Team & Praktijk (no) & Tijden & Aantal & Totaal & Lab.Tijd \\
\hline I vrijd 1 nov. & $\begin{array}{l}\mathrm{A} \\
\mathrm{B}\end{array}$ & & $\begin{array}{l}15.00-19.30 u \\
18.00-19.30 u\end{array}$ & $\begin{array}{r}108 \\
36\end{array}$ & 144 & 7.u \\
\hline II vrijd 22 nov. & zelfde & schema & 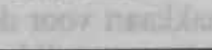 & nowis & $\operatorname{sen} 16$ & \\
\hline
\end{tabular}

I maand.4 nov.

$\begin{array}{rrrr}\text { A } & 1 & 15.00-19.30 \mathrm{u} & 108 \\ \text { B } & 11 & 15.00-17.00 \mathrm{u} & 48 \\ \text { B } & 1 & 18.00-19.30 \mathrm{u} & 36\end{array}$

II maand. 25 nov. zelfde schema

$\begin{array}{llll}18.00-19.30 u & 36 & 192 & 9.30 u\end{array}$

\begin{tabular}{llllllll}
\hline I dinsd.5 nov. & A & 1 & $15.30-19.30 \mathrm{u}$ & 88 & & \\
& B & 1 & $15.30-17.00 \mathrm{u}$ & 36 & & \\
II dinsd.26 nov & B & 11 & $18.00-19.30 \mathrm{u}$ & 35 & 159 & $8 . \mathrm{u}$ \\
\hline I woens.6 nov. & zelfde schema & & & & & \\
\hline & A: 15 & 15 & $15.00-19.00 \mathrm{u}$ & 96 & & \\
II woensd 27nov. & B: 13 & 12 & $15.00-16.20 \mathrm{u}$ & 31 & & \\
zelfde schema & $17.30-19.45 \mathrm{u}$ & 52 & 179 & $9 . \mathrm{u}$ \\
\hline
\end{tabular}

I dond. 7 nov.

$\begin{array}{llll}\text { A: } & 15 & 15.00-16.40 \mathrm{u} & 39 \\ \text { A: } & 12 & 17.30-19.30 \mathrm{u} & 48 \\ \text { B: } & 13 & 15.00-19.00 \mathrm{u} & 96\end{array}$

II dond 28 nov. zelfde schema

I vrijd. 8 nov.

$\begin{array}{lr}\text { A: } & 9 \\ \text { B: } & 10\end{array}$

II vrijd. 29nov. zelfde schema

I maand.11nov.

$\begin{array}{ll}\text { A: } & 3 \\ \text { A: } & 2 \\ \text { B: } & 5\end{array}$

II maand. 2 dec. zelfde schema

I dinsd. 12 nov. $\quad$ A: 4

B: $\quad 5$

$15.00-19.10 \mathrm{u} \quad 100$

$15.00-19.00 \mathrm{u} \quad 93 \quad 193 \quad 9.40 \mathrm{u}$.

II dinsd. 3 dec. $\quad$ B: $\quad \begin{gathered}\quad 5 \\ \text { zelfde schema }\end{gathered}$

I woens. 13 nov. A: 6

$\begin{array}{lll}\text { I woens. } 13 \text { nov. } & \text { A: } & 6 \\ & \text { B: } & 6\end{array}$

II woens. 4 dec. zelfde schema

I dond. 14 nov. A: 14

B: 14

II dond. 5 dec. zelfde schema

$\begin{array}{lllll}15.00-16.15 u & 29 & & \\ 17.00-19.30 u & 57 & & \\ 15.00-19.00 u & 96 & 182 & 9 . u\end{array}$


Vervolg Tijdschema Grieponderzoek

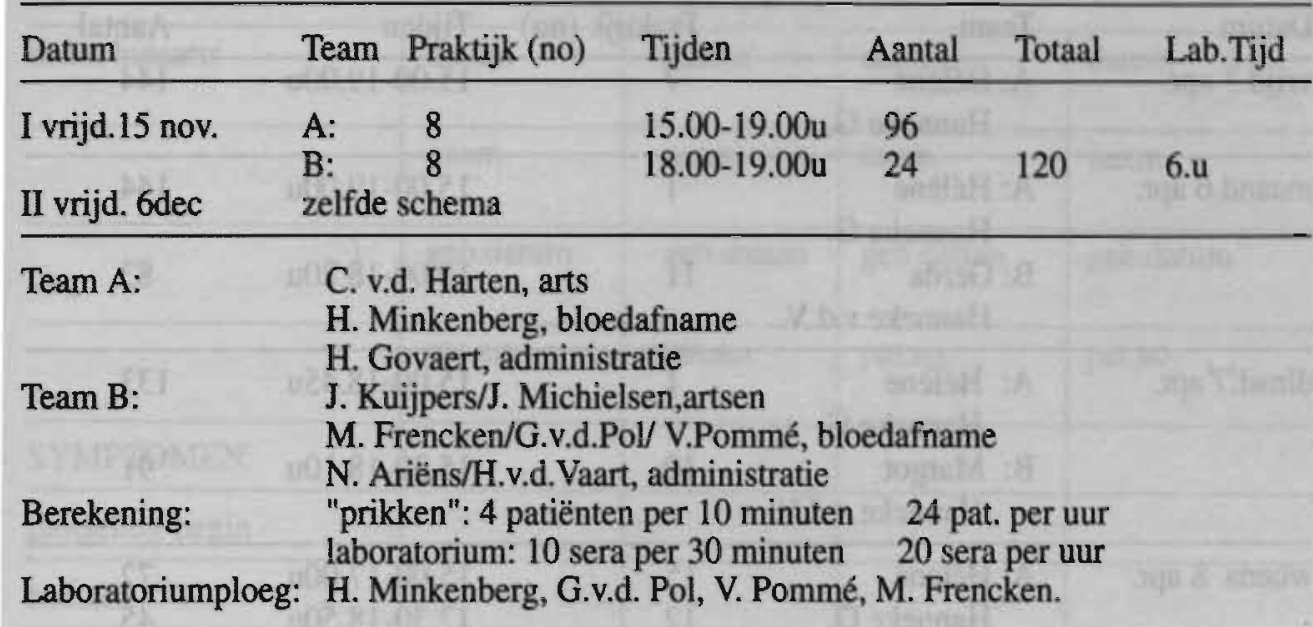


Bijlage 5.7.4

Tijdschema Grieponderzoek

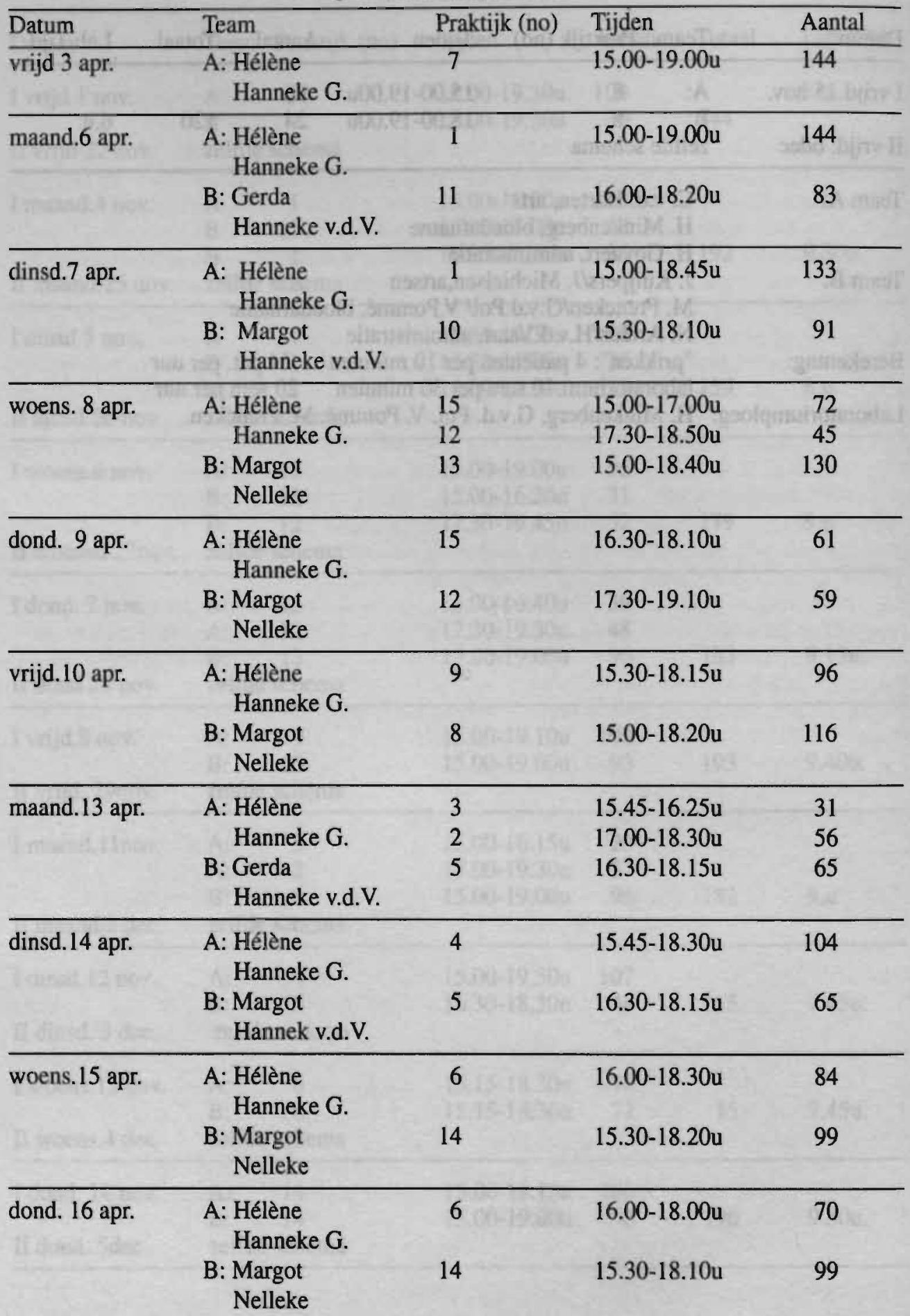


Bijlage 5.10.1

\begin{tabular}{l|l|l|l|l}
\hline \multicolumn{5}{c|}{ SYMPTOMENLIIST } \\
\hline naam huisarts & datum & datum & datum & datum \\
\hline & naam & naam & naam & naam \\
\hline SYMPTOMEN: & geb.datum & geb.datum & geb.datum & geb.datum \\
\hline plotseling begin & pat.no. & pat.no. & pat.no. & pat.no. \\
\hline hoesten & & & & \\
\hline koude rillingen & & & & \\
\hline koorts & & & & \\
\hline algemene malaise & & & & \\
\hline hoofdpijn & & & & \\
\hline myalgieën & & & & \\
\hline keelpijn & & & & \\
\hline rhinitis & & & & \\
\hline retrosternale pijn & & & & \\
\hline geel-groen sputum & & & & \\
\hline contact met influenza & & & & \\
\hline COMPLICATIES: & & & & \\
\hline dd. & & & & \\
\hline dd. & & & & \\
\hline
\end{tabular}


Geachte heer, mevrouw,

Omdat u dit jaar meedoet aan het "griep-onderzoek" heeft u een aantal weken geleden een spuit ontvangen.

Ten behoeve van dit onderzoek willen wij u een aantal vragen stellen. Wij verzoeken u vriendelijk de bijgevoegde lijst in te vullen en in de retourenveloppe terug te sturen (een postzegel is niet nodig).

De vragen gaan alleen over de periode van 1 november 1991 tot 1 januari 1992. Indien u moeite heeft met het beantwoorden van de vragen, vraag dan uw huisarts of zijn assistente om hulp.

De kans bestaat dat u in de periode van 1 november 1991 tot 1 januari 1992 vaker dan éen keer griep gehad heeft.

De bedoeling is dan dat u voor iedere "griepperiode" een vragenlijst invult. Indien u meer dan éen vragenlijst nodig heeft, dus indien u vaker dan éen keer griep gehad heeft, kunt u dit telefonisch doorgeven aan mevrouw K. Aretz, tel. 043-882230 of aan mevrouw H. Govaert tel. 046-332958.

Binnenkort zullen wij u nogmaals een vragenlijst toesturen waarin het zal gaan over de periode na 1 januari 1992.

Met vriendelijke groeten

Th. M.E. Govaert, huisarts-onderzoeker 


\section{Bijlage 5.11.2}

Indien $\mathrm{u}$ in de afgelopen periode een of meerdere malen een ziekte gehad heeft die op griep leek, wilt u dan alle vragen beantwoorden.

Indien dit niet zo is kunt u doorgaan met vraag 11.

I Wanneer heeft u griep gehad?

van tot

2 Hoelang heeft deze periode geduurd? dagen

$3 \mathrm{Na}$ hoeveel dagen heeft $\mathrm{u}$ uw werk (of andere bezigheden zoals huishouden, hobby's) weer kunnen hervatten. dagen

Ging deze griepachtige ziekte gepaard met:

4 Hoge koorts d.w.z. meer dan 38 graden rectaal ( = van achteren) gemeten

$0 \mathrm{ja} \quad 0$ nee

5 Algeheel ziek gevoel

$0 \mathrm{ja} \quad 0$ nee

6 Spierpijn (pijn in armen en benen)

$0 \mathrm{ja} \quad 0$ nee

7 Koude rillingen

$0 \mathrm{ja} \quad 0$ nee

8 Hoofdpijn

0 ja 0 nee

9 Keelpijn

$0 \mathrm{ja} \quad 0$ nee

10 Hoesten (duidelijk meer dan normaal)

$0 \mathrm{ja} \quad 0$ nee

11 Heeft u nog bijwerkingen van de griepspuit gehad gedurende de eerste twee dagen na de injectie. Zo ja, heeft $u$ op de plaats van de injectie gehad:
a) een zwelling
b) jeuk
c) warmte
d) pijn alleen bij aanraking
e) steeds pijn
f) belemmering bij gebruik van de arm

$0 \mathrm{ja} \quad 0$ nee

$0 \mathrm{ja} \quad 0$ nee

$0 \mathrm{ja} \quad 0$ nee

$0 \mathrm{ja} \quad 0$ nee

$0 \mathrm{ja} \quad 0$ nee

$0 \mathrm{ja} \quad 0$ nee

$0 \mathrm{ja} \quad 0$ nee

Heeft u ten gevolge van de vaccinatie(spuit) gehad:
a) koorts
b) hoofdpijn
c) gevoel van ziek zijn
d) andere verschijnselen
0 ja $\quad 0$ nee
$0 \mathrm{ja} \quad 0$ nee
$0 \mathrm{ja} \quad 0$ nee
$0 \mathrm{ja} \quad 0$ nee

zo ja, welke

Deze lijst binnen 2 weken terugsturen in bijgevoegde enveloppe. 
Maastricht 10 januari 1992

Geachte heer, mevrouw,

Rond de kerstdagen hebt u als de deelnemer aan het "griep onderzoek" een eerste vragenlijst ontvangen. Inmiddels zijn de meeste lijsten teruggestuurd. Willen zij die dit vergeten zijn dit alsnog doen.

U ontvangt nu een tweede vragenlijst. De opzet is nu iets anders.

De bedoeling is dat u nu vanaf 1 januari 1992 voor iedere keer dat u griep heeft een vragenlijst invult en in de retourenveloppe terug stuurt (een postzegel is niet nodig). Zodra wij een ingevulde lijst hebben ontvangen sturen wij u een nieuwe vragenlijst. Deze hoeft u pas weer in te vullen indien u onverhoopt nog eens "griep" zou krijgen.

De tweede periode duurt van 1 januari 1992 tot de datum van de laatste bloedafname.

Indien u geen griep krijgt gedurende de onderzoekperiode verzoeken wij u deze vragenlijst af te geven bij de laatste bloedafname ronde.

De beantwoording der vragen geschiedt door het juiste antwoord aan te kruisen. Voorbeeld: heeft een week 7 dagen? 0 ja $O$ nee Indien u moeite heeft met het beantwoorden van de vragen kunt $\mathrm{u}$ uw huisarts of zijn assistente om hulp vragen. Zijn er andere problemen dan kunt u telefonisch contact opnemen met mevrouw K.Aretz, tel. 043-882230 of mevrouw H.Govaert, tel 046-332958.

Met vriendelijke groeten

Th.M.E. Govaert, huisarts-onderzoeker. 


\section{ETIKET \\ patiënt}

\section{Vragenlijst}

Indien $\mathrm{u}$ in de periode vanaf 1 januari 1992 een ziekte heeft die op griep lijkt wilt $\mathrm{u}$ dan alle vragen beantwoorden door het juiste antwoord aan te kruisen.

1 Wanneer heeft u griep gehad?

2 Hoelang heeft deze periode geduurd?

3 Na hoeveel dagen heeft $\mathrm{u}$ uw werk (of andere bezigheden zoals huishouden, hobby's) weer kunnen hervatten?

Ging deze griepachtige ziekte gepaard met:

4 Hoge koorts d.w.z. meer dan 38 graden rectaal ( = van achteren) gemeten

5 Algeheel ziek gevoel

6 Spierpijn (pijn in armen en benen)

7 Koude rillingen

8 Hoofdpijn

9 Keelpijn

10 Hoesten (duidelijk meer dan normaal) van ..... tot ..... dagen dagen

O ja

O nee

O ja $\quad$ nee

$\mathrm{O}$ ja

O nee

O ja O nee

O ja O nee

O ja $\quad O$ nee

O ja $\quad O$ nee 


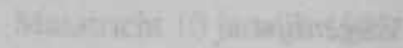

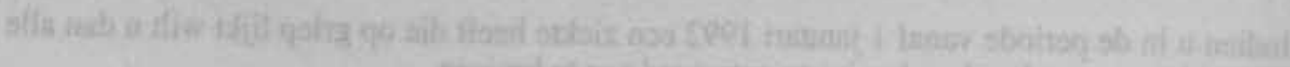

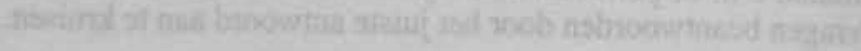

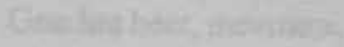

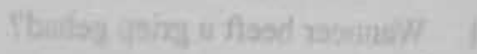

itsights

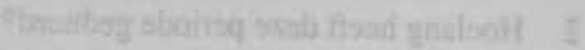

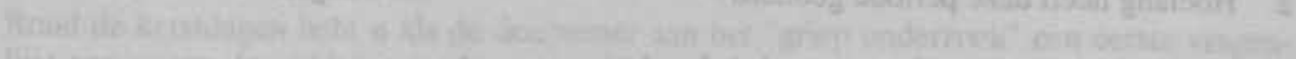

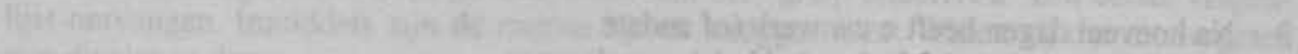

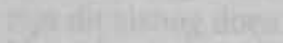

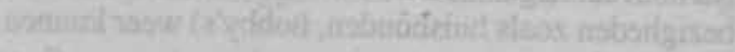

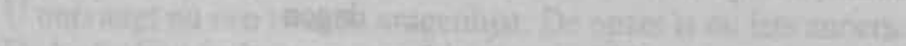

Shoingnist

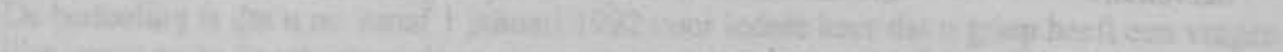

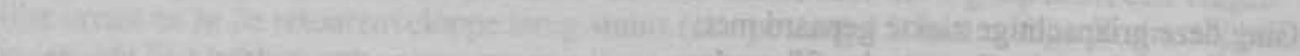

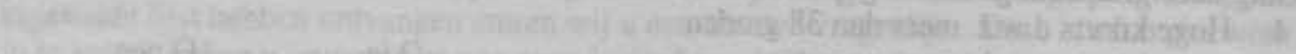

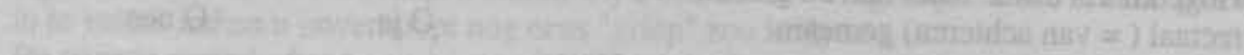

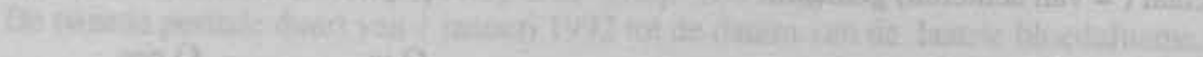
$\tan 0=\sin$

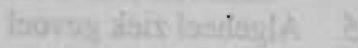

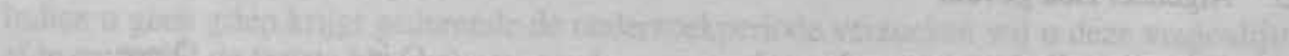

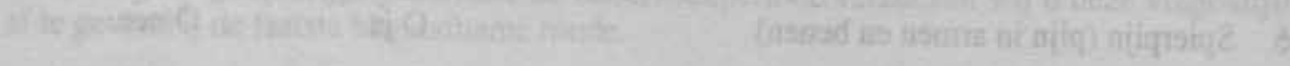

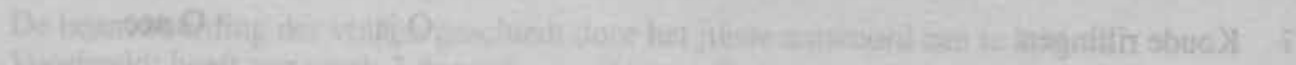

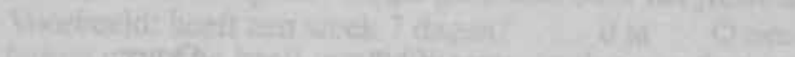

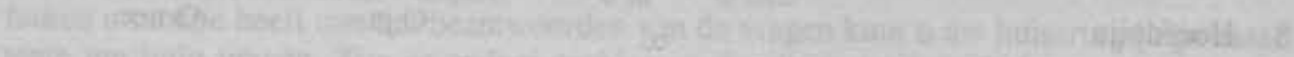

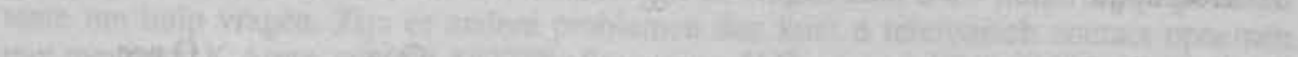

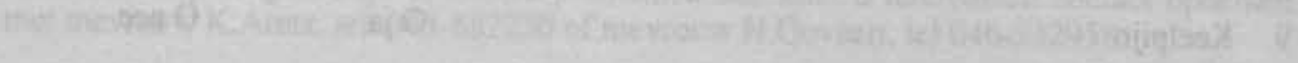

$729+2=29$

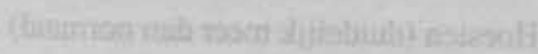

vis

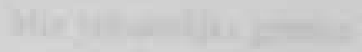




\section{DANKWOORD}

Op deze plaats past een woord van welgemeende dank aan allen die hebben meegewerkt aan de realisatie van dit onderzoek. Allereerst de 1838 deelnemers, die door hun trouwe opkomst (een uitval van slechts 1,2\%) er voor zorgden dat dit onderzoek kon slagen. Menig onderzoeker zou wensen over een dergelijke onderzoekpopulatie te mogen beschikken. De huisartsen en hun assistentes hebben in de aanloopperiode van het onderzoek regelmatig onder druk gestaan. De vorm van dit onderzoek kon dit niet voorkomen. Een ieder heeft op zijn manier zijn steentje bijgedragen. Zo ook de medewerkers van mijn eigen praktijk die mij in deze jaren gesteund hebben.

Raymond, jij hebt met name er voor gezorgd dat de gezondheidszorg in de praktijk vlekkeloos verliep. Ondanks het feit dat een extra arts aanwezig was heb jij de verantwoordelijkheid voor de praktijkvoering, die tot aan de start van het onderzoek door ons tweeën gedeeld werd, grotendeels op je schouders genomen. Voor je loyaliteit in deze ben ik jou en Rose zeer erkentelijk. Het is te merken dat onze associatie steunt op meer dan twintig jaar oude fundamenten. De wijze waarop jij in recordtempo zorgvuldig het manuscript op enkele punten stylistisch hebt weten te verfraaien getuigt van je grote belezenheid en nauwgezetheid. Van nu af aan ben ik weer $100 \%$ aanwezig.

Saskia, die bij afwezigheid van de "oude" dokter zijn aandeel in de praktijk waarnam, wist met haar sterke betrokkenheid de patiënten kundig tevreden te stellen. Ook onze praktijkassistentes Bep, Henriëtte en Bianca hebben op voorbeeldige wijze hun steentje bijgedragen. Soms was het geen sinicure mijn onderzoekdag daadwerkelijk vrij te houden. Tijdens de start van het onclerzoek hebben jullie, evenals de assistentes uit de andere deelnemende praktijken, potentiële deelnemers aan het onderzoek uitstekend te woord gestaan.

Hubert Schouten kwam als een duveltje uit het doosje op het juiste moment zijn statistische kennis etaleren. Terecht merkte hij bij onze eerste ontmoeting op dat statistisch inzicht voor een dergelijk onderzoek wel degelijk nodig was. Carla Frederiks en Jan-Willem de Jonge gaven in de beginfase waardevolle adviezen. Trudy Seegers en Paul Höppener verzorgden voor de eigenlijke start van het onderzoek op voortreffelijke wijze enige computerprogramma's.

Dank zij Piet Janson en Liesel Nohlmans-Paulssen kregen wij alle faciliteiten aangeboden om de bloedmonsters (bijna 6000) op het bacteriologisch/virologisch laboratorium van het Maaslandziekenhuis te Sittard te verwerken. De analisten van dit laboratorium waren ten alle tijden bereid extra bloedmonsters te verwerken. Onze twee "prikploegen" te weten Gerda, Hanneke V, Hanneke G, Hélène, Margot, Nelleke, Veronique en de artsen Camille, Jacques $\mathrm{K}$ en Jacques $\mathrm{M}$ hebben voorbeeldig werk geleverd. De driemaal 2 weken van 
bloedafname, 2000 vaccinaties, en nog eens 6000 serummonsters invriezen zonder één wanklank, werd besloten met een magnum champagne, aangeboden door de directie van Pharmachemie BV.

In een adem wil ik hierbij vermelden Hub en Paul, onze apothekers. Gezamelijk hebben we de eerste twee weken van het onderzoek de vaccins en placebo's tot vaak diep in de nacht klaar gemaakt voor onze prikploegen, gerandomiseerd, voorzien van vlaggetjes met identificatie-nummers, gestoken in piepschuimplateau's. Hub van jouw handigheid, kennis van het computergebeuren en "geritsel" hebben zowel Hanneke als ik enorm veel voordeel gehad.

Hierna kwam er werk aan de winkel voor de laboranten van het influenzacentrum te Rotterdam. Ik kan me voorstellen dat na 7 maanden titreren, eieren bebroeden, enzovoorts, een zucht van verlichting opging. Achteraf bezien had ik met die hitte wel eens vaker een ijstaart voor jullie kunnen bestellen.

Karin was mijn research assistent. Met bewondering heb ik mogen constateren dat alle data door jou bewerkt werden tot voor mij begrijpelijke en bruikbare gegevens. Het was jou nooit teveel, ook al wilde ik de gevens liever gisteren dan vandaag. Het feit dat je alle bewerkingen niet een, maar meerdere malen zeer zorgvuldig controleerde gaf mij het gerustellende gevoel dat hetgeen van jouw bureau kwam betrouwbaar was. Je verzoek indertijd aan dit onderzoek mee te mogen werken om zodoende je wetenschappelijke kennis te verruimen, heeft zijn vruchten afgeworpen.

Nic en Marc; aanvankelijk schoorvoetend, later vol enthousiasme, hebben jullie meegewerkt aan dit onderzoek. Nic, jij was degene die mij attendeerde op het onderzoekdesign. Het is voor mij een bijzondere eer een van de laatste promovendi te mogen zijn bij de nestor van het influenza-onderzoek in Nederland. Ik ben blij jou te hebben leren kennen. Marc, jij was steeds nadrukkelijk aanwezig. Mede dank zij jouw niet onaanzienlijke inbreng zijn de hoofdstukken 10, 11 en 12 geworden tot wat zij nu zijn; artikelen die in gerenommeerde medische tijdschriften worden opgenomen. Carel, jouw epidemiologische kennis konden wij niet ontberen. Zowel in de opzet van het totale onderzoek als in de verdere analyses, met name bij hoofdstuk 12 , had jij een waardevolle inbreng.

Van André en Geert-Jan weet ik niet wie en wat ik het eerst moet noemen. Geert-Jan, het was een gouden greep jou te vragen in onze praktijk te. komen werken toen onze praktijk een academiserings-overeenkomst met de universiteit aanging. Behalve een heel plezierige collega was je katalysator van het wetenschappelijke gebeuren in enze praktijk. Van jou heb ik geleerd een artikel op wetenschappelijk verantwoorde manier te schrijven. Een hoofdstuk dat niet goed liep wist jij op subtiele wijze om te bouwen. Jouw kennis was voor mij een gemakkelijke toegankelijke informatiebron, Geert-Jan ik heb veel van je geleerd en hoop op een nog lange samenwerking.

André, jij was degene, die mij op het idee bracht van dit onderzoek. Op je bekende vriendelijke manier weet je een vraag zo indirect te formuleren dat een argeloos iemand de importantie van de vraag niet direct in de gaten heeft. Het is je weer gelukt en ik ben er niet rouwig om. De wijze waarop jij mij, eigenlijk Geert-Jan en mij, gesteund hebt, was voortreffelijk. Wanneer we dachten klaar te zijn met een onderwerp had jij toch nog de nodige kritische opmerkingen al was het 's nachts om half twee. De regressie-analyses, in deze studie gebruikt, waren jouw idee. Af en toe verkeerde ik in de waan je enige promovendus te zijn. Een betere promotor had ik mij niet kunnen wensen!

Onze kinderen hebben dit alles van een veilige afstand aanschouwd. $\mathrm{Pa}$ en Ma zijn weer 
bezig onder toeziend oog van de hond Cartouche. Jullie belangstelling en begrip was een grote stimulans voor ons enthousiasme.

Tot slot Hanneke. Jij was degene die direct enthousiast was over dit promotie-onderzoek. Samen hebben wij dit gedaan. Het was jouw verdienste dat vaccinatie en bloedafname bij alle deelnemers organisatorisch vlekkeloos verliep. De wijze waarop jij al mijn gekrabbel en tabellen tot fraaie manuscripten hebt omgetoverd was een enorm gemak en tijdbesparing. In deze 3 jaren ben je een influenzadeskundige geworden. En daarnaast bleef het huishouden en de praktijk gewoon doorlopen. Na deze 3 tropenjaren zullen we onze sociale contacten weer oppakken.

Een ieder hier genoemd hebbende, dank voor jullie inbreng. 


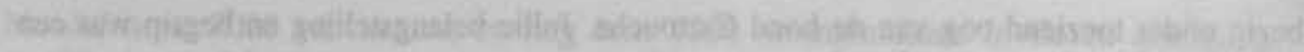

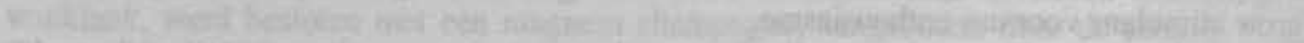

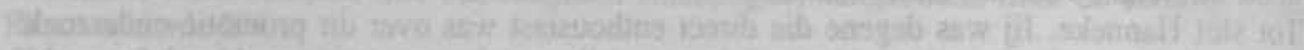

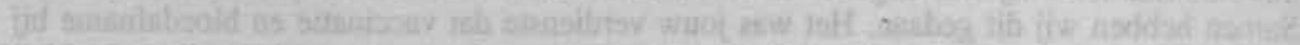

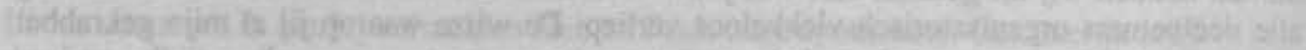

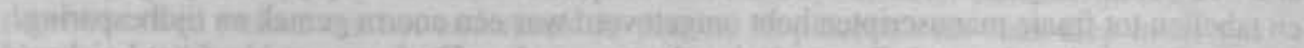

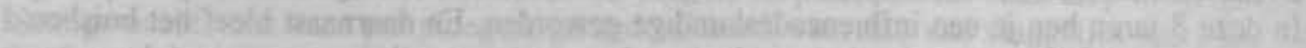

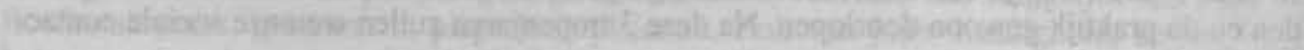

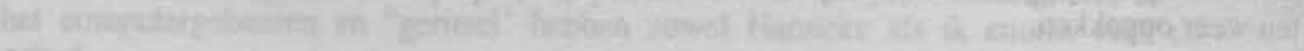
ditiritat

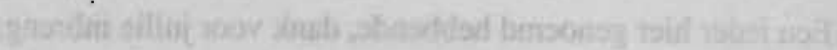

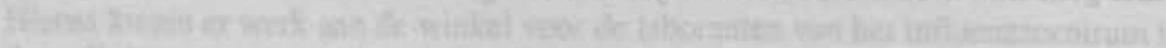

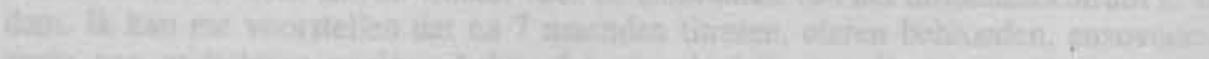

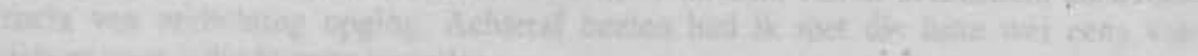

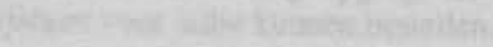

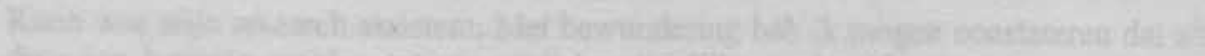

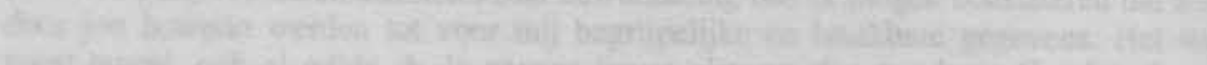

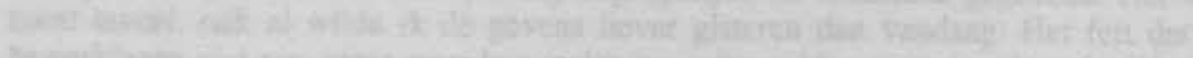
Whaty

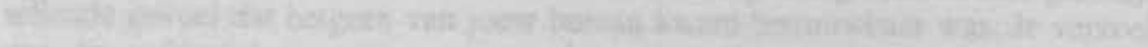

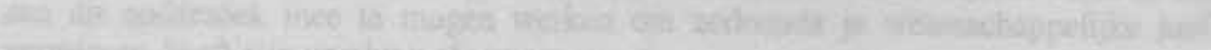

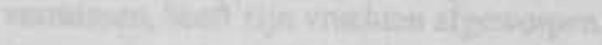

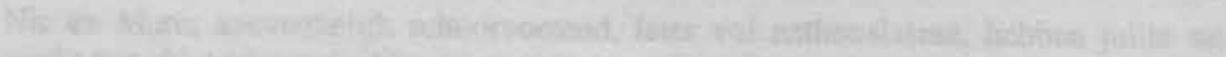

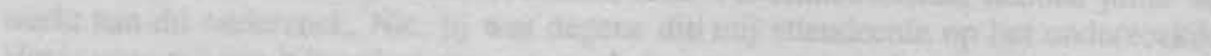

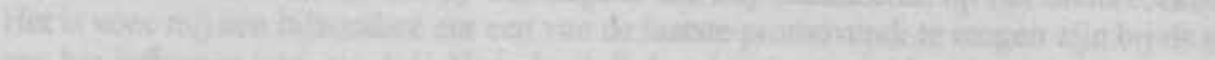

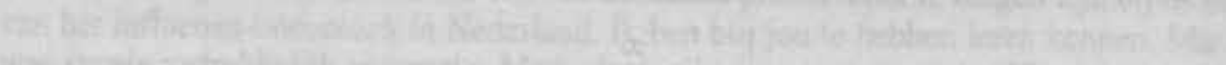

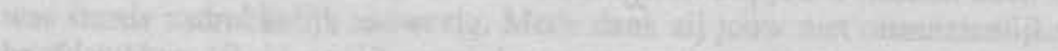

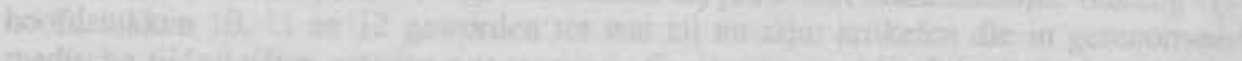

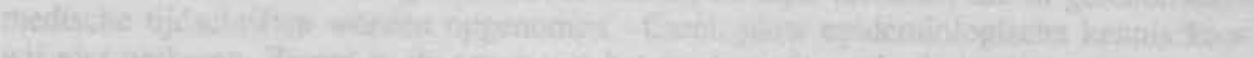

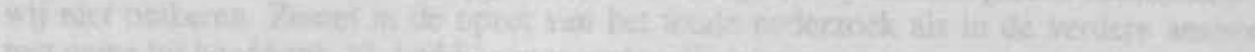

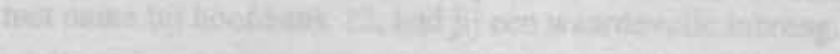

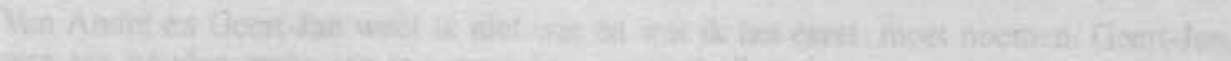

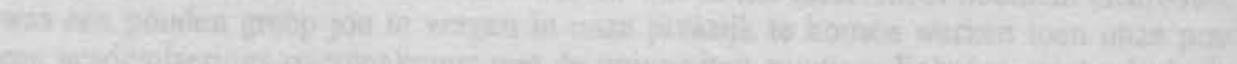

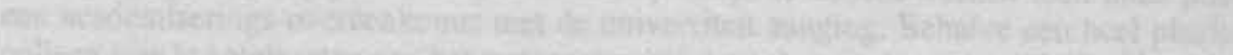

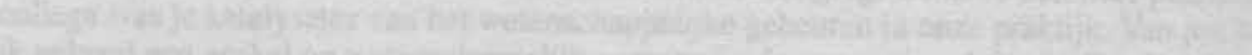
4.

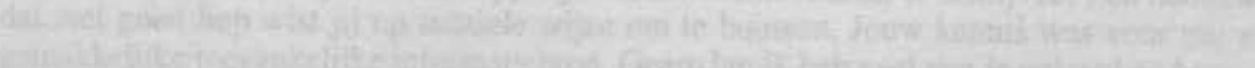

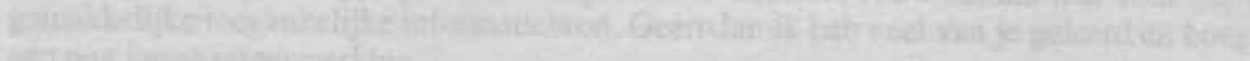

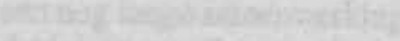

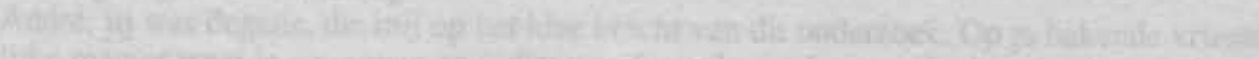

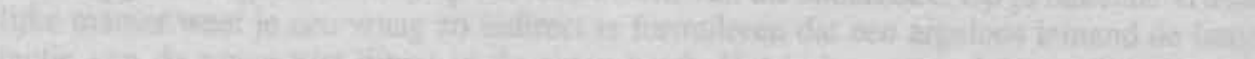

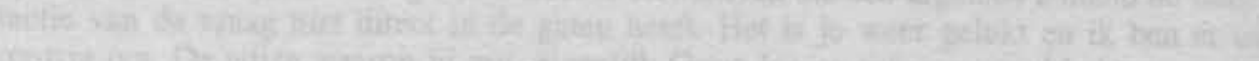

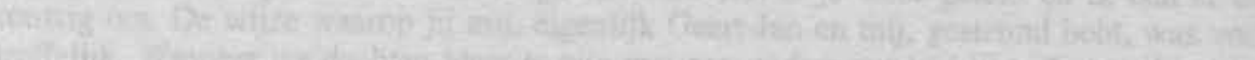

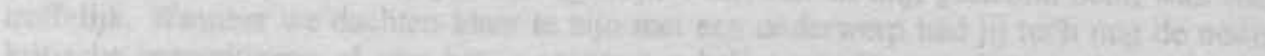

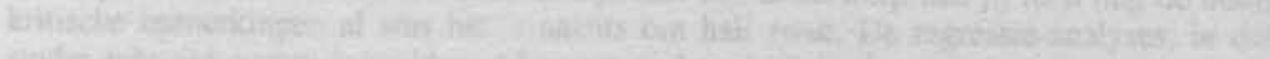

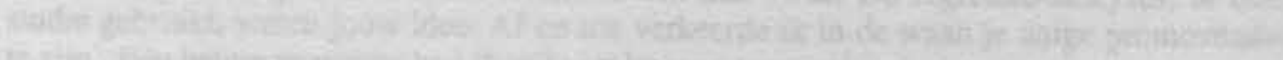

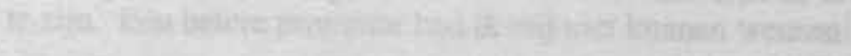

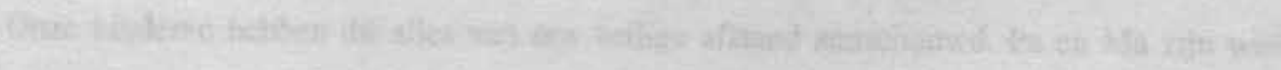




\section{CURRICULUM VITAE}

Govaert, Theophile, Marie, Eduard, werd geboren te Stein (Lb) 11 September 1931. Hij behaalde in 1951 het diploma gymnasium B, waarna hij gedurende twee jaar zijn dienstplicht vervulde als artillerie officier. In 1953 begon hij zijn studie medicijnen te Leiden alwaar hij in 1961 zijn artsdiploma behaalde. Hierna werkte hij driekwart jaar als algemeenen interne-assistent in het ziekenhuis te Hilversum. Hij vestigde zich als apotheekhoudend huisarts op 1 october 1961 te Stein in associatie met zijn vader Dr A.A.J. Govaert. Vanaf 1963 werkte hij als solist in deze praktijk waarna hij in 1971 een associatie aanging met zijn huidige associé, R.M.F.M. Leclercq. Vanaf de oprichting van de universiteit te Maastricht werkten beide collegae samen met de medische faculteit hetgeen resulteerde in een academiseringsovereenkomst in 1988.

Naast enkele bestuurlijke functies in tennis- en hockey-verenigingen was Govaert voorzitter van de nascholingscommissie Limburg voor huisartsen in de jaren 1966-1974, lid en voorzitter van het bestuur van het centrum voor maatschappelijke dienstverlening Westelijke Mijnstreek, lid van de vestigingscommissie voor huisartsen Westelijke Mijnstreek, medisch adviseur van het Groene Kruis te Stein en medisch adviseur van het kloosterbejaardenoord te Stein. 


\section{Influenza bij ouderen}

Een onderzoek naar huisartsgeneeskundig belangrijke parameters voor de diagnostiek van en het vaccinatiebeleid bij influenza.

\section{Th.M.E. Govaert}

Van de sterfte tengevolge van influenza valt $95 \%$ binnen de leeftijdsgroep van 60 jaar en ouder. Desondanks laait ieder najaar de discussie op of influenzavaccinatie wenselijk is. Bij ouderen zou het immunologisch apparaat minder werkzaam zijn waardoor vaccinatie minder effectief kan zijn. Bovendien is men beducht voor bijwerkingen van vaccinatie.

Middels een gerandomiseerde, dubbelblinde, placebo-gecontroleerde studie onder 1838 patiënten van 60 jaar en ouder zijn de effectiviteit, immuunrespons en bijwerkingen van influenzavaccinatie onderzocht. Tevens werden de voorspellende waarde van symptomen, de ziekteduur tengevolge van influenza, de vaccinatiegraad en de incidentie van influenza en influenza-achtige ziekten bestudeerd.

Th.M.E. Govaert studeerde medicijnen aan de Rijksuniversiteit van Leiden en werkt sinds 1961 als huisarts in Zuid-Limburg. Sedert 1981 is hij tevens verbonden als medewerker aan de Vakgroep Huisartsgeneeskinde van de Rijksuniversiteit Limburg.

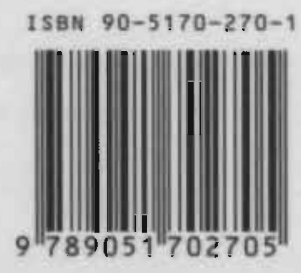

